
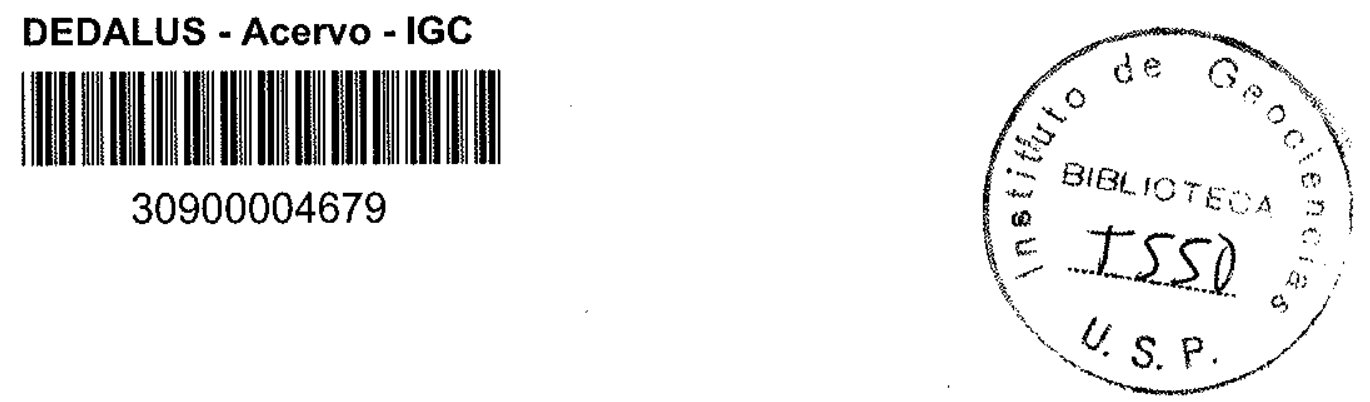

\title{
PROPRIEDADES GEOTÉCNICAS E COMPORTAMENTO TECNOLÓGICO DE ARENITOS DA FORMAÇÃO CAIUÁ
}

JAYME DE OLIVEIRA CAMPOS

Tese apresentada ao Instituto de Geociências da Universidade de São Paulo como requisito a obtenção do título de Doutor

Orientador:

Dr. José Eduardo Siqueira Farjallat 


\section{ERRATA}

Pägina 8

1․ parågrafo, 15 - linha: onde se lê "...por volta de $50^{\circ}$...", leia-se "...por volta de $50 \mathrm{~kg} / \mathrm{cm}^{2}$...".

Pägina 19 .

1ํㅡ linha: onde se lê "...fazendo...", leia-se "...jazendo...",

Pägina 25

29 parägrafo, 4ํ linha: onde se lê ",..com cimentos não ćarbonäti cos...", leia-se "...com cimentos limonitico e limonitico/carbonätico...".

Pägina 47

3ํㅡㅁömula: ao invës de "ras", leia-se "rs".

Pägina 59

1ํ förmula: ao invës de $" \zeta \neq c+\sigma+t g \phi^{\prime \prime}, \quad$ leia-se

$" \zeta=c+\sigma \cdot \operatorname{tg} \phi^{\prime \prime}$.

Pägina 90

Tabela 7: onde se lê: "rs $\left(\mathrm{g} / \mathrm{cm}^{3}\right)$ ", leia-se "ras $\left(\mathrm{g} / \mathrm{cm}^{3}\right)$ ".

Pägina 106

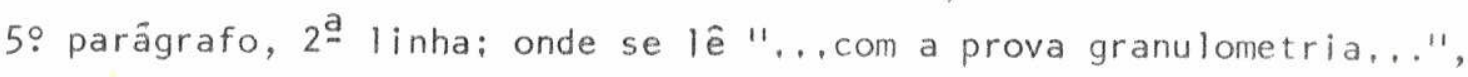
leia-se "...com a nova granulometria...".

Pägina 142

19. parägrafo, 6a linha: onde se lê "...parentemente...", leia-se ". ., aparentemente...". 
Pägina 150, 50 parägrafo, 4a linha; päglna 173, 19 parágrafo, 2 a linha; pägina 207, 19 parägrafo, 5 a llinha; e päglna 222, 19 parägrafo, 5 a linha: onde se lê "...excessões...", lela-se "...exceções...".

Pägina 173

4? parägrafo, 1ㅁ linha; onde se lê "e) ...ensalos...", leia-se "e) ...amostras...".

Pägina 180

4: parägrafo, 1 Iinha: onde se lê "...da ordem de $25 \mathrm{~kg} / \mathrm{min} .$. .", leia-se "...da ordem de $25 \mathrm{~kg} / \mathrm{cm}^{2} / \mathrm{min} . . . "$.

Pägina 189

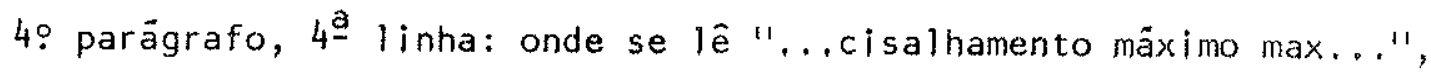
leia-se "...cisalhamento mäxima $\zeta$ max...".

Pägina 192

29 parägrafo, 5- linha: onde se lê "...deteoriração...", leiamse "...deterioração...".

Pägina 198

1\% parägrafo, 8 a linha: onde se lê "...os valores mäximos de $E$, são...", leia-se "..os valores mãximos e mínimos de E, são...".

Pägina 202 e 203

60 parägrafo, 3 a linha; e 19 parägrafo, 4 a linha, respectivamente: onde se lê "...os nödulos...", leiause "os mödulos...".

Pägina 204

60 parägrafo, 4a linha: a palavra d'ägua foi separada indevidamente, sendo que o correto seria a separação da 1 ạ silaba "d'â" do restante da palavra. 
Pägina 210

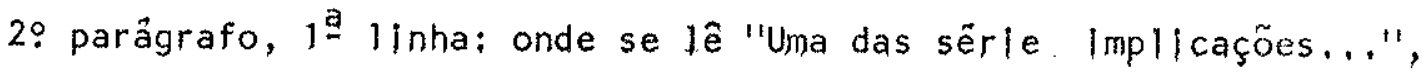
lela-se "Uma das sërlas Impll cações...".

Pägina 210

6: parägrafo, 3a linha: onde se le "..quando á colocação..." le la-se "...quanto à colocação...".

Pägina 213

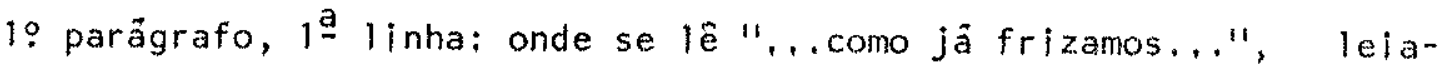
-se "... como jã se frizou...".

Pägina 216

119 parägrafo, 1̊ Ilnha: onde se lê "...Farran $\varepsilon$ Thënoz ( ), .," leia-se "...Farran \& Thẻnoz (1965),...".

Pägina 217

1ํ parăgrafo, 9 a linha: onde se lê "...que fundirão...", lela-se ".. que fendilharão...".

Pägina 219

39 parăgrafo, 4a linha: onde se lé "Esclarece que for desenvolvido...", leia-se "Esclarece que fol desenvolvido...".

Pägina 225

29 parägrafo, 3 a linha: onde se lê "...tabelas nümeros 55 e 56 . Adotar-se,.,", leia-se "...tabelas nümeros 55 e 56 , adotar-se...".

Pägina 226

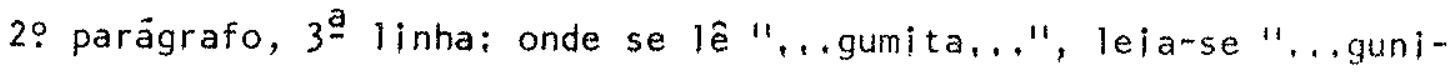
ta...". 
Pägina 226

A frase "- Cambotas metälicas em geral con chapas de blindagem nas calotas.", ẽ seguida pela frase "A escolha da sustentação serä tambëm influenciada pelas condições do lençol freätico e pelas velocidades de percolação da ägua por ocaslão das escavações.", e por "Maclços da cate goria VI "e seus tipos especificos de revestimento, aos quais deve ser. acrescido: "Chapas metâllicas ou blindagens sobre cambotas metálicas (com ou sem aplicação ulterior de uma camada de gunita.)". Apös, segue-se "Ao se adotar as ponderações..... quanto a tais utillizaçōes: ",alëm dos ítens 1), 2) e 3) da pägina 226 e o todo e conteudo da pägina 227.

\section{Pägina 227}

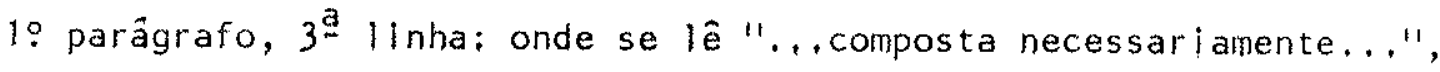
leia-se "... comporta necessariamente...".

Pägina 230

2: parägrafo, 1 a linha; onde se lê "O esforço resistente vale $R=$ $A, "$ leia-se "O esforço resistente vale $R=G$. A,".

Pägina 235

2ㅇ parägrafo, 8 linha: onde se lê "...Barros, 1969). Ter-se-à...", leia-se "...Barros, 1969), ter-se-ã...".

Pãgina 236

2: parägrafo, $3^{a}$ linha: onde se lê $" . .$. sendo,...", leia-se $" . .$. senso...".

Pägina 240

$7^{a}$ referência: onde se lêe ". . Avifield". Lela-se "...Airfield".

Pägina 239

1ํ referência: onde se lê "Bagolini, Bernando...", leia-se "Bagolini, Bernardo...". 


\section{Acrescidas as referênclas:}

Oliveira, J.E, de, E Caruso, L,G. Caracterização tecnolöglca de rochas sedimentares clmentadas por öxido de ferro. Atas do $2 \%$ Simpösio Regio nal de Geologla, Vol. 2, Rlo Claro, nov, 1.979.

Robert, A, Oarenito Caiuä como base establlizada para fins rodoviärios Tese de concurso à Cảtedra de Estradas de Ferro e de Rodagem da Escom la de Engenharia da Universidade do Paranä, 1,956.

Souza, Antonio C.G, de \& Ferraz, Antonio C,P. Algumas consideraçōes sobre a possibilidade de utillização da laterita no Maranhão com agregado na composição de concretos - Seminärio da disciplina de pösugradua ção - Materiais de Construção - Escola de Engenharia de São Carlos, USP. 


\section{Figura 63}

Variações de parâmetros geomecânicos para solos e rochas

(Rocha, 1977)

a) Mỏdulo de Deformabllidade

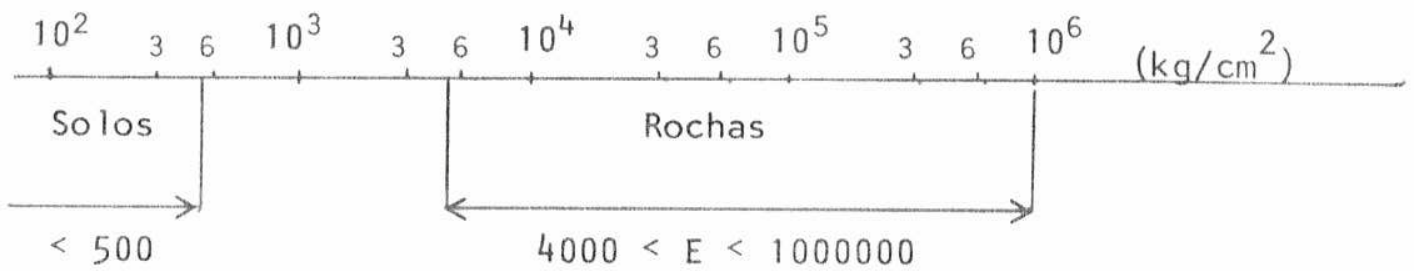

b) Coesão

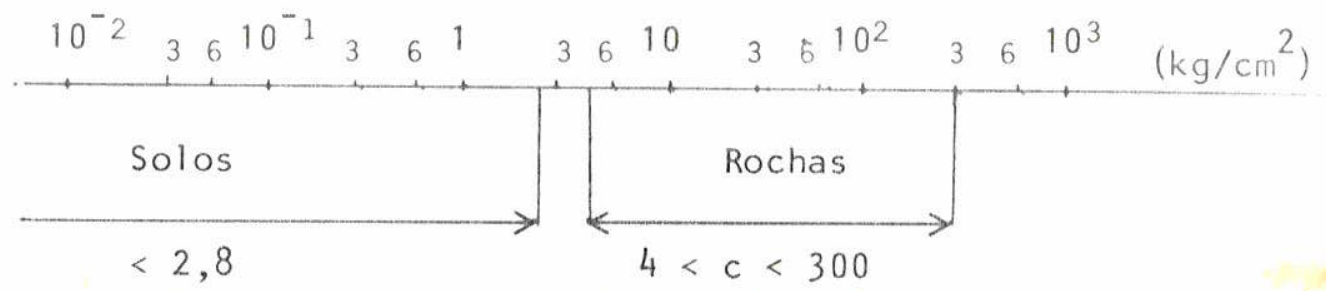

c) Ångulo de Atrito

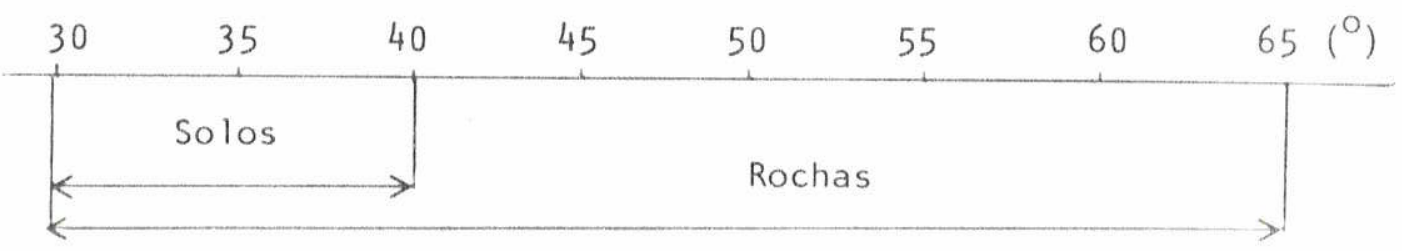

d) Resistência à Compressão Uniaxial

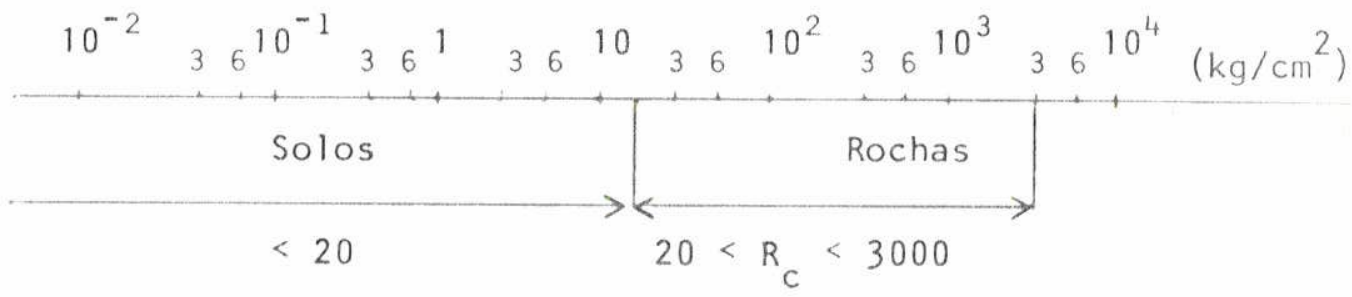



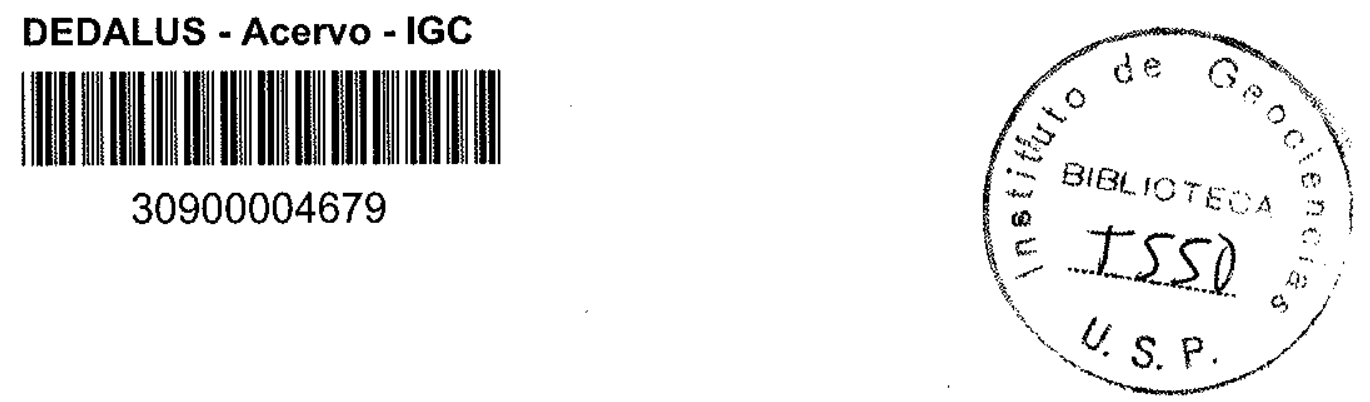

\section{PROPRIEDADES GEOTÉCNICAS E COMPORTAMENTO TECNOLÓGICO DE ARENITOS DA FORMAÇÃO CAIUÁ}

JAYME DE OLIVEIRA CAMPOS

Tese apresentada ao Instituto de Geociências da Universidade de São Paulo como requisito a obtenção do título de Doutor

Orientador:

Dr. José Eduardo Siqueira Farjallat 


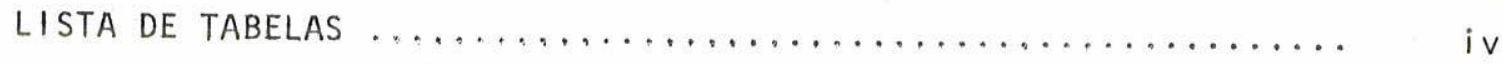

LISTA DE QUADROS $\ldots \ldots \ldots \ldots \ldots \ldots \ldots \ldots \ldots \ldots \ldots \ldots \ldots \ldots \ldots \ldots \ldots \ldots \ldots$

LISTA DE FIGURAS $\ldots \ldots \ldots \ldots \ldots \ldots \ldots \ldots \ldots \ldots \ldots \ldots \ldots \ldots \ldots \ldots \ldots \ldots \ldots \ldots \ldots \ldots$

LISTA DE FOTOS $\ldots \ldots \ldots \ldots \ldots \ldots \ldots \ldots \ldots \ldots \ldots \ldots \ldots \ldots \ldots \ldots \ldots \ldots \ldots \ldots \ldots$

Capítulo

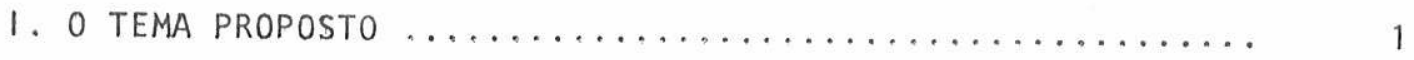

Introdução 1

Objetivos do Estudo 2

Estado da arte 3

$\begin{array}{ll}\text { Indicações do caminho a seguir } & 11\end{array}$

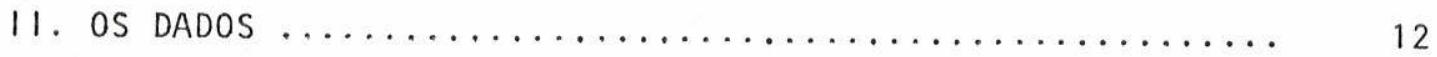

A Formação Caiuã no Pontal do Paranapanema 12

$\begin{array}{ll}\text { Introdução } & 12\end{array}$

Considerações sobre as ocorrências 13

Parâmetros estatísticos a partir das curvas cumulativas 17

$\begin{array}{ll}\text { Arredondamento } & 18\end{array}$

$\begin{array}{ll}\text { Textura superficial } & 18\end{array}$

$\begin{array}{ll}\text { Estruturas sedimentares } & 18\end{array}$

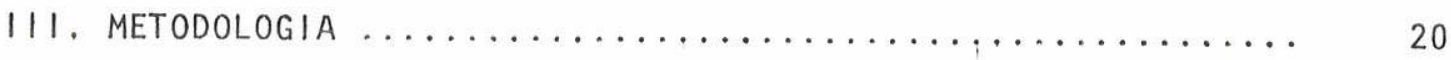

Exame da bibliografia existente $\quad 20$

Viagem ao campo e coleta de amostras $\quad 20$

Sistemätica para a caracterização das amostras 22

Ensaios, testes e estudos 26

Estudos petrogräficos - Seções delgadas $\quad 40$

Ensaios físicos 43 
Pägina

Granulometria 43

Densidade dos grãos 45

Massa especifica aparente seca 46

Absorçào d'ảgua 46

Porosidade aparente $\quad 47$

$\begin{array}{ll}\text { Porosidade real } & 47\end{array}$

Porcentagem de saturação de vazios 48

Ensaios de durabilidade $\quad 48$

A durabilidade de rochas $\quad 48$

Testes de durabilidade $\quad 50$

Ensaios mecânicos $\quad 51$

Resistência ao impacto Treton 51

Resistência à abrasão Los Angeles 54

Ensaios de compressão simples axial e deformabilidade 54

Resisténcia ao cisalhamento - compressão triaxial 57

Permeabilidade $\quad 60$

IV. APRESENTAÇÃO E INTERPRETAÇÃO DOS RESULTADOS $\ldots \ldots \ldots \ldots . . \ldots 3$

Questões relacionadas à Mineralogia e Petrografia 63

Granulometria $\quad 81$

Densidade dos grãos $\quad 81$

Massa especifica aparente seca $\quad 81$

Absorção d'ägua 94

Porosidade aparente $\quad 97$

$\begin{array}{ll}\text { Porosidade real } & 101\end{array}$

Porcentagem de saturação dos vazios 102

$\begin{array}{ll}\text { Ensaios de durabilidade } & 106\end{array}$

Ciclagem natural 106

$\begin{array}{ll}\text { Ciclagem ägua-estufa } & 106\end{array}$

Considerações sobre os ensalos de ciclagem 132

Ensaios mecânicos 133

Resistência ao Impacto Treton 133

Considerações relativas aos ensaios de resistência ao impacto Treton 139

Resistência à Abrasão Los Angeles 140

Comentärios sobre os ensalos de Abrasão Los Angeles 141

Ensaios de compressão axial e deformabilidade 142 
Pāgina Comentärios quanto à compressão simples e deformabilida
de

143

Ensaios triaxiais com os Arenitos Caiua

Conslderações sobre os ensalos triaxiais

189

Ensaios de permeabilidade com o Arenito Caiuä

192

V. REFLEXÕES QUANTO A APLICAÇÃO DOS ARENITOS CAIUA ........

Notas relativas à rotulação geotëcnica dos arenitos em questão

Aplicabilidade como fundação

Perfurabilidade dos Arenitos Caiuá

Aplicabilidade como enrocamentos

Critêrios gerais para a escolha dos materiais naturais

Enrocamentos

208

"Rip-raps"

212

Considerações sobre algumas especificações construtivas

Aplicação como agregado para concreto

Utilização em obras rodoviärias

218

Utilização em escavações subterrâneas

Taludes em Arenitos Caiuá

Conclusões e recomentações finais

REFERENCIAS BIBLIOGRAFICAS $\ldots \ldots \ldots \ldots \ldots \ldots \ldots \ldots \ldots \ldots \ldots \ldots \ldots$ 
LISTA DE TABELAS

Tabela

Pägina

1. Graus de coerência de rochas

2. Atitudes do diaclasamento no Arenito Caiuã, local de a mostragem $\mid 1 \ldots \ldots \ldots \ldots \ldots \ldots \ldots \ldots \ldots \ldots \ldots \ldots \ldots$

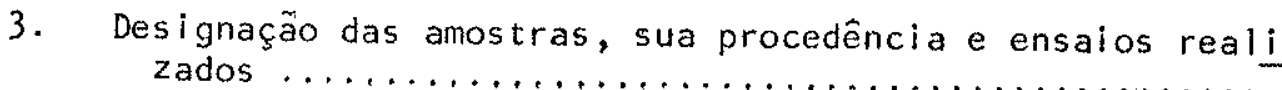

4. Sërie de peneiras empregadas no peneiramento da fração grossa do solo ..................................................

5. Percentagens das frações grossas e finas em amostras dos

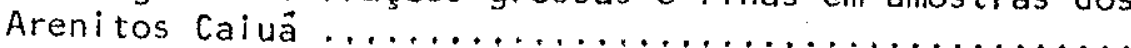

6. Densidade dos grãos dos Arenitos Caiuä

7. Massa específica aparente seca dos Arenitos Caiuä ..... 90

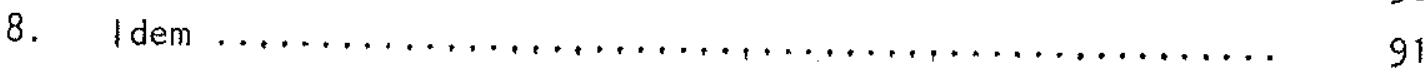

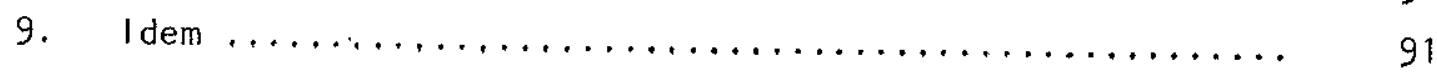

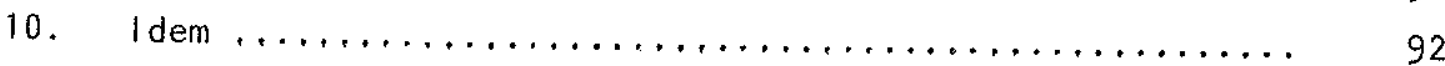

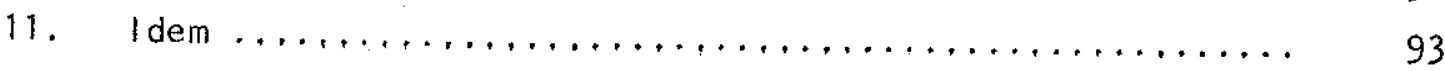

12. Valores da absorção d'ägua nos Arenitos Caiuä ......... 94

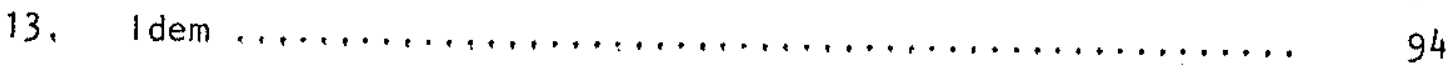

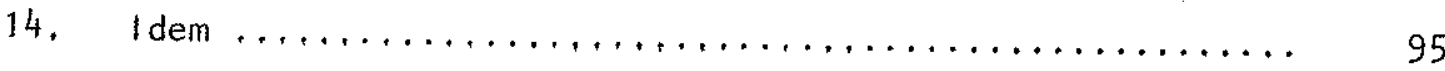

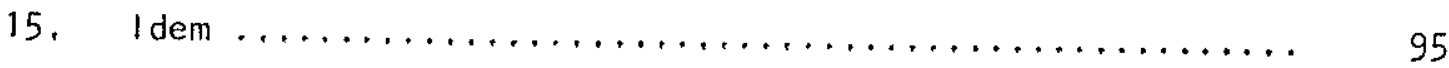

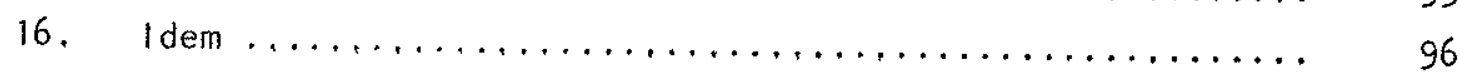

17. Valores da porosidade aparente dos Arenitos Caiuä ..... 97

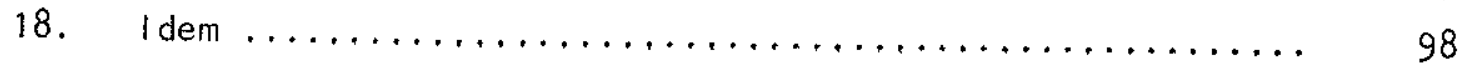

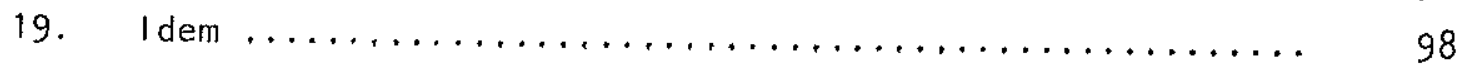

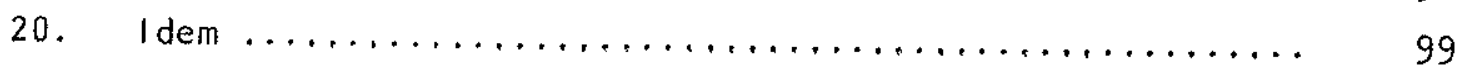

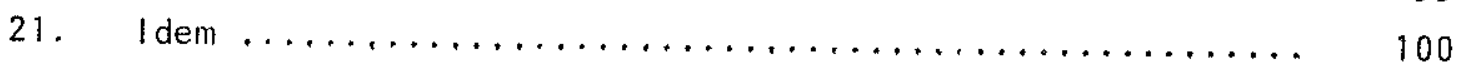

22. Porosidade real dos Arenitos Caiuã ................. 101

23. Percentagem de saturação dos vazios dos Arenitos Caiuã . 102

24. Valores comparativos das propriedades físicas dos Areni

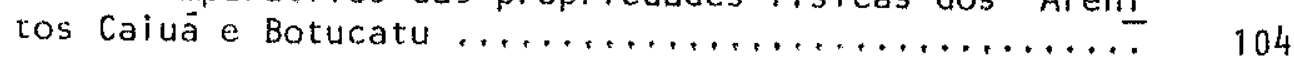

25. Minerais pesados (em \%) no Arenito Caiua ........... 105

26. Ciclagem natural com os Arenitos Caiua ............. 108

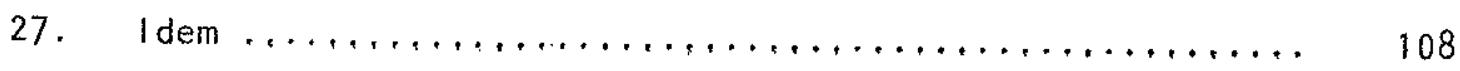


Tabela

Pägina

28. Ciclagem ägua-estufa com os Arenitos Caluä ........... 109

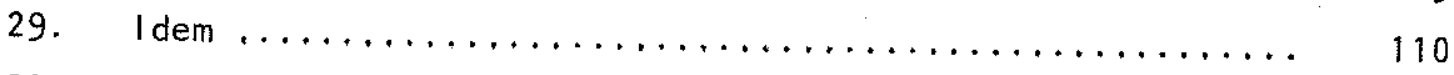

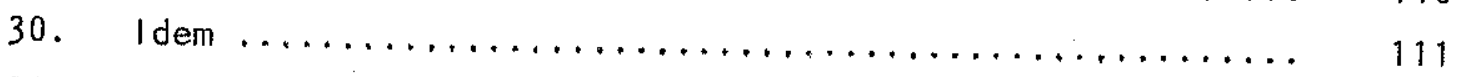

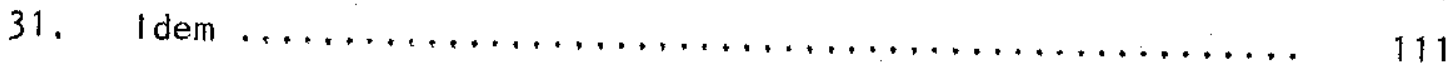

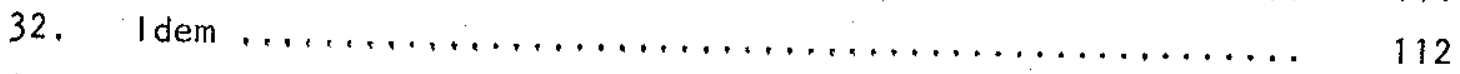

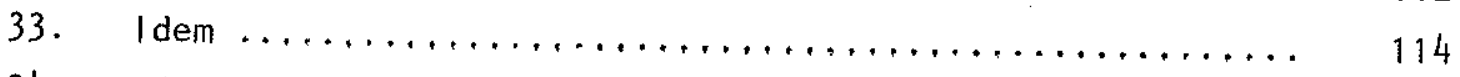

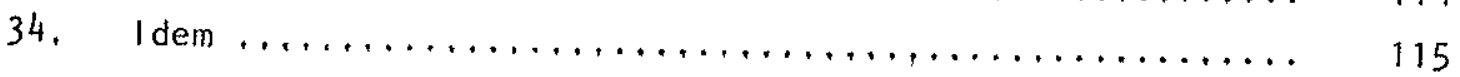

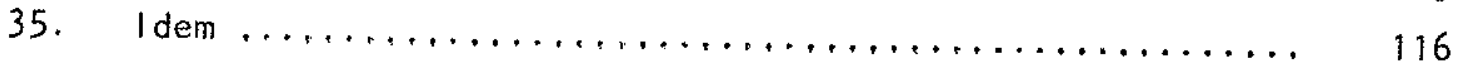

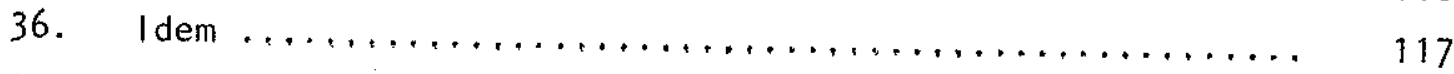

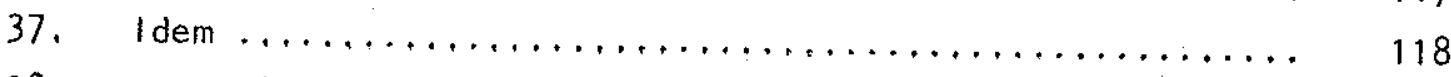

38. Resistência ao impacto Treton com os Arenitos Caiuã .... 134

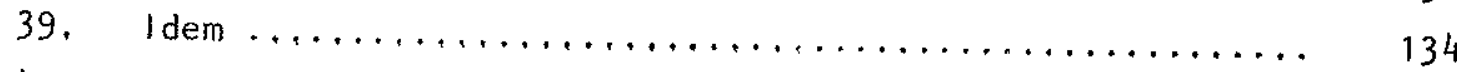

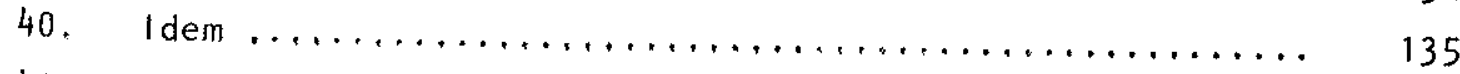

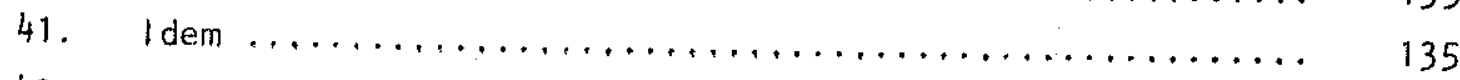

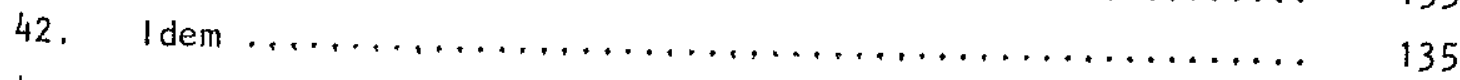

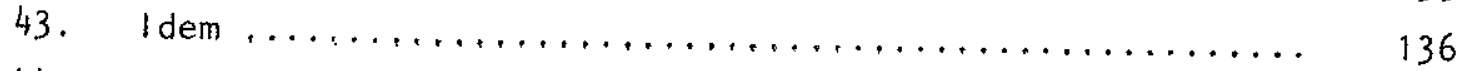

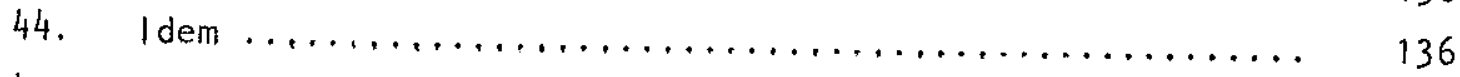

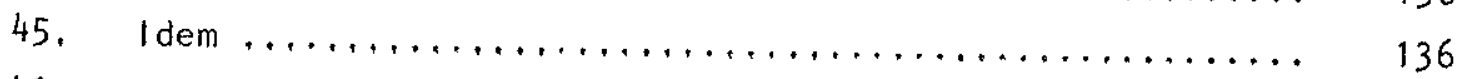

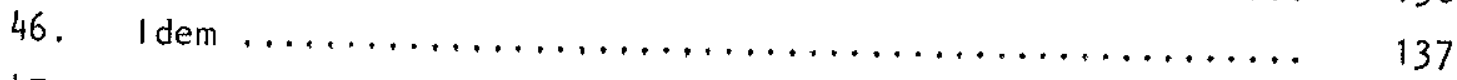

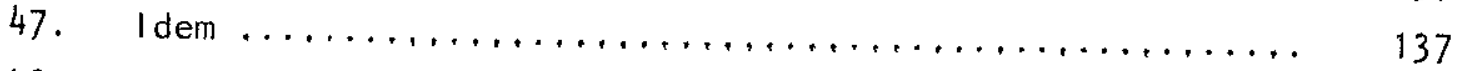

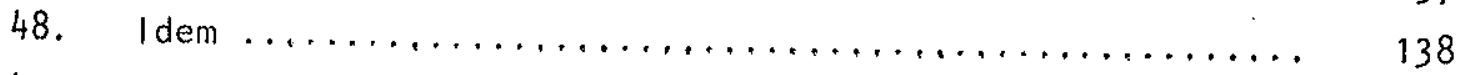

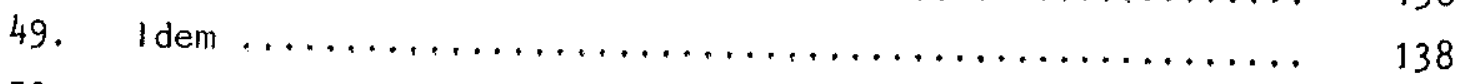

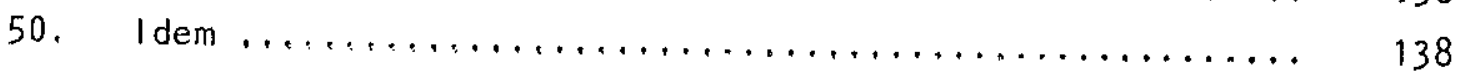

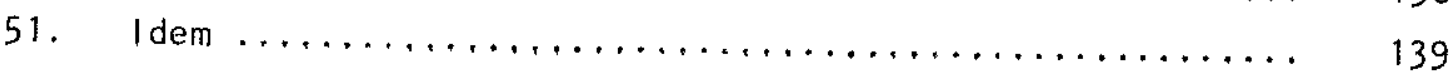

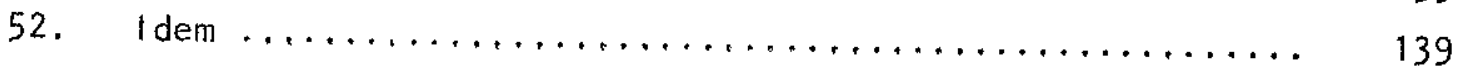

53. Resistência à abrasão Los Angeles do Arenito Caiuä ..... 140

54. Idem ................................. 141

55. Ensaios de compressão simples e deformabilidade, dados dos corpos de prova ensaiados ................... 144

56. Ensaios de compressão triaxiais - Indices físicos - Amos tras pertencentes ao Conjunto $1 \ldots \ldots \ldots \ldots \ldots \ldots \ldots \ldots$

57. Ensaios de compressão triaxiais - Amostras pertencentes

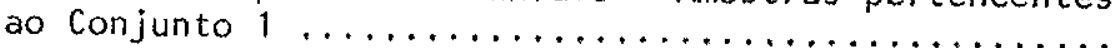

58. Ensaios de permeatilidade com os Arenitos Caiuä .......

59. Resistência ã compressão simples, mödulo de deformabilidade e resistêncía ao cisalhamento de solos e rochas. 197

60. Proposta para a graduação dos blocos em "rip-raps" ..... 212 
Tabela

Pägina

61. Carga de rocha $H_{\text {}}$ em metros de rocha sobre o suporte do teto do túnel, com largura $B$ metros, altura $H_{t}$ metros

e uma profundidade superior a $1,5\left(B+H_{t}\right) \ldots \ldots \ldots \ldots$

62. Fator de resistência mecânica para solos e rochas ..... 228 
LISTA DE QUADROS

Quadro

Pägina

1. Critërios para a descrição dos Arenitos Caiuä quanto ã

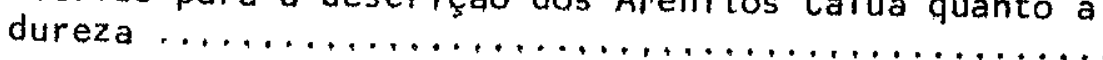

2. Relação nominal dos ensaios referidos na Tabela $2 \ldots$. 
Figura

Păgina

1. Mapa de localização dos pontos de amostragem ......... 21

2. Esquema da máquina de Impacto "Treton" $\ldots \ldots \ldots \ldots \ldots \ldots \ldots \ldots$

3. Esquema de um Extrator Soxhlet ................. 53

4. Esquema da mäquina Los Angeles ................. 55

5. Corte esquemätico de uma montagem para ensaio de Compres
são Simples Axial

6. Esquema da câmara para

7. Corte esquemätico de um permealos ..... 58

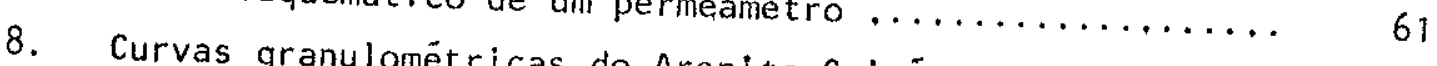

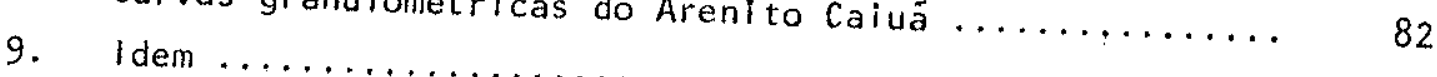

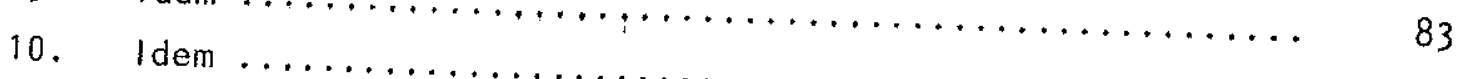

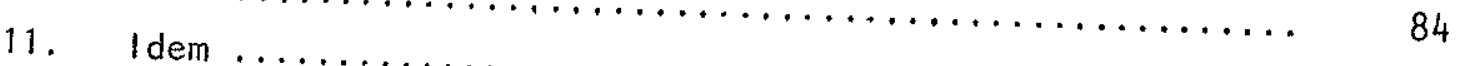

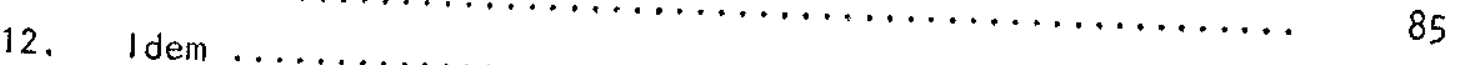

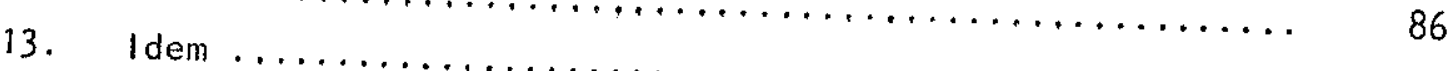

14. Ensaios de ciclagem natural

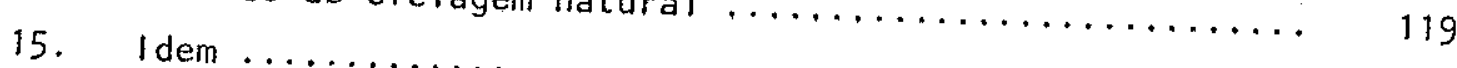

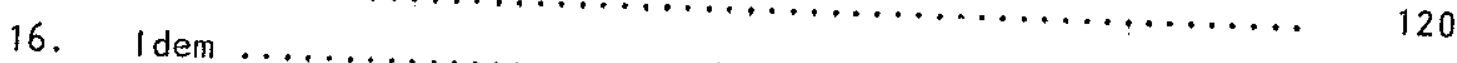

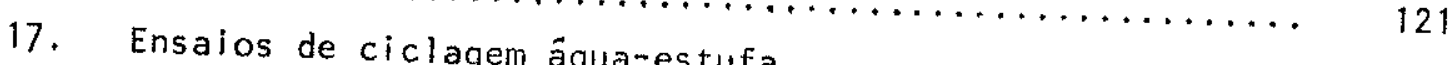

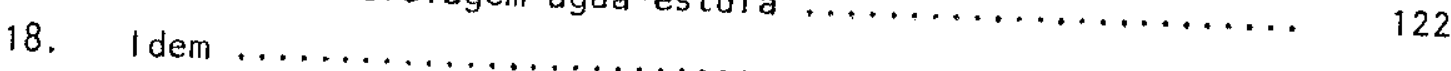

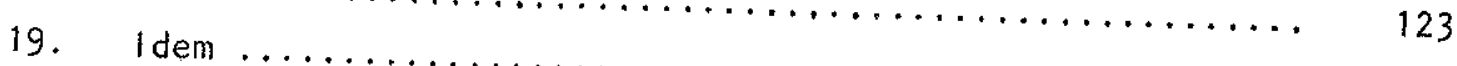

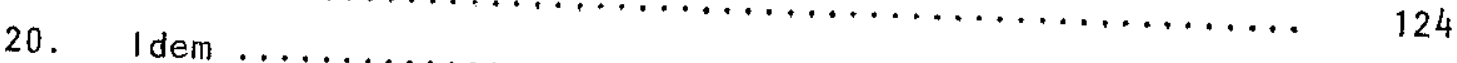

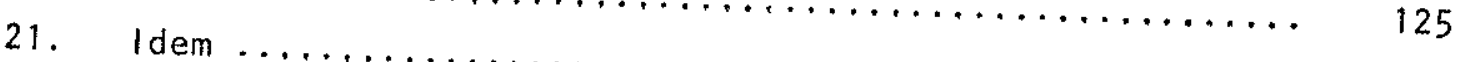

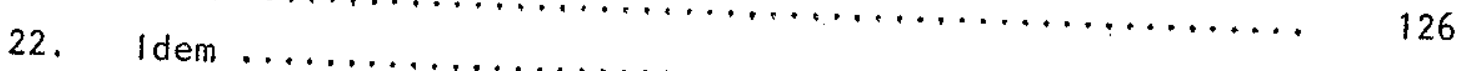

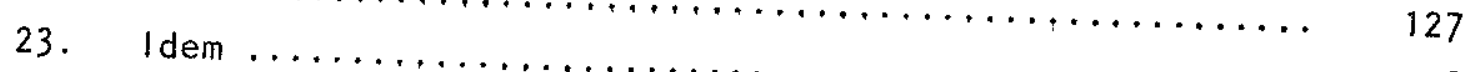

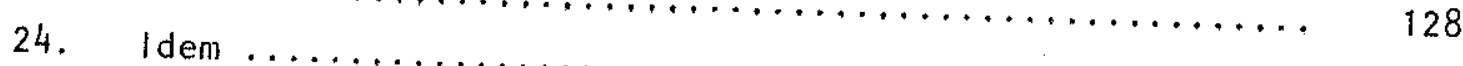

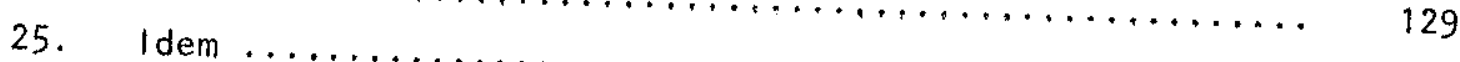

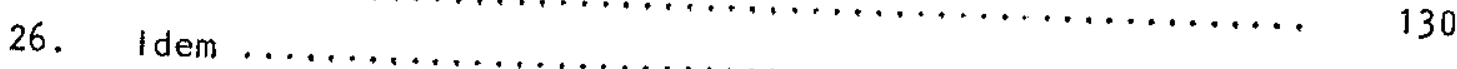

27. Curvas genëricas tensöes $x \quad \ldots \ldots \ldots \ldots \ldots \ldots \ldots$

(Seg. Mello Mendes, mod.) $x$ deformações, para rochas

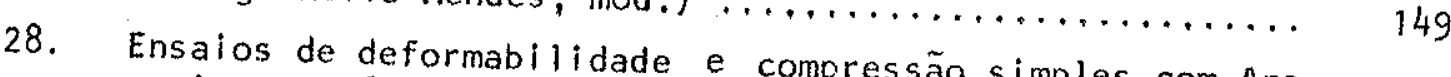

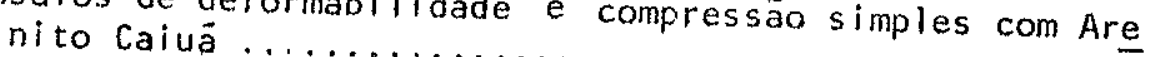

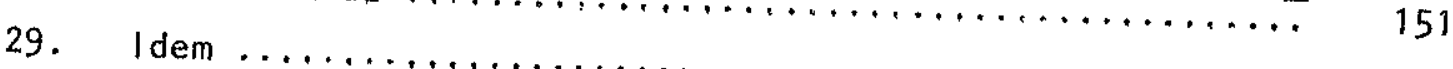


30. Idem

31. Idem

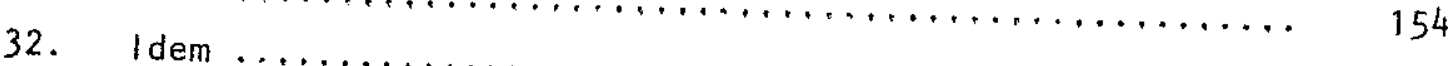

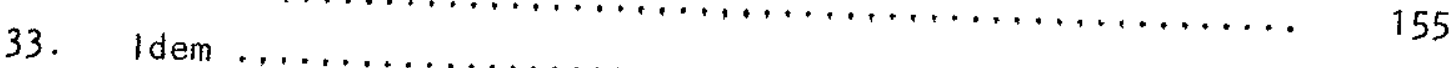

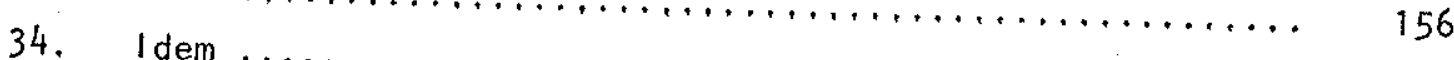

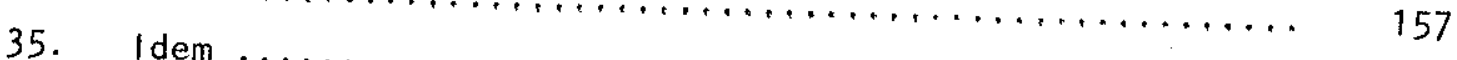

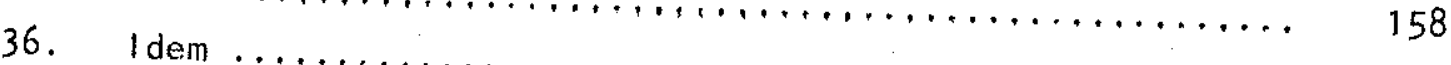

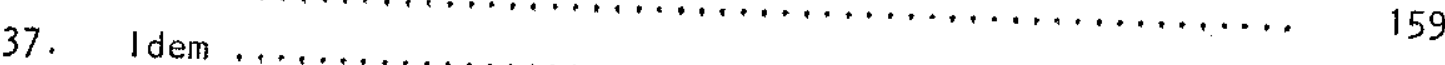

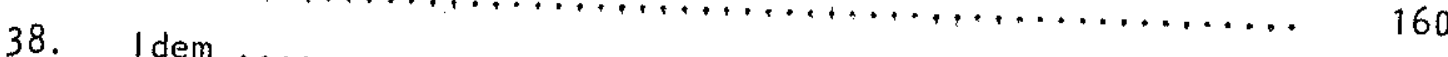

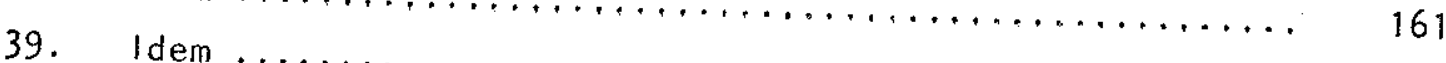

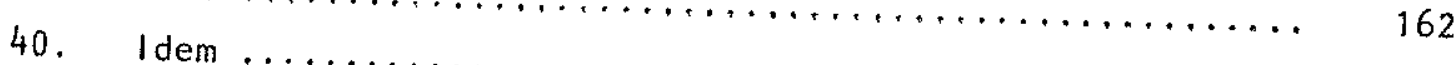

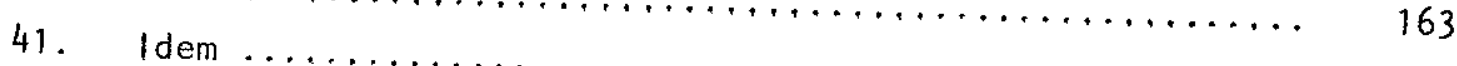

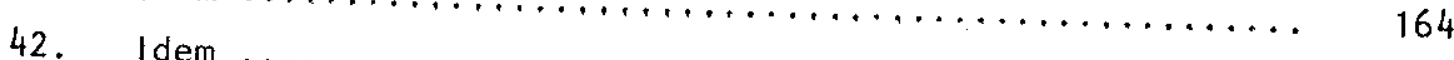

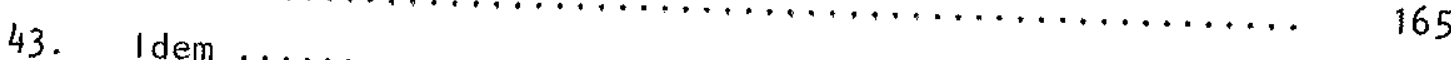

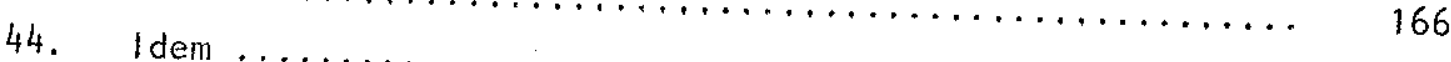

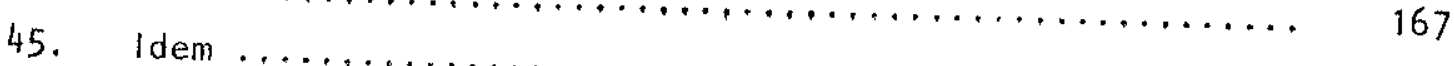

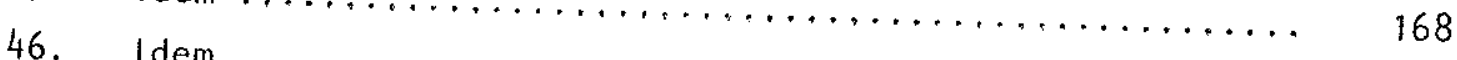

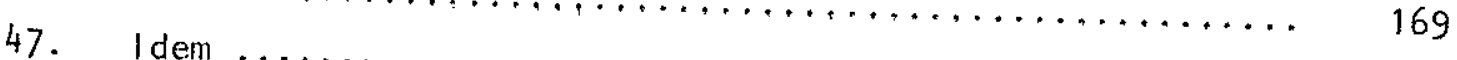

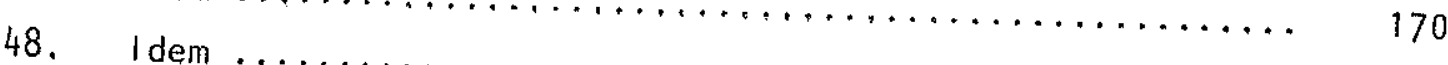

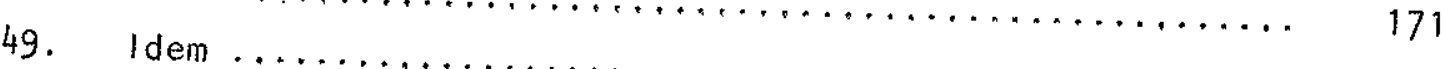

50. Correlação entre ras (massa especific a ruptura (orup) no enecifica aparente seca) e värios exemplares no ensaio de compressão simples para

51. Correlacão entre ras (massa .......................... $E_{4}$ (möulo de deformabilidade secante aparente seca) e $\mathrm{Kg}_{\mathrm{g}} 9 \mathrm{~cm}^{2}$ ) para värios exemplares secante para $\sigma=40$

52. Correlação entre a porosidade aparente $(\mathrm{Pa})$ e a ruptura no ensaio de compressão simples (orup) para värios e-

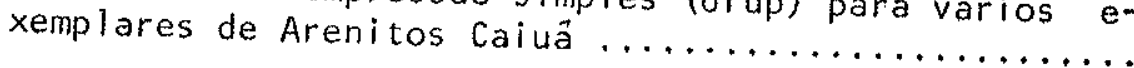

53. Correlação entre Pa (porosidade aparente) e E 40 (Mödulo da elasticidade secante) para $\sigma=40 \mathrm{Kg} / \mathrm{cm}^{2}$, para vä-

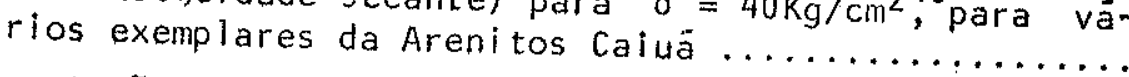

54. Correlação entre a absorção d'ägua (Ab) e a ruptura no ensaio de compressão simples (orup) para vários exem-

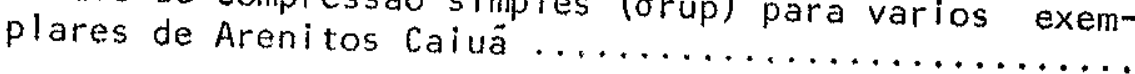

55. Correlação entre Ab (absorção d'ägua) e E 40 (mödulo de elasticidade secante) para os $40 \mathrm{Kg} / \mathrm{cm}^{2} 40$ para vários

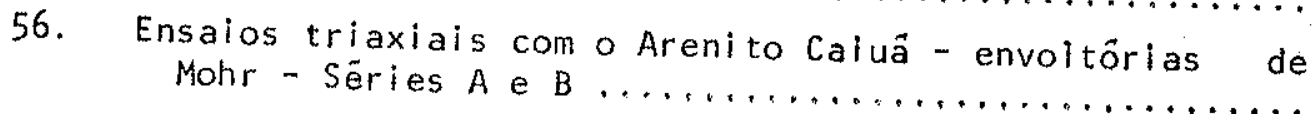

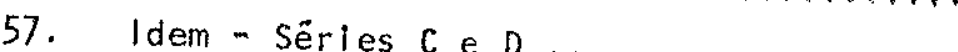


58. Ensalos triaxiais com o Arenito Caluä - curvas $\left(\sigma_{1}-\sigma_{3}\right)$ $x$ deformaçōes axiais especificas - Sëries $A$ e $B(\ldots$.

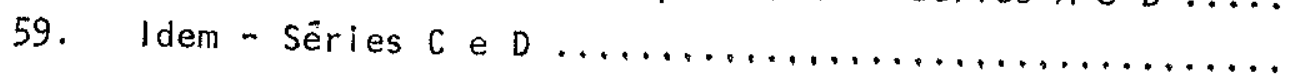

60. Comportamento frägil düctil e plästico de rochas, segundo valores crescentes com a diferença $\left(\sigma_{1}-\sigma_{3}\right) \ldots .$.

61. Correlação entre as resistências à compressão simples e à compressão puntiforme, com valores tipicos para as rochas mais comuns ...............................

62. Classificação de materiais rochosos, baseada na resistên cia à compressão slmples, Rc ................

63. Variações dos parâmetros geomecânicos para solos e ro-

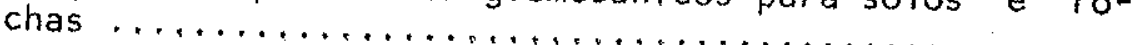

64. Classificação geotécnlca para rochas intactas ........ 201

65. Grau de influência da deformabilịdade ............. 203

66. Seção geológica no local da amostragem $|1|$, indicando a

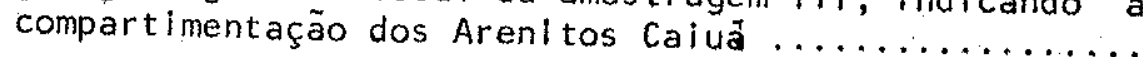

67. Mëtodo padrão para avaliar-se a adequabillidade de um material para "rip-rap" $\ldots \ldots \ldots \ldots \ldots \ldots \ldots \ldots \ldots \ldots \ldots . . \ldots 211$

68. Relação de forças na anälise de equilibrio-limite .... 231

69. Condições para a estabillidade de taludes em rochas estra tificadas e diaclasadas ...................... 
1. Afloramento do Arenito Caiuä. Estrada BR-376, trecho Maringä-Nova Londrina, proxlmidades de Paranavai .......

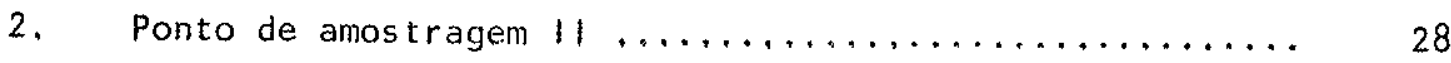

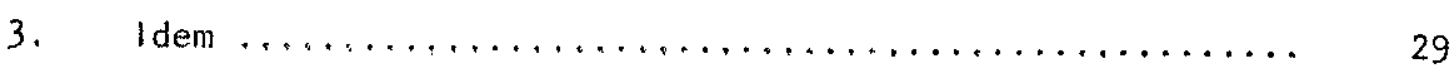

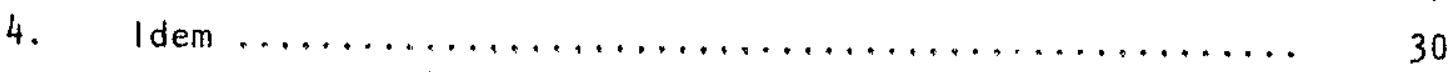

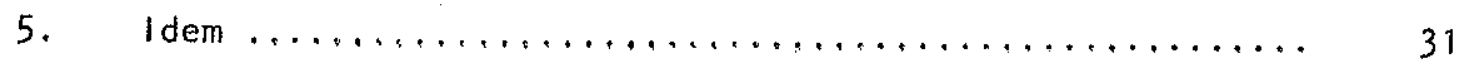

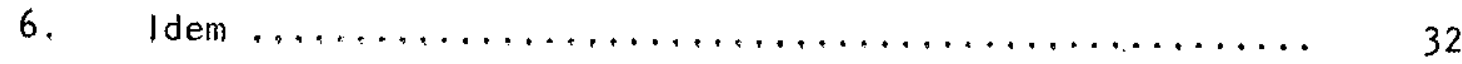

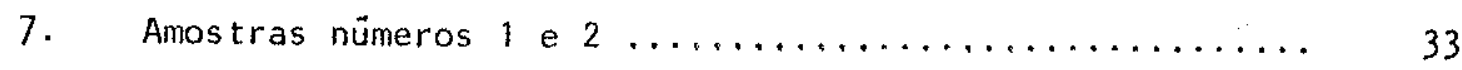

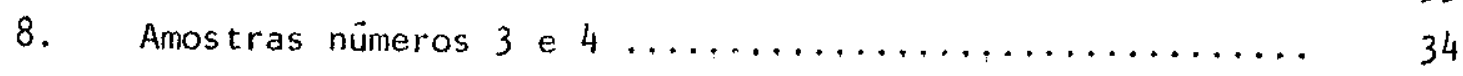

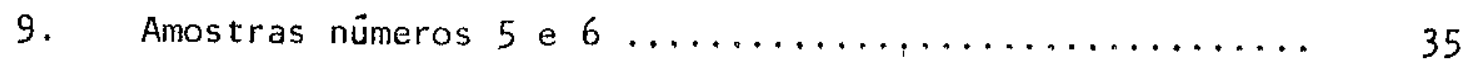

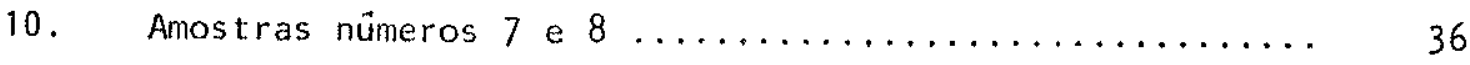

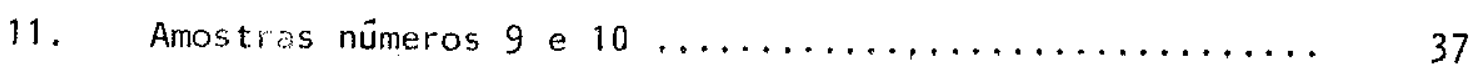

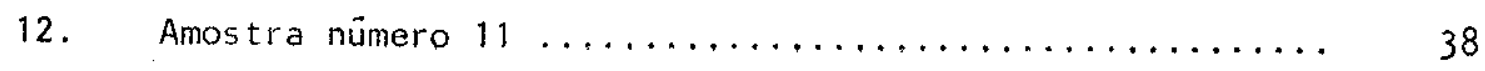

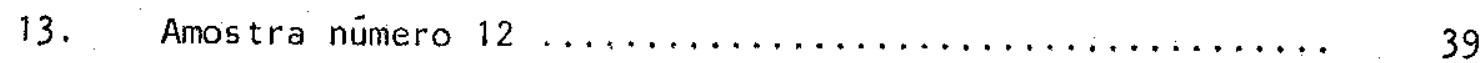

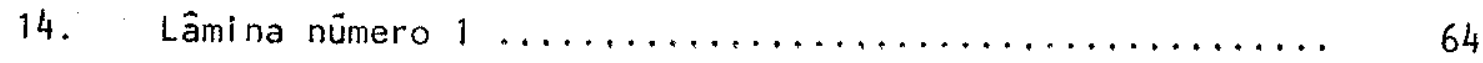

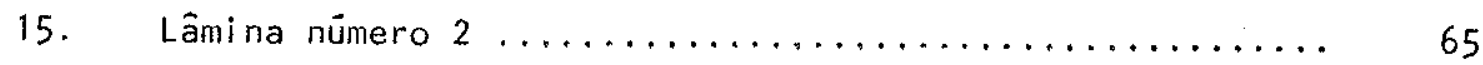

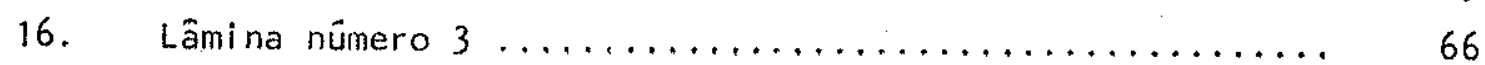

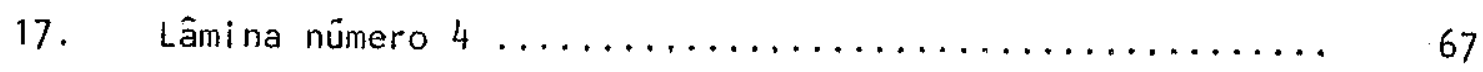

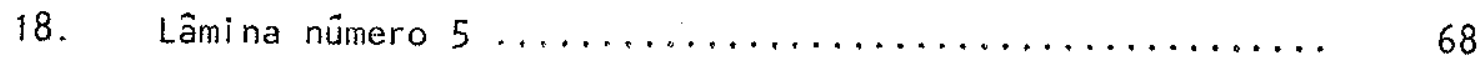

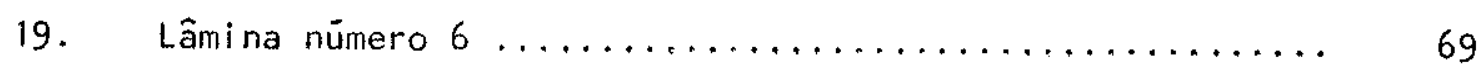

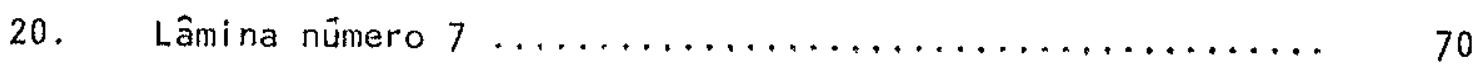

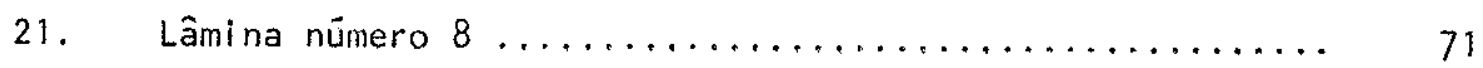

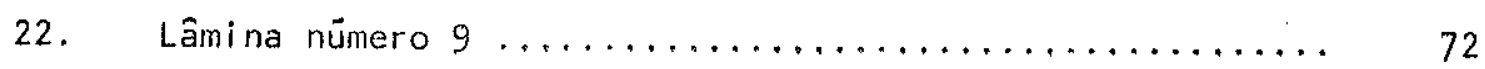

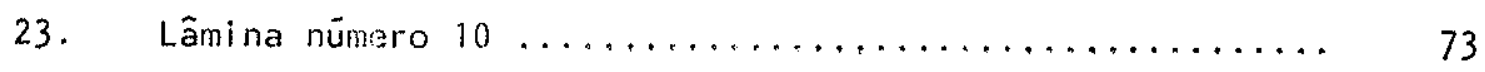

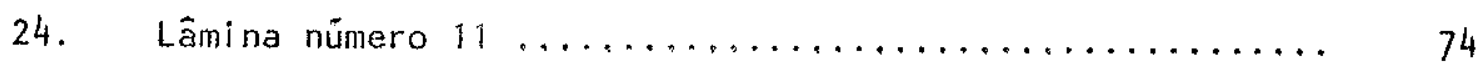

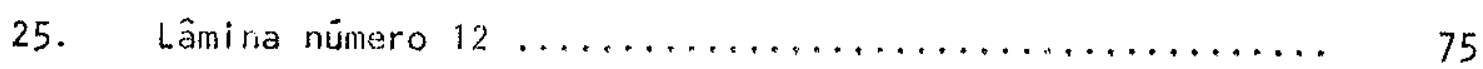

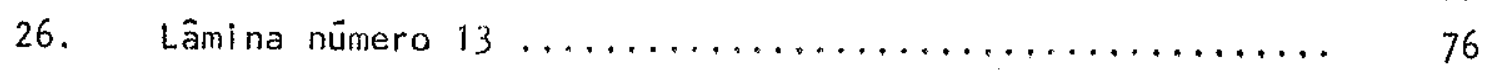

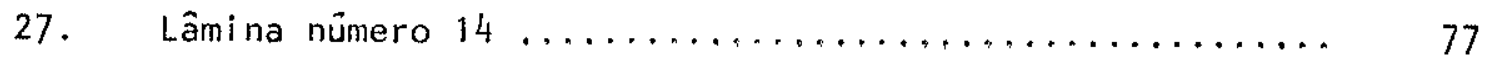


CAPITULO I

O TEMA PROPOSTO

\section{Introdução}

As rochas sedimentares brandas năo têm sido devidamente levadas em consideração quanto às suas propriedades geotécnicas.

Nada parece mais impröprio que este estado de coisas, já que nos dias atuais cristaliza-se uma mentalidade que determina um comportamento baseado não mais no desperdicio inconsequnte, mas na utilização criteriosa e racional dos recursos naturais. Sem düvida essa postura ê abrangente, e assim sendo, atinge obrigatoriamente a Geotecnia, em todos os seus ramos de atividade.

Ocorre, no entanto, que a caracterização das propriedades geotêcnicas é muitas vezes dificultada por uma certa inadequação dos ensaios e normas para a regulamentação de utilização desses materiais, que conduzem quase que sistematicamente à fixação de valores que cerceiam, de imediato a sua aplicação.

A construção de obras de grande porte, principalmente hodrelétri "cas, exige a utilização de enormes volụmes de materiais de construção, solicita com cargas de vulto as fundações, impõe alterações no meio físico, responsäveis por modificações acentuadas nas propriedades dos materiais utilizados. Por outro lado, a relação custos/benefícios tende a tornar-se cada vez maior em função dos grandes investimentos exigidos para aqueles projetos. Esta realidade conduz a considerar-se cada vez mais a aplicação de materiais classificados como menos nobres na construção das referidas obras, e cujos aspectos normativos de emprego esta a exigir urgentes provi dências da moderna tecnologia. Mesmo para obras pequenas, cuja implantação dia a dia mais se justifica, seja do ponto de vista tëcnico ou econômico, os citados materiais devem ser necessariamente considerados, como alternativa lögica de aplicação. 
Os Arenitos Caiuã, rochas sedimentares de ocorrência bastante significativa, particularmente na região sudoeste do estado de São Paulo mas tambëm no norte e nordeste do Paranä e sul do Mato Grosso do Sul, re presentam justamente os materiais que justificam o interesse aqui exposto. Numa região onde o basalto ê escasso, pelo menos em superfície, ë muito natural que os arenitos sejam convenientemente aproveitados.

Com os meios sofisticados que a tecnologia oferece para que se entenda a realidade física dos materiais naturais aqui focalizados, e atra vēs de manipulação criteriosa dos värios tipos desses materiais em condi ções de aplicabilidade específicas, è possível que se cheque às adequações bastante satisfatörias quanto ao uso dos arenitos em questão.

\section{Objetivos do Estudo}

De acordo com o problema posto no item anterior, esboçam-se de imediato os objetivos deste trabalho.

Inicialmente, tratou-se da obtenção e anälise dos parâmetros fí sicos dos Arenitos Caiuä, como o convēm a toda abordagem geotëcnica que se pretenda fazer, de qualquer material natural.

Outro aspecto de importância ê que Arenitos Caiuä apresentam cer tas caracteristicas geotécnicas que justificam tratä-los como "materiais de baixa resistência", como se verả no desenvolver deste trabalho.

Procurou-se seguir um raciocínio que conduza logicamente ao en quadramento dos arenitos referidos no lugar que thes é devido, quanto às suas propriedades geotécnicas.

A compartimentação do maciço arenitico em função de suas proprie dades, particularmente geo mecânicas, foi considerada com muito interesse para possibilitar a aplicação seletiva dos materiais.

Considerou-se ainda oportuna a abordagem da questão relativa às especificações e ensaios que normalizam a aplicação geotēcnica dos mate riais de construção em nosso meio técnico. Com esse espirito, ressaltou-se a contradição entre tais especificaçōes e ensaios com as nossas realidades físicas, particularmente climäticas, as quais conferem às rochas certos atributos, digamos assim, bastante satisfatörios, o suficiente para justificar a sua utilização.

Para atingir os objetivos propostos, foram desenvolvidos e consi derados os seguintes ítens: 
1) Aspectos mineralögicos e petrogräficos, cujas sujeições relativamente à gênese, cimentação, ambiente de deposição e transporte são inegáveis;

2) Elaboração de uma compartimentação tipológica desses materiais, essencialmente qualitativa, em função de descrições macroscōpicas. Destaque a aspectos particulares quanto às anisotropias texturais e es truturais, que conferem, como já se viu antes, diversificaçós significativas no comportamento dos materiais em questão;

3) As propriedades físicas, onde se tratarä da granulometria, massas específicas, porosidades, porcentagem de saturação dos vazios e as suas va riações nos diferentes tipos estudados;

4) Distinção entre o desempenho dos arenitos em função das variações cícli cas de umidecimento e secagem, o que determina, em sintese, a sua durabilidade;

5) Aspectos relativos ãs propriedades geomecánicas dos arenitos, ou seja, sua resistência e deformabilidade, em correspondência ãs variações das propriedades físicas e dos diferentes tipos existentes;

6) Reflexões sobre a sua aplicabilidade, proporcionadas pelo desempenho va riävel de seus tipos de acordo com diversas solicitações e diferentes a plicações, procurando sempre dar relevo aos aspectos, jä mencionados que dizem respeito às especificações, ensaios e critërios realistas de apli cação.

Sem pretender, evidentemente, esgotar essas propostas, espera-se que o interesse pelo tema do trabalho seja despertado, levando a um aprofundamento cada vez maior dos conhecimentos geotëcnicos dos arenitos cailuá e de rochas similares.

\section{Estado da arte}

Pode-se afirmar que muito pouco se faz, até o momento, quanto à se compreender o comportamento geotëcnico dos Arenitos Caiuä. Isto se ex plica, em parte, pelo fato de que essas rochas sedimentares estão sendo estudadas, do ponto de vista geolögico, com mais empenho apenas recentemen te. E inegävel que o esclarecimento de particularidades geolögicas, princi palmente genëticas, representam fatores de importância na elucidação dos parâmetros geotëcnicos dos arenitos em questão.

Mesmo a nivel mundial, não têm sido muitas as manifestações cien 
tifficas do tipo pesquisa ou trabathos têcnicos visando a individualização geotëcnica de rochas brandas, particularmente arenitos. Serão citados a se guir, alguns trabalhos que, pelo seu teor, apresentem alguma . iden tificação que auxiliem, de alguma maneira, na compreensão dos parâmetros geotëcnicos dos arenitos.

Num trabalho que provavelmente seja ünico, até o movimento, pois se trata de um estudo aplicado dos Arenitos Caiua, Robert (1956) estuda os mesmos utilizados, como base estabilizada para fins rodoviarios. Conclui que, na impossibilidade de se executar a base e sub-base das estradas com agregados de rocha, dadas as distâncias exageradas de transporte, na região NE do Paranả, a melhor solução seria o aproveitamento de areia argi lo -siltosa, proveniente da desagregação dos bancos de arenito. Acrescenta que o problema se resume na construção de uma base capaz de suportar os es forços transmitidos pelos veículos atravës da camada de desgaste, para pos teriormente transmití-los respectivamente à sub-base e base.

Invocando a experiência americana da época, Robert recomenda três tipos de estabilizantes:
1) Cimento Portland
2) Asfalto diluído
3) Alcatrão

E para uma densidade de träfego inferior a 1000 veículos/dia, pro põe um pavimento nas seguintes condições:

a) Sub-greide: Solo natural, devidamente compactado.

b) Sub-base: Solo natural local, compactados de acordo com as especifica ções para cada caso.

c) Base: Mistura estabilizada, de solos locais com um dos estabillzantes mencionados acima.

d) Camada de desgaste: Macadame betuminoso tipo "penetração invertida",com espessura compactada de $5 \mathrm{~cm}$.

Tourenc (1974) aborda genericamente o tema "Materiais de Constru ção" analisando questões relativas à classificação e identificação petro gräfica, alteração dos minerais e estruturas dos referidos materiais, aten do-se ainda à anälise das propriedades mecânicas que influem na classifica ção. Yoshida (1974) trata de aspectos relativos à Petrografia, Mecânica dos Solos e Mecánica das Rochas na tecnologia de materiais naturais de construção, frisando as dificuldades inerentes à falta de uma sistematização adequada nos estudos das propriedades tecnolögicas para värios usos. 
Barton (1974) descreve a mudança no desempenho geotēcnico de arenitos frịa vels da Inglaterra a alterações de umidade durante a amostragem. Nessa més ma linha, citam-se Raymond, Gaskin, Davies e Van Dalen (1975), que aplicam e analisam os testes de vibrações, carregamento e triaxiais em materiais para lastros de estradas de ferro do Canadä; e Spence, Ramsey e Dhir (1974), que avaliam ensaios de resistência efetuados em agregados de vä rios tipos de rochas.

Importante contribuição ë dada por Bell (1978), que estudou os a renitos Fell, de Northumberland, Inglaterra. Eles foram examinados petro gräficamente, o que incluiu anälises modal e textural bem como suas pro priedades físicas e mecânicas, ou seja, densidade, porosidade, resistência, dureza e propriedades elästicas a värias profundidades. Essas vārias medi das foram correlacionadas para avaliar as influências de uma propriedade em relação à outra. Aquelas que influenciaram mais significativamente, fo ram consideradas como as propriedades indices mais üteis e utilizäveis co mo base de uma classificação geotëcnica de tais arenitos. Esses estudos permitiram concluir que a resistência à compressão simples ( $\sigma c$ ) tem significativas correlaçôes com a resistência à tração, medidas de dureza e com - Mödulo de Young. Segundo o autor, das medidas de dureza, aquelas levadas a efeito com os escleroscópio Shore e o martelo de Schmidt são bastante simples e rápidas, sendo os seus resultados relacionados significantemente com värias medidas de resistência, com o Mödulo de Young, densidade e poro sidade.

E possivel associar-se o estudo dos Arenitos tipo Caiuä com aque les especificos para "materiais de baixa resistência", estabelecendo impor tantes correlações a partir desse procedimento.

0 assunto "Caracterização geotẻcnica de materiais de baixa resis tência", apresenta evidente interesse para a Geotecnia, dado que trata de materiais que estão situados numa faixa entre os solos característicos e os maciços rochosos francamente considerados como tal.

No entanto os interessados encontrarão de inicio, obstäculos sig nificativos para sua abordagem, decorrentes da pröpria conceituação do que sejam materiais de baixa resistência.

Rocha (1977), consciente dessas dificuldades, jã disse que uma questão básica que se levanta é a do conceito de rocha de baixa resistêncla, que implica em dois problemas:

a) 0 estabelecimento de critërios de distinção entre solos e rochas de tranșição para solos; 
b) A fixação do limite superior para a resistência.

Em recente trabalho, Mello (1979) chama a atenção para o im portante fato de que os chamados horizontes decorrentes do perfil de decom posição de rochas apenas existem na aparência, mas que os graus de precí são nas tentativas de que sejam utilizados para indicar comportamentos di tintos dos materiais aos quais se referem, são extremamente pequenos. Ele ainda se refere ao fato de que existe um contínuo absoluto de : transição gradual dos parâmetros geotẽcnicos mëdios, de acordo com a profundidade, e cita Deere e Patton (1971) segundo os quais: "As descontinuidades de ca da zona constituem o ünico meio confiävel para distinguir uma zona da ou
tra".

Adentrando mais o assunto, Mello analisa as implicações conti das no termo "solo residual" e diz que, de um lado observa-se a extrema he terogeneidade que impera numa massa de solo, como no exemplo dos matacões residuais envolvidos por argilas siltosas moles; e de outro lado, a exis tência das descontinuidades de estruturas preservadas da rocha original, e que podem, tanto uns como outros, condicionar e dominar, numa primeira aproximação, o comportamento dos parâmetros geotëcnicos do solo.

Kanji (1975) focaliza de maneira bastante convincente a questão das propriedades mecânicas dos chamados materiais de transição, e que po dem consistir de (1) rocha intemperizada mais ou menos uniformemente, e cu ja resistência seja maior que a do solo, ou (2) de blocos de rocha dura ou pouco intemperizada, circundados ou alternados por solos, que e o caso mais comum. Citando Deere e Patton (1971), Vargas (1971), Barata (1969) e Showers (1963), Kanji se detẻm à anälise dos tipos caracteristicos que com põem a faixa dos materiais de transição, entendendo como sendo os saproli tos e os maciços rochosos, os seus limites. Os saprolitos, têm sido estuda dos pela Mecânica dos Solos convencional, merecendo porēm as feições geoló gicas que apresenta, como as descontinuidades e anisotropia, uma abordagem
paralela.

Showers (1963) descreve com pormenores saprölitos de rochas gra níticas ou equivalentes, analisando aspectos de sua compressibilidade, per meabilidade e resistência, em funçäo da composição mineralögica e propriedades físicas, como índice de vazios.

Vargas (1974) procura identificar os materiais situados na zona entre materiais transformados em solos e a rocha sà ou fissurada, do substrato rochoso. Estabelece que esses materiais são, basicamente: solos poro sos, solos residuais e lateritos. 
Tem-se desenvolvido importantes estudos relativos à caracteriza ção geotëcnica dos materiais de baixa resistência, particularmente no que se refere aos granitos alterados. Dearman (1976) elaborou um trabalho no qual propõe uma avaliação em separado dos estudos da desintegração física, química e solução daquelas rochas. Ele considera ser a solução um importan te componente do intemperismo de rochas silicatadas, comprovando os significativos aumentos usuais na porosidade com o progredir do intemperismo. In do além, Baynes e Dearman (1978), revelam os estudos do "microtexturas" de granitos alterados, relacionados âs porosidades geotëcnicas dos mesmos. Se gundo eles, as mudanças nas referidas propriedades induzidas pelo intemperismo são atribuídas ao microfraturamento, pela abertura dos limites exte riores dos grãos e desenvolvimento de porosidade intergranular. Desenvol vem um modelo, envolvendo a "microtextura" de produtos argilosos de intemperismo e a intensidade deste, para explicar os valores tipicamente elevados dos ângulos de resistência interna desse material, e se preocupam tam bëm com a anälise de sua deformabilidade.

Kowalski (1975) examina as diferenciações nas propriedades de re sistência de rochas dentro da zona de influência do intemperismo. Conclui que mudanças cíclicas reduzen a resistência, levam à expansão e redução de volume. Registra que tais processos originam e/ou acentuam uma anisotropia primäria das rochas e no seu fraturamento, quando a rocha é maciça, conduzem a um acamamento ou laminação aparente e quando ela jä ë estratificada, leva a uma separação da estratificação.

Tentativas têm sido feitas para correlacionar índices de alteração obtidos a partir de amostras de uma rocha em diversos estägios de alte ração, e os mesmos indices obtidos em laboratôrio. Aires-Barros (1978) de senvolveu esse tipo de estudo com uma grauvaca. Amostras dessa rocha em três diferentes estägios de alteração, foram coletadas de uma sondagem ver tical e os processos de intemperismo foram avaliados por observações geoquímicas e petrolögicas. 0 primeiro processo possibilitou avaliar a perda ou ganho de elementos químicos. Seguiu-se a quantificação do Intemperismo atraves da utilização dos "indices de alterabilidade" e finalmente a aplicaçäo desses indices às rochas referidas. Finalmente, segundo ainda este autor, as rochas foram submetidas a testes de "envelhecimento" do tipo tēr mico.

Valores de velocidade de propagação do som, porosidade, permeabi lidade e expansão foram tambëm determinados. Finalmente, elaboroumse a necessäria correlação entre os ensaios referidos: Aires-Barros conclui que sob as condições de envelhecimento termal, as grauvacas por ele estudadas 
devem, no laboratôrio, serem submetidas a 5 anos de condições de teste, quando secas, e a 1 ano, quando saturadas, para atingir as mesmas condições das amostras naturais.

Onodera, Yoshinaka e Oda (1974) realizaram ensaios triaxiais com granitos sãos e alterados, determinando parâmetros comparativos para os värios tipos ensaiados. Tais ensaios foram efetuados com corpos de prova com alturas e diâmetros de, respectivamente 10 e $5 \mathrm{~cm}$, que foram submeti dos a contra-pressões de 10 a $20 \mathrm{~kg} / \mathrm{cm}^{2}$ para prover uma saturação completa e em seguida a pressões confinantes de $100 \mathrm{~kg} / \mathrm{cm}^{2}$ e a carregamentos com aumentos de 5 a $10 \mathrm{~kg} / \mathrm{cm}^{2}$ por minuto. Concluíram que os valores do ângulo de atrito interno $\phi$ variava de $50^{\circ}$ a $60^{\circ}$ para exemplares razoavelmente sãos, e de $30^{\circ}$ a $40^{\circ}$ para aqueles altamente alterados. Observaram também que, uma mudança de atë $7 \%$ na porosidade em rochas altamente intemperizados, o decrëscimo de $\phi^{\prime}$ correspondente é pequeno. No entanto, o mesmo não ocorre com a coesão aparente $c^{\prime}$, pois o aumento da porosidade de 1,1 a $4 \%$ faz com que aquele parâmetro varie de 150 a $50 \mathrm{~kg} / \mathrm{cm}^{2}$. 0s mesmos autores afirmam que mesmo num granito com porosidade maior que 3 a $4 \%$, os valores de $c^{\prime}$ ainda permanecem por volta de $50^{\circ}$, e explicam que isto se deve em parte ao efeito de alguma coesão residual dos constituintes granulares relacionada à uma certa coesão estrutural dos mesmos, devida a certo entrelaçamento dos grãos, e quando a porosidade torna-se maior que 15 a $20 \%$, a desintegra ção terä avançado a um tal estägio que aquela coesão estrutural deixa de existir.

Muito se tem falado e escrito a respeito da influência dos parâm metros de resistência mecânica de materiais basâlticos alterados particularmente os tipos brechöides, e os materiais secundärios existentes em jun tas e fraturas de grande extensão, nos derrames basālticos. Sem dūvida al guma tal influência não é de maneira alguma negligivel e pode ser constata da facilmente a partir dos ensaios geomecânicos executados para värios pró jetos de fundações de barragens. Normalmente, tais feições são particularí zadas como sendo basaltos brechados com inümeras fraturas preenchidas por materiais argilosos branco e creme, tipos vesiculares e vesículo-amigdaloi dais alterados, com fraturas preenchidas pelos mesmos produtos argilosos jä mencionados, ou mesmo calcita, ou niveis de contatos entre derrames. Re gistraram-se, para essas feições, em ensaios realizados em fundações de barragens como llha Solteira, São Simão, Agua Vermelha e outras, valores de ângulo de atrito $\phi$ "in natura", variäveis entre $13^{\circ} \mathrm{e} 35^{\circ}$. Vemos que tais valores correspondem, sem sombra de düvida, aos materiais de baixa resistência considerados por Rocha como tal, ou mesmo a solos típicos. 
Kanji (1969) preocupou-se com a questão da resistência da interfaces solo-rocha, que configura, sem düvida, uma região de propriedades mecânicas críticas. Partiu da hipôtese, anteriormente levantada por outros autores, de que aquela interfaces possuia resistência menor do que o solo que dela fazia parte, considerado isoladamente. Ensaiou então amostras de $6 \times 6 \mathrm{~cm}$ em uma caixa de cisalhamento com velocidades de deformação de $2 \times$ $10^{-5}$ a $5,2 \times 10^{-2} \mathrm{pol} / \mathrm{min}$, com deslocamentos mäximos de 0,32 pol. Essas amostras consistiam de calcärio onde o solo na interfaces solo-rocha era composto pela seguinte mistura:

$\begin{array}{ll}\text { Quartzo } & 25 \% \\ \text { Caolinita } & 30 \% \\ \text { llita } & 10 \% \\ \text { Minerais de camadas compostas } & 20 \% \\ \text { Clorita } & 15 \%\end{array}$

Tal mistura resultou num silte com areia fina, com indice de plasticidade de $12 \%$. A interfaces era de dois tipos: um resultante da su perficie do pröprio corte da rocha em duas partes, originando uma superficie irregular; o outro produzido por polimento em mesa petrogrä́fica giratö ria.

Kanji conclui que, no primeiro, sob a mesma deformação de 0,32 pol., o decrëscimo de resistência ê muito maior para a interfaces do que para o solo unicamente, implicando, tal fato, na redução do tempo de estabilização de maciços rochosos, cujas resistências tenham sido mobilizadas.

Quanto ao segundo caso, observou que a resistência da interfaces tem valor bem mais pröximo que a do solo.

Kanji sugeriu então na ëpoca (1969) que se definissem as magnitu des das irregularidades da interfaces a partir da qual a redução de resistência è mais observada.

Kanji (1975) afirma que, em termos genëricos, as principais cam racterísticas e problemas decorrentes apresentados pela zona de transição são:

a) Grande variabilidade das resistências dos materiais constituintes, desde muito baixa a muito alta;

b) A resistência do maciço è muito heterogênea, podendo apresentar valores multo baixos quando fraturas possuirem um preenchimento considerävel de materials argilosos, por exemplo;

c) Possui estrutura de comportamento incerto e ê de dificil prospecção amos tragem; 
d) Possuem permeabilidade errätica, podendo apresentar perdas totais de ägua de circulação nas sondagens e grandes absorções de calda de cimento, ou ser de dificil tratamento por injeções;

e) 0 material terroso de preenchimento tem frequentemente as mesmas pro priedades dos saprólitos, com estrutura remanescente da rocha original e grande erodibilidade.

O mesmo autor enfatiza ainda das dificuldades relativas à descri ção e caracterização do material, jä que o reconhecimento geológico super ficial e comprometido pela espessa camada de solo de alteração sobrejacen te à zona de transição e ainda pelo fato de que não existe ainda um mētodo de sondagem satisfatörio para a amostragem, jā que as percussões são impedidas por camadas de pedregulho presentes ou mesmo pelo aumento excessivo da compacidade dos materiais, e as rotativas frequentemente não recuperam feições de interesse entre os blocos ou matacões de rocha.

Quanto à compressibilidade desses materiais, dois modelos extre mos podem ser montados para compreender o seu comportamento, e que são:

a) Poucos e pequenos corpos rígidos imersos numa matriz terrosa;

b) Corpos rígidos grandes numa matriz escassa.

Evidentemente há que se considerar o efeito de escala das descon tinuidades e heterogeneidades da matriz e a disposição dos blocos de rocha, e a variação dessa propriedade no maciço,

No primeiro modelo, os blocos de rocha não se tocam durante a de formação, não interferindo no processo, ficando a compressibilidade total a cargo do material terroso. No segundo, pequenas deformações farão os värios blocos entrarem em contato e constituírem um esqueleto interrompendo o processo de deformação.

No que se refere à resistência ao cisalhamento, ela ë ditada pela presença de descontinuidades e grande porte ou por sistemas de fraturamentos muito pronunciados, que se configuram em planos de fraqueza. Kanji, no entanto, alerta para a complexidade da estrutura dessa zona de transição como condicionante para se estimar a sua resistência, e cita um exemplo na vertente oceánica da Serra do Mar, onde encostas naturais que apre sentam ruptura abrangendo aquela zona, com $80 \%$ a $90 \%$ de rocha na sua const tuição, tinham inclinação superior a $22^{\circ}$. Afirma que, embora não se conhe çam as pressões neutras atuantes no momento da ruptura, pode-se concluir que os ângulos de atrito não drenados mobilizados correspondiam a um valor semelhante aos dos solos ou intermediärio entre esses valores e os das ro- 
chas, o que aponta os solos de preenchimento como agentes importantes no processo de ruptura.

\section{Indicações do caminho a seguir}

Pode-se afirmar que o avanço nos estudos dos arenitos Caiuä em consonância com os objetivos desse trabalho deverão obedecer âs seguintes etapas:

1) Individualização mais precisa dos diferentes tipos de arenitos Caiuã, utilizando-se descrições padronizadas que não deixem düvidas quanto aos aspectos macroscöpicos relevantes e levando-se em. consideração a influência dos processos deposicionais na variação tipolögica;

2) Abordagem mais pormenorizada dos parâmetros físicos, particularmente aqueles relativos à caracterização de vazios e cimentação;

3) Compreensão adequada dos fenômenos de intemperismo tropical responsäveis pelas modificações de suas propriedades físicas e geomecânicas;

4) Caracterização dos tipos litolögicos em função dessas propriedades;

5) Elaboração de normas visando a viabilização da aplicabilidade descses se dimentos, normas essas que sejam pertinentes à realidade geogrä́ica é climātica brasileira;

6) Observações sistemáticas do desempenho das rochas em questão, quando jä aplicadas a certas obras civis. Como variante a esta proposta, seria útil a execução de obras experimentais, como por exemplo, aterros, que permitiriam, tambèm, aferir-se o comportamento real com o de laboratörio, possibilitando o estabelecimento de indices correlativos, como aqueles definidos por Airesmarros (1978).

Sem düvida ê uma proposta abrangente, que se incorpora às preocu paçōes universais quanto à compreensão das propriedades geotēcnicas de rochas brandas, temas com os quais este trabalho se preocupa e desenvolve as primeiras idëias a respeito. 
CAPITULO 11

OS DADOS

\section{A Formação Caiuá no Pontal do Paranapanema}

\section{Introdução}

A Formação Caiuã, composta pelos arenitos do mesmo nome, tem pro porcionado amplas discussões nos meios geolögicos, particularmente no que se refere aos aspectos estratigräficos. Confinada a uma região no Centro- Norte da bacia do Paraná, já foi considerada como sendo de origem deltaica e idade provavelmente terciäria, restrita à calha do rio Paraná (Baker, 1923), e eölica e em posição estratigräfica acima dos derrames basālticos e abaixo da Formação Bauru (Washburne, 1930). Os posteriores responsäveis pelos estudos daquela Formação, seguiram as idéias do primeiro, modificando-a um pouco, ou seja, consideraram-na flüvio deltāica (Bigarella, 1949; Mezzalira e Arruda, 1965; Suarez, 1973; Mezzalira, 1974), ou então esposaram a concepção de Washburne entre eles Maack (1941); Scorza (1952) e Frei tas (1955), o qual posteriormente aderiu (1973) áqueles que propõem ser tais arenitos fluvio-deltäicos.

Böslo e Landim (1971) e Landim e Fülfaro (1971), deram continuidade aos estudos sobre a Formação Caiuä; os primeiros apoiados em sedimentologia, compararam os arenitos Caiuá com outros de idade Neocenozöica da Região do Pontal do Paranapanema, de Rio Claro e Casa Branca - Mococa e concordaram com as idëias de Baker; os segundos, apresentaram um proposta para a gënese da Formação Caiuá, pela comparação com outros arenitos que julgaram idênticos, existentes a noroeste do Parană.

Landimi e Soares (1976), adentraram mais a questão e concluiram terem sido os arenitos em questão acumulados em um embaciamento situado na continuação para oeste do arco de Ponta Grossa, apös o tërmino do vulcanis mo Serra Geral, sendo portanto de idade prë-Formação Bauru. 
Consideraçōes sobre as ocorrências

Julga-se que a ärea de deposição do Caiuã tenha se caracterizado por uma räpida subsidência devida a falhamento normal, num quadro tectônico de vales de afundamento, onde o barramento de drenagem foi feito atravës de soleiras; isto teria propriciado a formação de imensos lagos naturais, onde äguas estacionärias permitiram a sedimentação arenosa de fundo, na forma de frentes gradacionais flüvio-deltaicas ou lacustre-deltaicas (Fülfaro e Suguio, 1974).

Landim e Soares (1976), afirmam que após o vulcanismo Serra Geral, sucedeu-se um curto ciclo erosivo (o Pôs-Gondwânico, Soares e Landim, 1976) que modelou uma superficie suavemente ondulada sobre a qual deposita ram-se as Formações Caiuá e Bauru, no ambiente tectônico descrito acima, na bacia do Paraná. Tais depósitos cretäcicos continentais ficaram preservados apenas nas partes centro e norte da Bacia. Afirmam ainda que a pas sagem da Formação Caiuä para a Bauru faz-se atravēs de uma fäcies de canal e transbordamento, representada por um pacote de arenitos fluviais, com seleção regular, boa maturidade textural e mineralögica que gradam para arenitos imaturos. Essa fäcies foi denominada pelos referidos autores de Fäcies Santo Anastäcio.

Segundo ainda Landim e Soares (1976) a direção do transporte era, ao tempo do Caiuä, $580^{\circ} \mathrm{W}$, passando para $\mathrm{N} 50^{\circ} \mathrm{W}$, durante a deposição do mem bro inferior da Formação Bauru. Citando ainda diversos autores, eles concluem ter havido uma mudança no sentido das paleocorrentes, que no tempo do Caiuã eram dirigidas para oeste, e à época da deposição Bauru teriam mu dado para S-SW ou mesmo SW-S.

Freitas (1973) verificou que as camadas cruzadas mergulham $15^{\circ}$ a $30^{\circ}$ para oeste.

Em recente trabalho, Soares, Landim, fülfaro e Sobreiro Neto (1979) caracterizaram a gênese do Sistema flüvio-lacustre Bauru, no qual incluem como unidades basais as Formações Caiuä e Santo Anastäcio. Em intervalos pós-basältico e prë-Bauru, falhamentos e levantamentos de arcos marginais como os da Serra do Mar (Fülfaro, 1975), Canastra ao norte e Pon ta Grossa ao sul, esculpiram um embasamento muito irregular onde se apoiou - início do sistema flúvio-lacustre. Soleiras em grande nümero governavam a deposição dos sedimentos da base, mais finos ou menos selecionados a mon tante das mesmas, e mais arenosos e melhores selecionados e de ambiente energëtico mais alto, para jusante. 
Do ponto de vista estratigräfico, aqueles autores definem o cha mado Sistema Cretäceo do Estado de São Paulo, propondo a denominação de cinco Unidades, das quais transcreveremos duas, a seguir:

Unidade 1: arenitos finos a mëdios, seleção regular a boa, arroxeados com estratificação cruzada de grande porte, assentados discordantemente sobre basaltos, correspondentes ã Formação Caiuã;

Unidade 2: arenitos de granulação muito fina a mëdia, vermelhos a arroxeados, com estratificação cruzada de baixo ângulo a plano-paralela, intercalando raras camadas de lamito maciço; ocorrência dominante no sudoeste do Estado, assentando gradacionalmente sobre a Unidade 1 e discor dantemente sobre o basalto, correspondente à Formação Santo Anastäcio.

Esta è a mesma Fäcies Santo Anastäcio, como denominada originalmente por Landim e Soares (1976), e agora designada de Formação jā que são identificadas todas as características que permitem considerä-la uma unida de mapeävel, segundo Soares, Landim, Fülfaro e Sobreiro Neto (1979).

Limitamo-nos à descrição somente das unidades 1 e 2, pelo fato de que o Pontal do Paranapanema e o domínio geogräfico das mesmas.

Segundo a interpretação daqueles autores, a Formação Caluã é composta de arenitos arroxeados de granulação fina a mëdia, com frações muito fina e grosseira, ocorrendo subsidiariamente, com matriz varlävel de 5 a $15 \%$; os grãos são cobertos por uma película de öxido de ferro ou limonita provenientes de processos secundärios. 0s corpos de arela ocorrem em grandes bancos e cunhas, e apresentam estratificaçäo cruzada de grande por te.

Esses arenitos passam gradativamente para a Formação Santo Anastäcio sobreposta aos mesmos com o aumento do teor da matriz. As äreas de ocorrências típicas dos arenitos Caiuã são o extremo sudoeste do Pontal do Paranapanema, a oeste de Itororö do Paranapanema, com boas exposições entre Teodoro Sampaio e Porto Euclides da Cunha, na altura da cidade de Diamante do Norte, às margens do Paranapanema, e no Rio Paranä, a jusante de Panorama, particularmente na margem esquerda. Em geral no dominio desta Unidade ocorrem extensas colinas com encostas recobertas por colüvios espes sos.

Os arenitos Caiuã são, em geral, de fäcil desagregabillidade.Suas cores são vermelho escuro na parte inferior e rosa na superior (Washburne, Maack, Scorza) ou roxo violäcea na área do Pontal (Mezzalira). Segundo Soa res e Landim, são vermelho escuro e violeta, De acordo com nossas observações, eles são marrom avermelhados quando se trata dos arenitos sem estra- 
tificação ou com estratificação incipiente, e violãceos aqueles com estratificação.

Esses sedimentos não possuem seixos dispersos, concentrados nos pacotes ou basais; são afossilifferos e algumas vezes carbonāticos, embora essas ültimas ocorrências se restrinjam, aparentemente, ao terço inferior do pacote, pröximo portanto ao contato inferior, com o basalto, devendo ser - carbonato de natureza epigenêtica. Constituem-se quase que exclusivamente de areia, sendo insignificante as percentagens de finos (silte e argila), na sua composição granulomêtrica.

Suarez (1973) afirma que a composição mineralógica dos arenitos è quartzo dedrítico, pouco feldspato e rara mica, constituindo-se na fração leve, e zircão, turmalina, estaurolita, magnetita e granada como repre sentantes da fração pesada. Basicamente, tal composição reflete a do Areni to Botucatu, do qual è quase certo tenham provindo os Arenitos Caiua, por erosão e retrabalhamento.

A espessura da Formação Caiuä è, segundo Soares e Landim (1976), variävel desde $60-70 \mathrm{~m}$ em Presidente Epitäcio atë mais de $250 \mathrm{~m}$, na região de Paranavaí. Aliäs, acreditamos que essa ültima ocorrência esteja associa da à presença de uma estrutura pertencente ao conjunto daquelas inferidas por Suarez, de direção NE, tal ê a evidência observada no campo nas proximidades de Paranavaí, estrutura aquela associada ao controle do Rio Parana panema; observando-se os mapas topogräficos-geolögicos disponíveis, nota-se um cotovelo no curso do referido rio, na continuação do traço da estrü tura em questão, a NE da referida cidade. A Formação Santo Anastāicio terá espessura mäxima de $80 \mathrm{~m}$.

Nos afloramentos aos quais tivemos acesso, notamos a configura ção de altos barrancos nos Arenitos Caiuä, como jä o haviam notado tambëm Soares e Landim. Esta aparente contradição entre serem esses sedimentos facilmente desagregáveis e ao mesmo tempo suportarem altos barrancos, è ex plicada por processos de intemperismo ligados ã limonitização.

Nas partes mais elevadas da topografia ocorre uma areia fina a mëdia, marrom ou castanho avermelhada, às vezes um pouco argilosa, em algu mas amostragens com tonalidades amarelas ou arroxeadas. Pensamos ser tal material produto de desagregação dos Arenitos Caiuä, constituindo o que po deríamos chamar de "solo residual ou solo de alteração do Caiuä". No entan to, Soares e Landim jä documentaram que na região do Pontal ocorrem também depösitos constituidos por areias avermelhadas, correlatos á superfícle Sul Americana, de idade Terciäria, cobrindo tanto os arenitos da Formação 
Caiuä como os da Formação Bauru, e que podem ser facilmente confundidos com os solos dos Arenitos Caiuá, devido ãs suas características sedimentolögicas e cores avermelhadas, em grande parte coincidentes com os arenitos em apreço.

Os arenitos da Formação Santo Anastäcio (Landim e Soares, 1976), têm como ärea de referência o vale do Rio Santo Anastäcio, onde ocorrem as melhores exposições. São sedimentos arenosos de granulação média a fina, sendo esta dominante e com as frações muito finas e grosseiras subsidiärias; o teor de matriz ê menor que $10 \%$, a seleção ë moderada a boa, sen do os grãos mëdios arredondados e os finos subarredondados e angulares, re cobertos por uma película ferruginosa.

São constituídos de quartzo ( $80 \%)$, abundantes grãos brancos de opala ou calcedônea $(\sim$ 15\%), feldspatos $(\sim 5 \%)$ e minerais pesados. Ocorrem em corpos tabulares de 1 a $5 \mathrm{~m}$ de espessura, apresentam incipiente estrat ficação cruzada de baixo ângulo; podem ocorrer lamitos, parcialmente areno sos e vermelhos, de espessura inferior a $0,5 \mathrm{~m}$, separando os corpos de are nito. Esta fäcies descrita passa lateralmente para leste e para cima a outra denominada por Soares e Landim, de Ubirajara: são arenitos ricos em grãos brancos de calcedônea ( $(10 \%)$, com raros grãos de basalto ou argila; apresentam conglomerado basal com grãos e seixos de basal to e calcedônea. São fundamentalmente arenitos de granulação fina dominante, variando de muito fina a grosseira, com teor de matriz siltica e lamítica bastante variāvel, ao redor de $10 \%$. Os grãos mëdios a grosseiros apresentam arredonda mento variâvel, desde bem arredondados atë angulosos, e ocorrem em bancos de atë $1 \mathrm{~m}$, com estratificação plano-paralela incipiente e cruzada de balxo ângulo, com cores amarelo e creme na base e vermelhos para cima (Landim e Soares, 1976).

0 contato inferior da Formação Caiuä é de discordância com os ba saltos da Formação Serra Geral, e o superior ë transącional com os arenitos da Formação Santo Anastäcio. Esta por sua vez, passa lateralmente e acima, por transição e interdigitamento, á fãcies Ubirajara, que pode se assentar sobre os basaltos, e neste caso discordantemente apresentando con glomerado basal com abundantes seixos de calcedônea e basalto. Lateralmente, pode tambëm estar em contato com a parte mëdia da Formação Bauru, e acima com os arenitos conglomeräticos da parte superior da mesma (Landim e Soares, 1976). 


\section{Parâmetros Estatísticos a partir das curvas cumulativas}

Foram estudadas por Suarez (1973) e são o diâmetro mëdio aritmētico $\left(M_{z} \phi\right)$, o desvio padrão gräfico inclusivo $\left(\sigma_{1}\right)$, a assimetria gräfica inclusiva $\left(S K_{1}\right)$ e a curtoșe gräfica $\left(K_{G}\right)$.

As förmulas para os câlculos desses parâmetros foram, respectiva mente (Folk e Ward, 1957)

$$
\begin{aligned}
M_{z} & =\frac{\left(\phi_{16}+\phi_{50}+\phi_{84}\right)}{3} \\
\sigma_{1} & =\frac{\left(\phi_{84}-\phi_{16}\right)}{4}+\frac{\left(\phi_{95}-\phi_{5}\right)}{6,6} \\
S K_{1} & =\frac{\phi_{16}+\phi_{84}-2 \phi_{50}}{1\left(\phi_{84}-\phi_{16}\right)}+\frac{\phi_{5}+\phi_{95}-2 \phi_{50}}{2\left(\phi_{95}-\phi_{5}\right)} \\
K_{G} & =\frac{\phi_{95}-\phi_{5}}{2,44\left(\phi_{75}-\phi_{25}\right)}
\end{aligned}
$$

O desvio padrão gräfico inclusivo apresenta valores mínimos e mä ximos de 0,307 e 1,572, o que significa que algumas amostras exibem boa se leção, enquanto que outras são pobremente selecionadas, porēm essas duas situações são consideradas extremas, podendo-se dizer que normalmente os sedimentos aqui tratados são moderadamente selecionados (Folk, 1966).

Quanto aos diâmetros médios aritméticos, seus valores abrangeram um minimo de $0,865(0,53 \mathrm{~mm})$ e $2,58(0,155 \mathrm{~mm})$, ou seja, areias grossa e fina, respectivamente.

0 grau de assimetria varia entre $+0,600$ e $+0,002$, ou seja, muito positiva (Folk, 1966), indicando enviesamento voltado para os finos. Valo res positivos da assimetria caracterizam äreas de baixo nivel de energia, ou seja, quando o agente transportador não chega a eliminar a fração fina do sedimento.

No que se refere ã curtose, ou seja, a medida que retrata o grau de agudez dos picos de distribuição da frequência, seus valores variam des de 0,694 atẻ 4,68 , mas este ültimo valor parece algo anômala, jả que os vá lores mảximos desse parâmetro estão por volta de 2,7. Assim sendo, as distribuições abrangem os tipos plati, meso, lepto e muito leptocúrtica, ou 
seja, os arenitos Caiuä podem conter caudas de sedimentos mais finos

e mais grosseiros ou mesmo serem sedimentos bem selecionados na parte central da distribuição.

\section{Arredondamento}

Para esse estudo, foram escolhidas as classes granulomëtricas de 0,125 e $0,250 \mathrm{~mm}$, e utilizada a tabela de comparação visual de arredonda mento e esfericidade da areia segundo Krumbein e Sloss (1963). Para o cālculo da mëdía e desvio padrão foi usado o mëtodo analítico. os valores do arredondamento para as duas classes acima, variaram respectivamente de 0,47 a 0,67 e 0,57 a 0,64 o que autoriza a considerar o arredondamento nas classes "Arredondado" e "Bem arredondado".

\section{Textura Superficial}

Suarez (1973) efetuou o exame da textura superficial dos grãos de quartzo nas frações de 350 e $500 \mu$, de preferência, com as partículas dentro da ägua, que favorece a eliminação, em parte, dos reflexos de luz indesejäveis. Assim caracterizou dois tipos de grãos, uns com a superfície lisa, quase polida, com algumas imperfelções, com boa transparência em ge ral, outros com superfície äspera e translücida, mas todos eles com fratü ras internas, incipientes.

\section{Estruturas Sedimentares}

As considerações que se seguem, foram feitas por Suarez (1973).

Destacam-se as estruturas singenëticas do tipo : estratificação cruzada, com espessura total da ordem de 3 metros, mas ocorrências de até 50 metros foram detectadas. Os valores do ângulo das mesmas variam entre $5^{\circ}$ e $28^{\circ}$, e são, de modo geral, notadas em arenitos de textura fina a mëdia. Quando os ângulos são de valores baixos, as camadas terminam tangenciando um plano, que è o truncamento da unidade sedimentar inferior, não tendo sido constatada a presença de clastos mais grosseiros entre as lâmi nas. 
textura fina, fazendo sobre a superfície erodida de arenitos com laminação inclinada.

Laminação horizontal tambëm ocorre, formada por lâminas milimétricas de arenito fino, de coloração violäcea, tambẻm sobre unidades com laminação inclinada.

Os tipos de estruturas descritas, evidenciam que as condições de äguas correntes efetivas alternavam com períodos de äguas calmas, aos quais se sobrepunha outra fase de ägua corrente, seguida da erosão local dos depösitos formados.

Das estruturas epigenëticas, foram notados os diastemas e os ca nais de recheio. Os primeiros, representam quebras na sedimentação de pouca duração. Os canais de recheio representam fases nas quais, apōs a deposição e consolidação dos sedimentos ocorriam äguas correntes pesadamente carregadas, erodindo os depósitos acima, e depositando então os materiais de textura e cores diferentes que constituíram os canais de recheio. 
CAPTTULO 111

METODOLOGIA

A obtenção dos dados e sua consequente manipulação e interpretação, para a confecção deste trabalho, foram possiveis com a adoção do seguinte procedimento metodológico:

- Exame da bibliografia pertinente;

- Viagem ao campo e coleta das amostras;

- Realização dos ensaios, testes e estudos, e obtenção de dados, os quais, visaram conseguir e compreender as propriedades de interesse ao trabalho.

\section{Exame da bibliografia existente}

Os trabalhos examinados constam da relação de referências, como é de praxe. Notam-se, pelas razões jä expostas, a escassez de títulos rela tivos ã geotecnia de rochas sedimentares brandas, e particularmente dos relativos aos arenitos Caiuä.

\section{Viagem ao campo e coleta de amostras}

Em visitas ao Pontal do Paranapanema, providenciou-se a coleta das amostras âs margens dos Rios Paranả e Paranapanema. As amostras coleta das foram dos tipos de blocos com formas irregulares e testemunhos de sondagens rotativas. Os primeiros foram obtidos em dois locais: em Porto Rosa na e a $16 \mathrm{~km}$ a montante deste local, sempre na margem esquerda do Rio Para nä. As sondagens rotativas foram executadas em 3 locais situados a $19,2 \overline{6}$ e $33 \mathrm{Km}$ aproximadamente a montante da confluência dos dois rios citados, e junto às margens do Paranapanema. Na figura 1, vêem-se os locais de amos tragem citados, aos quais, doravante serão referidos simplificadamente, a 


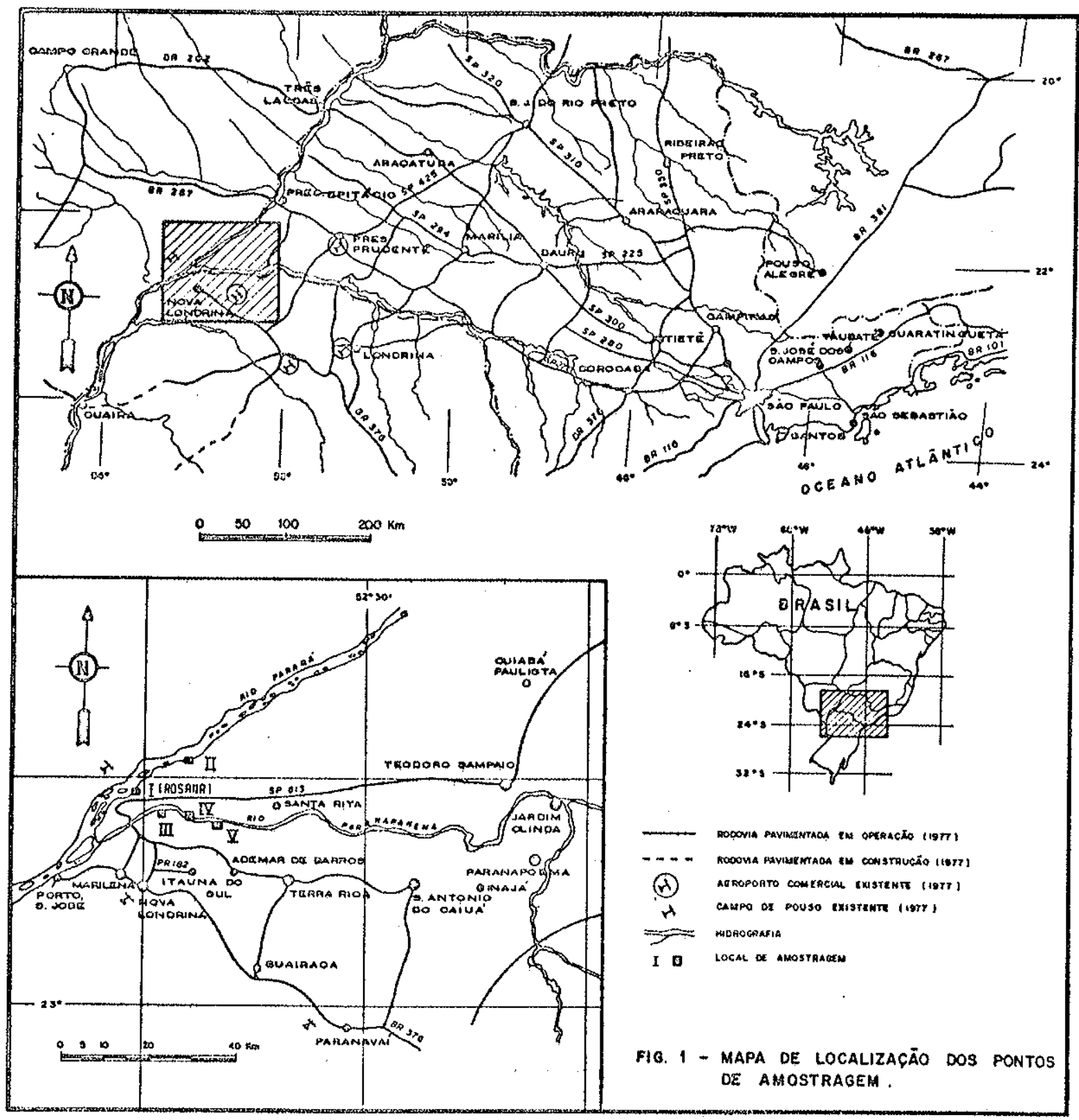


locais I (Porto Rosana) e 11 (16 km a montante de Porto Rosana), no Rio Pą ranä; e 111 , IV e V, no Rio Paranapanema. As sondagens foram do tipo rotativas, cujos testemunhos possuíam diâmetros de $86 \mathrm{~mm}$ ou $H_{w}$ e $N_{w}$ (respectivamente 54 e $76,2 \mathrm{~mm}$ ), sendo a perfuração executada com coroa de diamante e barrilete duplo-livre método cujos pormenores serão comentados em capitu lo específico, 0 s ensaios foram realizados no Laboratório Central de Engenharia Civil, de propriedade da Companhia Energêtica de São Paulo, em liha Solteira; no Instituto de Pesquisas Tecnolögicas de São Paulo e no Laboratório de Solos e Estradas do Departamento de Transportes da Faculdade de Engenharia da UNICAMP, em Limeira, todos os locais no Estado de São Paulo.

\section{Sistemätica para a caracterização das amostras}

Procurou-se individualizar, dentro do pacote dos Arenitos Caiuä, tipos que possuíssem certas características macroscōpicas comuns. Chamar-se-ã isto de "compartimentação do maciço", muito embora esta denominação envolva, na verdade, a consideração de um nümero muito maior de propriedades do que às que são aqui referidas.

0 pacote de arenito foi dividido simplificadamente em arenitos brandos, medianamente resistentes e resistentes. Os primeiros, são aqueles cuja totalidade do volume de amostra disponível ou parte dela e facilmente desagregävel pela pressão dos dedos; corresponderiam aos materlais que poderiam ser chamados, simplificadamente de "alteração de arenito", embora o termo alteração não seja de todo adequado, aqui; ou seja, trata-se de mate riais desagregados, total ou parcialmente, na parte superficial do pacote sedimentar. Os arenitos resistentes seriam aqueles que, alëm de não serem quebrados ã pressão dos dados, possuem bordas cortantes que podem ser desgastadas pelo corte de uma lâmina de aço, sendo dificilmente peneträvel pe la referida lâmina, não sendo possivel portanto, sulcä-lo profundamente;os medianamente resistentes seriam os que não se desagregam à pressão dos de dos, mas que podem ser profundamente sulcados com o canivete. No entanto, os dois ültimos tipos são sensíveis ao impacto do martelo, esfarelando-se. Vê-se que essa classiflcação corresponde aos "graus de coerência" propos" tos por Guidiclni, Oliveira, Camargo e Kaji (1972), na tabela nümero 1, sendo os tipos rochosos brando, medianamente re sistentes e resistentes correlacionäveis respectivamente aos niveis frlävel, pouco coerente e coerente.

Todos os tipos citados apresentam-se alnda friáveis, no sentido 
em que friável significa "suscetivel de se esfarelar e reduzir a fragmen-

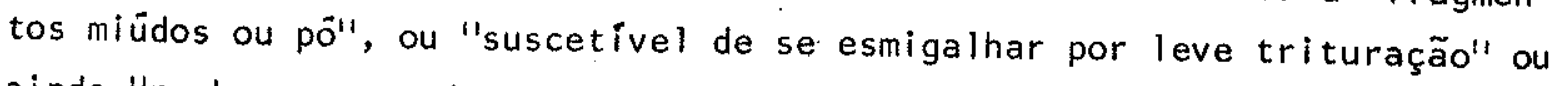
ainda "rochas que se desagregam facilmente" (Caldas Aulete, Dicionário Con temporâneo da Língua Portuguesa, 2 $\stackrel{a}{\text { E }}$ Edição Brasileira, 1964). Assim ē que os exemplares coletados, quando em contato uns com os outros, desagregamse a seco por atrito, sendo maior ou menor tal desagregabilidade em função dos teores de cimento e matriz, do tipo de cimento, e da superposição de fenômenos ligados ao intemperismo tropical sobre os arenitos em questão.

Tabela 1

Graus de coerência de rochas (Segundo

Guidicini, Oliveira, Camargo e. Kaji, 1972)

\begin{tabular}{|c|c|c|}
\hline Rocha & Símbolo & Características \\
\hline $\begin{array}{l}\text { Mui to } \\
\text { Coerente }\end{array}$ & C 1 & $\begin{array}{l}\text { - quebra com dificuldade ao golpe do martelo } \\
\text { - o fragmento possui bordas cortantes que resis } \\
\text { tem ao corte por lâmina de aço } \\
\text { - superfície dificilmente riscada por lâmina } \\
\text { de aço }\end{array}$ \\
\hline Coerente & C 2 & $\begin{array}{l}\text { - quebra com relativa facilidade ao golpe do } \\
\text { martelo } \\
\text { - ofragmento possui bordas cortantes que podem } \\
\text { ser abatidas pelo corte com lâmina de aço } \\
\text { - superficie riscável por lâmina de aço }\end{array}$ \\
\hline $\begin{array}{l}\text { Pouco } \\
\text { Coerente }\end{array}$ & C 3 & $\begin{array}{l}\text { - quebra facilmente ao golpe do martelo } \\
\text { - as bordas do fragmento podem ser quebradas pe } \\
\text { la pressão dos dedos } \\
\text { - a lâmina de aço provoca um sulco acentuado na } \\
\text { superfície do fragmento }\end{array}$ \\
\hline Friāvel & C 4 & $\begin{array}{l}\text { - esfarela ao golpe do martelo } \\
\text { - desagrega sob pressão dos dedos }\end{array}$ \\
\hline
\end{tabular}


Os arenitos com cimento carbonätico apresentam resistência variā vel dependendo da percentagem do cimento. Algumas dessas amostras podem apresentar-se impeneträveis à lâmina do canivete, enquanto outras não. 0 quadro 1 , resume o que foi dito, no que se refere à resistên cia qualitativa dos arenitos Caiuá.

Quadro 1

Critērios para a descrição dos Arenitos Caiuä quanto à dureza

\begin{tabular}{|c|c|c|}
\hline Denomi nação & Cimento & Dureza \\
\hline Resistente & $\begin{array}{l}\text { Limonítico } \\
\quad \text { e/ou } \\
\text { carbonätico }\end{array}$ & $\begin{array}{l}\text { Não pode ser riscável à pressão dos dedos. } \\
\text { Sulcos pouco profundos pela lâmina de aço. } \\
\text { Pode apresentar-se impeneträvel à mesma } \\
\text { quando houver concentração anormal de cimen } \\
\text { to carbonâtico, ou quando os processos de } \\
\text { ferruginização tenham sido intensos. }\end{array}$ \\
\hline $\begin{array}{l}\text { Medianamente } \\
\text { resistente }\end{array}$ & Limonítico & $\begin{array}{l}\text { Facilmente esculpivel com a lâmina de aço, } \\
\text { que provoca sulcos profundos na amostra. } \\
\text { Fragmentos dificilmente quebräveis pela } \\
\text { pressäo dos dedos. }\end{array}$ \\
\hline Brando & $\begin{array}{l}\text { Limonitico } \\
\text { âs vezes } \\
\text { carbonáticos }\end{array}$ & $\begin{array}{l}\text { Desintegra-se todo ou em parte à pressão } \\
\text { dos dedos. }\end{array}$ \\
\hline
\end{tabular}

Imperam na região os arenitos com cimentação limonitica de baixa resistência mecânica, que sofrem desagregação intensa quando submetidos à ciclagem acelerada ägua-estufa, como teremos oportunidade de comentar. Nos locais de amostragem 111 e $V$, o corpo de arenito tem uma espessura mínima de $30 \mathrm{~m}$ sob o leito do rio, entre as cotas 200 e 230. De um modo geral, pa rece constituído por dois tipos distintos. Na porção superior, ocorre o areni to vermelho-arroxeado, grosseiro, com estratificação cruzada millime-trica muito característica, cimentação limonítica, pouco resistente e que quebra com facilidade ao longo da estratificação. Este tipo evolui para formas mais brandas, muito friäveis e de cor avermelhada. Correspondem aos tipos medlanamente resistentes e brando, do quadro anterior. Esses tipos ocorrem atê a cota 215, sendo que daí, para baixo até o contato com o basalto, predomina o arenito mais fino, eventualmente siltico, marrom averme Ihado com microestratificação cruzada sub-horizontal irregular, e trechos quase maciços com cimentação limonítico carbonätica, incluindo-se no tipo 
resistente do quadro jä referido. Neste mesmo horizonte, ocorrem tambëm arenitos de estratificação cruzada. A separação entre esses dois tipos des critos não ë às vezes muito nítida.

A distinção entre arenitos com ou sem cimento carbonätico tambëm ė problemảtica, atravẽs de uma anälise visual. Veja-se por exemplo, as fo tos das amostras nümeros 2 e 8 , que representam respectivamente exemplares com cimentos não carbonätico, A aparência ê praticamente a mesma, inclusive no que se refere ao aspecto mosqueado, nos dois exemplares.

0 local de amostragem 11, é uma escavação de aproximadamente $45 \mathrm{~m}$ de comprimento por 15 de largura, e entre as altitudes de 243 e $256 \mathrm{~m}$. Ne la, aparecem os arenitos marrom-avermelhados e arroxeados, com textura clästica grosseira de granulação mëdia. Os grãos são arredondados, o cimen to limonitico e a matriz argilosa são pouco expressivos. 0 pacote é uma sequência de estratificação cruzada com inümeras co-sequências de estratos cruzados de diferentes tipos, com predomínio do tangencial. Os arenitos são dos tipos medianamente resistente e friävel.

As atitudes do diaclasamento, medidas neste local, foram, confor me a tabela 2:

Tabela 2

Atitudes do diaclasamento no Arenito Caiuá, lo cal de amostragem $\|$

\begin{tabular}{lcc}
\hline Direção & Mergulho & $\%$ de ocorrência, em 104 medidas \\
\hline $\mathrm{N} 70^{\circ} \mathrm{W}$ & $89^{\circ} \mathrm{NE}$ & 53,8 \\
$\mathrm{~N} 11^{\circ} \mathrm{W}$ & $87^{\circ} \mathrm{NE}$ & 20,2 \\
$\mathrm{~N} 17^{\circ} \mathrm{W}$ & $57^{\circ} \mathrm{NE}$ & 7,7 \\
$\mathrm{~N} 43^{\circ} \mathrm{E}$ & Vertical & 7,7 \\
$\mathrm{~N} 59^{\circ} \mathrm{E}$ & $77^{\circ} \mathrm{SE}$ & 5,8 \\
$\mathrm{~N} 20^{\circ} \mathrm{E}$ & $85^{\circ} \mathrm{NW}$ & 4,8 \\
\hline
\end{tabular}

As amostras foram divididas basicamente em quatro conjuntos:

Conjunto 1 - constituido por testemunhos das sondagens rotativas números SR-3 e SR-15, localizadas respectivamente nos locais de amostragem 111 e V, e por blocos com dimensões aproximadas de $30 \mathrm{~cm}$ ao longo do eixo maior, provenientes da escavação situada na margem esquerda do Rio Paranä, 
$16 \mathrm{~km}$ a montante de Rosana (local 11 , fotos nümeros $2,3,4,5$ e 6). Essas amostras foram numeradas de 1 a 12 (fotos nümeros $7,8,9,10,11,12$ e 13); lâminas delgadas, confeccionadas com as amostras nümeros $1,8,9$ e 10 (fotos nümeros $14,15,16,17,18,19,20$ e 21) são descritas no capítu lo seguinte.

Tambëm pertencentes a este conjunto säo as amostras numeradas de 45 a 68.

Conjunto 2 - blocos irregulares provenientes de afloramentos que ocorrem nas proximidades de Porto Rosana (local 1) e a $16 \mathrm{~km} \mathrm{a} \mathrm{montante}$ dessa cidade, na margem esquerda do Rio Paranã (local 11). As amostras são numeradas de 69 a 78 .

Conjunto 3 - amostras representadas por fragmentos de testemunhos das sondagens rotativas $S R-1,2,3,4,5,6,7$ e 8 , perfuradas no lo ca) 111 e $S R-15$, executada no local V. As sondagens $S R-3$ e 15 são as mes mas do conjunto 1 de amostras, jä referidas. 0 motivo pelo qual elas orig naram dois conjuntos de amostras, ê que a escolha dos fragmentos bem como os ensaios correspondentes, foram realizados em eppocas distintas. As amos tras desse conjunto são as de nümeros $13(S R-1) ; 14,15(S R-2) ; 16,17,18$, $19,20,21(S R-3) ; 22,23(S R-4) ; 24,25,26,27,28(S R-5) ; 29,30,31$, $32(S R-6) ; 33,34,35,36(S R-7) ; 37$ e $38(S R-8)$.

Conjunto 4 - amostras constituídas por testemunhos das sondagens $S R-23 A$ e SR-26A, executadas no local de amostragem IV, às margens do Rio Paranapanema. Seus nümeros são $39,40(S R-23-A) ; 41,42,43(S R-26-A)$ e 44 , esta proveniente de afloramento na margem esquerda do Rio Paranapanema, Io cal IV.

Acreditarse que os exemplares nümeros 1 a 12 representem efetiva mente as variações existentes no Arenito Caiuã, razão pela qual se julga como suficientes as descrições mais pormenorizadas, dos tipos referidos.

Os diferentes locais de amostragem são vistos na Figura 1 .

\section{Ensaios, testes e estudos}

Os ensaios físicos, testes e estudos realizados para se determinar e compreender as propriedades físicas e geo-mecânicas dos arenitos Caiuä, foram os seguintes: 


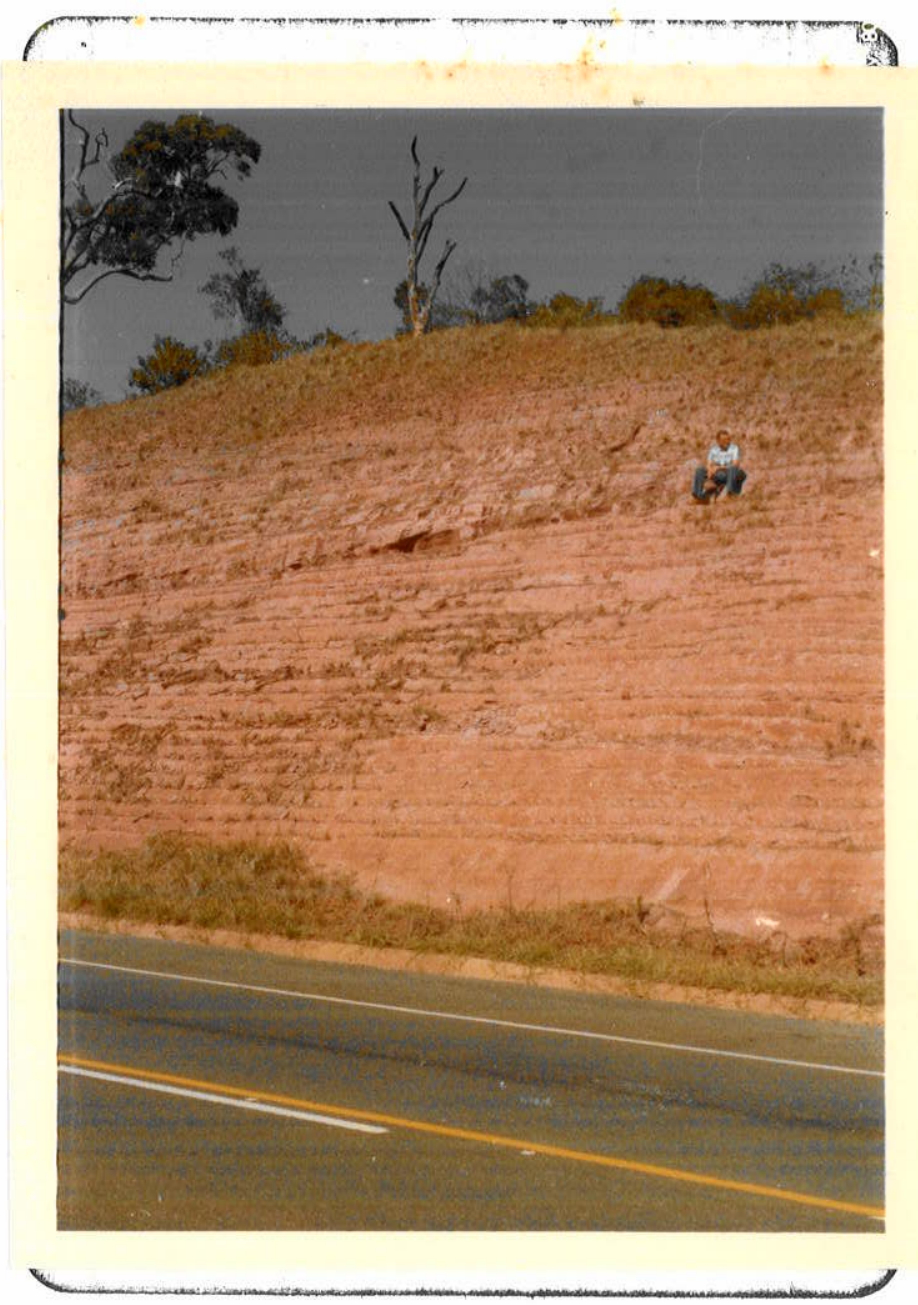

FOTO NO I

Afloramento de Arenito Caiuä. Estrada BR-376, trecho Maringä-Nova Londrina, proximidades de Paranavaí (PR). 


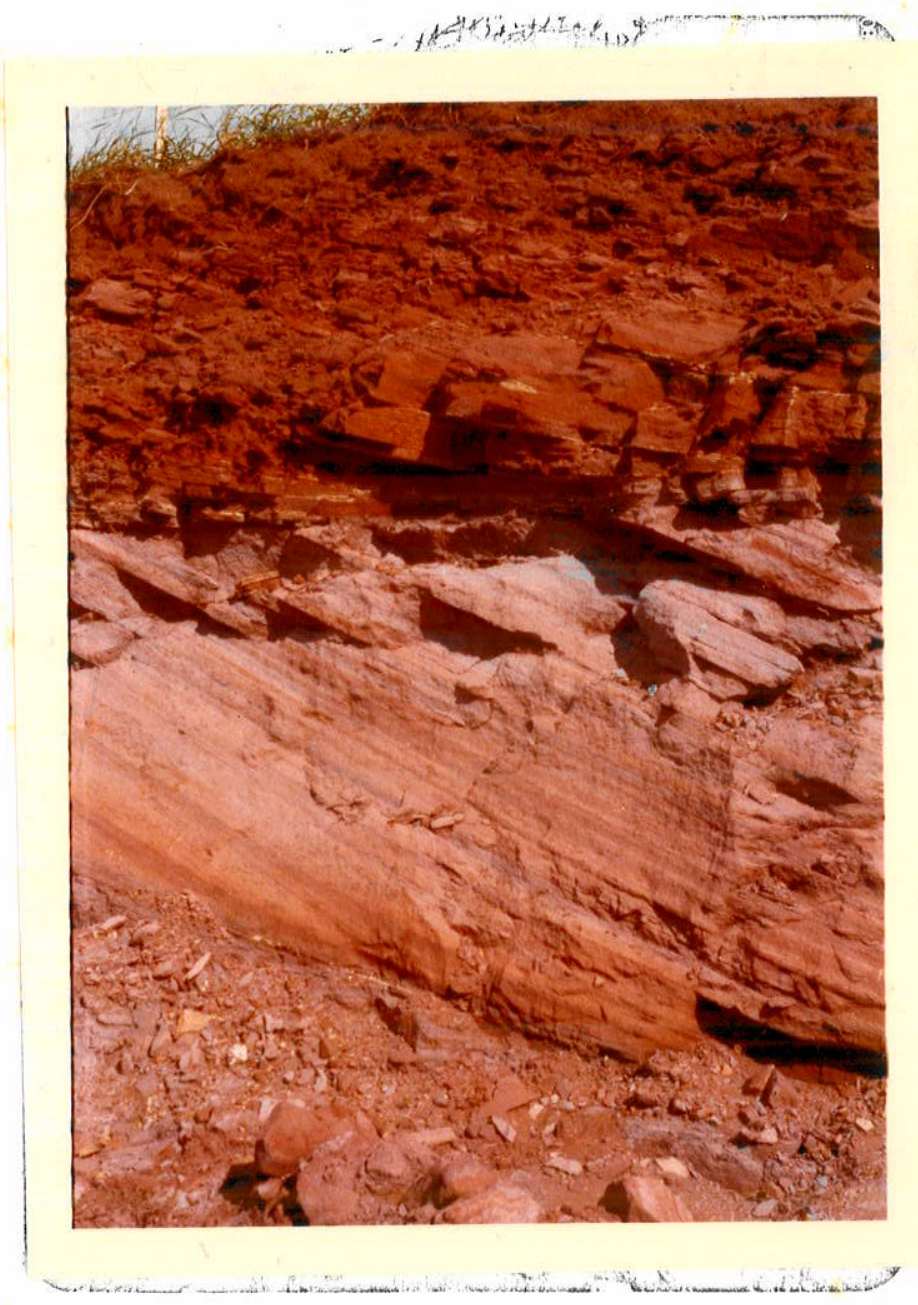

FOTO NO 2

Ponto de amostragem 11. Escavação situada $16 \mathrm{~km}$ a montante da cidade de Rosana, na margem esquerda do Rio Paranä. Arenito Caiuá avermelhado (superior) e violäceo (inferior); notam-se as estratificações cruzadas tangenciais. 0 fraturamento, na parte superior ë significativo, diminuindo em profundidade. A foto recobre aproximadamente $6 \mathrm{~m}$, na vertical. 


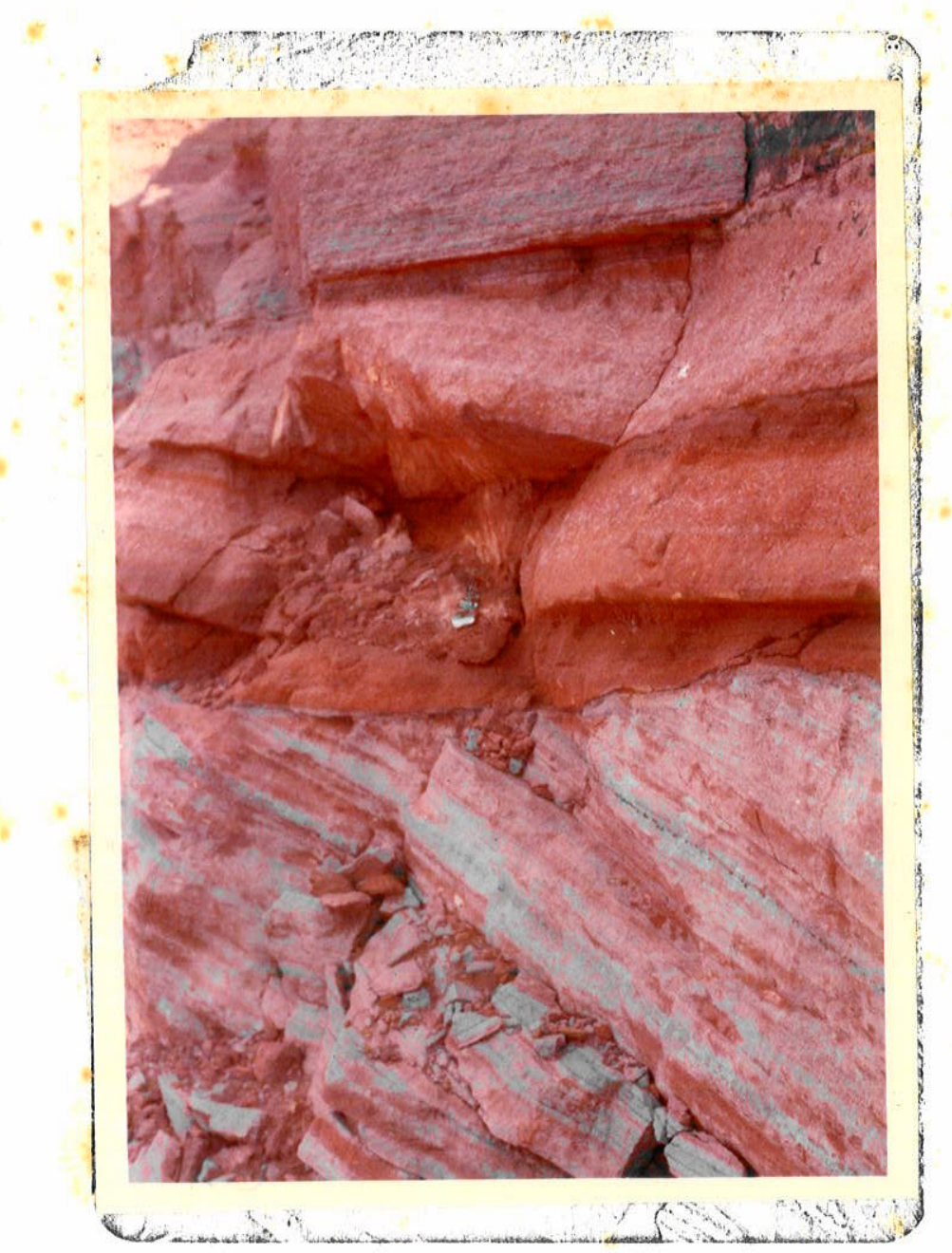

FOTO N. 3

Mesmo local da foto no 2. E vista uma sequência de estratificação cruzada com inúmeras co-sequências de estratos cruzados de diferentes tipos, predominando as tangenciais. 0 arenito é pouco fraturado, vendo-se um plano atravessando o pacote do canto superior direito para o inferior esquerdo, na foto. Hä tambẻm uma aparente dis:unção correspondente ao plano, onde o corpo de arenito superior avermelhado, trunca o corpo inferior, violäceo, com estratificação cruzada. 


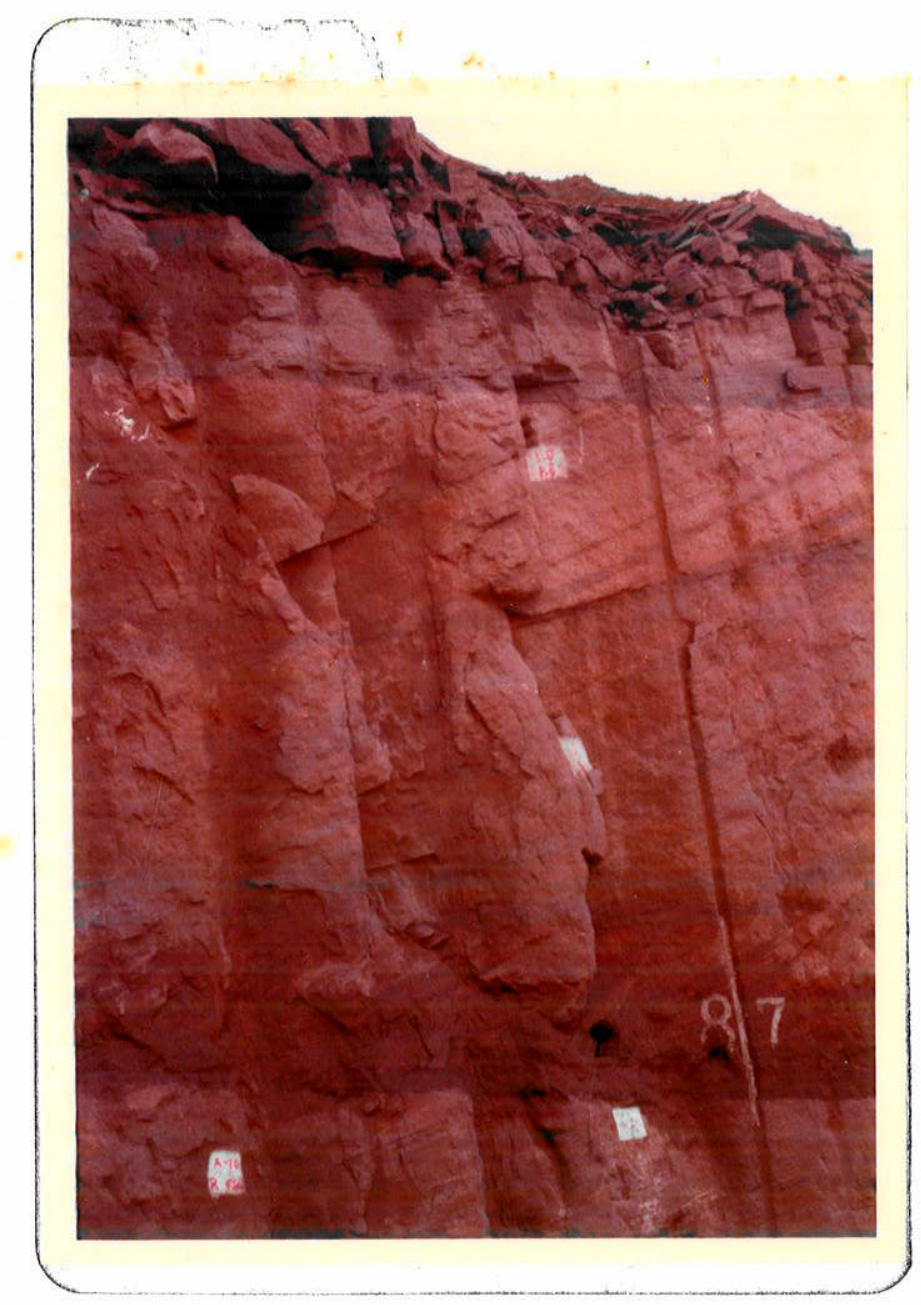

FOTO N: 4

Mesmo local das fotos n?s 2 e 3. Notam-se as mesmas feições das fotos referidas. Superiormente, ao fraturamento natural superpõe-se a quele devido às operações da escavação. No contato dos corpos inter mediärio e inferior, quase no extremo inferior da foto, hä sinais evidentes de percolação de ägua que corresponde às altitudes de 246 a $248 \mathrm{~m}$. A foto recobre uma seção vertical de mais ou menos $8 \mathrm{~m}$. 


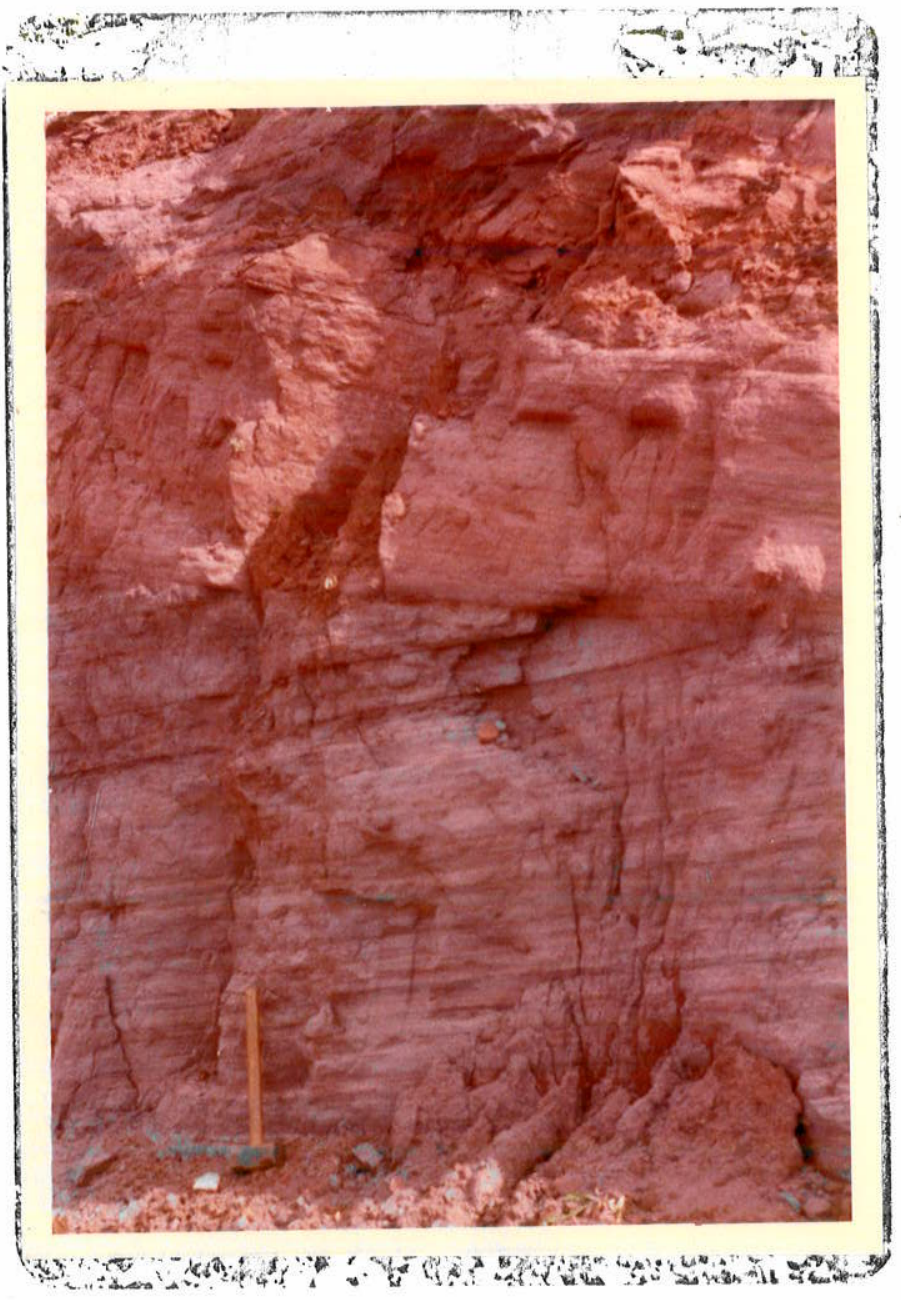

FOTO N 5

Mesmo local das fotos 2,3 e 4 . Repetem-se as feições jā descritas. 


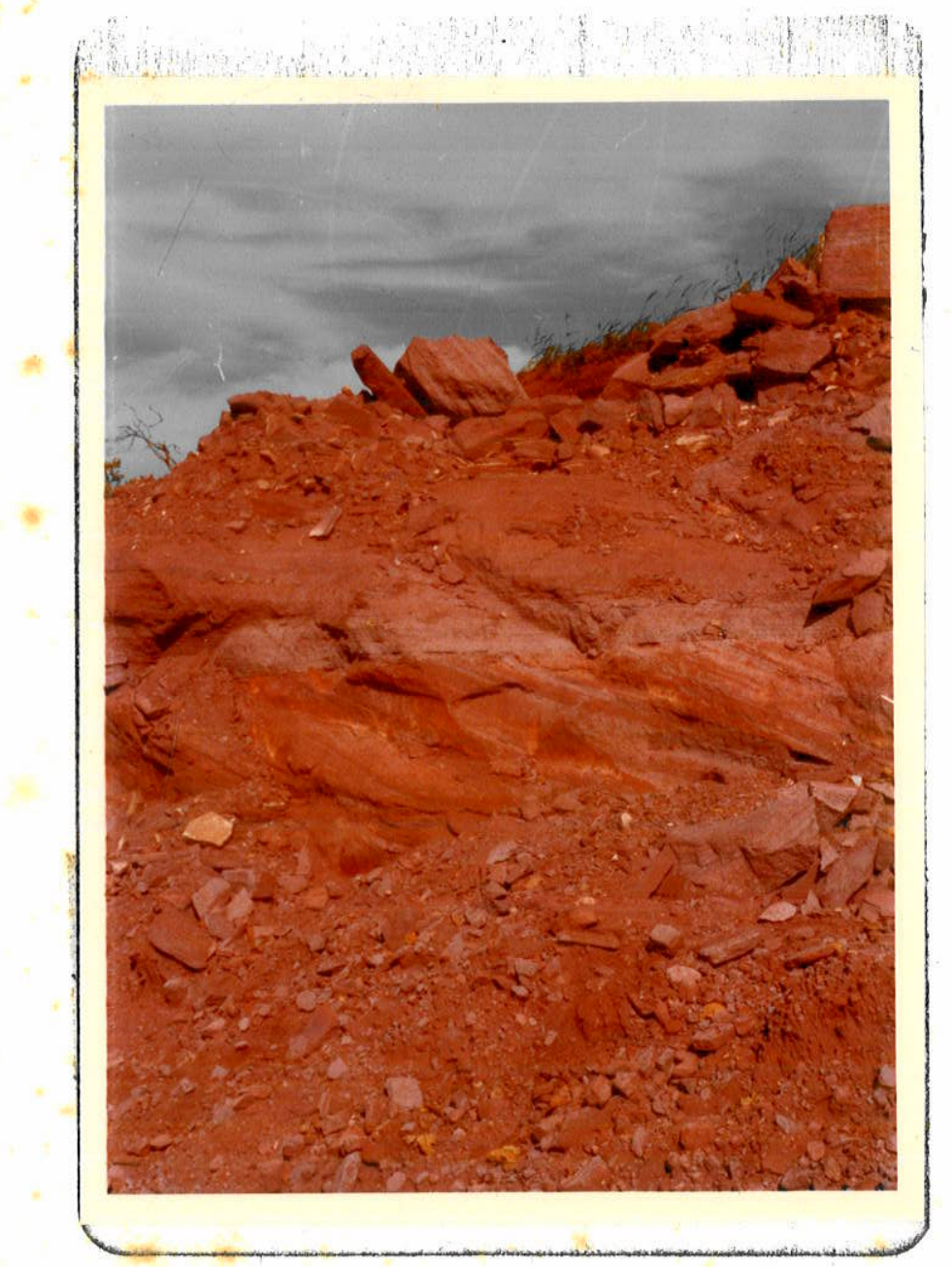

FOTO N․ 6

Ainda o mesmo local 11 de amostragem. Emboque da escavação, podendo-se avaliar o grau de friabilidade do arenito escavado. A foto recobre mais ou menos $6 \mathrm{~m}$ na vertical. 


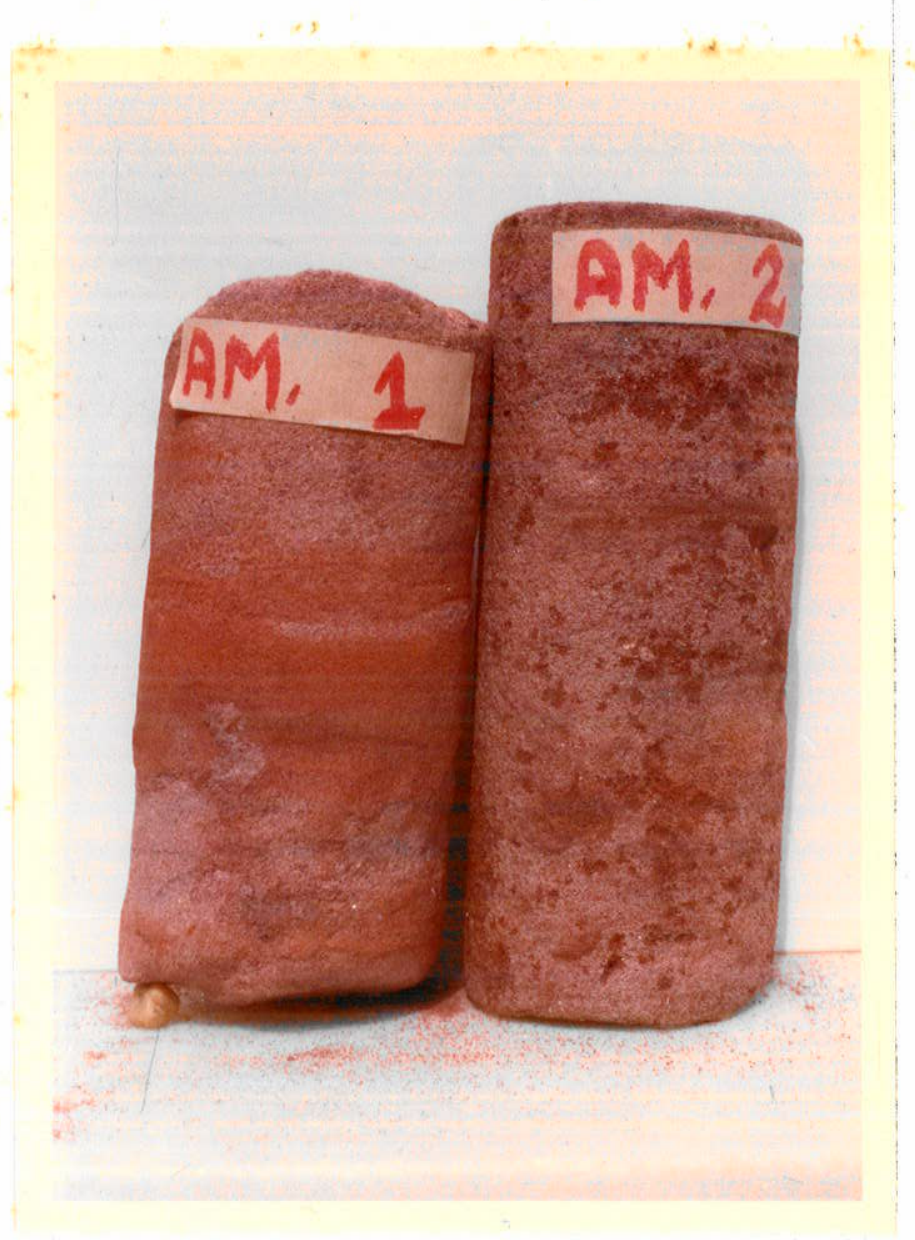

FOTO N. 7

AMOSTRA NO

PROFUNDIDADE

(m)
ALTITUDE

(m)

243,71
1
12,30

Arenito marrom arroxeado ou avermelhado, mëdio, textura clásticas gros seira, grãos arredondados, cimento limonítico, pouca matriz argilosa, manchas claras, violáceas disseminadas, correspondente a material mais grosseiro. Estratificação incipiente. Medianamente resistente e friävel.

AMOSTRA NO

\section{PROFUNDIDADE}

(m)

\section{ALTITUDE}

(m)

Arenito marrom avermelhado ou arroxeado, médio, textura clästica gros seira, grãos arredondados, cimento limonítico. Pouca matriz argilosa, sem estratificação. Com manchas escuras disseminadas e juntas brancas submilimëtricas. Medianamente resistente, friävel. 


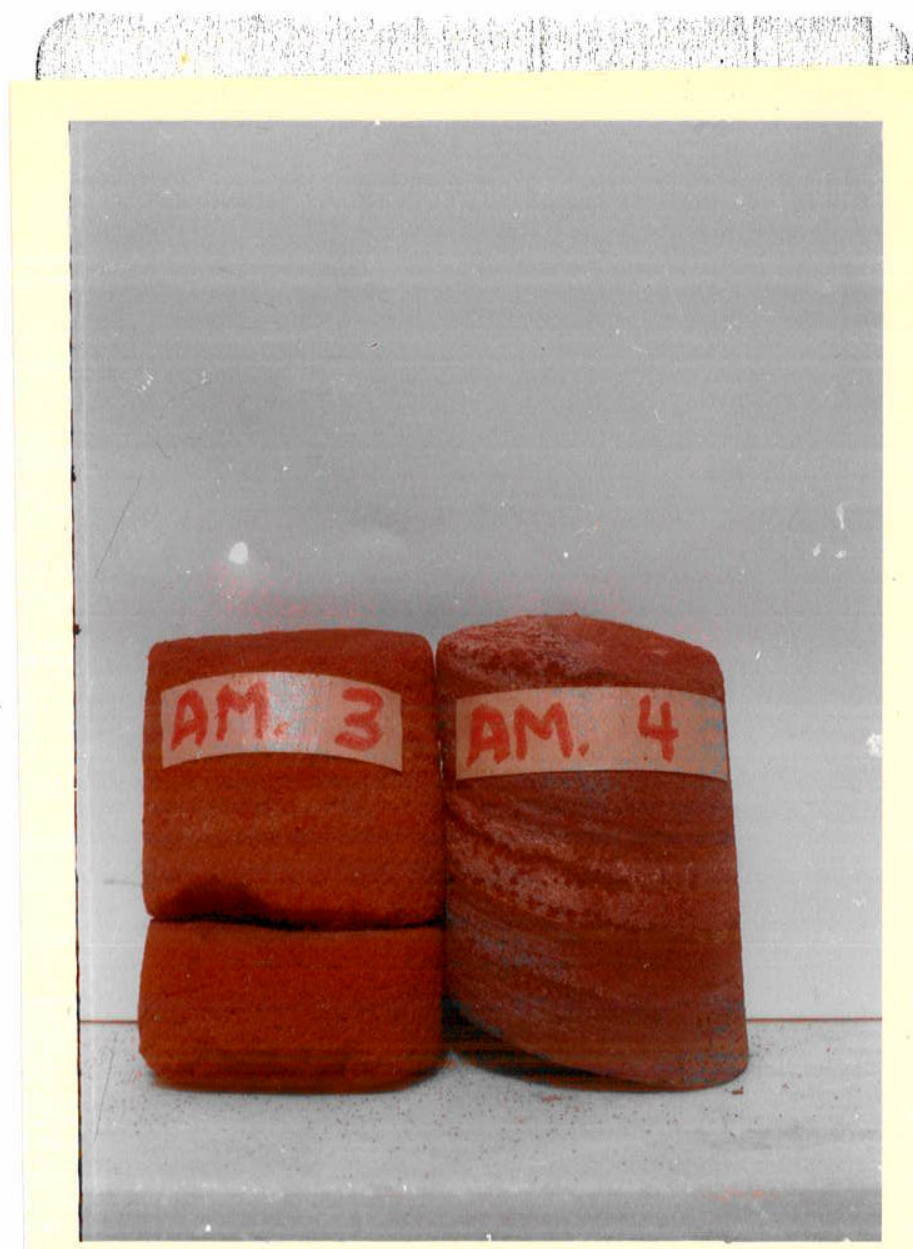

FOTO Nㅜ 8

AMOSTRA NO

PROFUNDIDADE

(m)

15,50
ALTITUDE

(m)

240,51

Arenito marrom-avermelhado mëdio, textura clästica grosseira, grãos arredondados, cimento limonítico. Pouca matriz argilosa, sem estratificação. Com numerosas pintas brancas submilimëtricas na amostra. Medianamente resistente, friảvel.

AMOSTRA N:

4

\section{PROFUNDIDADE}

(m)

15,75
ALTITUDE

(m)

240,31

Arenito marrom arroxeado, mëdio, textura clästica grosseira, grãos arredondados, cimento limonitico. Pouca matriz argilosa, estratificação milimëtrica a centimétrica. 0s estratos possuem diferentes co lorações, ou seja, marrom claro, marrom escuro ou violeta. Poucas pintas brancas submilimëtricas na amostra. Níveis de ferruginização coincidentes com certos estratos. Medianamente resistente, friävel. 


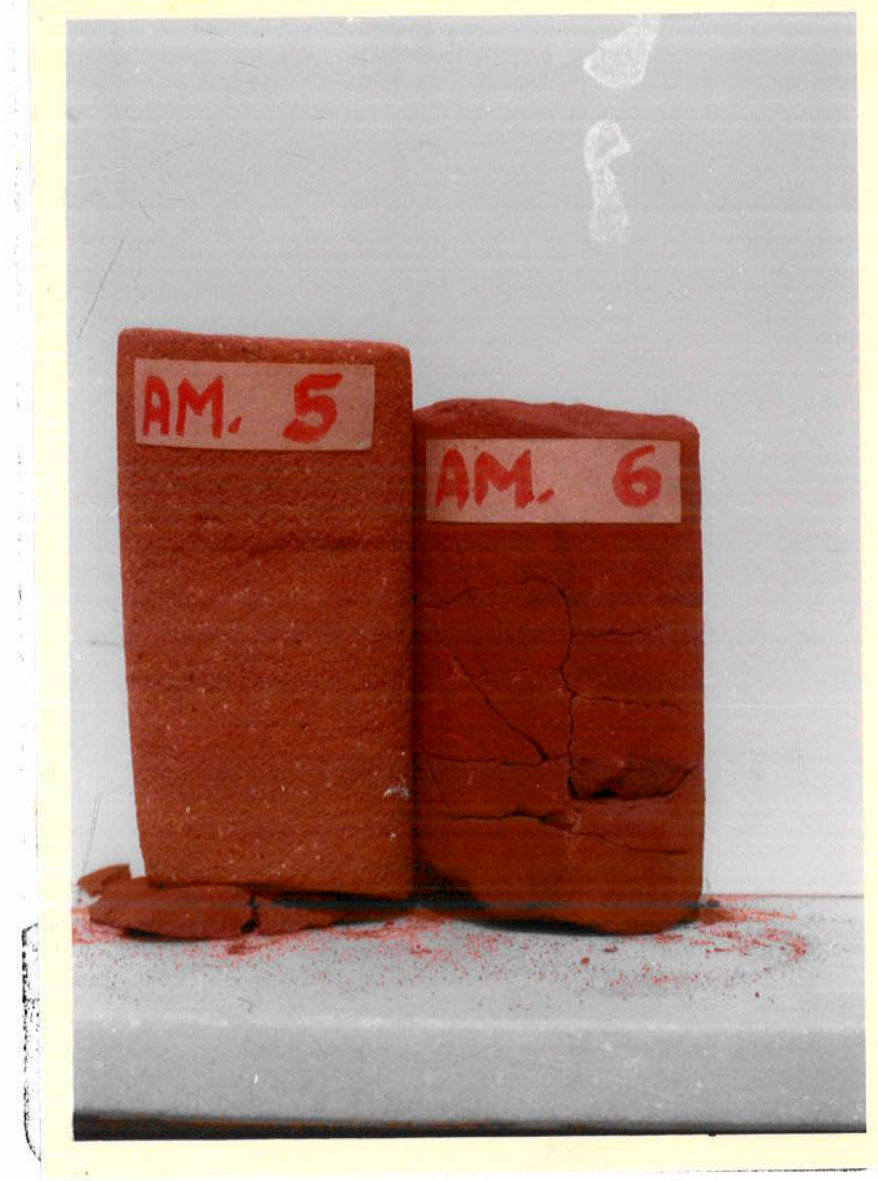

FOTO N․ 9

AMOSTRA N?

5
PROFUNDIDADE

(m)

9,00
ALTITUDE

$(\mathrm{m})$

232,03

Arenito marrom claro, mêdio, textura clästica grosseira, grãos arredondados. Pouca matriz argilosa, cimento limonítico. Sem estrati ficação, com numerosas pintas brancas milimëtricas disseminadas na amostra. Medianamente resistente, friävel.
AMOSTRA NO
PROFUNDI DADE
(m)
ALTITUDE
10,50
$(\mathrm{m})$
6

$$
10,50
$$$$
230,53
$$

Arenito marrom avermelhado, fino a mëdio, textura clästica grossei ra, grãos arredondados. Matriz argilosa em maior quantidade que nos tipos anteriormente descritos. Sem estratificação, cimento limonítico. Poucas pintas brancas submilimêtricas disseminadas. Medianamente resistente, pouco friävel. Notam-se fissuras devidas ao ressecamento do material argiloso presente. 


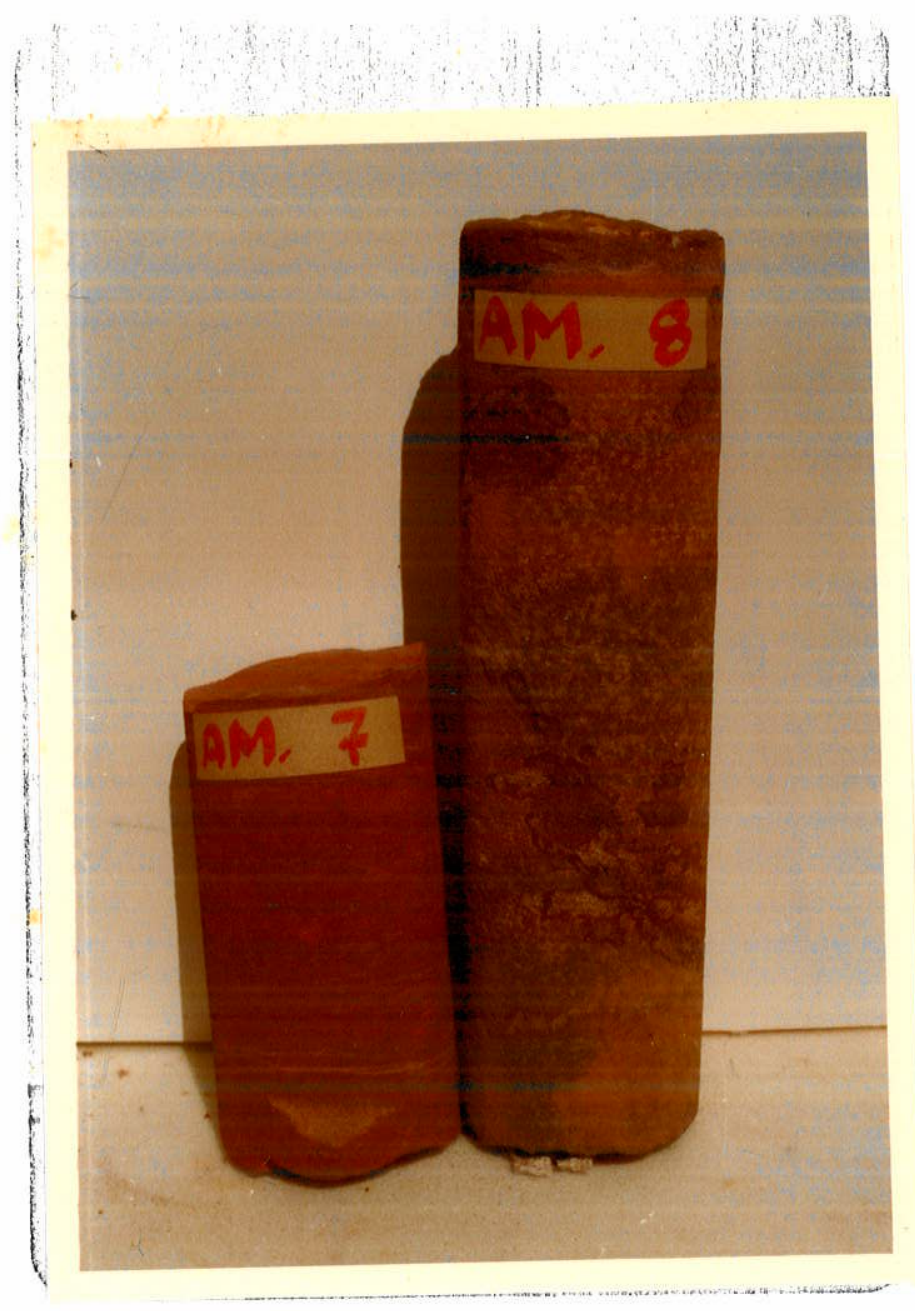

FOTO N ㅇ 10

AMOSTRA N?

7
PROFUNDIDADE

(m)

28,70
ALTITUDE

(m)

213,33

Arenito marrom avermelhado, fino a mëdio. Textura clästica, grosseira, grãos arredondados, cimento limonítico. Matriz argilosa em quantidade significativa. Sem estratificação, resistente, pouco friävel.

AMOSTRA NO

8

\section{PROFUNDIDADE}

(m)

32,60
ALTITUDE

(m)

208,43

Arenito marrom avermelhado, mẻdio. Textura clästica grosseira, grãos arredondados, cimento limonítico e carbonätico. Estratificação quase ausente. Aspecto semelhante a uma brecha, parecendo que fragmentos de material marrom escuro foram englobados na amostra. Concentrações de material mais claro, parecendo manchas, centimëtricas, disseminadas e mostrando alguma orientação. Resistente, pouco friävel. 


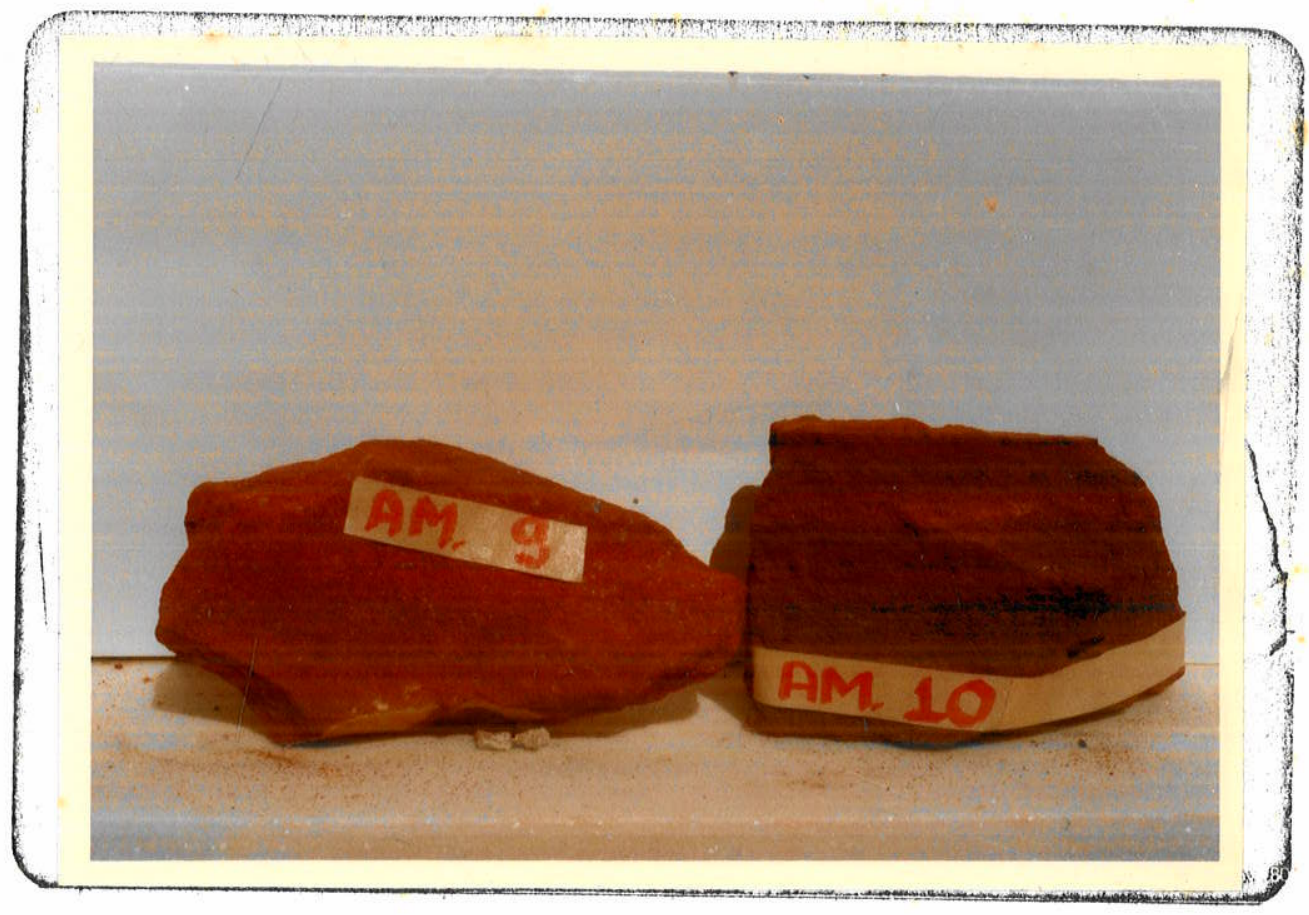

FOTO N: 11

AMOSTRA N: ALTITUDE APROXIMADA

(m)

Arenito marrom avermelhado, com textura clästica grosseira, mëdio. Grãos arredondados, cimento limonitico, pouca matriz argilosa, sem estratificaçäo. Numerosas pintas brancas milimëtricas dispersas na amostra. Medianamente resistente, friảvel.

AMOSTRA NO ALTITUDE APROXIMADA

(m)

10

245

Arenito marrom arroxeado, mëdio, com textura clästica grosseira. Gräos arredondados, cimento limonitico, pouca matriz argilosa, estratificado. Medianamente resistente, friävel. 


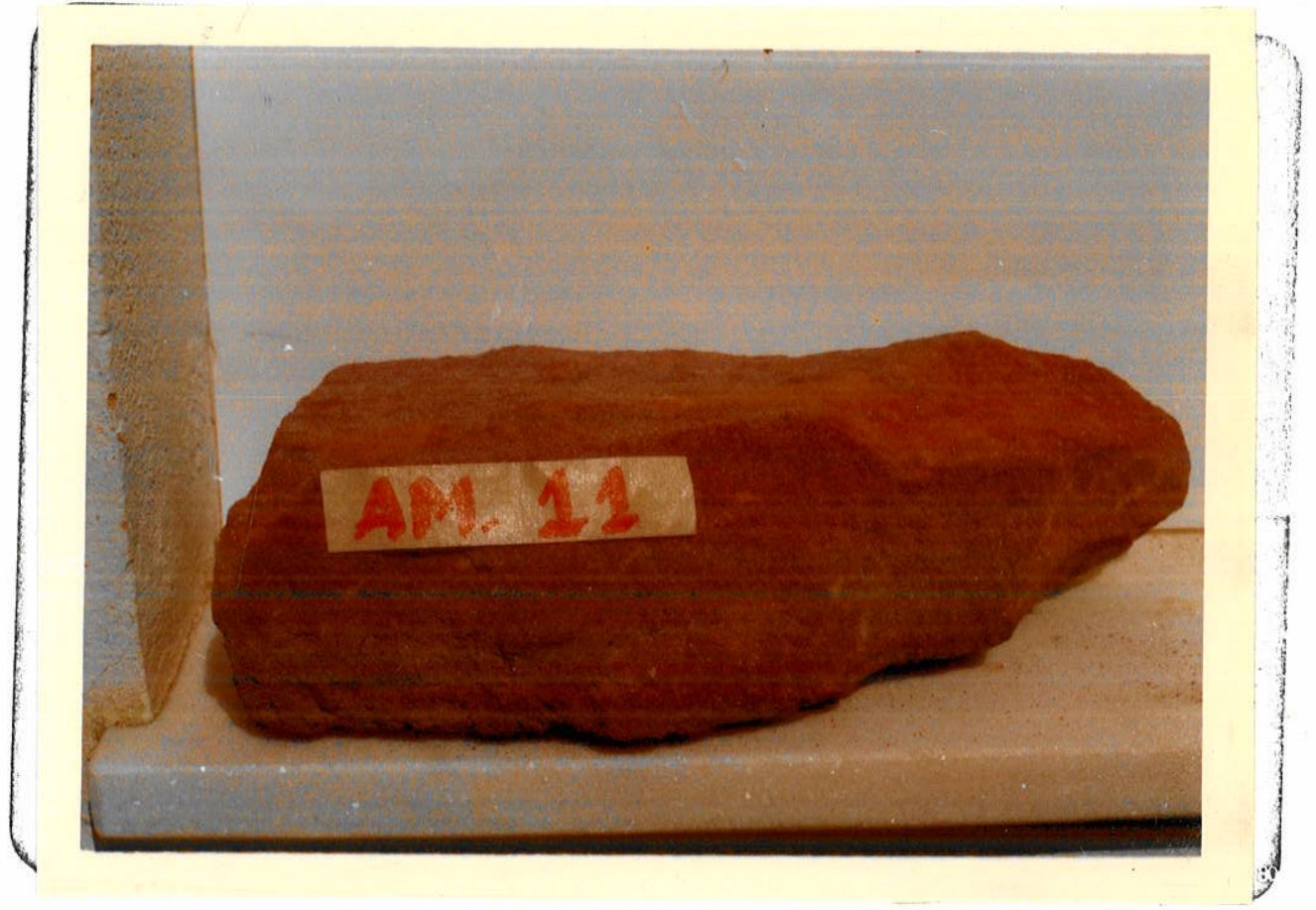

FOTO NN 12

AMOSTRA N:

ALTITUDE APROXIMADA

(m)

11

245

Arenito marrom arroxeado mëdio, textura clästica grosseira. Cimento limonitico, escassa matriz argilosa. Numerosas pintas brancas disseminadas, sem estratificação. Medianamente resistente, friävel. 


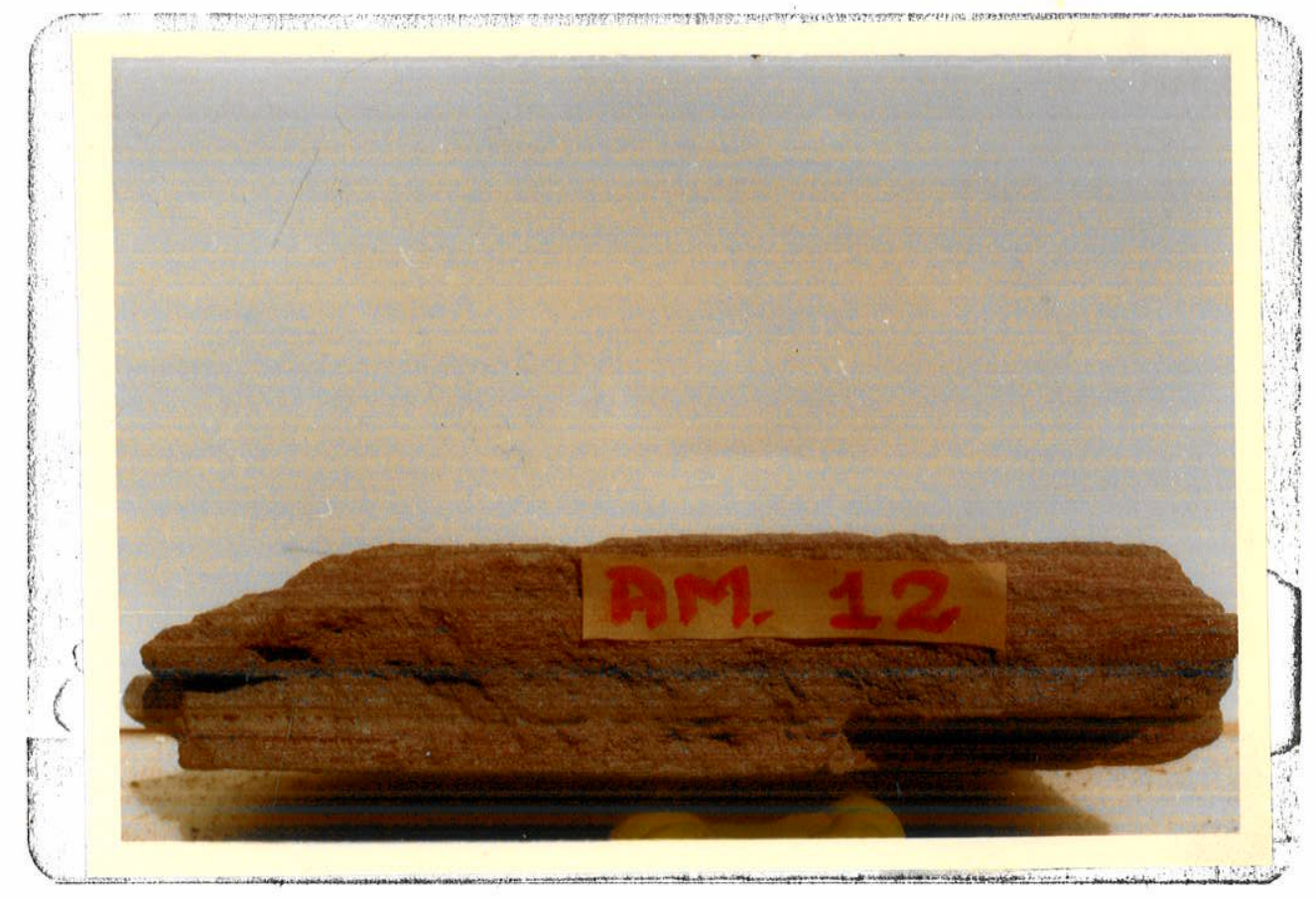

FOTO N 13

AMOSTRA No

ALTITUDE APROXIMADA

(m)

12

245

Arenito marrom arroxeado, mëdio, textura clástica grosseira. Cimento limonítico, escassa matriz argilosa. Estratificação milimêtrica, resistente, friävel. 


\section{Ensaios Físicos}

Granulometria

Densidade dos grãos

Massa especifica aparente seca

Absorção d'ägua

Porosidade aparente

Porosidade real

Porcentagem de saturação dos vazios

Estudos Petrogräficos

Seçōes delgadas

Testes de Durabilidade

Ciclagem Natural

Ciclagem âgua estufa (acelerada)

Ensaios de Resistência

Abrasão Los Angeles

Impacto Treton

Compressão simples e deformabilidade

Compressão triaxial

Ensaios de Permeabilidade

$\bar{A}$ àgua.

$\mathrm{Na}$ tabela 3 , vêem-se relacionados os conjuntos de amostras, a numeração destas, sua proveniência e os ensaios com elas realizados; e no Quadro 2, a relação nominal dos ensaios.

\section{Estudos petrogräficos - Seções delgadas}

Com essa metodologia, visou-se a descrição detalhada no microscô pio petrogräfico do material de interesse bem como estabelecer os vínculos genéticos entre a mineralogia e petrografia dos arenitos e seu ambiente de deposição.

As seções delgadas estudadas foram confeccionadas segundo a tecnologia usual en Petrografia, e que consiste, simplificadamente em cortar a seco uma pequena fatia $(0,5 \mathrm{~cm}$ de espessura por $2,0 \mathrm{~cm}$ de largura) da ro 
Tabela 3

Designação das amostras, sua procedência e ensaios realizados

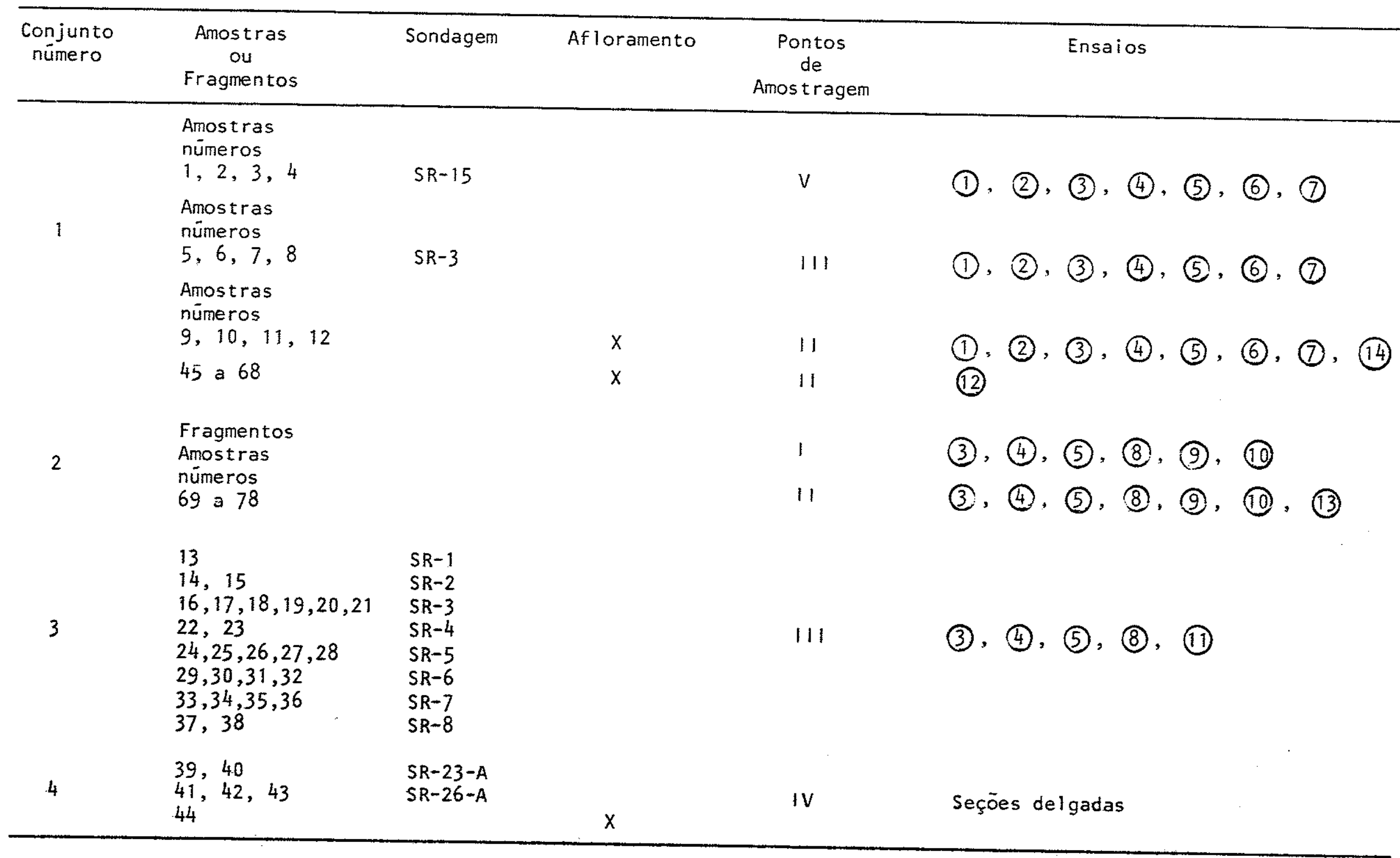


Quadro 2

Relação nominal dos ensaios referidos na Tabela 2
(1) - Granulometria
(2) - Densidade dos grãos
(3) - Massa especifica aparente seca
(4) - Absorção d'àgua
(5) - Porosidade aparente
(6) - Porosidade real
(7) - Porcentagem de saturação dos vazios
(8) - Durabilidade (ciclagem)
(9) - Resistência ao Impacto Treton
(10) - Resistência à Abrasão Los Angeles
(11) - Compressão simples e deformabilidade
(12) - Compressão triaxial
(13) - Permeabilidade à água 
cha, e cozinhä-la com bälsamo, que a envolverä como uma película, o que darà ao pequeno fragmento uma maior resistência.

A seguir, procede-se ao polimento do mesmo com carborundum gros so, colamse numa placa de vidro e faz-se novo polimento, atẻ que fique na espessura desejada $(0,03 \mathrm{~mm})$. No material assim preparado limpa-se o exces so de cola com uma faca ou mesmo com âlcool, acrescentando-se mais uma ca mada de bâlsamo sobre a amostra e leva"se ao fogareiro, ã uma temperatura de 40 a $50^{\circ} \mathrm{C}$, por duas ou três horas, colando-se finalmente a lamínula que è uma pequena placa de vidro, de espessura normalmente igual a $0,03 \mathrm{~mm}$ ), sobre o material preparado como descrito acima.

As seções delgadas estão descritas nas fotos de nümeros 14 a 27 .

Ensaios físicos

\section{Granulometria}

Inicialmente foi necessärio executar o destorroamento das amos tras. Ele consiste em desintegrar a mesma com uma mão de gral de louça, no almofariz. Para algumas amostras, foi necessärio que fossem deixadas algum tempo imersas em ảgua para em seguida se proceder o destorroamento, jä que a seco não foi possível fazê-lo. Essas amostras foram as de nümeros 1,2 e 8. Não se conseguiu desagregar as amostras 4 e 7 nem da maneira descrita. A solução foi a de raspar as mesmas numa grosa de marceneiro.

$\mathrm{Na}$ determinação das diversas frações granulomëtricas, componen tes do Arenito Caiuã, usou-se o mëtodo MB-32/88, da Associação Brasileira de Normas Técnicas. Consiste tal mëtodo, em ensaiar-se a fração grosseira dos solos por peneiramento, e a fração fina por sedimentação, diferindo daquele normalmente empregado em Sedimentologia, onde se usa, para a fração fina, o mëtodo da pipetagem.

Para a execução do ensaio, usa-se peneirar a parte grossa do so lo, cujo limite inferior é representado pelo diâmetro $0,074 \mathrm{~mm}$, na sêrie de peneiras descritas na tabela 4. 
Tabela 4

Sërie de peneiras empregadas no peneiramento da fração grossa do solo

\begin{tabular}{cc}
$\begin{array}{c}\text { Peneira } \\
\text { nümero }\end{array}$ & $\begin{array}{c}\text { Abertura da malha } \\
(\phi, \mathrm{mm})\end{array}$ \\
\hline 4 & 4,760 \\
10 & 2,00 \\
16 & 1,190 \\
30 & 0,590 \\
50 & 0,297 \\
100 & 0,149 \\
200 & 0,074 \\
\hline
\end{tabular}

Apös o peneiramento, são pesadas as quantidades retidas em cada peneira $\left(P_{i}\right)$ e calcula-se a percentagem retida numa peneira pela relação

$$
\frac{P_{i}}{P} \times 100
$$

sendo $P=$ peso total da amostras seca. A percentagem retida acumulada em peso atë a peneira de ordem i ë calculada por:

$$
\begin{aligned}
& i \\
& i
\end{aligned} \frac{P_{i}}{P} \times 100
$$

Conhecendo-se as percentagens acumuladas dos pesos retidos em ca da peneira, pode-se traçar o gräfico "percentagens acumuladas" em ordenadas e "logaritmo das aberturas das peneiras (ou dos diâmetros dos grãos)" em abcissas.

No ensaio de sedimentação, usamse a amostra que passa na peneira nümero 10 (aproximadamente $50 \mathrm{~g}$ ) em uma suspensão com ägua destilada atë um volume de $1000 \mathrm{~cm}^{3}$.

Para evitar a floculação do material fino, misturarse um deflocu lante, o hexametafosfato de södio, que provou ser o mais eficaz. A quantidade deste produto foi de $45,7 \mathrm{~g}$ por litro de ägua destilada, solução esta que apresentou $\mathrm{pH}$ entre 8 e 9 e uma densidade de 5,5. 
Homogeneizada a solução, coloca-se nela um densímetro graduado, que possibilita o conhecimento da densidade da solução, em tempos espaçados.

Considerando-se a solução à uma profundidade $\underline{Z}$ apōs um tempo $\underline{t}$ qualquer, a velocidade $\underline{v}$ de uma partícula de diâmetro $\underline{0}$ que percorreu distância vertical $\underline{Z}$, será de acordo com a lei de Stokes:

$$
D=\sqrt{-\frac{18 \mu}{\delta-\gamma a} \frac{z}{t}}
$$

onde,

$\mu=$ viscosidade da ägua, em ${\mathrm{g} \mathrm{s} / \mathrm{cm}^{2}}^{2}$

$\delta=$ peso específico dos sôlidos $\mathrm{em} \mathrm{g} / \mathrm{cm}^{3}$

$\gamma_{a}=$ peso específico da ägua, em $\mathrm{g} / \mathrm{cm}^{3}$

Supondo-se que a densidade da solução apös o tempo $\underline{t}$ varie nearmente com a profundidade, demonstra-se que a leitura do densímetro è a densidade da suspensão na altura do centro do volume do seu bulbo.

Densidade dos grãos

Para a sua determinação, adota-se normalmente a Norma MB-28, da Associação Brasileira de Normas Técnicas.

Para tanto, usam-se $50 \mathrm{~g}$ de solo que passa na peneira $10 \quad(2,00$ $\mathrm{mm}$ ) e picnômetros (frascos de vidro), de $50 \mathrm{ml}$.

Inicialmente, obtêm-se o peso seco $P$ do material utilizado. A seguir, este ë colocado no picnômetro e coberto com ägua destilada atē aproximadamente $1,5 \mathrm{~cm}$ acima da sua superficie. Faz-se o vãcuo durante 15 minutos, retirando-se todo o ar da amostra. Completa-se com ägua destillada atê o traço de referência, no picnômetro. Determina-se o peso do picnôme tro + solo + ägua $\left(\mathrm{P}_{2}\right)$. Retira-se o solo, completa-se o volume de água e pesa-se o picnômetro + ägua $\left(P_{1}\right)$. A densidade dos grãos é dada pela fórmu la

$$
\gamma_{s}=\frac{P}{p_{1}+P-p_{2}}
$$


onde,

$$
\begin{aligned}
& P=\text { peso seco do material utilizado } \\
& P_{1}=\text { peso do picnômetro }+ \text { água } \\
& P_{2}=\text { peso do picnômetro }+ \text { ägua }+ \text { solo }
\end{aligned}
$$

Foram ensaiadas amostras pertencentes ao Conjunto 1, tambëm destorroadas como para os ensaios de Granulometria.

\section{Massa especifica aparente seca}

Usou-se o mëtodo IPT-M 47, que consiste no seguinte:

a) Corpos de prova, de dimensões preferentemente entre 2 e $3^{\prime \prime}$, săo colocados em estufa com temperatura entre 100 e $110^{\circ} \mathrm{C}$, durante 24 horas.

b) 0s corpos de prova säo a seguir resfriados em ambiente seco e pesados (peso $\mathrm{P}_{1}$ ).

c) A seguir, são imersos em ägua durante 48 horas.

d) Completo o tempo de imersão, os corpos de prova são pesados com as suas superfícies enxutas por um pano absorvente (peso $\left.P_{2}\right)$ :

e) Novamente são pesados submersos em ägua (peso $\mathrm{P}_{3}$ ),

A massa especiffica aparente seca é calculada pela förmula:

$$
\gamma_{\text {as }}=\frac{P_{1}}{P_{2}-P_{3}}
$$

\section{Absorção d'ägua}

Realizada segundo o método IPT-M-47. Determinou-se, para tanto:

a) Peso das amostras de dimensões entre $2^{\prime \prime}$ e $3^{\prime \prime}$, apōs imersas em ägua por 48 horas e enxugados por um pano absorvente $\left(P_{2}\right)$.

b) Peso das mesmas amostras após colocadas em estufa à temperatú ras entre $100^{\circ}$ e $110^{\circ} \mathrm{C}$, durante 24 horas e resfriados em am biente $\operatorname{seco}\left(P_{1}\right)$. 
A absorção è clada pela fórmula

$$
A b=\frac{P_{2}-P_{1}}{P_{1}} \times 100
$$

Porosidade aparente

Para sua realização, forarn necessärias as seguintes determinações :

a) Peso das amostras de dimensões entre $2^{\prime \prime}$ e $3^{\prime \prime}$, apös colocadas em estufa á temperaturas entre 100 e $110^{\circ} \mathrm{C}$ durante 24 horas e resfriadas em ambiente seco $\left(P_{1}\right)$.

b) Peso das mesmas amostras apös imersas em ägua por 48 horas e enxugadas por um pano absorvente $\left(P_{2}\right)$.

c) Peso das mesmas amostras submersas em ägua $\left(P_{3}\right)$.

A porosidade aparente ë definida por

$$
P_{a}=\frac{P_{2}-P_{1}}{P_{2}-P_{3}} \times 100
$$

\section{Porosidade real}

Trata-se de um parâmetro obtido atravës da relação

$P_{r}=\frac{P_{2}-P_{3}-\frac{P_{1}}{\gamma_{a s}}}{P_{2}-P_{3}} \times 100=\left(1-\frac{\gamma_{\text {as }}}{\gamma_{s}}\right) \times 100$

onde,

$\gamma_{\text {as }}=$ Massa especifica aparente seca do material

$\gamma_{S}=$ Densidade dos grãos

$P_{1}=$ Peso das amostras de dimensões entre $2^{\prime \prime}$ e $3^{\prime \prime}$, apōs colocadas em estufa à temperatura entre 100 e $110^{\circ} \mathrm{C}$, durante 24 horas e resfriadas em ambiente seco.

$P_{2}=$ Peso das mesmas amostras após imersas em ägua por 48 horas e enxugadas por um pano absorvente. 
$P_{3}=$ Peso das mesmas amostras submersas em ägua.

Este parâmetro foi calculado para amostras do Conjunto 1 .

\section{Porcentagem de Saturação dos Vazios}

São necessärios, para a sua determinação, o conhecimento dos seguintes parâmetros:

$$
\begin{aligned}
& P_{a}=\text { Porosidade aparente } \\
& P_{r}=\text { Porosidade real } \\
& E \text { calculada pela seguinte relação; }
\end{aligned}
$$

$$
S=\frac{P_{a}}{P_{r}} \times 100
$$

Ensaios de durabilidade

\section{A durabilidade de rochas}

0 tema em questão tem representado uma grande parcela da preocupação de estudiosos com atividades relacionadas ao campo dos materiais de construção.

Não se entrarä aqui em considerações relativas ã dinâmica do intemperismo, por entender que escapa aos propósitos do trabalho, mas sim se abordarä brevemente aspectos concernentes aos esforços desenvolvidos para - estabelecimento de critérios quantitativos dos graus de alteração das ro chas.

De uma maneira geral, estä estabelecido que o concel to de grau de alteração ẽ relativo, podendo uma rocha ser comparada com outra porção da mesma rocha que possua outro grau de alteração, ou comparando-se os graus de alteração de duas rochas diferentes.

Hamrol (1961) propôs, um conceito para grau de alteração de rochas como sendo "um certo volume de uma dada rocha ê mais alterado que um outro volume da mesma rocha, se as características mecânicas da primeira são mais baixas". 0 mesmo pesquisador enunciou ainda, na mesma ëpoca, o 
conceito de "alteração potencial" ("alterabilitê" ou "weatherability"), se gundo o qual "uma rocha ë mais alterävel que outra rocha, se, ambas tendo sido sujeitas aos mesmos agentes de intemperismo durante o mesmo tempo, o grau de alteração ë mais avançado na primeira". Notarse, portanto, uma cla ra tentativa de vincular os estados de alteração das rochas às suas propriedades mecânicas, o que de certo modo representa um consenso que norteia as pesquisas relativas ao assunto em questão.

Do ponto de vista mineralögico ou geoquímico, um certo volume de rocha é considerado mais alterado que um outro volume da mesma rocha se apresentar uma porcentagem de minerais mais alterados, e em consequência, uma maior quantidade de minerais de alteração.

Reiche, em 1943, anunciou o seu "índice de alteração" destinado a expressar numericamente o estado de alteração químico ou geoquímico de uma rocha, como sendo

$$
\frac{\text { moles }\left(\mathrm{Na}_{2} \mathrm{O}+\mathrm{K}_{2} \mathrm{O}+\mathrm{CaO}+\mathrm{MgO}-\mathrm{H}_{2} \mathrm{O}\right)}{\text { moles }\left(\mathrm{Na}_{2} \mathrm{O}+\mathrm{K}_{2} \mathrm{O}+\mathrm{CaO}+\mathrm{MgO}+\mathrm{SiO}_{2}+\mathrm{Al}_{2} \mathrm{O}_{3}+\mathrm{Fe}_{2} \mathrm{O}_{3}\right)} \times 100
$$

Para um mesmo tipo de rocha, de um mesmo maciço, a relação acima serä tanto menor quanto mais alterado for o volume de rocha considerado.

No que se refere ãs implicações da durabilidade de rochas como materiais de construção e em campos correlatos, pode-se enumerar fundamentalmente quatro efeitos:

1 - Diminuição da resistência com ou sem a produção de finos;

2 - Varlações nas características mecânicas de deformação e deformabilidade:

3 - Variação na porosidade e permeabilidade, consequentemente na es tanquei dade;

4 - Diminuição nas características de aderência ou adesividade seja a ligantes hidräulicos como betuminosos.

Aires-Barros vincula a alteração das rochas a fatores intrínser cos e extrinsecos a ela.

Os fatores intrinsecos são a natureza dos constituintes minerais, descontinuidades e vazios.

Os fatores extrínsecos são a temperatura $(t)$, potencial hidrogênico $(\mathrm{pH})$, potencial de oxi-redução $(\mathrm{eH})$, quantidade de ägua (1) e forças biôticas (b). 
Verifica-se experimentalmente a variação das propriedades físi cas e mecânicas das rochas com alteração, particularmente as resistências à compressão, à abrasão Los Angeles, ao impacto Treton, ao esmagamento. Observa-se tambẻm, a variação do mödulo de elasticidade. Deve-se observar que muito embora essas variações se façam no sentido de uma diminuição das citadas propriedades, processos como limonitizações podem conduzir a um au mento nos valores das propriedades mecânicas.

\section{Testes de Durabilidade}

São métodos que se propõem a avaliar a mudança de resistência mecânica de rochas ao enfraquecimento e desintegração resultantes de ciclos de secagem-umidecimento.

0 procedimento nos testes usuais ê de imergir algumas amostras em ägua e observar quaisquer expansões ou desintegrações que possam ocorrer. Embora usados frequentemente, os resultados dos testes em questão são mui tas vezes de valor limitado e as tëcnicas precisam ser melhoradas.

0 termo durabilidade pode ser usado num contexto de engenharia, para traduzir a resistência ao enfraquecimento e desintegração das rochas no decorrer do tempo, isto ê, sua resistêncla ao intemperismo. Para cada um dos muitos agentes intempëricos, um diferente aspecto de durabilidade pode ser definido, como durabilidade ao congelamento, ã abrasão e ao umide cimento. Diferentes testes são necessärios para predizer os efeitos dos di versos agentes intempëricos. Um teste de durabilidade prediz a deterioração devida ã secagem e umidecimento climảticos.

A durabilidade à hidratação de uma rocha depende do seguinte:

a) Permeabilidade e porosidade, jä que estas controlam a entrada e a retenção dos fluidos nos poros da rocha e sua mobilidade no seu interior:

b) A ação dos fluidos que tenham penetrado na rocha. Eles podem agir por absorção resultando em mudanças na energia superficial, por dissolução de cimentos ou ruptura das ligações, podendo ainda originar forças de ruptura através de mecanismos de porompressōes.

A capacidade de uma rocha resist ir a forças de ruptura ditarä as condiçōes potenciais para que ocorram enfraquecimentos, entumescimento ou desintegração completa do material testado. 
Pelos motivos citados, um rocha que seja impermeävel, não reativa ou que tiver força intergranular elevada, ẽ usualmente durável.

Os efeitos da hidratação podem ser julgados pela observação descrição do material em teste, pelo acompanhamento das tensões de expansão ou pelo peneiramento das amostras afim de determinar a redução de tama nho como resultado do processo de hidrataçãot o ültimo método pode ser preferido desde que ocorram fragmentações apreciäveis e que a amostra seja grande e suficientemente representativa do material em estudo.

\section{Ensaios mecânicos}

\section{Resistência ao impacto Treton}

\section{Segue as especificações IPT $M-52$.}

Consiste o ensaio em submeter 20 fragmentos de arenito com as dimensões de $1 / 2^{14}$ a $3 / 4^{\prime \prime}(12,7$ a $19,05 \mathrm{~mm})$ lavados e secos em estufa às temperaturas de $100-110^{\circ} \mathrm{C}$, por 24 horas, a 10 impactos de um peso de $15912 \mathrm{~g}$, caindo de uma altura de $37,5 \mathrm{~cm}$, em queda livre, no aparelho Treton (Figura 2). Apös este procedimento, o material ë lavado em ägua corren te na peneira nümero $12(1,68 \mathrm{~mm})$, até que as suas superficies fiquem $1 \mathrm{i}$ vres de pó, sendo posteriormente secado na estufa, por 24 horas, às temperaturas de $100-110^{\circ} \mathrm{C}$, resfriado e pesado. Para cada granulometria são fei tas 3 determinaçöes. A resistência ao Impacto Treton ë a relação percen tual entre as diferenças de peso inicial $\left(P_{i}\right)$ e final $\left(P_{f}\right)$ pelo peso inicial, ou seja:

$$
T=\frac{P_{i}-P_{f}}{P_{i}} \times 100
$$

E considerada a média dos três resultados.

Algumas das amostras ensaiadas foram submetidas a processos art ficiais de intemperização com o extrator Sohlet.

0 extrator Sohlet consiste essencialmente de um sistema que propicia a percolação de ägua atravës de fragmentos de rocha contidas num vidro (Figura 3).

Säo simuladas aí as condiçôes das zonas atmosfërica, de flutua ção do nivel freảtico e de saturação permanente, originando condições de 

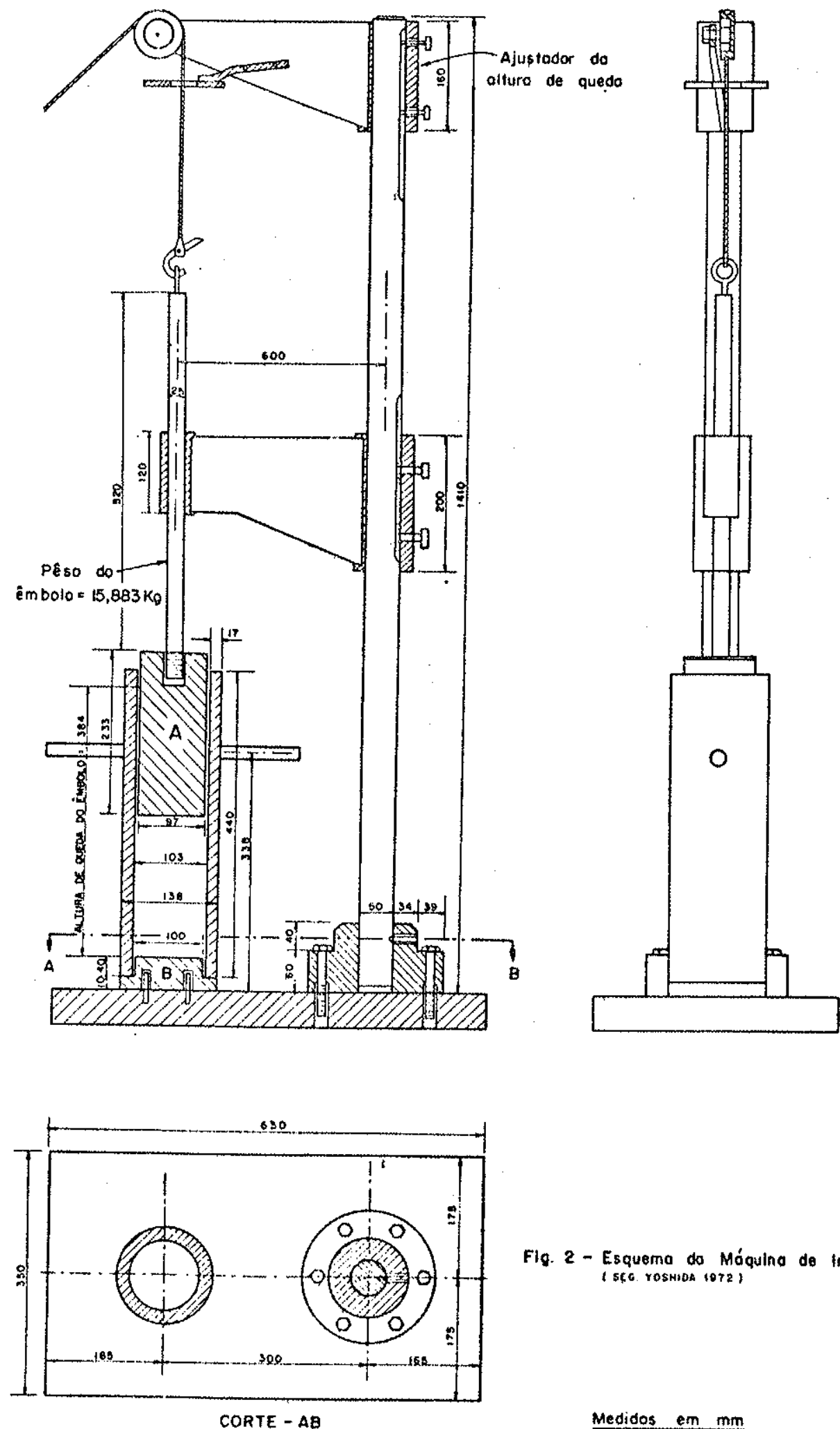

Fig. 2 - Esquerna do Máquina de impacto "Treton" (stG. YOSHIDA (072)

Medidos em $\mathrm{mm}$ 
FRAGMENTOS DE ROCHA

ZONA ATMOSFÉRICA

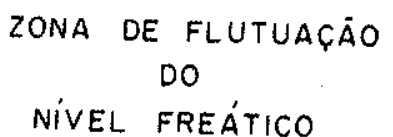

NIVEL FREÁTICO

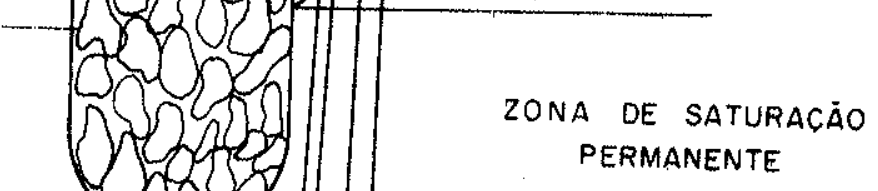

FIG. 3 - ESQUEMA DE UM EXTRATOR SOXHLET (SEG. FARJALLAT, 1972) 
alterabilidade do material e possibilitando o controle dos parâmetros experimentais como natureza das soluções de lavagem, incidência do líquido sobre a amostra, nivel hidrostätico, temperatura, etc.

\section{Resistência à Abrasão Los Ange les}

Este ensaio que segue as diretrizes das especificações ASTMC131-55, consiste fundamentalmente em se determinar a perda de peso de uma certa quantidade de fragmentos de rocha quando desgastadas por uma carga abrasiva que gira à velocidade de 30 a $33 \mathrm{rpm}$ juntamente com as amostras, na mäquina Los Angeles (Figura 4). No caso, a carga abrasiva foi represen tada por 12 bolas de aço pesando $5 \mathrm{~kg}$. Apös o ensaio, as amostras são lavá das em ägua corrente, sobre a peneira 12 (ASTM), em seguida levado à estufa à temperatura de $100-110^{\circ} \mathrm{C}$, por 24 horas, resfriado em ambiente seco e pesado. A resistência à abrasão Los Angeles é calculada como a relação dos pesos inicial e final, pelo peso inicial, ou

$$
A=\frac{P_{i}-P_{f}}{P_{i}}, \text { sendo }
$$

$P_{i}=$ Peso inicial, em gramas, passando na peneira 3".

$P_{f}=$ Peso final, em gramas, retido na peneira $11 / 2^{\prime \prime}$.

$A=$ Resistência à abrasão Los Angeles, em percentagem.

\section{Ensalos de compressão simples axial e deformabilidade}

Este método de ensaio obedece às especificações IPT M-50.

Consiste em submeter corpos de prova cübicos ou cilindricos, estes com relação altura/diâmetro compreendida entre 2 a 4 vezes, a esforços
de compressão axial.

0 equipamento utilizado e a montagem do ensaio são apresentados esquematicamente na Figura 5.

Os corpos de prova são colocados na prensa entre duas almofadas de madeira visando una melhor distribuição das cargas aplicadas.

0s ensaios são realizados com corpos de prova secos em estufa 24 horas ou saturados a partir de imersão em ãgua por 48 horas. São determina 


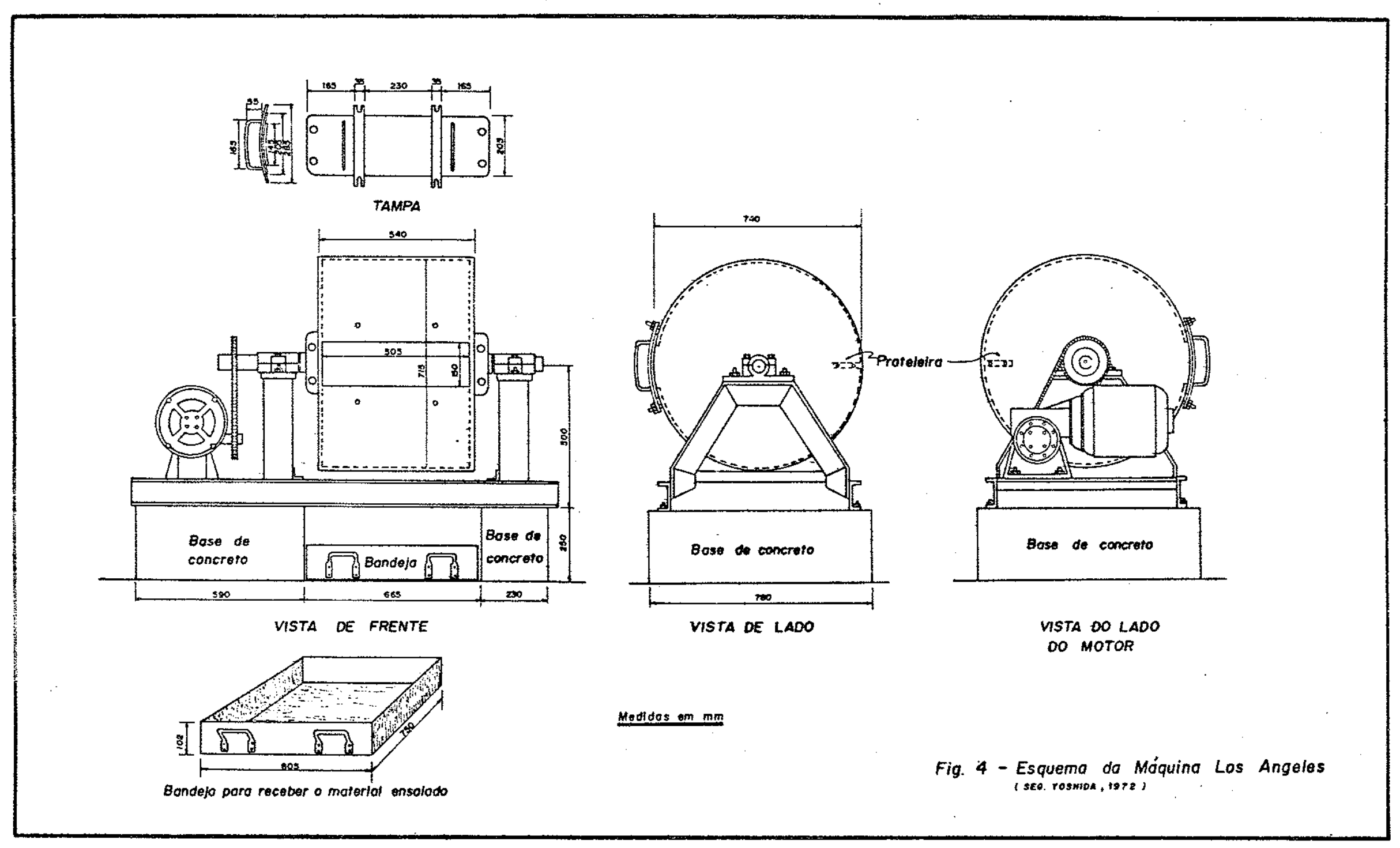




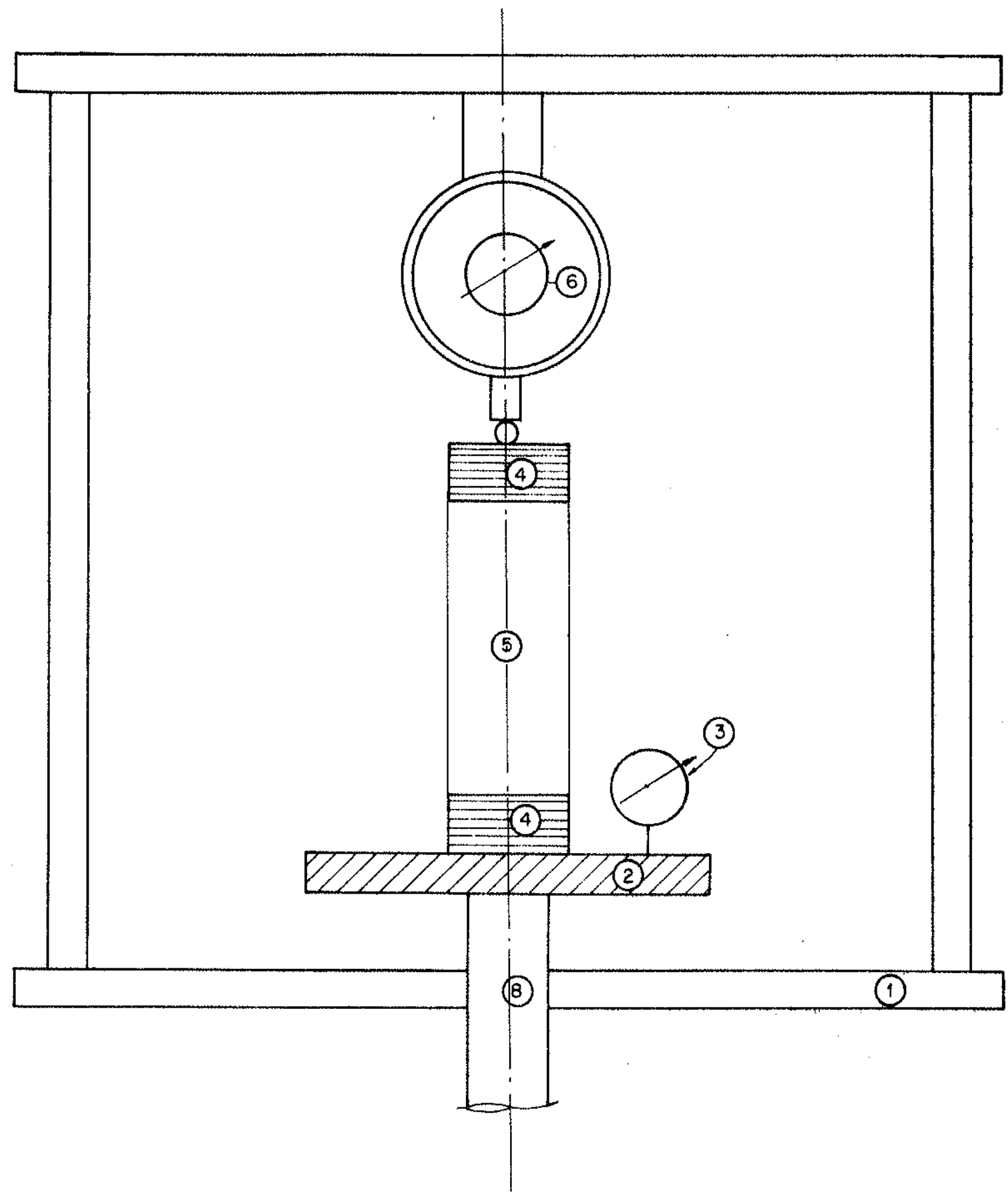

1 - Estrutura da prensa

2 - Prato da prensa

3 - Extensômetro paro medir deformaçöes do proto

4 - Almofadas de madeira

5 - Corpo de prova

6 - Extensômetro para medir deformaçōes no dinamômetro

7 - Dinamômetro

8 - Pistāo que transmite a carga

FIG. 5 - CORTE ESQUEMÁTICO DE UMA MONTAGEM PARA ENSAIO DE COMPRESSĀO SIMPLES AXIAL 
dos os parâmetros físicos, prêviamente aos ensaios propriamente ditos.

Realizado o ensaio de compressão, as tensões de ruptura $\left(\sigma_{c}\right)$ são calculadas pelo quociente da carga de ruptura $\left(\gamma_{\text {rup }}\right)$ pela ärea mëdia da seção transversal do corpo de prova $(A)$, ou seja

$$
\sigma c=\frac{\gamma_{\text {rup }}}{A}
$$

São medidas as deformações correspondentes durante a compressão, que possibilitam os câlculos do Mödulo de Deformabilidade do material ensaiado.

\section{Resistência ao cisalhamento - compressäo triaxial}

Os ensaios de resistência ao clsalhamento por compressão triam xial ë realizado normalmente, para solos e materiais brandos, com um equi pamento como o esquematizado na Figura 6 ,

0 processo consta fundamentalmente em submeter-se um corpo de prova cilindrico geralmente com $\phi$ de $2,5 \mathrm{~cm}$ e altura de $10 \mathrm{~cm}$, a um estado duplo de tensões, atë a ruptura.

Este estado duplo de tensões configura-se nas tensões normais $\left(\sigma_{1}\right)$ e nas confinantes $\left(\sigma_{3}\right)$.

Como o pröprio nome do ensaio o diz, o estado de tensões deveria ser triplo, com as tensões $\sigma_{1}, \sigma_{2}$ e $\sigma_{3}$, porëm dado que uma montagem para tal ensalo redunda em sërias complicações, e por outro lado, sua interpretação muito mais dificil, consagroumse tornar as tensões $\sigma_{2}$ iguais a $\sigma_{3}$, donde resultou um ensaio com estado duplo de tensões, embora o nome do ensaio continue sendo "trlaxial".

0 corpo de prova, colocado na câmara e envolvido por uma membrana de borracha, conforme o esquema, ë submetido inicialmente a um estado de tensões equilibrado, ou seja as tensões normas säo iguais às confinentes. Posteriormente, aumenta-se a diferença $\left(\sigma_{j}-\sigma_{\dot{3}}\right)$ atè o rompimento do corpo de prova. Outros corpos de prova, idênticos ao primeiro, são submet dos a diferentes pares de tensões $n_{1}, \sigma_{3}$. Conforme seja conveniente, medem - se as pressões neutras (devidas à ägua intersticial no corpo de prova), que modificarn os valores das resistências ao cisalhamento, obtidas.

As tensões normais $\left(\sigma_{1}\right)$ são aplicadas ao corpo de prova por um êmbolo vertical acoplado a um sistema mecânico que transmite a força en- 


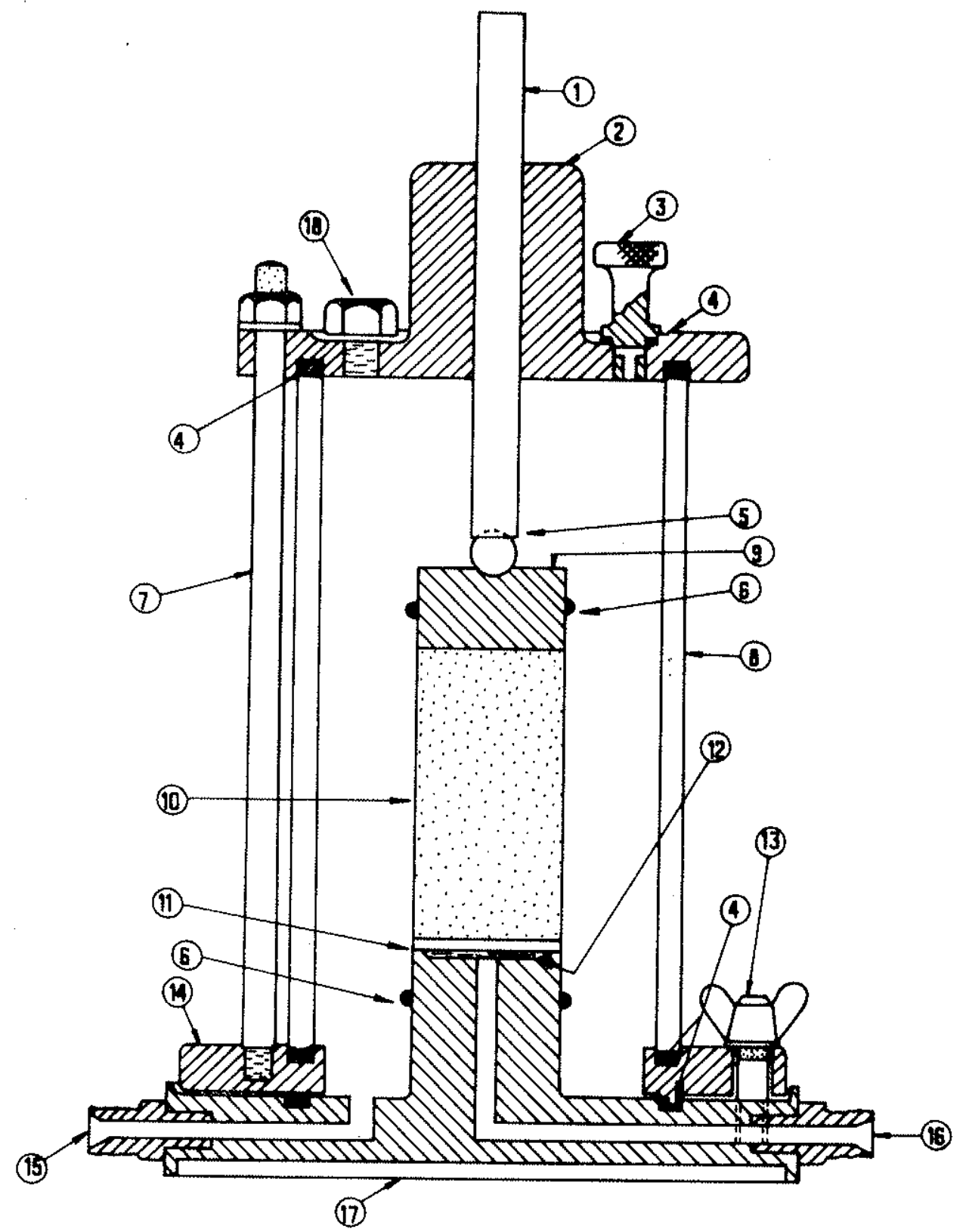

1 - Pistão de aplicação da força normal

2 - Cabeça de camöra triaxial

3 - Válvula de saída de ar

4 - Arruelas de berracha

5- Esfera - pistāo com àngulo interno de $120^{\circ}$

6 - Arruelas de borracha, para prender a membrana de borracha

7 - Barra para prender

8 - Cilindro de Lucite

9 - Cabega de Lucite, cotocada em cima do corpo de prova

10 - Corpo de prova envolto por membrana de borracha

11 - Pedra porosa

12 - Chapa motálica

13 - Parafuso - porca para prender o anel 14 b bose

14 - Colar do latäo

15 - Entrada - saida d' agua a cõmara

16 - Tubulaçäo pora dronagem ou medir pressäo neutro

17 - Bose da camära triaxial

10- Entrada de água

FIG. 6 - ESQUEMA dA CÁMARA PARA ENSAIOS TRIAXIAIS EM SOLOS. 
quanto que as confinantes $\left(\sigma_{3}\right)$ são aplicadas por um líquido, como por exem plo, a ägua.

Com os diversos pares de valores de $\sigma_{1}, \sigma_{3}$ obtidos, traçam-se, num gräfico $($. (resistência ao cisalhamento) nas ordenadas $x \quad \sigma$ (tensões normais e confinantes) nas abcissas. Obtem-se então, os circulos de ruptura (círculos de Mohr) e a envoltôria de resistência (envoltöria de Mohr- Coulomb), processo mais comumente empregado para o câlculo da resistência ao cisalhamento sob solicitação triaxial.

A envol tốria de resistência, obedece à equação

$$
\widetilde{\sigma}=c+\sigma+g \phi, \quad \text { sendo }
$$

$\zeta=$ tensões cisalhantes, durante o ensaio

$\sigma=$ tensões normais durante o ensaio

c = coesão do material - quando diferente de zero, vem a ser o valor numérico do intercepto da envoltöria com o eixo dos $\tau$

$\phi=$ ângulo de atrito interno do material - igual ao ângulo entre a envoltöria com a horizontal.

As tensões rup e orup no instante da ruptura não podem ser medi das diretamente no plano de ruptura. No entanto podem ser obtidas seja no

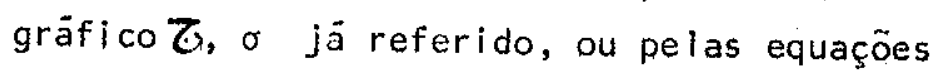

$$
\text { orup }=\frac{1}{2}\left(\sigma_{1}+\sigma_{3}\right)+\frac{1}{2} \cdot\left(\sigma_{1}-\sigma_{3}\right) \cos 2 \alpha
$$

e

$\sigma_{\text {rup }}=\frac{1}{2}\left(\sigma_{1}-\sigma_{3}\right) \operatorname{sen} 2 \alpha$

onde:

$\sigma_{\text {rup }}=$ Tensão normal no momento da ruptura

$\tau_{\text {rup }}=$ Tensão cisalhante no momento da ruptura

$\alpha$ a àngulo formado pelo plano de ruptura com a horizontal

Demonstramse, a partir do círculo de Mohr que

$$
\alpha=45+\frac{\phi}{2} \text {, }
$$


relação de grande importância nas interpretações analíticas do fenômeno de rupturas por solicitação triaxial.

\section{Permeabilidade}

A permissividade de um meio qualquer à passagem de um fluido é função das propriedades físicas do meio poroso e do fluido em questão. De acordo com a lei de Darcy

$$
Q=A \cdot K \cdot i \text {, onde }
$$

$Q=$ quantidade de ägua (vazão)

$\mathbf{i}=$ gradiente hidräulico

$K=$ coeficiente de permeabilidade

$A=$ ärea da seção transversal do corpo de prova.

Bernaix faz a distinção entre rocha vacuolar, na qual os inters tícios têm geralmente a forma esférica, e as fraturadas, onde as descontinuidades possuem configuração linear. Nas rochas do 19 tipo, geralmente a permeabilidade varia muito pouco com as variações dos campos de tensões am bientes, mas nas do $2 \%$ tipo não apenas a acentuada anisotropia, como tambëm sua condutividade hidräulica poderão ser altamente influenciadas pelas variações do campo de tensões, devido à variação da resistência ao fluxo apresentada pelas formações configuradas pelo fechamento ou abertura das descontinuidades como resposta às mudanças do campo de tensões ao redor das mesmas.

Para rochas cristalinas, de multo baixa permeabilidade, adota-se hoje em dia o emprego de um gảs como fluido de percolação. Justifica-se ain da este processo, pelo fato de que no ensaio com ägua as rochas são rapida mente afetadas pela ação deste líquido, o que pode modificar bastante a rede de descontinuidades matriciais e portanto, a permeabilidade. Por tais razões, utiliza-se com bons resultados, o ar seco.

Para os arenitos Caiuâ, as determinações da permeabilidade foram feitas pelo método de permeabilidade à ägua.

0 equipamento utilizado foi um permeâmetro de carga variâvel (FI gura 7). Inicialmente, foi reallzada a saturação dos corpos de prova com ägua desprovida de ar. A saturação foi efetuada por contra pressão, ou seja, através de um fluxo de ägua de baixo para cima. Após esta operação, 


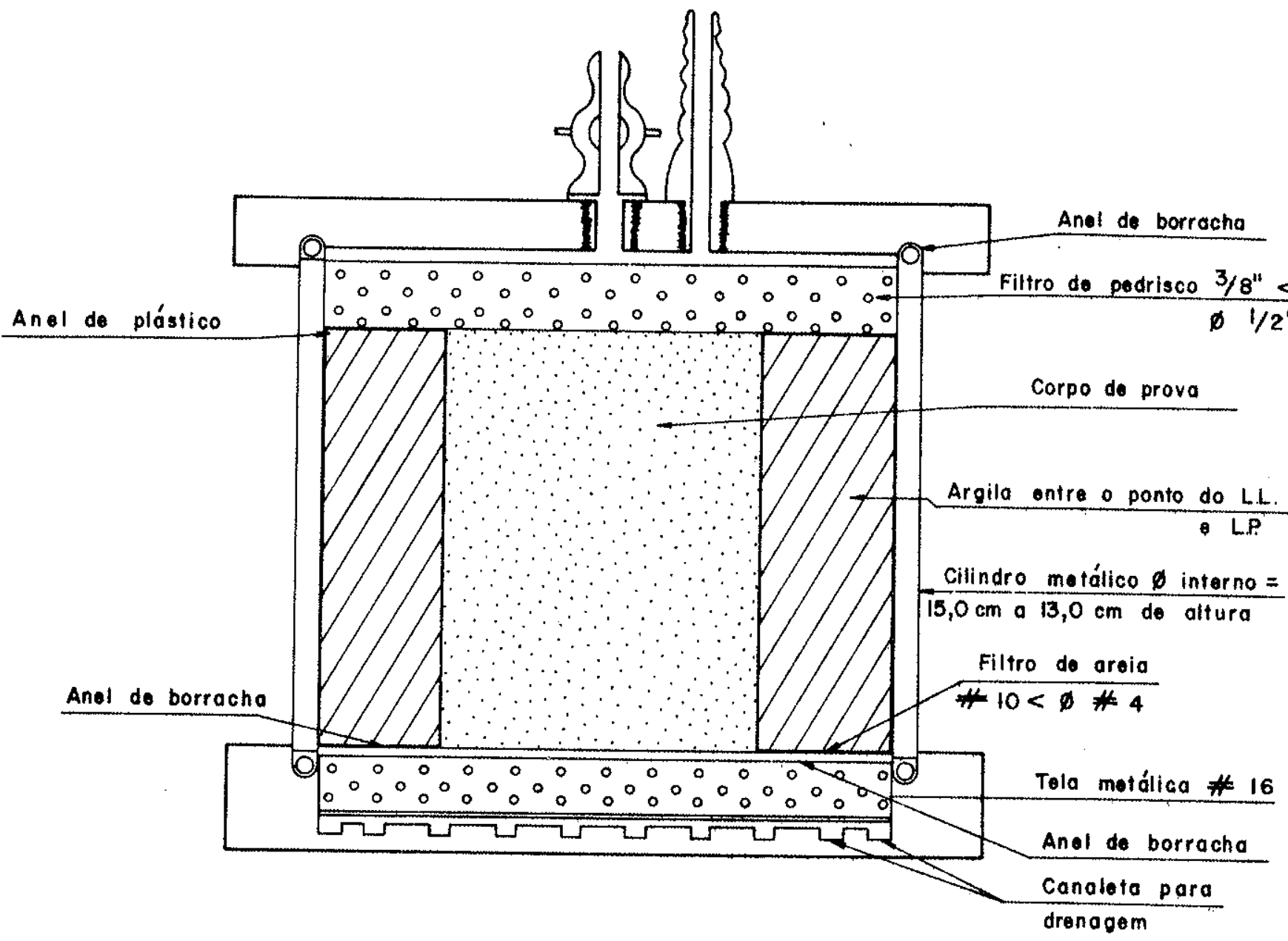

FIG. 7 - CORTE ESQUEMÁTICO DE UM PERMEÃMETRO 
configurada pelo vazamento da água no topo do permeâmetro, o fluxo foi invertido, passando-se então a fazer leituras na bureta graduada.

A expressão usada para o cảlculo de $K$ foi

$k=\frac{2,3 a \cdot L}{A \cdot \Delta t} \quad \log \frac{h_{i}}{h_{f}}$, sendo

$k=$ coeficiente de permeabilidade para a temperatura de $20^{\circ} \mathrm{C}$

$a=$ ärea da seção da bureta

$L=$ altura do corpo de prova

$A=$ ärea do corpo de prova

$\Delta t=$ tempo decorrido entre duas leituras

$h_{i}=$ leitura inicial

$h_{f}=$ leitura final 
CAPTTULO IV

APRESENTAÇÃO E INTERPRETAÇÃO DOS DADOS

Tratar-se-ä a seguir, da apresentação dos dados referentes aos testes, estudos e determinaçōes efetuados, segundo as metodologias explica das anteriormente.

A proposição de se adotar uma postura crítica quanto aos resulta dos, ë evidenciada sempre que possivel, pois trata-se de uma das premissas mais significativas a que este trabalho se propõe.

\section{Questões relacionadas ã Mineralogia e Petrografia}

As amostras ensaiadas pertenciam ao Conjunto 4 (sondagens SR-23-A, SR-26-A e amostra nümero 44; e do Conjunto 1, amostras nümeros 1, 2, 3 e 4 .

Os exames macroscöpicos e das seçōes delgadas (fotos nümeros 14 a 27) permitiram concluir que os arenitos Caiuä em questão apresentam uma percentagem extremamente elevada de material detritico sllicatado, sendo o feldspato representado pelo microclínio mas tambëm algum plagiocläsio. Os acessórios mais comuns são a biotita e muscovita, e outros opacos. Os grãos de quartzo apresentam-se geralmente parcialmente corroídos e com evi dëncias de re-crescimento secundärio. Os hidröxidos de ferro aparecem revestindo os grânulos de quartzo e algumas vezes são substituídos pela calcita. Os hidröxidos de ferro naturalmente evidenciam ambiente oxidante du rante a deposição.

Nas 11 seções delgadas confeccionadas com material do conjunto 1 de amostras, verifica-se que as percentagens de quartzo comum, ondulante e policristalino variaram de 82 a $96 \%$, enquanto que o feldspato potäsio e plagiocläsio ocorreram no intervalo entre 3 e $18 \%$. Segundo Turner e Gilbert (1970), os "arenitos feldspâticos" ou "wacke feldspatico" são aren! 


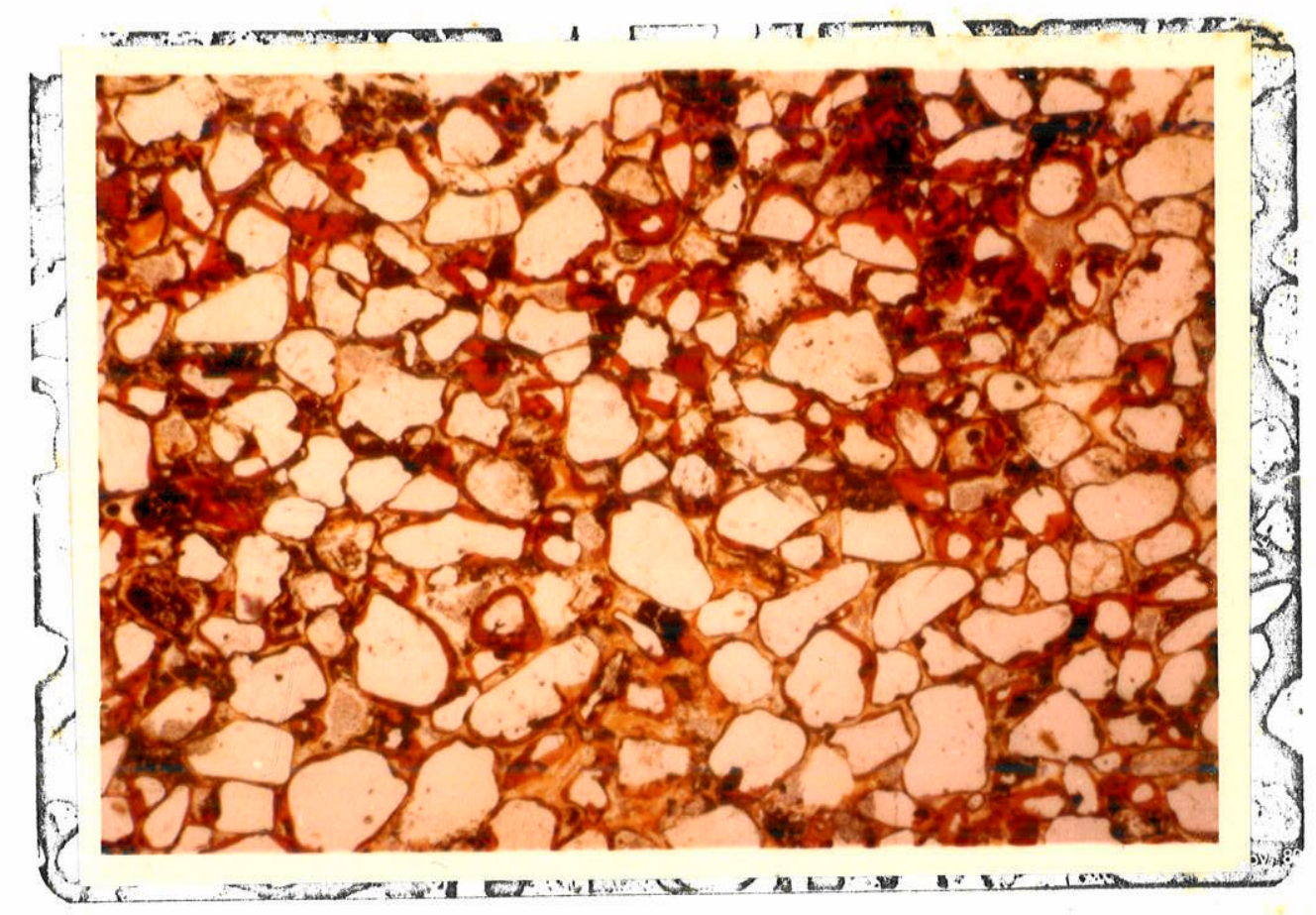

FOTO NN 14

LAMMINA No $1\left\{\begin{array}{l}\text { Aumento de } 35 x \\ \text { Nicöis paralelos }\end{array}\right.$

SONDAGEM NO SR-15, AMOSTRA NO 1

PROFUNDIDADE (m) - 12,30

ALTITUDE (m) $\quad-243,71$

Arenito com textura clästica, grãos subangulosos a arredondados equi dimensionais e prismäticos principalmente de quartzo e secundariamente de feldspato potâssico. Seleção de boa a regular. Estägio de maturidade textural, maturo-submaturo. Rara matriz argilosa, película de cimento limonitico envolve os grãos de quartzo. Alguns desses com recrescimento secundärio. 


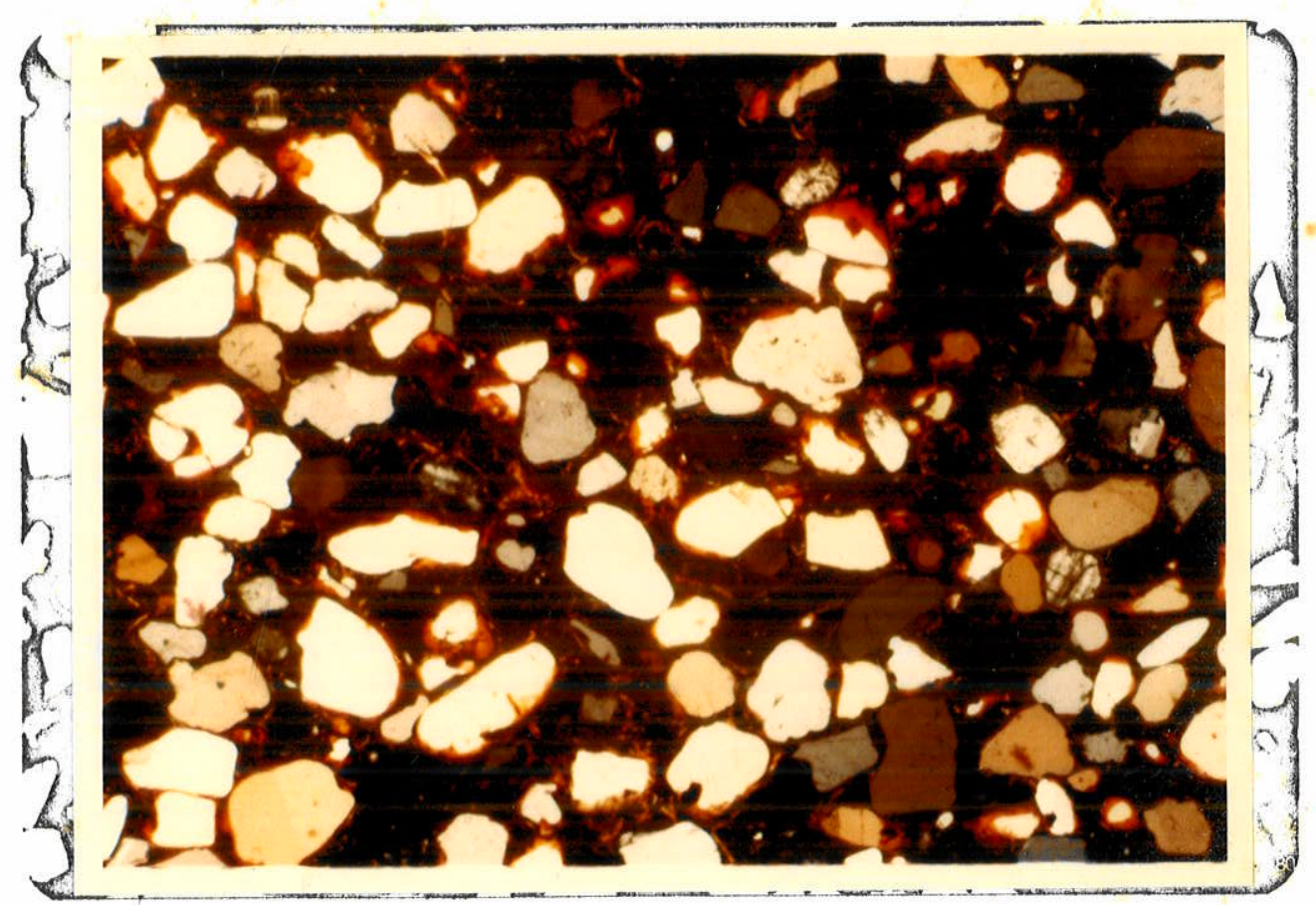

FOTO N: 15

LAMINA No $2\left\{\begin{array}{l}\text { Aumento de } 35 x \\ \text { Nicöis cruzados }\end{array}\right.$

SONDAGEM N: SR-15, AMOSTRA NN: 1

PROFUNDIDADE (m) - 12,30

ALTITUDE (m) $\quad-243,21$

DESCRIÇÃO: A mesma da FOTO No 15, LẢMINA No 1 


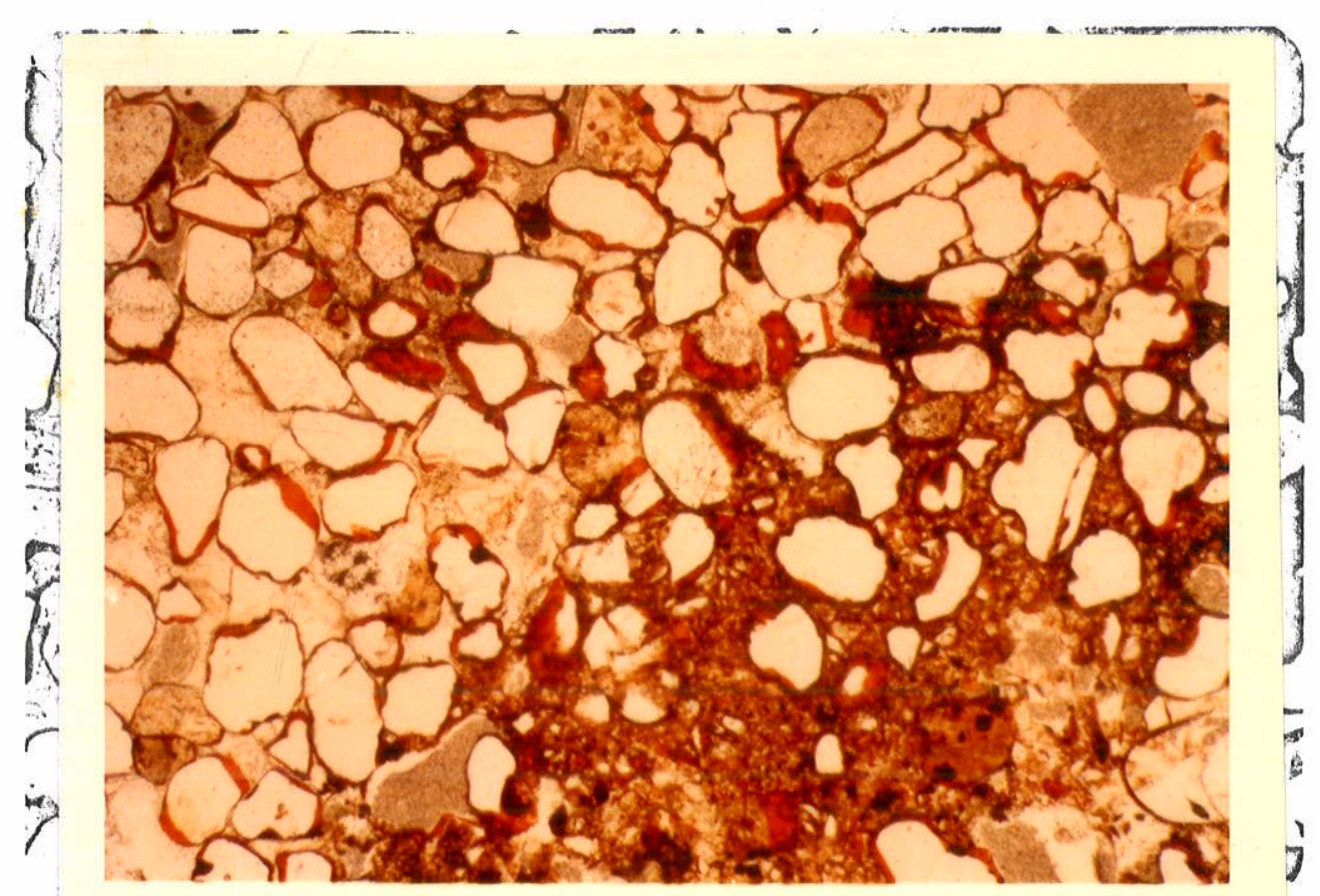

FOTO N ㅇ. 16

LAMINA N: $3\left\{\begin{array}{l}\text { Aumento de } 35 x \\ \text { Nicóis paralelos }\end{array}\right.$

SONDAGEM NO SR-3, AMOSTRA N $: 8$

PROFUNDIDADE (m) - 32,60

ALTITUDE $(m)-208,43$

Arenito de textura clästica, gräos subangulosos a arredondados equidimensionais de quartzo e feldspato. Seleção de boa a regular, estágio de maturidade textural de submaturo a maturo. Teor de argila < $50 \%$. Matriz siltosa aparece na parte inferior direita da foto. Grãos de quartzo com películas de limonita envolvendo-os. Feldspato princi palmente intemperizados, cimento limonítico e carbonätico. 


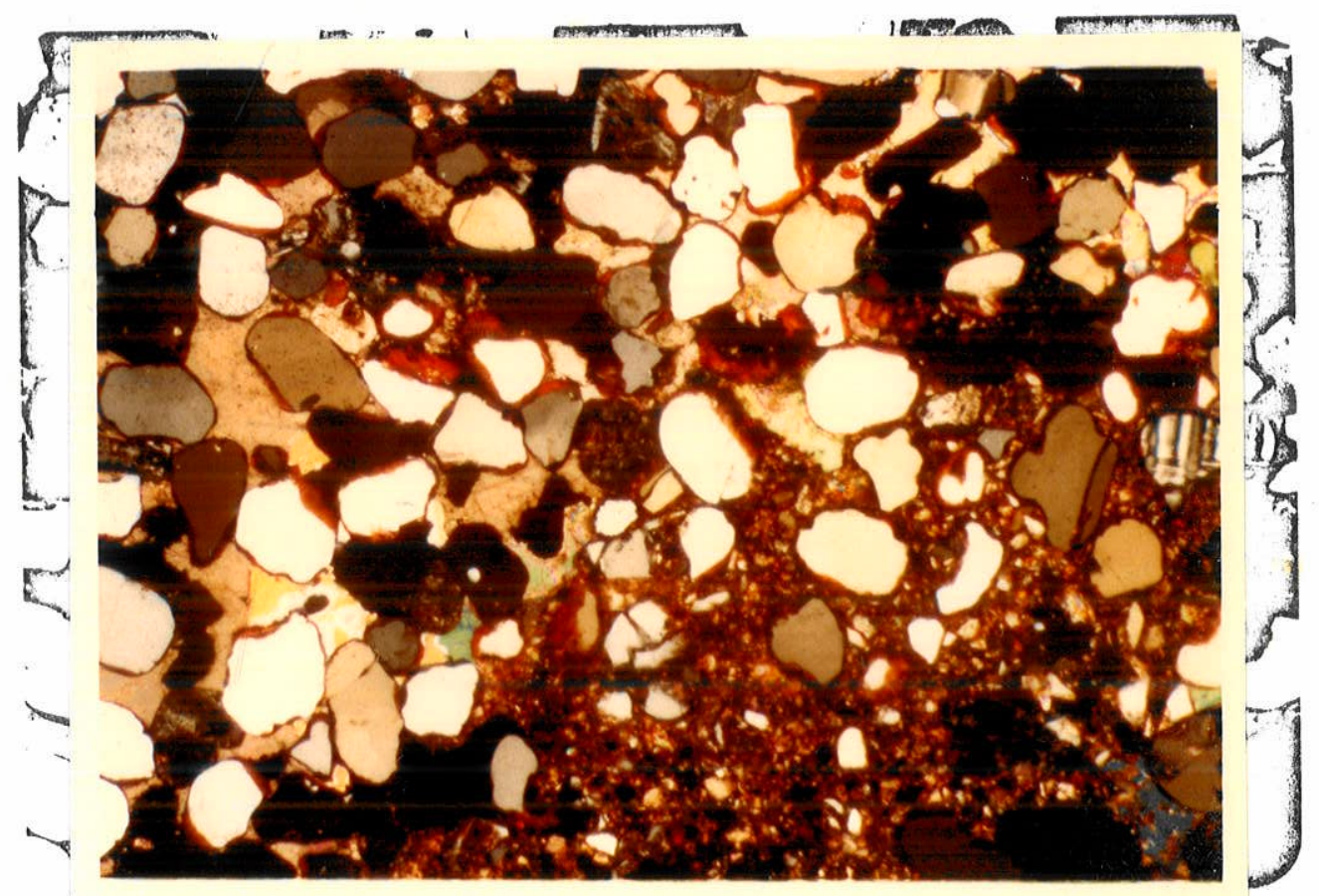

FOTO № 17

LAMINA NO 4

$$
\left\{\begin{array}{l}
\text { Aumento de } 35 x \\
\text { Nicöis cruzados }
\end{array}\right.
$$

SONDAGEM NN SR-3, AMOSTRA NN 8

PROFUNDIDADE $(\mathrm{m})-32,60$

ALTITUDE (m) - 208,43

DESCRIÇÃO: A mesma da FOTO No 16, LÂMINA № 3 


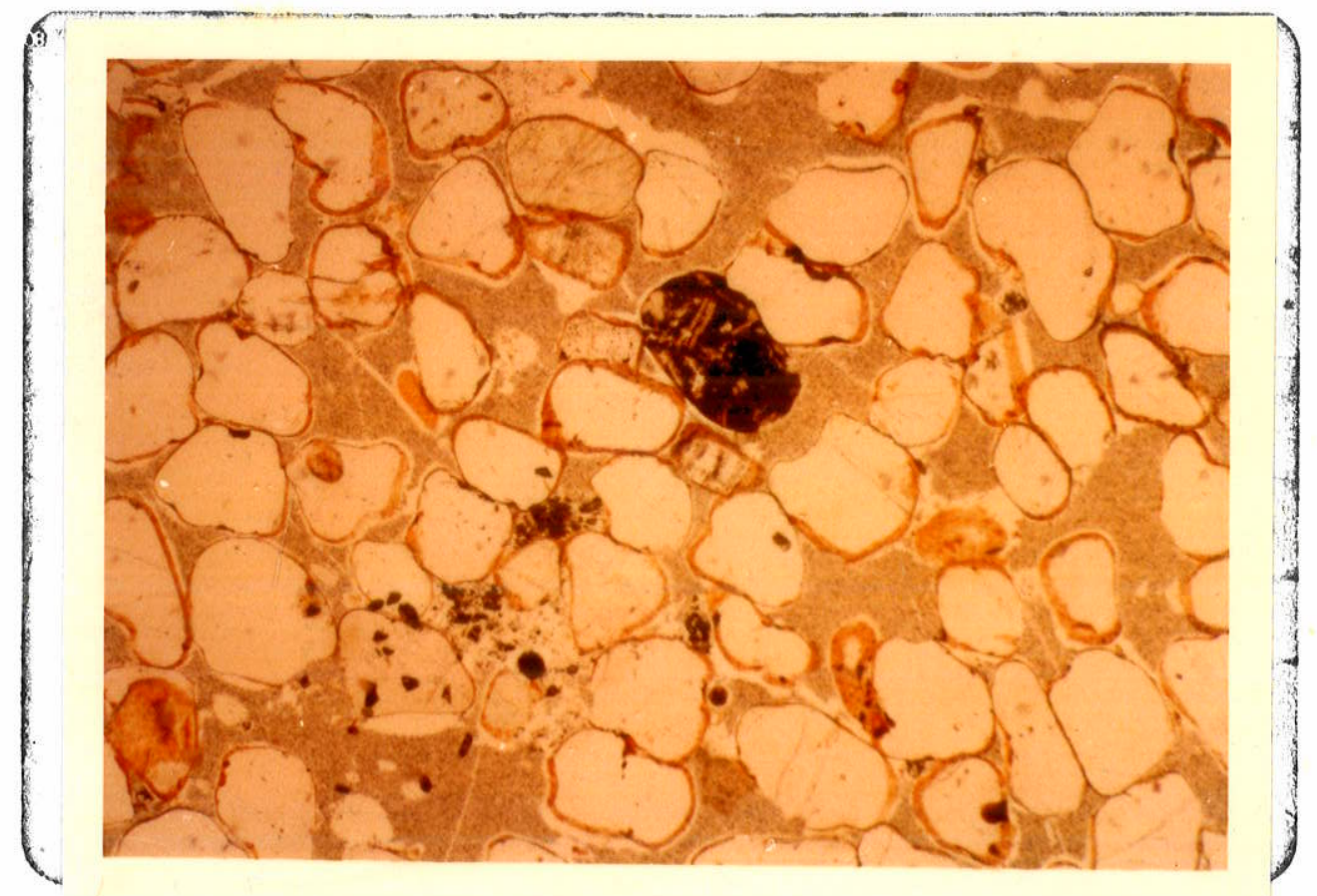

FOTO N. 18

LAMMINA No $5\left\{\begin{array}{l}\text { Aumento de } 35 x \\ \text { Nicỏis paralelos }\end{array}\right.$

AMOSTRA № 9

Arenito com textura clâstica, grãos subarredondados a arredondados de quartzo e feldspato. Boa seleção. Estägio de maturidade textural de submaturo a maturo. Teor de argila $<5 \%$. Cimento limonitico. Quartzo parcialmente corroído, com recrescimento secundärio e película de limonita. 


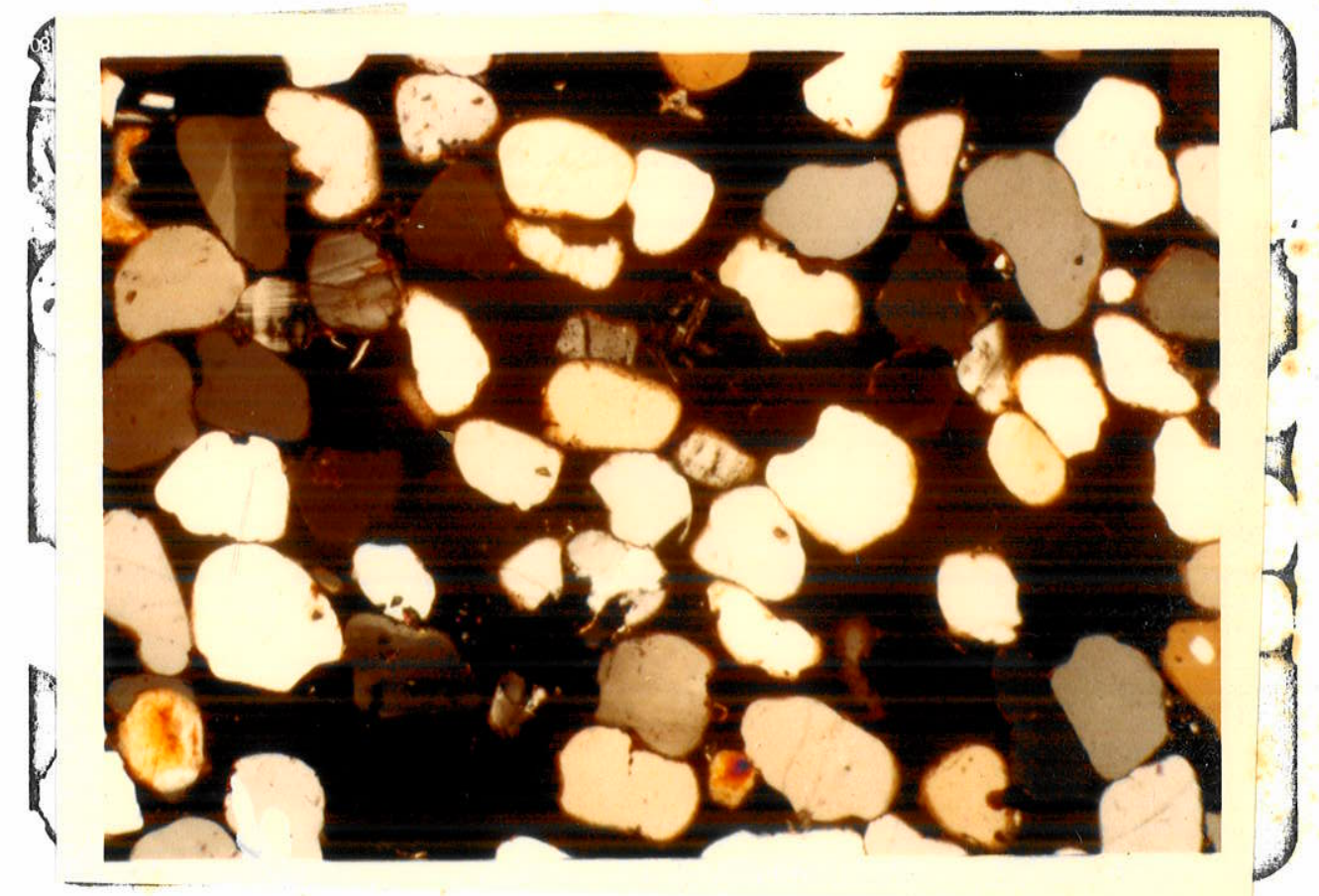

FOTO N. 19

LAMINA N: $6\left\{\begin{array}{l}\text { Aumento de } 35 x \\ \text { Nicöis cruzados }\end{array}\right.$

AMOSTRA NO 9

DESCRIÇÃO: A mesma da FOTO No. 18, LÂMINA No 5 


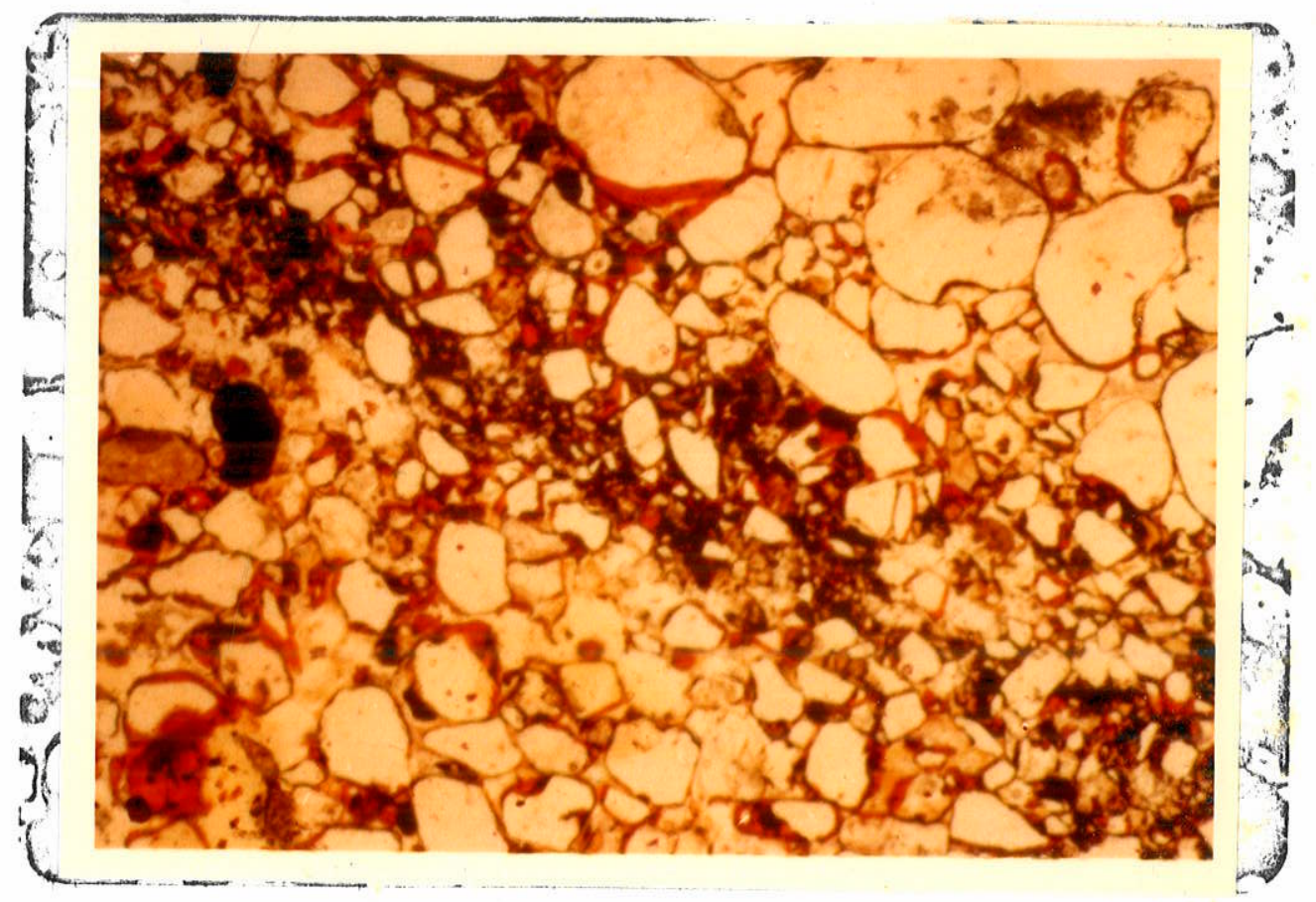

FOTO N: 20

LAMINA No $7\left\{\begin{array}{l}\text { Aumento de } 35 x \\ \text { Nicöis paralelos }\end{array}\right.$

AMOSTRA N $: 10$

Arenito com textura clästica, grãos subarredondados, arredondados, prismáticos e equidimensionais de quartzo e feldspato. Quartzo com peliculas de limonita, parcialmente corroído. Feldspato ligeiramen te intemperizado. Matriz siltica cimento limonítico. Teor de argila $<5 \%$. Seleção regular; estảgio de maturidade textural, submatu ro. Nota-se estratificação, atravessando a foto diagonalmente, de baixo para cima e da direita para a esquerda. 


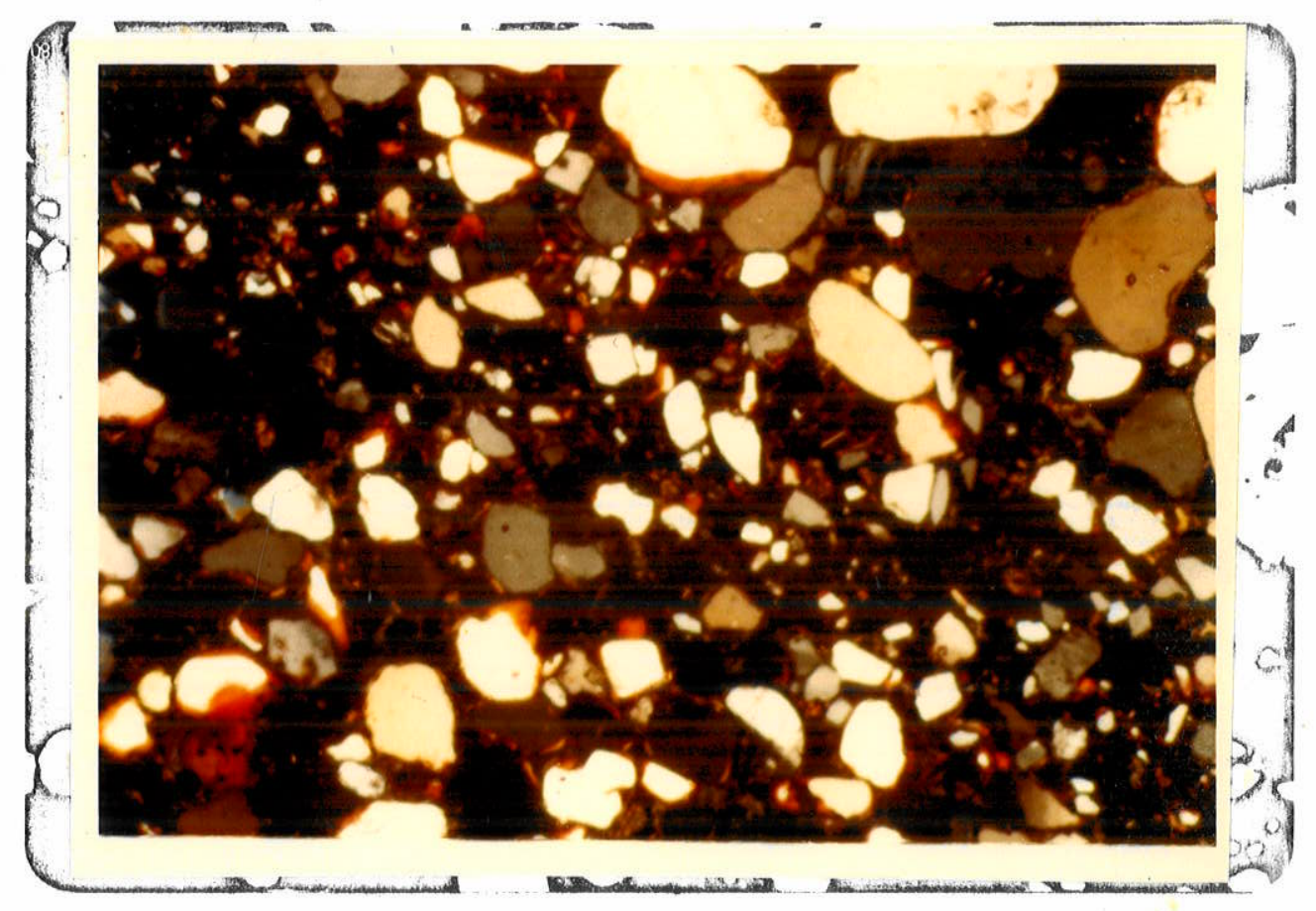

FOTO NN 21

LÂMINA No $8\left\{\begin{array}{l}\text { Aumento de } 35 \text { vezes } \\ \text { Nicöis cruzados }\end{array}\right.$

AMOSTRA N: 10

DESCRIÇÃO: A mesma de FOTO N: 20, LAMINA N: 7. 


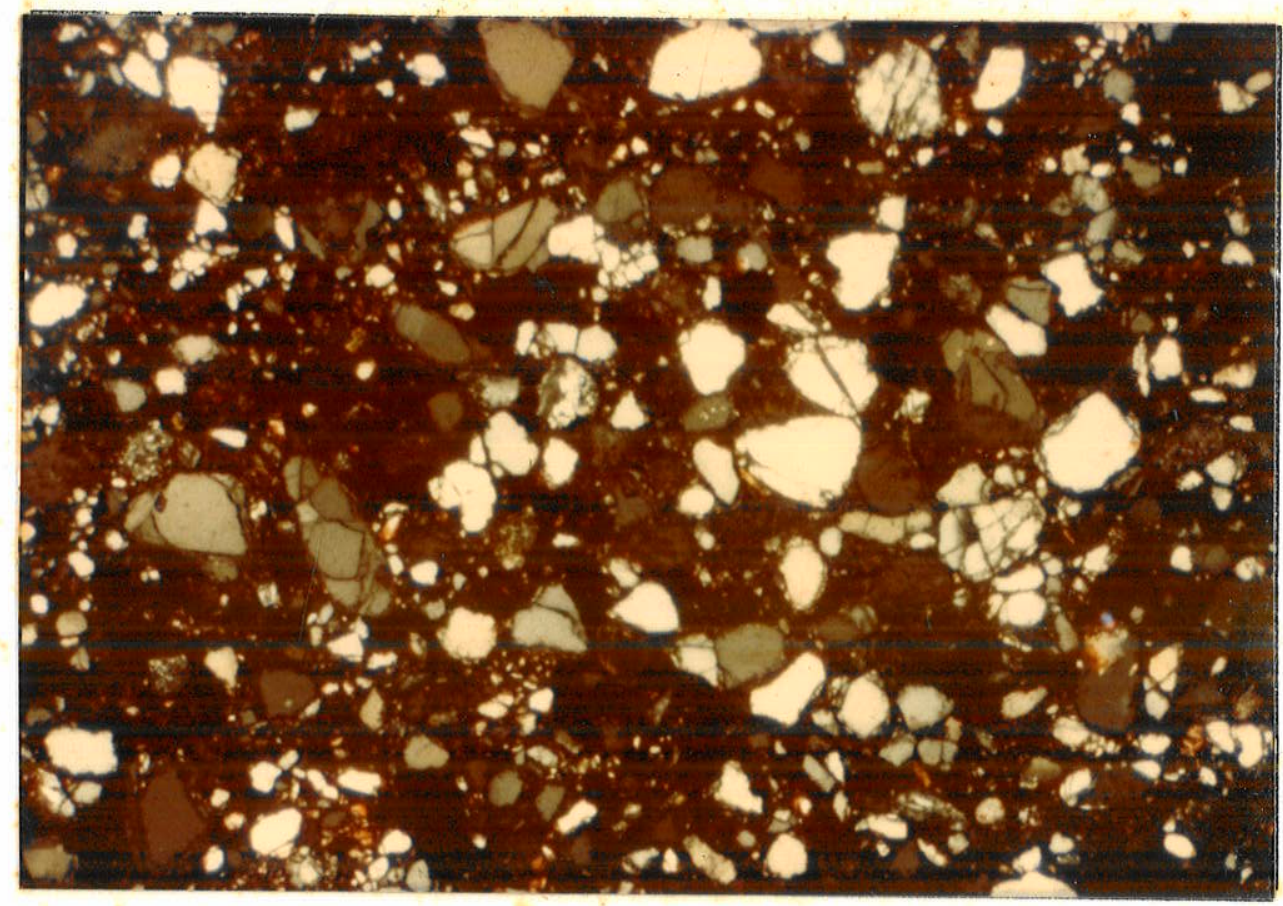

FOTO N. 22

LAMINA N: $9\left\{\begin{array}{l}\text { Aumento de } 35 x \\ \text { Nicöis cruzados }\end{array}\right.$

SONDAGEM N: SR-23-A - ALTITUDE (m) - 257,78 - AMOSTRA No 39

PROFUNDIDADE (m) - Entre 17,36 e 17,44.

ALTITUDE (m) - 241,42

Arenito com estrutura compacta, textura clástica. Granulometria varian do de 0,05 a 0,3 mm. Grânulos sub angulosos e sub arredondados, equidi mensionais e prismäticos de quartzo, microclinio, e outros minerais acessörios como calcedônia, epídoto (?), zircão, biotita, anfibölio, ci mentados por argilo-mineral e hidröxido de ferro. Ocorrem isoladamente lâminas com concentrações de cimento argilo-ferruginoso envolvendo os grânulos menores. A anălise feita por difratometria de raios-X da fração argilosa, revelou que o argilo mineral presente é dos grupos das montmorillonitas e das caulinitas. 


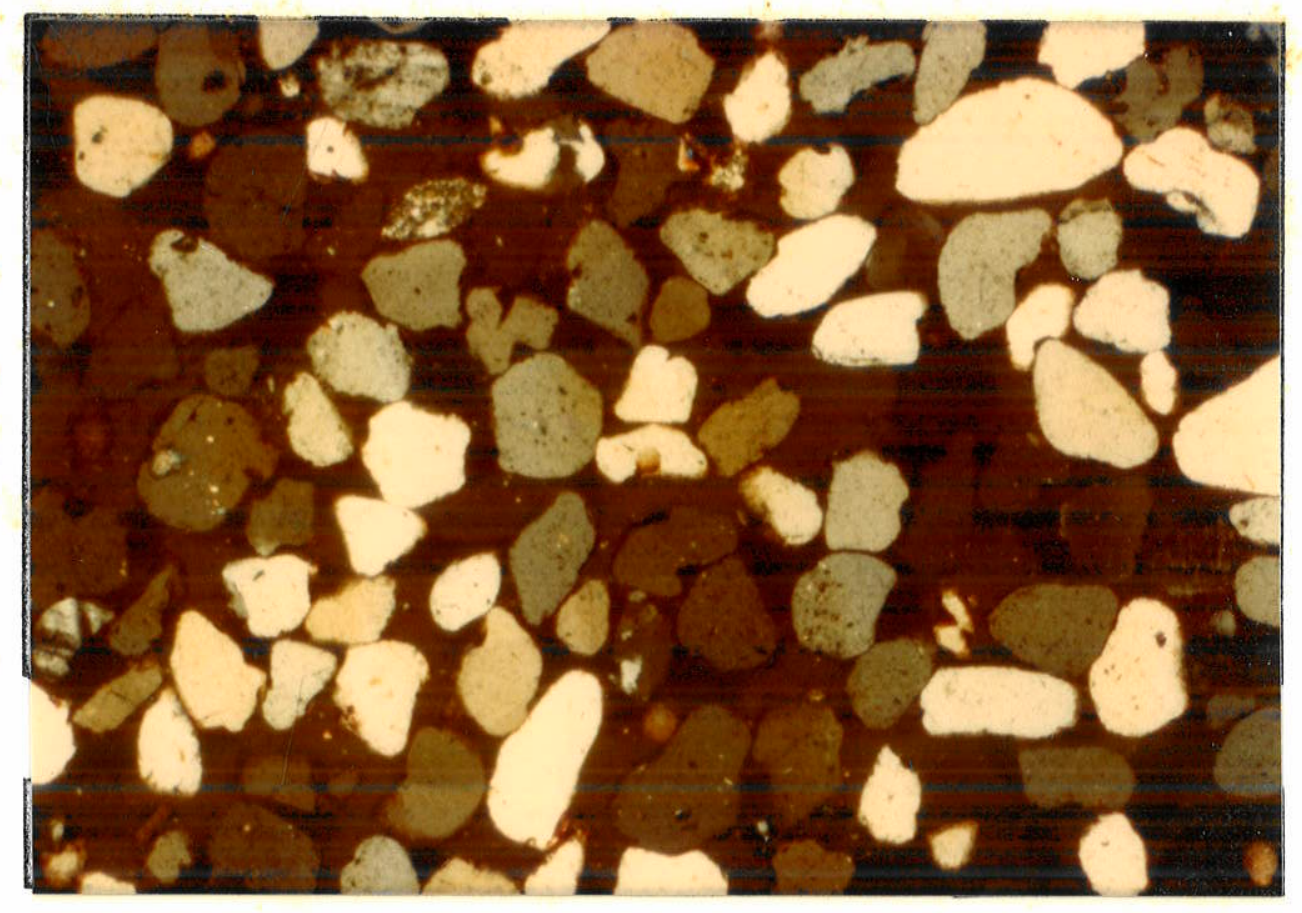

FOTO Nㅇ 23

LÂMINA No $10\left\{\begin{array}{l}\text { Aumento de } 35 x \\ \text { Nicōis cruzados }\end{array}\right.$

SONDAGEM NO SR-23-A - AMOSTRA NO 40

PROFUNDIDADE (m) - Entre 21,92 e 22,05

ALTITUDE (m) - 235,86

Arenito com estrutura compacta. Textura clästica. Granulometria variando entre areia mëdia a fina, com grânulos de diâmetro em torno de $0,3 \mathrm{~mm}$. Grãos sub arredondados e arredondados, equidimensionais e prismäticos de quartzo e feldspato (microclínio). Outros minerais acessörios: calcedônia, opacos, anfibölio e biotita. Cimento constituido por argilo-mineral e hidröxidos de ferro. 0s minerais argilosos existentes, revelados pela difratometria de raios-x, são dos grupos das montmorillonitas e das caulinitas. 


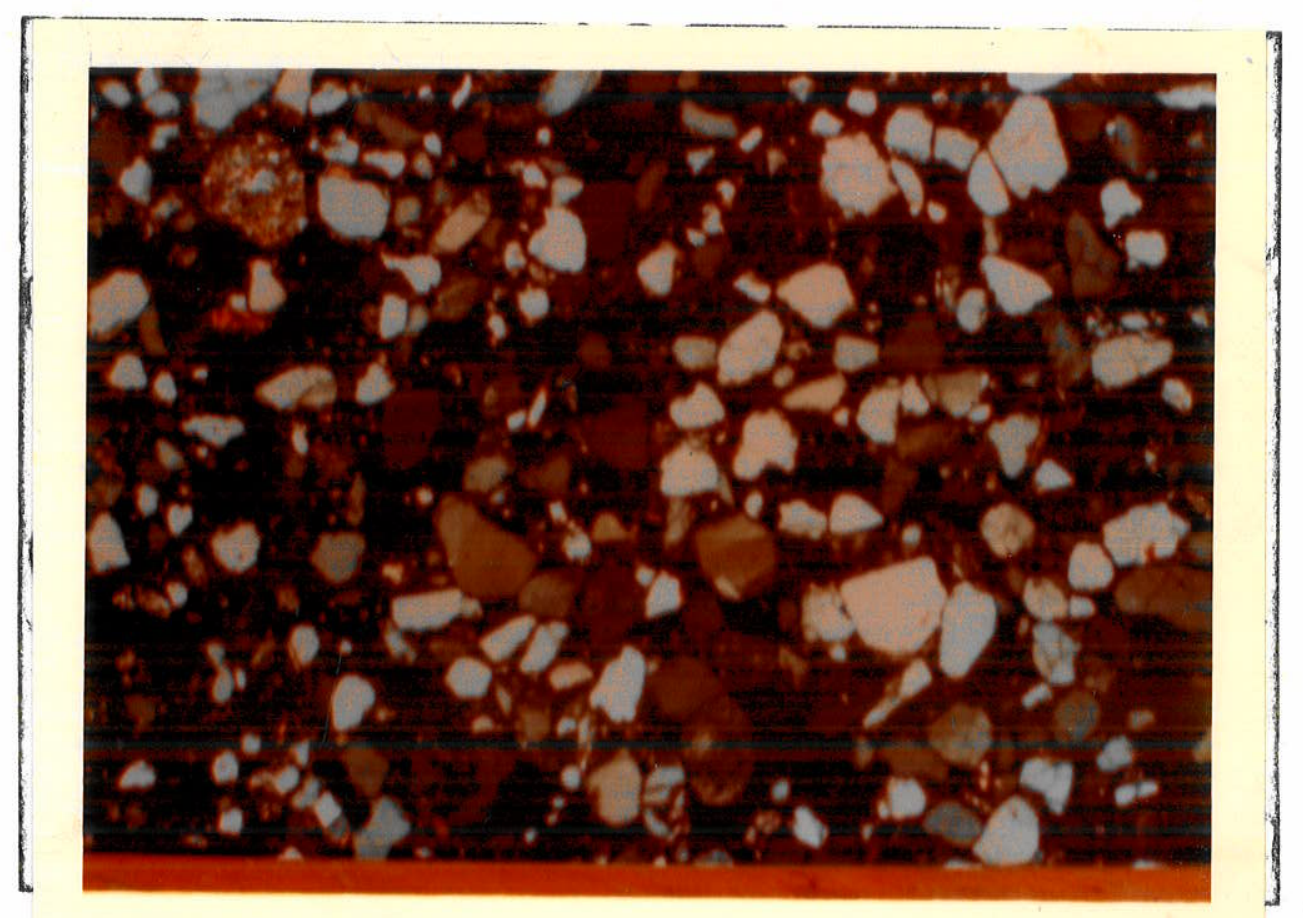

FOTO NO 24

LÂMINA No $11\left\{\begin{array}{l}\text { Aumento de } 35 x \\ \text { Nicöis cruzados }\end{array}\right.$

SONDAGEM No SR-26-A - ALTITUDE (m) - 250,12 - AMOSTRA No 41

PROFUNDIDADE (m) - 11,34 a 11,43

ALTITUDE (m) - 238,78

Arenito com estrutura compacta. Textura clästica. Granulometria varian do de areia fina e muito fina (grânulos variando desde 0,05 até 0,2mm). Grãos sub angulosos a arredondados, equidimensionais e prismäticos, de. quartzo e microclínio. Minerais acessôrios: calcedônia, opacos, epídoto (?), biotita, muscovita, Cimento constituído por argilo-mineral e hidröxidos de ferro. Localmente ocorrem lâminas com concentrações de cimento argilo-ferruginoso envolvendo os grânulos menores. Por difrato metria de raios- $X$, constatou-se que os minerais argilosos existentes sâo do grupo da montmorillonita. 


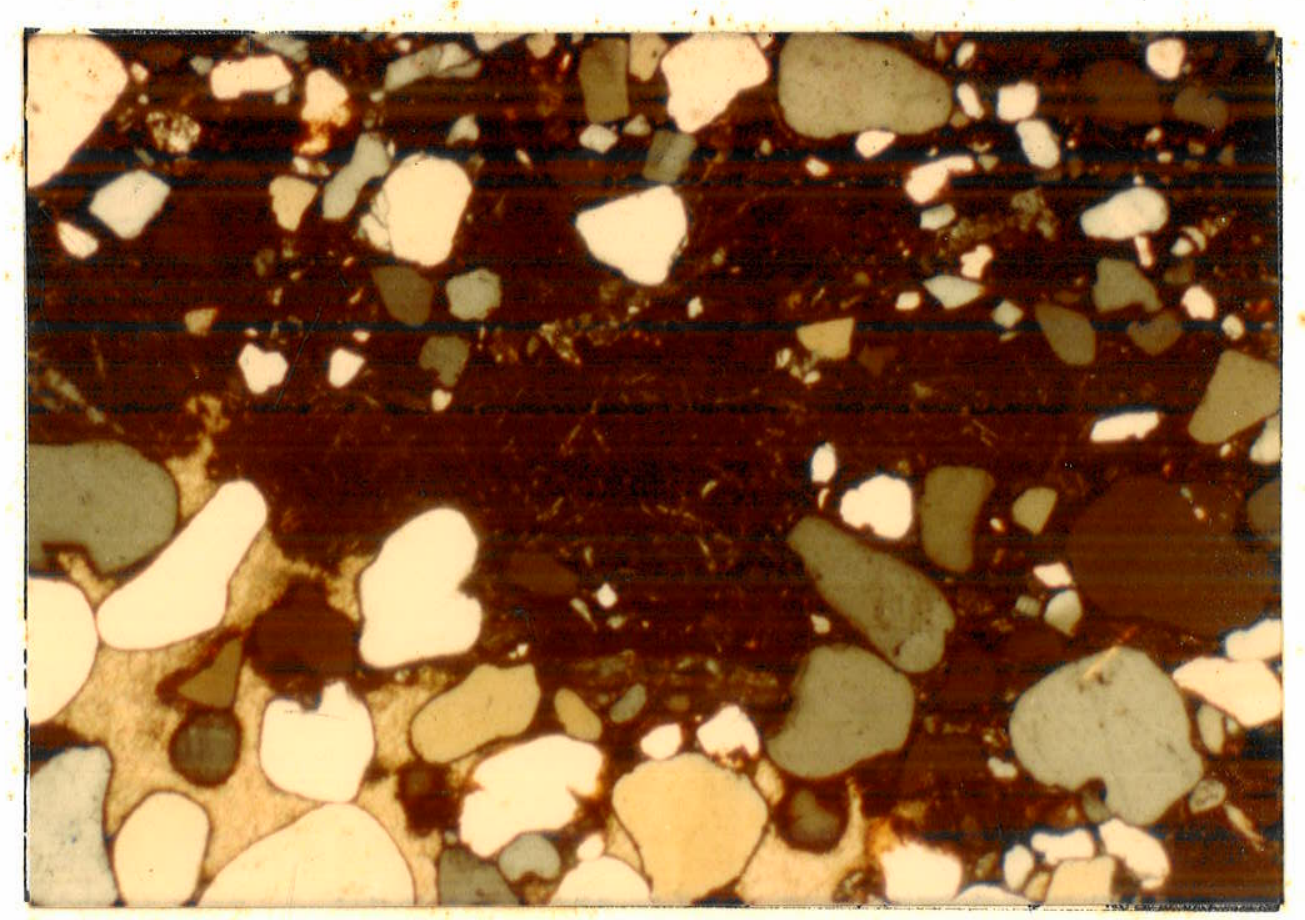

FOTO N. 25

LÄMINA No $12\left\{\begin{array}{l}\text { Aumento de } 35 x \\ \text { Nicöis cruzados }\end{array}\right.$

SONDAGEM NO SR-26-A - AMOSTRA NO 42

PROFUNDIDADE (m) - 12,53 a 12,68

ALTITUDE (m) - 237,59

Arenito com estrutura compacta. Textura clástica. Granulometria de areia fina a médiá. Grânulos sub arredondados e arredondados, comumente equidi mensionais e prismäticos, de diâmetro mẻdio entre 0,1 e 0,4 mm, cimentados por carbonato e secundariamente por argilo-mineral e hidröxidos de ferro, intercalados por grãos sub angulosos e arredondados, comumente equidimensionais e prismáticos, de diâmetro variävel entre 0,02 e 0,2 mm, dispersos em cimento ar gilo-ferruginoso, localmente associado a carbonatos. Os minerais detectados fo ram quartzo, feldspatos (microclínio + plagioclảsio), argilo-minerais + hidröxidos de ferro e carbonatos. Como acessörios foram encontrados calcedônia, opa cos, muscovita, biotita e fragmentos de basalto. Por difratometria de raios-x, o argilo-mineral encontrado pertence ao grupo da montmorillonita. No centro da lâmina, nota-se um fragmento de basalto entre o cimento, que apresenta variações de granulometria. No canto inferior esquerdo, aparece o cimento carbonāti co. 


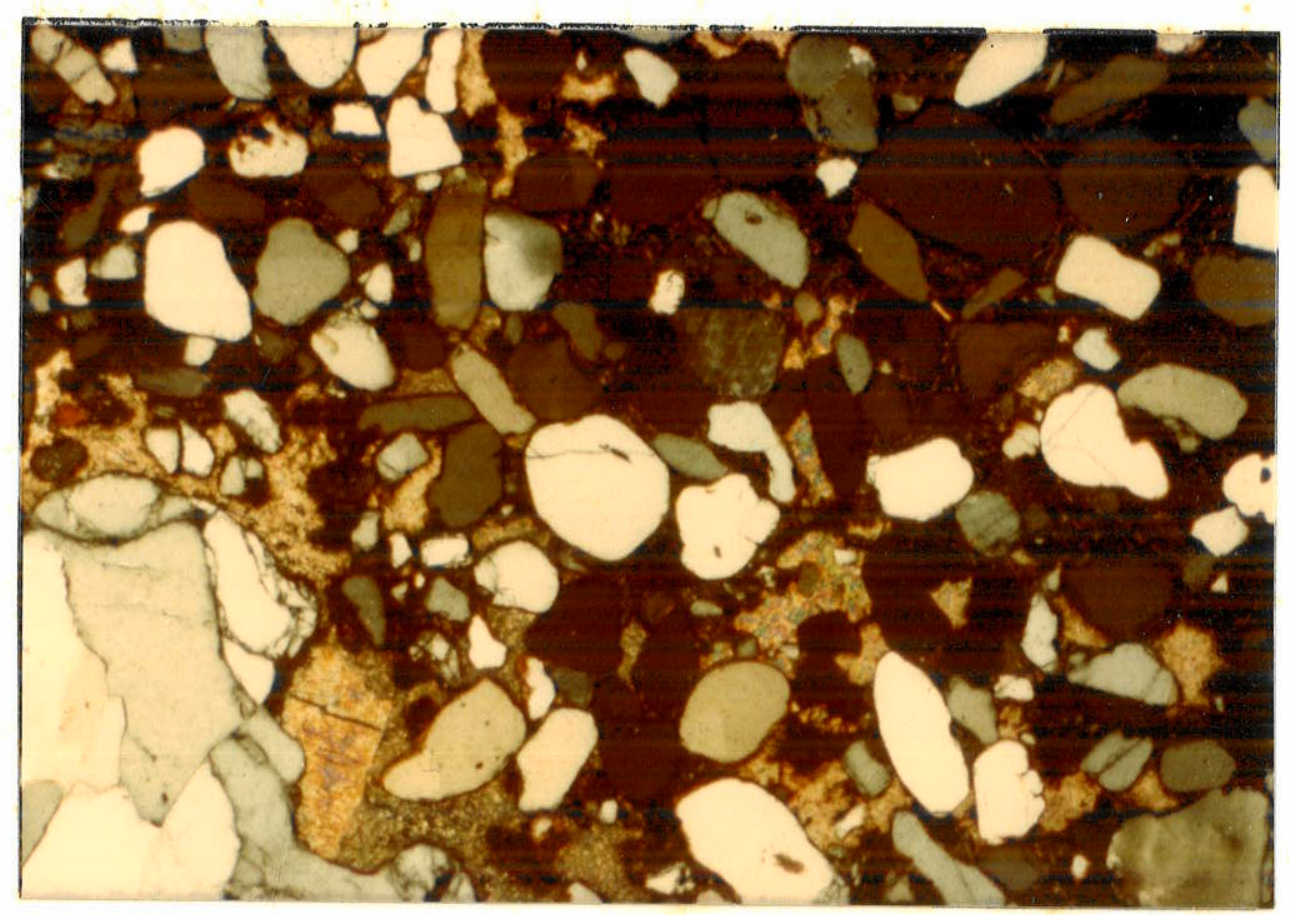

FOTO N․ 26

LÂMINA No $13\left\{\begin{array}{l}\text { Aumento de } 35 x \\ \text { Nicỏis cruzados }\end{array}\right.$

SONDAGEM No SR-26-A - AMOSTRA No 43

PROFUNDIDADE (m) - 15,22 a 15,36

ALTITUDE (m) - 234, 90

Arenito com estrutura compacta. Textura clästica. Granulometria de areia fina a mẻdia, com grânulos de diâmetro variảvel em torno de 0,2 mm, rara mente com $1,0 \mathrm{~cm}$, sub angulosos e arredondados, comumente equidimensionais e prismáticos, de quartzo e feldspatos (geralmente microclínio, mas também plagioclásio), argilo-minerais e hidróxidos de ferro e carbonatos. Acessöriamente ocorrem opacos, calcedônia, muscovita e biotita. O cimento ê representado pelo argilo-mineral e pelo hidröxido de ferro. Fragmentos arredondados e equidimensionais de quartzo ocorrem dispersos entre os grânulos. São comuns faixas irregulares, de espessuras sub centimëtricas e centimêtricas de material carboná tico associado ao cimento argilo-ferruginoso. 0 argilo mineral analisado por difratometria de raios $-x$, revelou-se como sendo do grupo da montmorillonita.

No canto inferior esquerdo, aparecem grãos de quartzo (tonalidade cinza) em contato com cimento carbonätico (tonalidade alaranjada). 


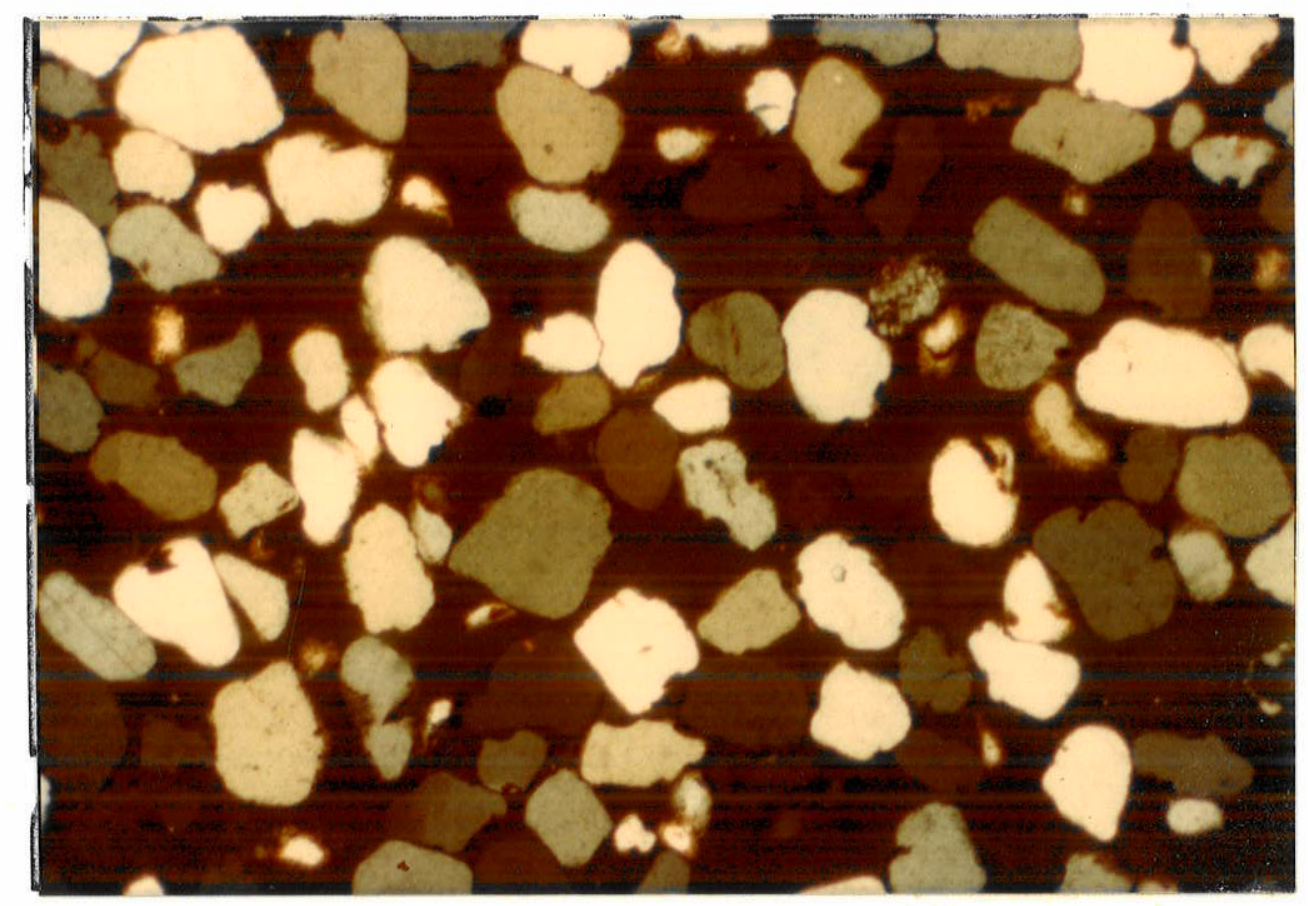

FOTO N ㅇ 27

LÂMINA No $14\left\{\begin{array}{l}\text { Aumento de } 35 x \\ \text { Nicóis cruzados }\end{array}\right.$

AFLORAMENTO (vide texto) - AMOSTRA No 44

ALTITUDE (m) - Aproximadamente 237,00

Arenito com estrutura compacta. Textura clästica. Granulometria de areia média a fina (grânulos com diâmetro mẻdio em torno de $0,3 \mathrm{~mm}$ ). Partículas sub arredondadas e arredondadas, equidimensionais e prismäticas, de quartzo e feldspato (microclínio). Acessoriamente outros minerais como calcedônia, biatita e opacos. 0 cimento ẻ representado por hidróxidos de ferro e argilo-mine ral, este detectado por difratometria de raios $-X$ como sendo dos grupos da montmorillonita e da caulinita. 
tos ricos em quartzo contendo 10 e $25 \%$ de feldspatos detríticos, enquanto que os "quartzo arenitos" ou "arenitos quartzosos" são aqueles nos quais os grânulos de quartzo, chert e quartzitos somam $80 \%$ ou mais do material silicatado detrítico, sendo que, os exemplares de granulação mais fina con tëm no minimo um pouco de feldspato, principalmente microclínio, ortocläsio ou albita. Os minerais acessörios típicos incluem apenas as espécies estäveis como o zircão, a turmalina e o rutilo, tão escassos que somente alguns poucos grânulos podem ocorrer em qualquer seção delgada, podendo a muscovita estar presente em pequenas quantidades, sendo a sua ocorrência principalmente o resultado de seleção local.

Das seções delgadas citadas, 5 referem-se a exemplares de arenitos feldspäticos e 6 a quartzo arenitos de Turner e Gilbert, muito embora a percentagem de feldspato nos primeiros esteja quase sempre no llmite inferior, dal acreditar-se que a grande maioria dos arenitos Caiuá seja real mente do tipo quartzo-arenitos.

Essas rochas referidas por Turner e Gilbert são em geral bem selecionadas, como o sào os Arenitos Caiua, onde imperam as características de areias bem lavadas, com muito pouco material argiloso. Depositaram-se quase que certamente, em ambientes estäveis ou de lenta subsidência, onde as taxas de deposição possibilitaram que as particulas fossem sempre retra balhadas, de modo que antes do enterramento final os materiais argllosos fossem eliminados. Em tạis condições, os grânulos de areia tendiam a tor nar-se quase arredondados ou bem arredondados.

Segundo ainda Turner e Gllbert, a consolidação dos quartzo areni tos pode ter-se originado atravës de dois processos diferentes entre si. 0 primeiro, baseado exclusivamente por cimentação, conduz a que os grânulos detríticos fiquem unidos apertadamente uns aos outros por minerais autigênicos (cimento calcedônico, carbonätico ou mesmo minerais de argila). Este material aglutinante pode ser representado pelo cimento propriamente dito, pelo quartzo secundärio ou ambos juntamente.

O segundo processo de consolidação è aquele durante o qual hä um empacotamento apertado dos grânulos detríticos sob pressão, usualmente associado com cimentaçäo de importância relativamente menor. Parece serem os Arenitos Caiuá sofrido o segundo tipo de consolidação, já que o seu ci mento $\vec{e}$ relativamente pobre ou inexistente. As vezes os crescimentos secun därios de quartzo desenvolvem-se atê que preencham totalmente os espaços porosos originais da areia. Outras vezes, no entanto, tals crescimentos não são tão grandes, deixando de preencher portanto por completo os poros da areia original. Neste caso, terminam ao longo dos lados das cavidades, por 
faces usualmente de prismas ou romboedros, que podem passar desapercebidas no exame das seções delgadas, a menos que estejam quase normais ao plano das mesmas. Quando o cimento ê carbonätico, os espaços porosos da areia são geralmente completamente cheios com uma argamassa de carbonato.

Especificamente quanto aos cimentos, Turner e Gilbert afirmam que muitos minerais diferentes podem cristalizar em uma areia depois de sua deposição, mas somente alguns sãa abundantes como material de cimenta ção. Entre estes estão os carbonatos (calcita, dolomita, ankerita e sider ta), o quartzo, a calcedónia, a opala, anidrita, gipso, barita e colofãnio (apatita). Os carbonatos e o quartzo são de todos os citados os mais impor tantes. Alguns outros minerais autigênicos, tais como os feldspatos alcali nos, a pirita, a clorita e a laumontita, contribuem para a cimentação, mas muitas vezes nenhum deles constitui o cimento principal.

A presença da matriz argl losa parece inibir a formação de cimento químico, quem sabe por causa de sua balxa permeabilidade. Por outro la do, a composição da pröpria arela influencia de algum modo a espécle de ci mento que irá se precipitar. O cimento quartzoso $\vec{e}$ abundante nos arenitos finos ricos em quartzo, crescendo na forma de incorporações secundārias aos grânulos de quartzo, como jä se discutiu. Da mesma forma, os feldspatos au tigênicos quando ocorrem nos arenitos estaräo presentes quando ocorre tam bëm o feldspato detrítico, desenvolvendomse tambëm sob a forma de cresci mentos secundärios sobre os grânulos detríticos. Os cimentos carbonáticos formam-se, ao que parece, sempre que a areia tenha contido o carbonato pri märio, mas ê nossa opinião de que tambêm ele possa aparecer a partir de soluçōes concentradas migrantes em sentida ascencional, a partir de substratos que sejam fontes de material carbonätico. Pode ser esta a explica ção da presença de carbonato autígeno nos arenitos Caiuä, principalmente quando se constata a sua presença principalmente no terço inferior do paco te de arenitos, sobrejacente aos basaltos.

Consideram-se oportunos alguns arrazoados acerca da evolução pedogênica típica de regiões tropicais, que sem dúvida age sobre as rochas sedimentares aqui estudadas.

Sabe-se que os solos lateríticos são essencialmente produtos de intemperismo tropical ou subtropical. E provävel que Russel (1889) do U.S. Geological Survey, discutindo sobre a deterioração das rochas ao ar e a origem da cor vermelha de certas formações rochosas nos Estados Unidos è quem tenha primeiramente enfatizado que em climas tropicais ümidos, com altas temperaturas, a percolação de ägua atravës das rochas funciona como um poderoso solvente, e que o intemperismo ë mais räpido em regiōes quen 
tes que em frias e maior em regiôes ümidas que äridas. Tambẻm Holland (1903) sugeriu que durante o intemperismo de silicatos aluminosos nos trô picos, são removidos, em solução, a sílica, os cätions alcalinos e alcalino-terrosos, enquanto que os öxidos de ferro e aluminio desidratam-se, pre cipitam-se e permanecem.

Mais na atualidade, Gidigasu (1976) relata que estudos baseados em experiências de campo, mostram que as características geotécnicas e o comportamento na prätica de solos lateríticos são influenclados bastante pelo modo de formação (gênese), características morfológicas, grau de intemperismo e composição química e mineralägica. Cada um desses fatores pode, por sua vez estar relacionado com sistema de alteração determinado pelo efeito conjunto de parâmetros pedogenéticos (material original, cll ma, vegetação).

A importância prática dessẹs inter-relacionamentos reside no fa to de que se pode estabelecer a semelhança de grupos de solos lateríticos ocorrendo em diferentes äreas, de tal maneira que as propriedades geotécni cas que tiverem sido adequadamente compreendidas numa área, poderão ser aplicadas a solos similares alhures.

A engenharia pedolögica que tem aplicações regionais e locais começa com um conhecimento das rochas e das condiçöes de intemperismo, dos quais se deduz logicamente a natureza dos produtos finais, especialmente os argilo-minerais. Consequentemente, desde que esses exercem influência ponderävel nas propriedades geotēcnicas como, plasticidade, resistência ao cisalhamento, compressibilidade, etc., a pedogênese de solos laterít $\cos$ e a influência dos fatores pedogenéticos são de considerável signif cância para a geotêcnica de solos lateríticos. Jả se propôs que as características geotécnicas e o comportamento de campo de solos lateríticos po dem ser interpretados à luz de alguns ou de todos os parâmetros enumerados a seguir: 1) Gênese e fatores pedogenêticos;2) Grau de intemperismo; 3) Argilo-minerais e sua percentagem. Aqui, o termo "grau de intemperismo" ē usado num sentido amplo, para incluir os graus de decomposição, enriquecimento em sesquióxidos e desidratação (secamento e endurecimento).

Acredita-se que nos Arenitos Caiuä estão se processando fenômenos de evoluçäo climäticas de caracteristicas essencialmente tropicais, comprovados pela presença de öxidos de ferro (hematita) como produto final e irreversivel a se superpor à tênue cimentação natural dos referidos are nitos, o que torna inadiävel a necessidade de se proceder profundos e sis temäticos estudos nesse sentido, com os referidos materiais. 


\section{Granulometria}

Foram ensaiadas as amostras pertencentes ao Conjunto 1.

As curvas granulométricas das 12 amostras ensaiadas não represen tadas pelas Figuras nümeros 8 a 13: Na tabela 5 , ve-se um resumo dos componentes das frações granulométricas areía, silte e argila, em cada uma das amostras.

Conclui-se, dos dados expostos, que os arenitos analisados pouco diferem quanto à sua composição granulométrica, apesar de terem sido ex traídos a diversas profundidades dentro do pacote e em regiões diferentes dentro do Pontal. Nota-se apenas que os exemplares de nümeros 6,7 e 8 , possuem uma percentagem de silte um pouco mais elevada que os demais, sendo que o nümero 7 apresenta um total de $30 \%$ de finos em sua constituição, o que não deixa de ser significativo. Deduz se ainda que a granulometria não tem grande influência na rotulação dos arenitos resistentes, brando e medianamente resistentes, devendo ser do cimento a responsabilidade de tais comportamentos. Foi observado, durante os ensaios de granulometria, que algumas amostras mais argilosas, particularmente as de nümeros $4 \mathrm{e} 7$, apresentaram bastante resistência ao processo de destorroamento, ou seja, de se desmanchar a amostra para a realização do ensaio. Isto deve-se, como jä foi dito, à eficiência maior do cimento na aglutinação dos grãos, nas amostras citadas.

\section{Densidade dos grãos}

As amostras ensaiadas foram as do Conjunto 1.

Foram realizados, para cada amostra, dois ensaios e efetuada a mëdia aritmëtica dos dois resultados. Os resultados são os da tabela 6 .

Calculados a média e a desvio padrão dos resultados expostos, verifica-se que esses parämetros confirmam a relativa homogeneidade do Are nito Caiuä, mesmo de profundidades e locais diferentes, no que se refere à densidade dos seus grãos componentes,

\section{Massa especifica aparente seca}

Para este ensaio, as amostras utillizadas foram as dos conjuntos 1,2 e 3. 


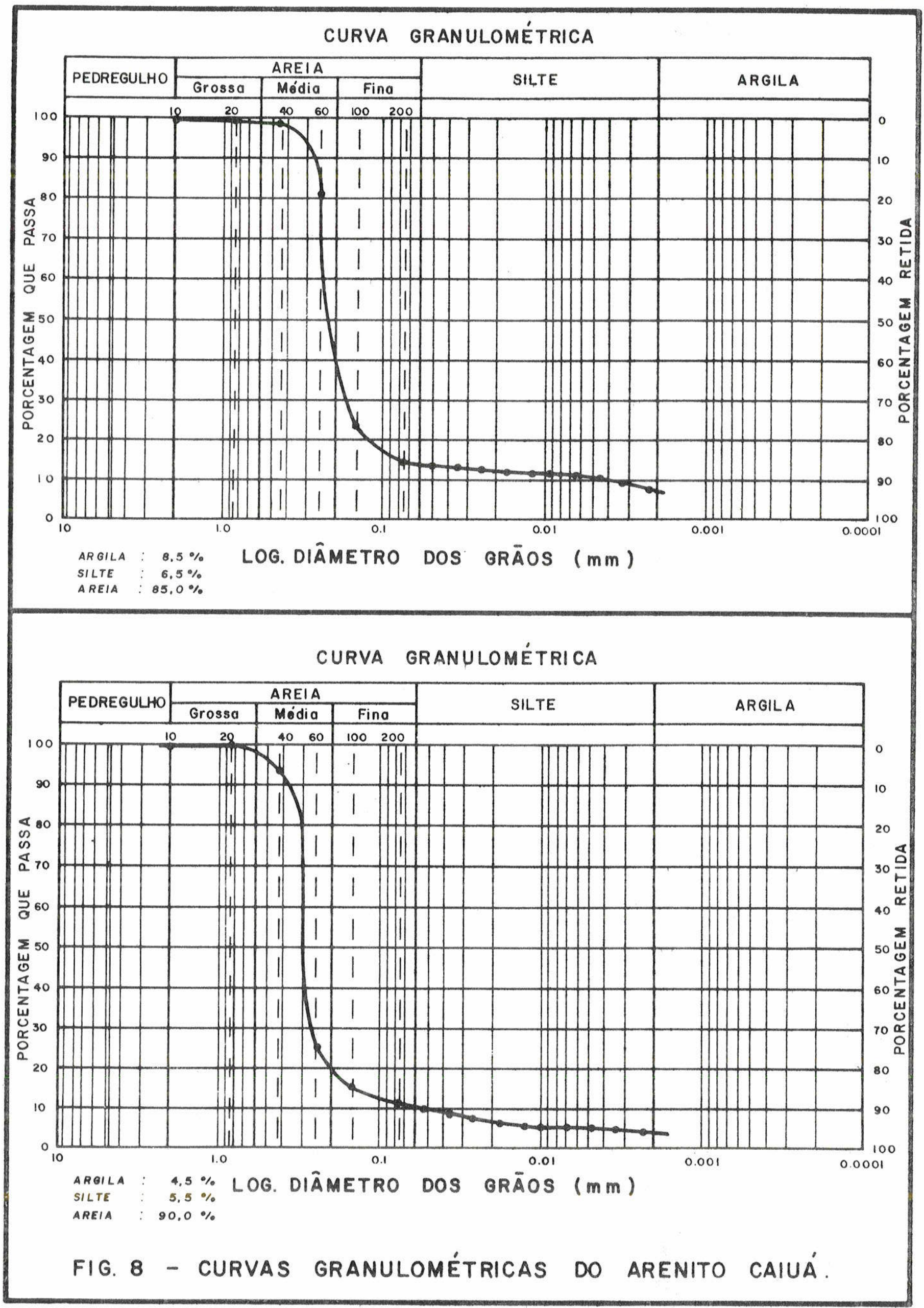


CURVA GRANULOMÉTRICA

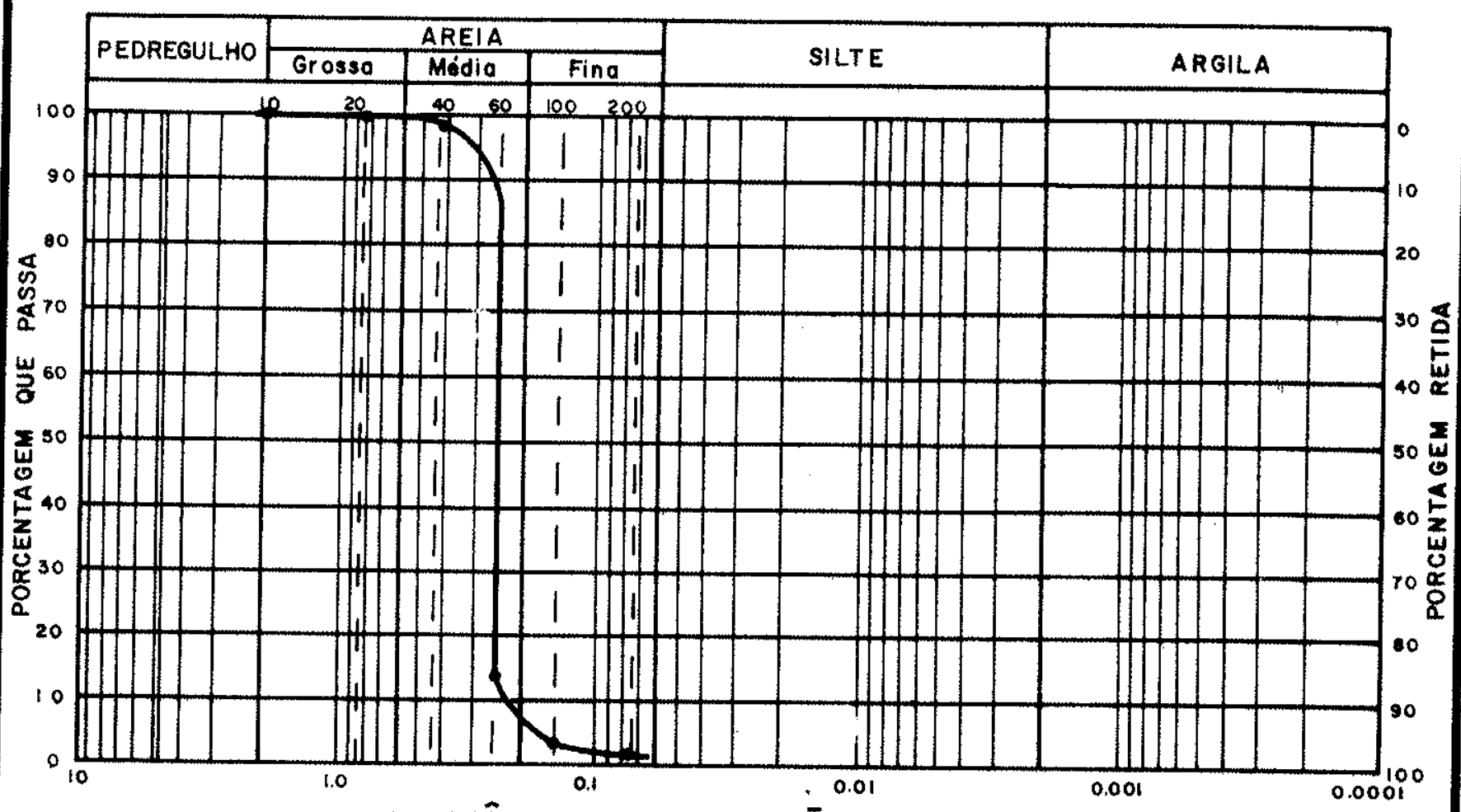

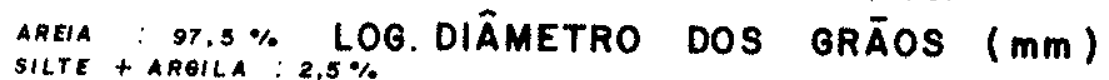

CURVA GRANULOMÉTRICA

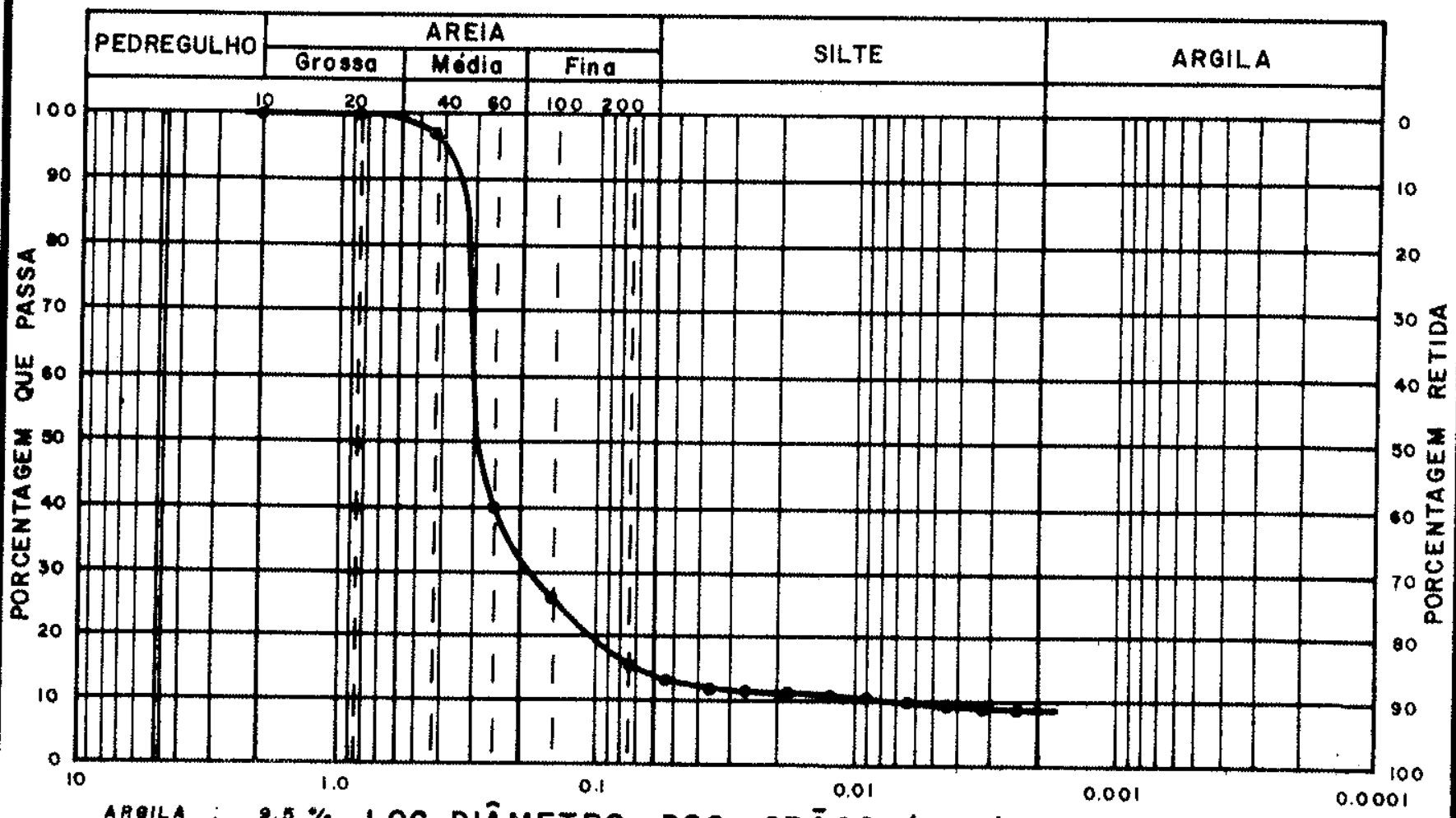

SILTE : $5.5 \%$ LOG. DIÂMETRO DOS GRĀOS $(\mathrm{mm})$

AREIA : $85.0 \%$

FIG. 9 - CURVAS GRANULOMÉTRICAS DO ARENITO CAIUÁ 
CURVA GRANULOMÉTRICA

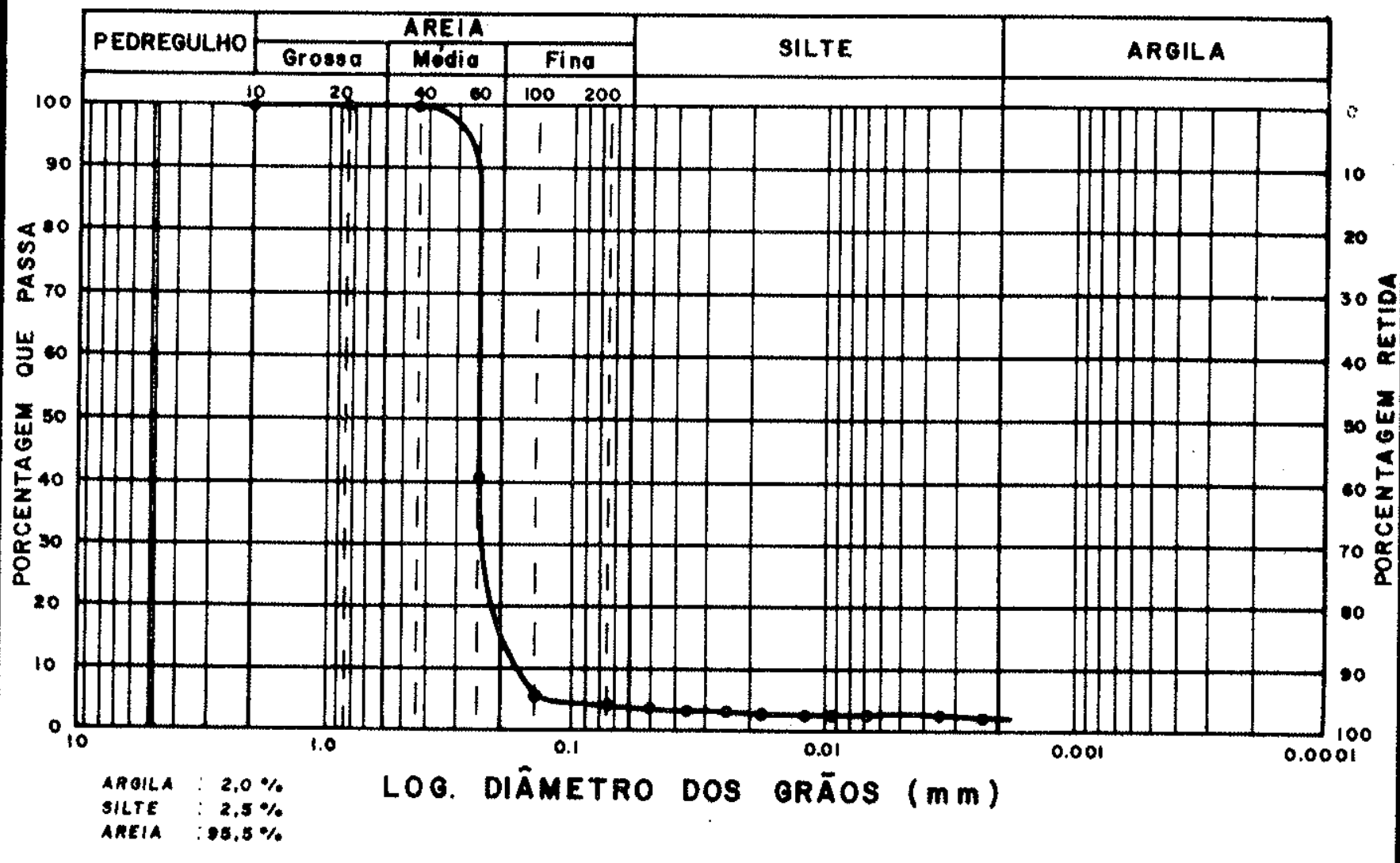

CURVA GRANULOMÉTRICA

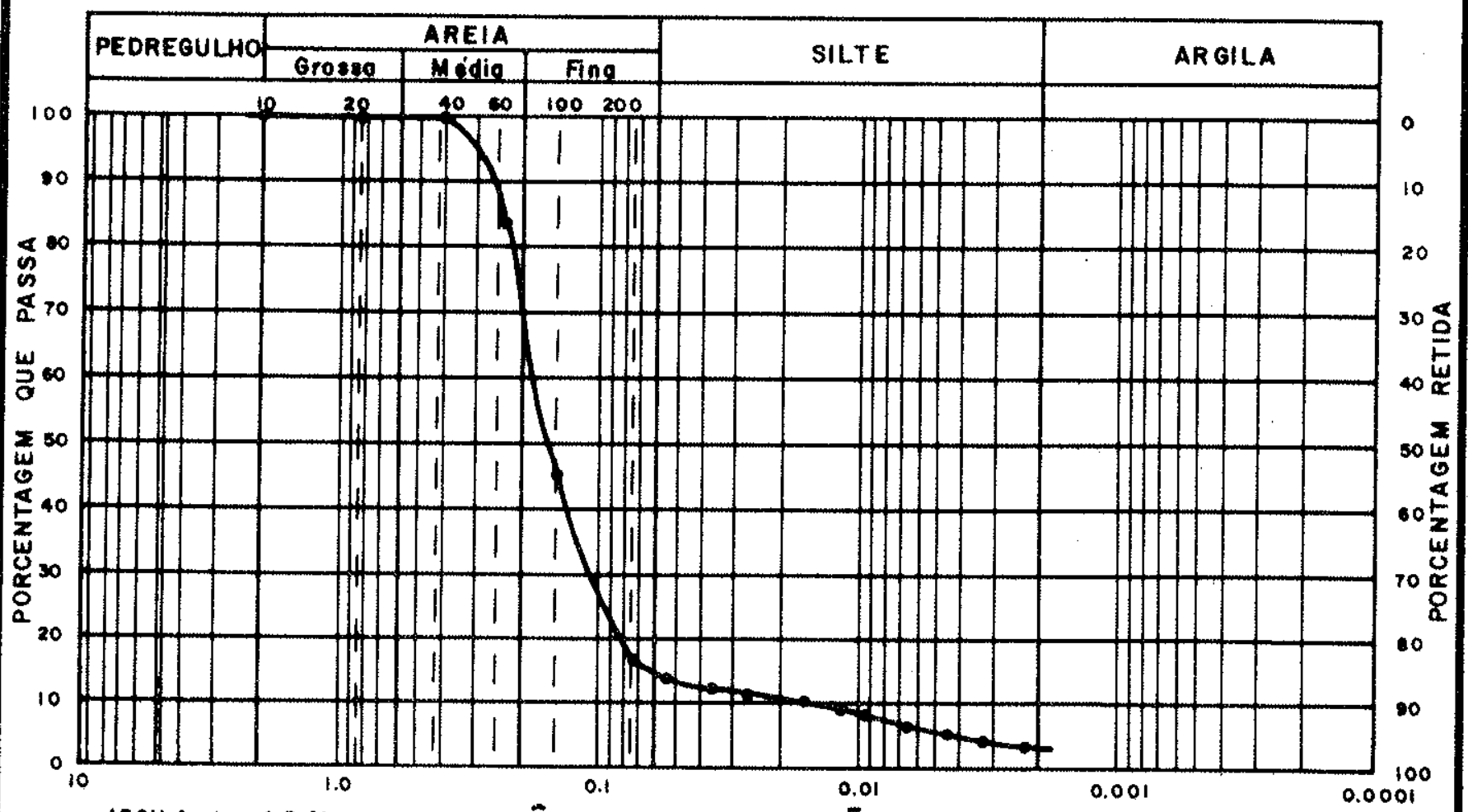

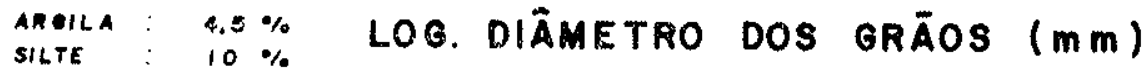

AREIA : $85,5 \%$

FIG. 10 - CURVAS GRANULOMÉTRICAS dO ARENITO CAIUÁ. 


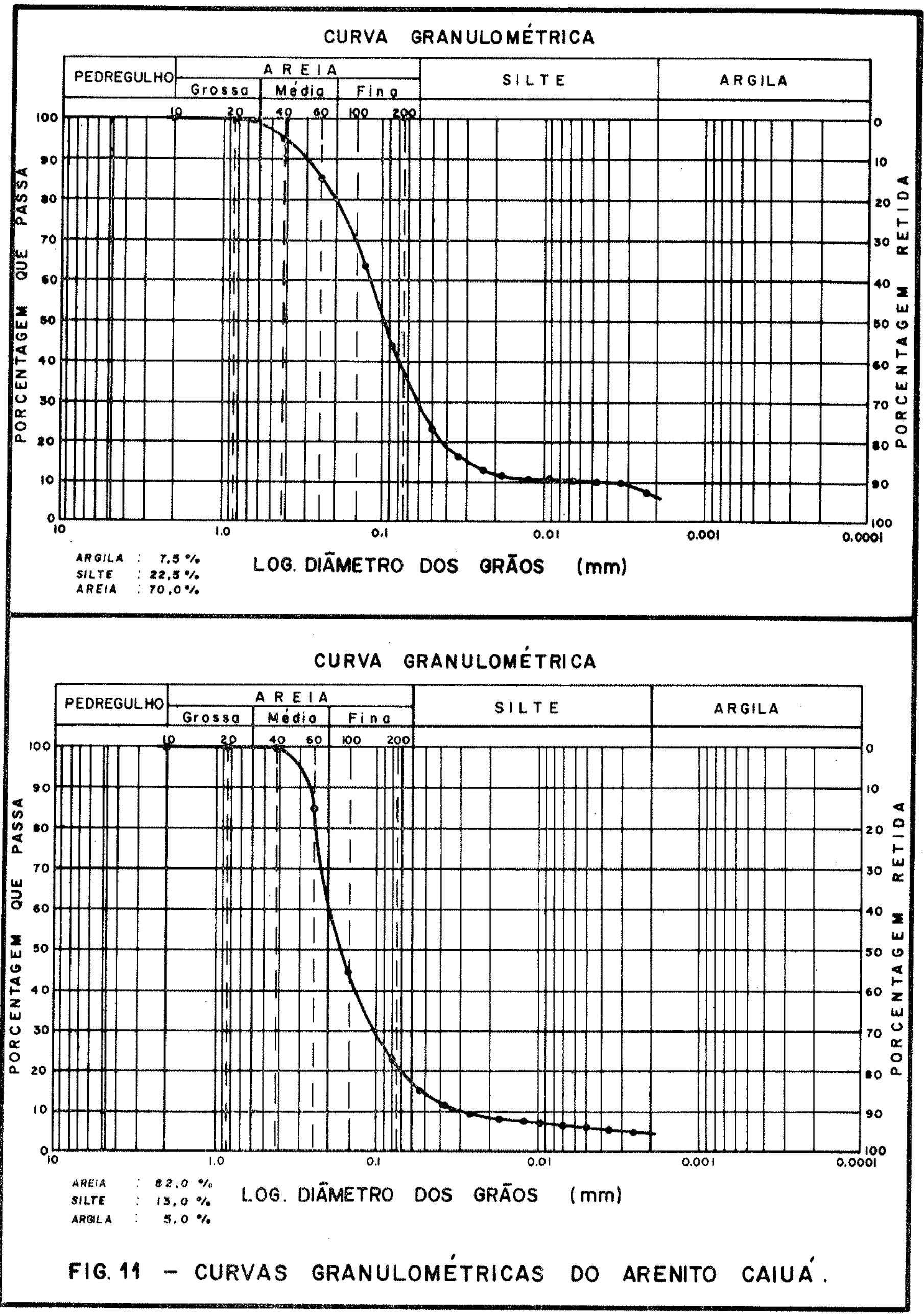


CURVA GRANULOMÉTRICA

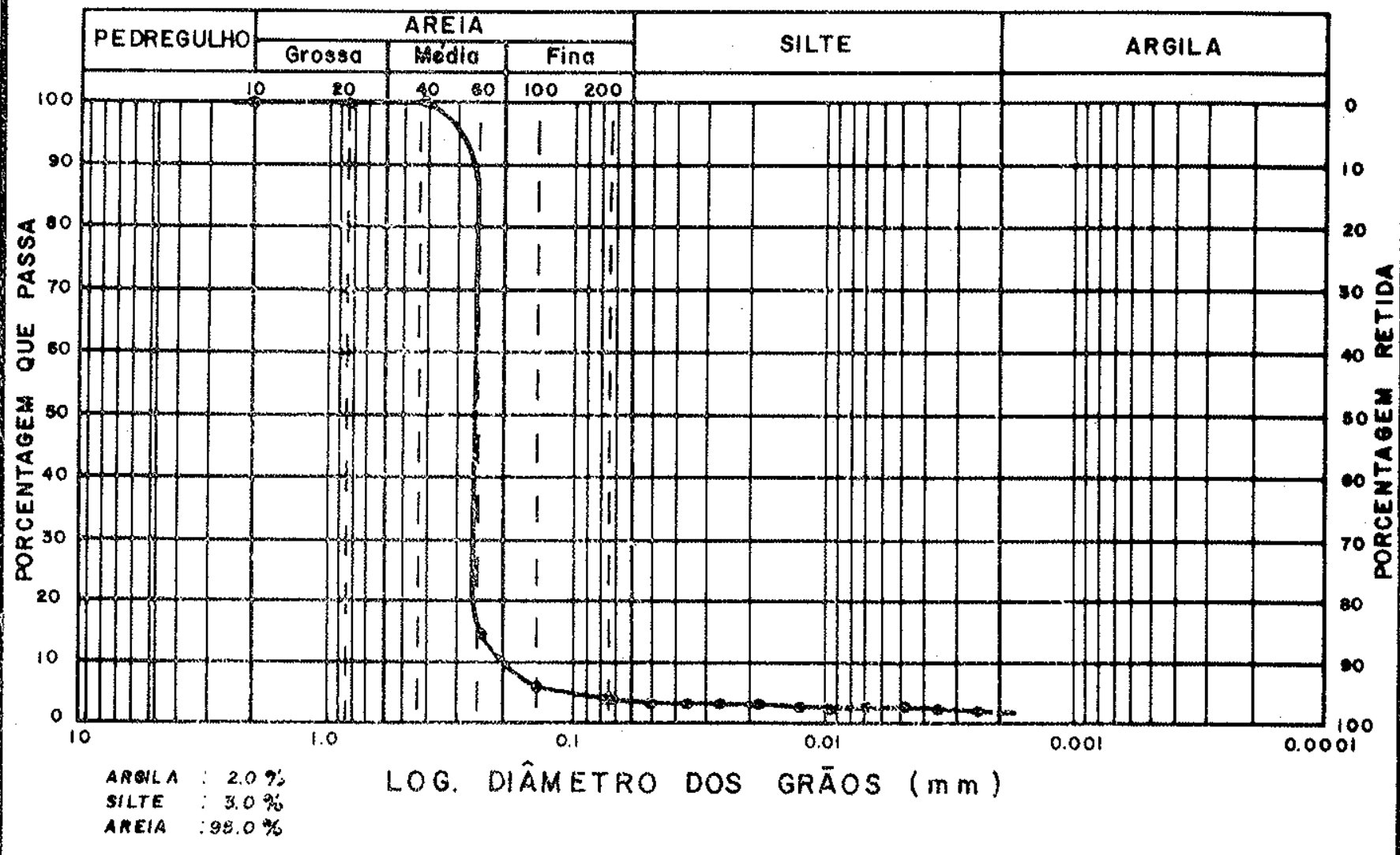

CURVA GRANULOMÉTRICA

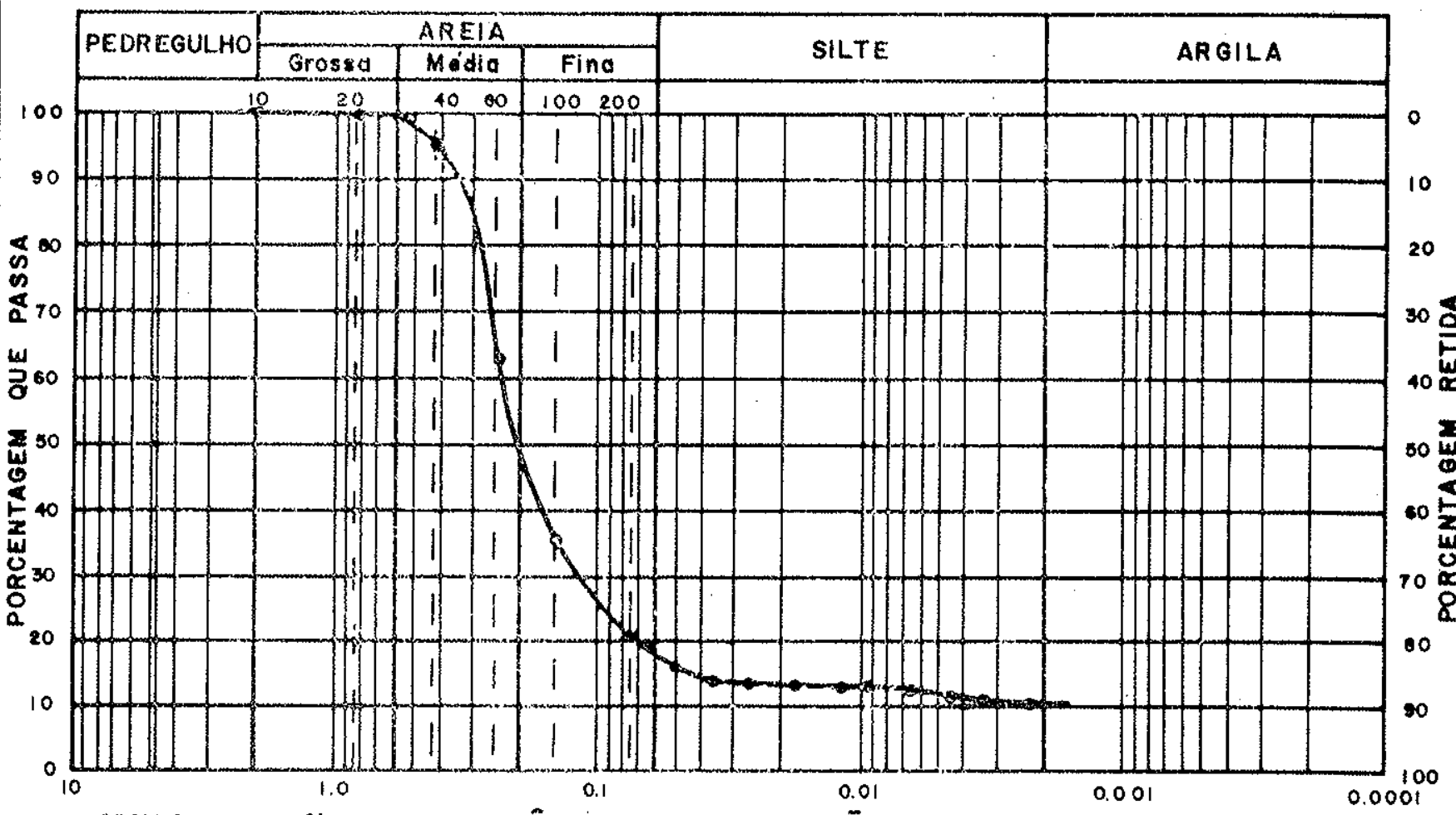

AHQLLA: $10.0 \%$ LOO. DIÂMETRO DOS GRÄOS ( $\mathrm{mm}$ )

AREIA : AR.O\%

FIG. 12 - CURVAS GRANULOMÉTRICAS DO ARENITO CAIUÁ. 
CURVA GRANULOMÉTRICA

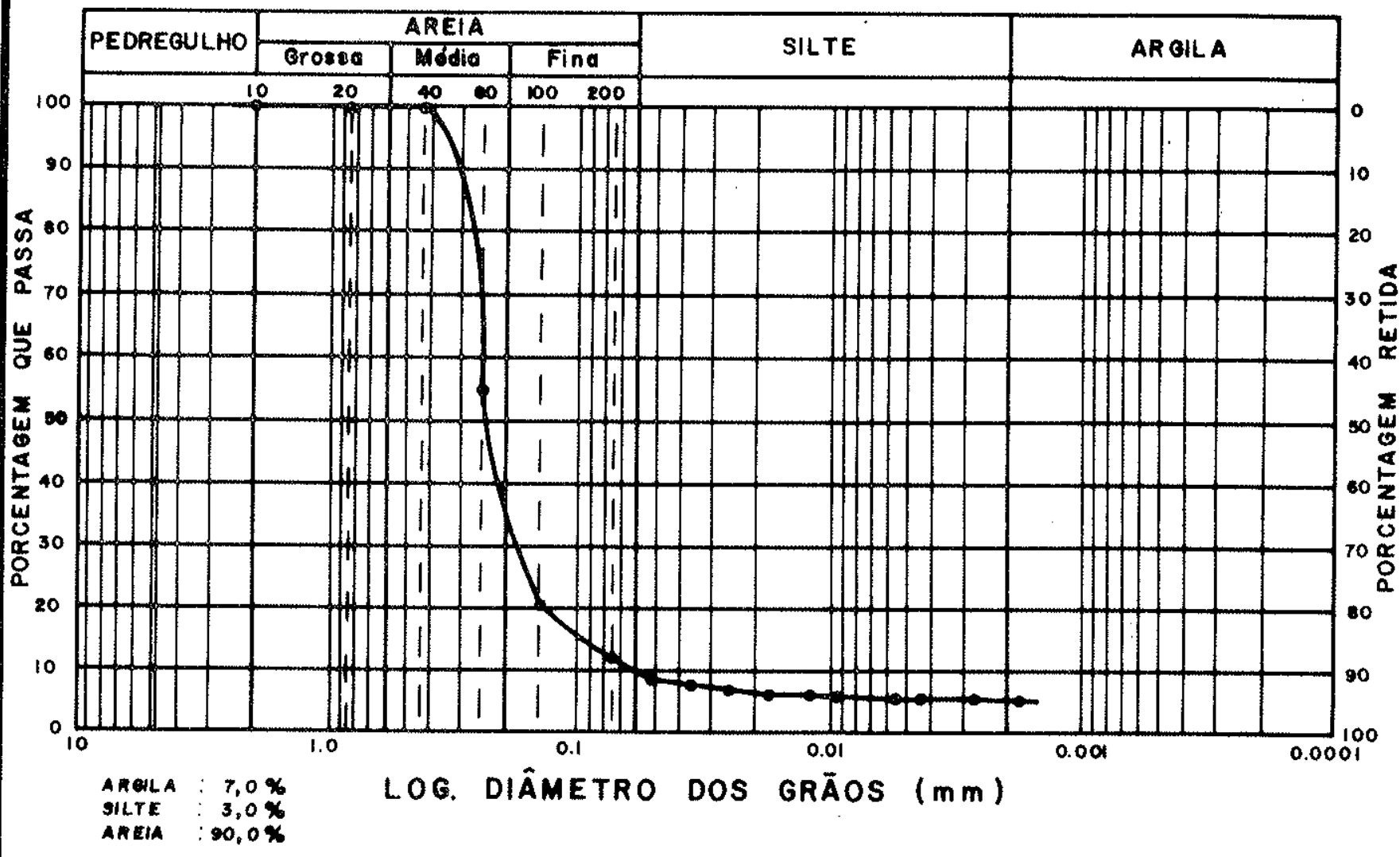

CURVA GRANULOMÉTRICA

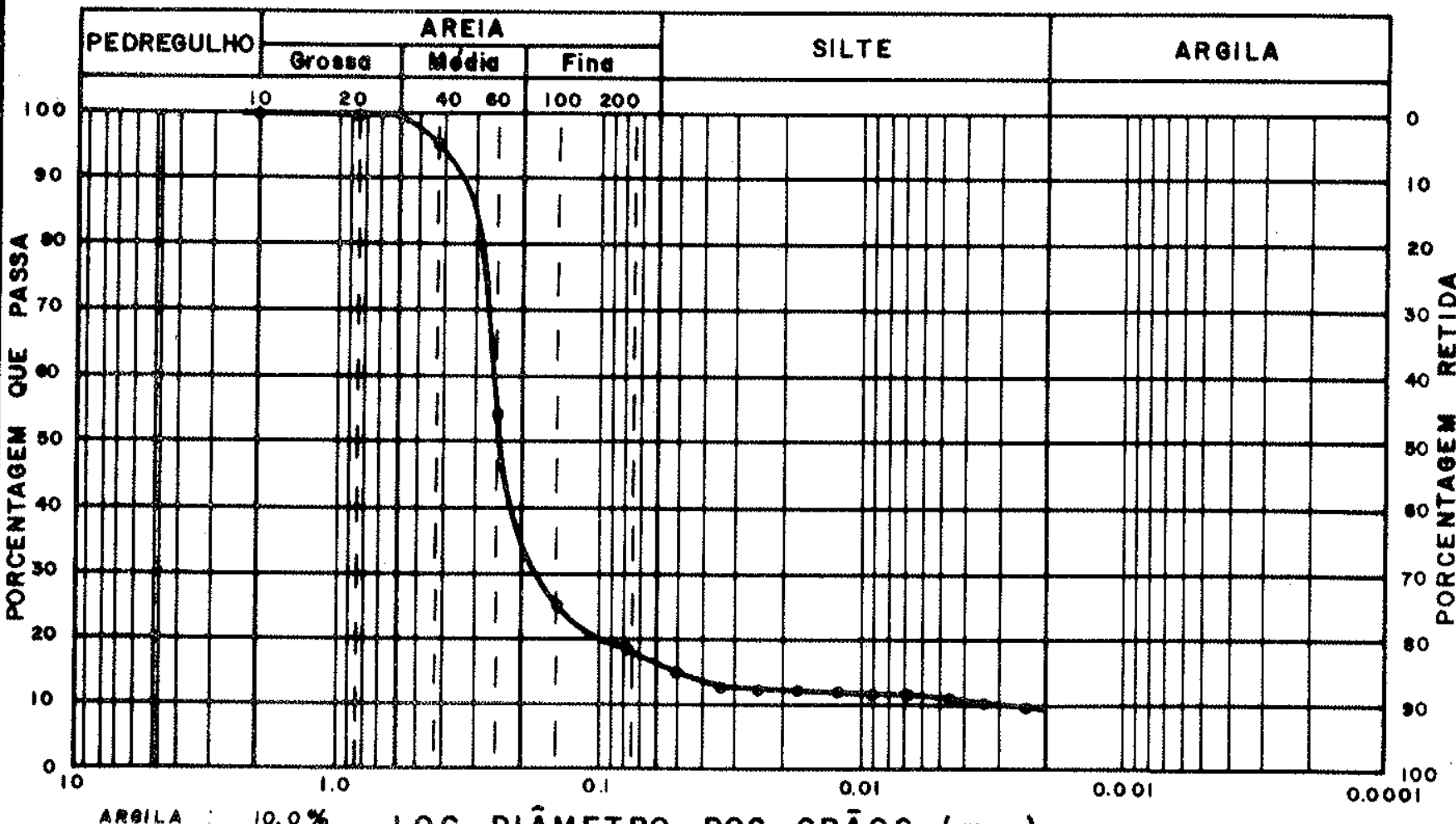

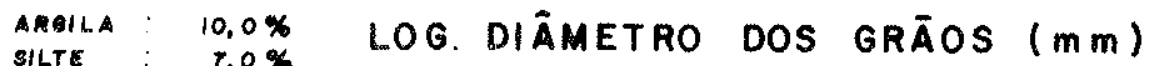

AREIA: $05,0 \%$

FIG. 13 - CURVAS GRANULOMÉTRICAS DO ARENITO CAIUÁ 
Tabela 5

Percentagens das frações grossas e finas em amostras dos Arenitos Caiuá

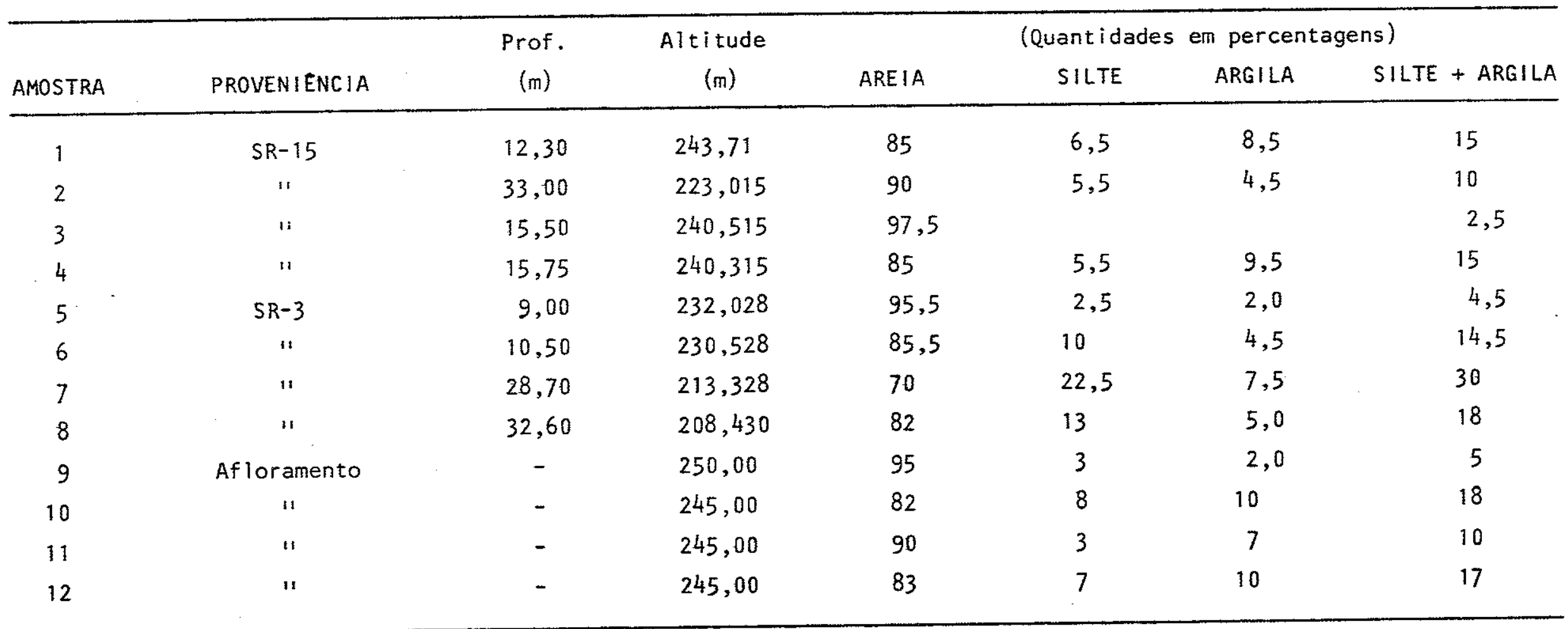


Tabela 6

Densidade dos grãos dos Arenitos Caiuã

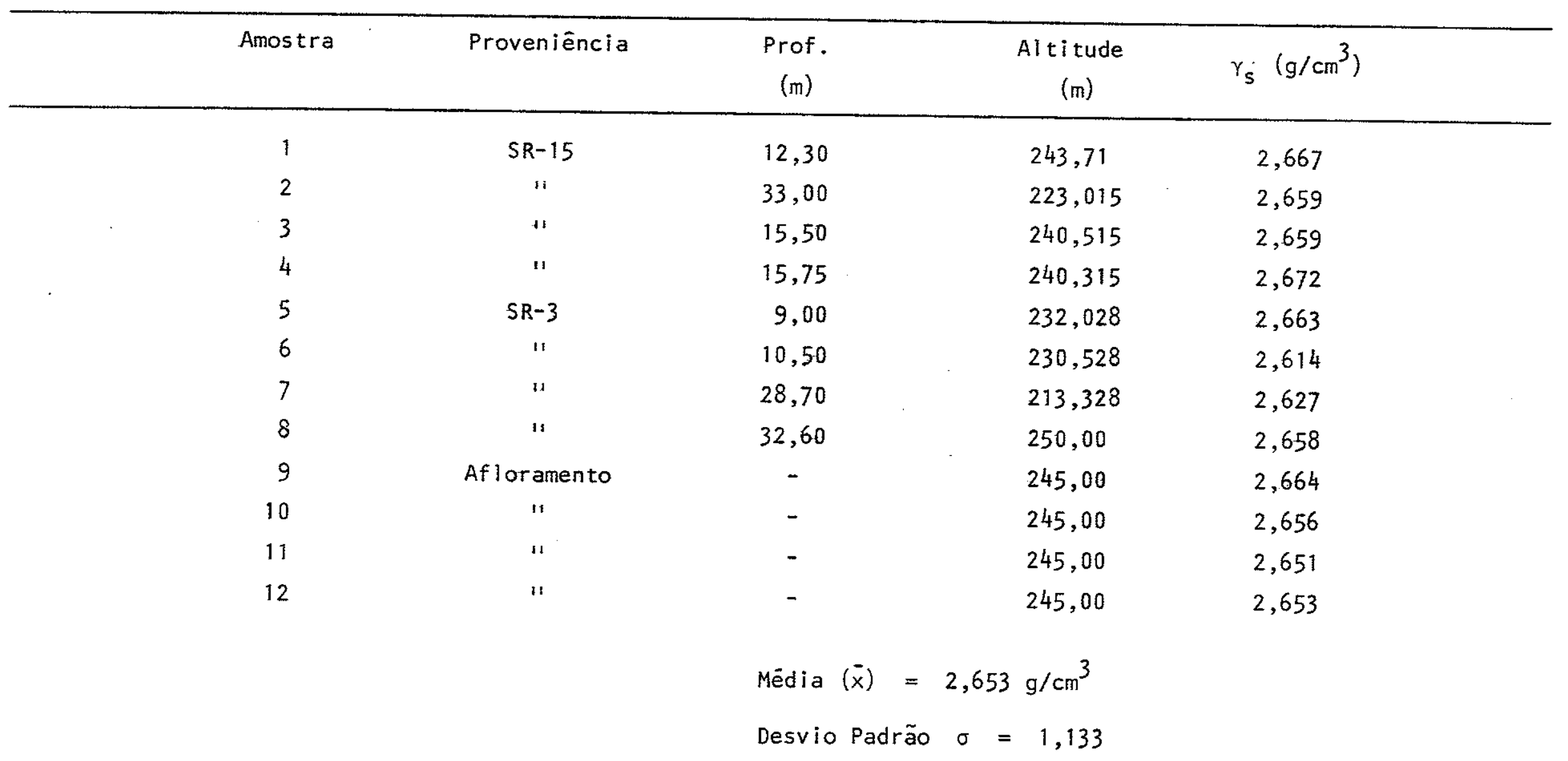


Tabela 7

츨

A - Conjunto 1
Massa especifica aparente seca

dos Arenitos Caiuá

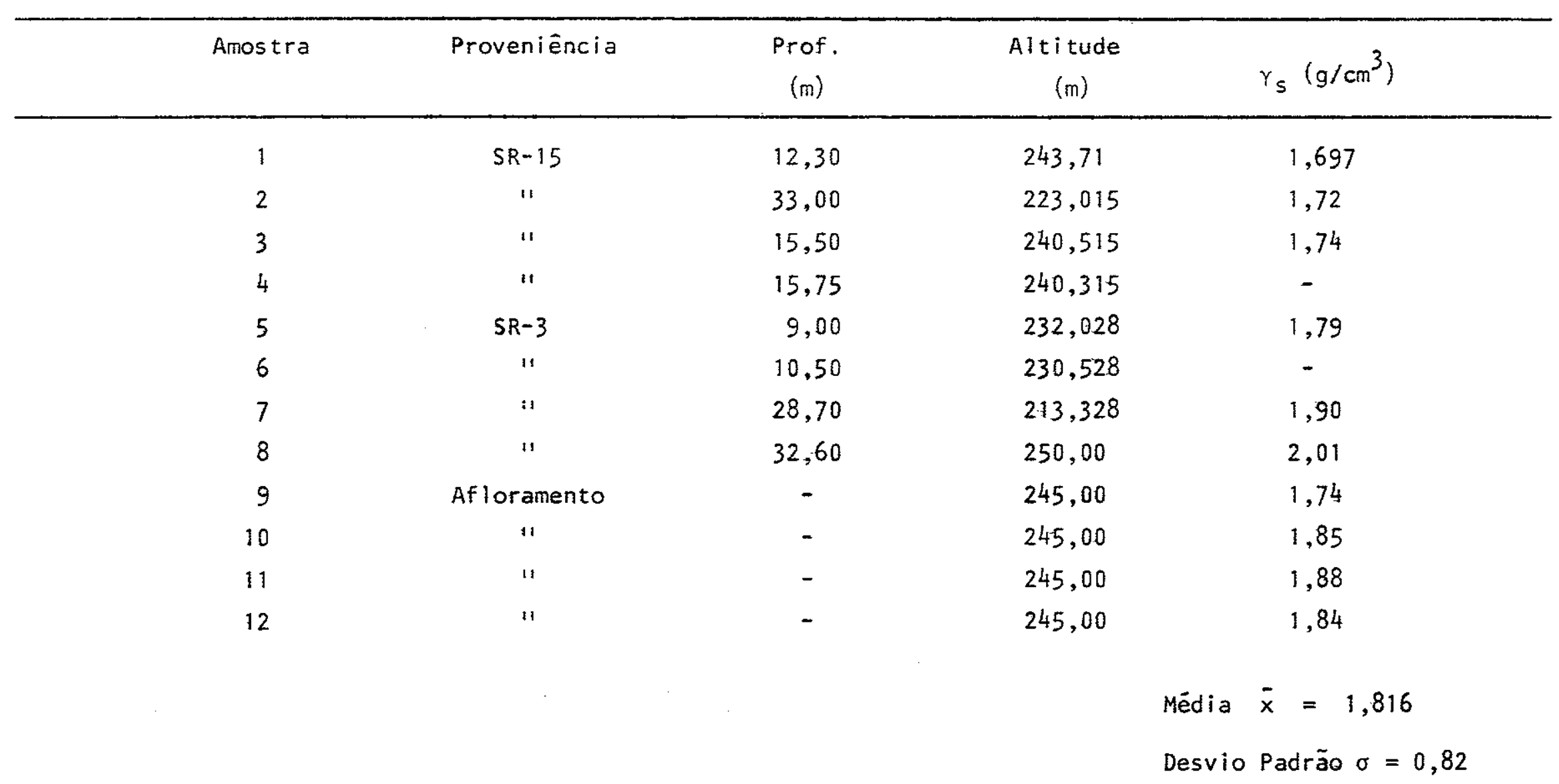


B - Conjunto 2

Tabela 8

Massa especifica aparente seca dos Arenitos Caiuä

a) Amostras provenientes do local 11

\begin{tabular}{lc}
\hline 1 - Faixa granulomëtria & $3>\phi>2^{\prime \prime}(7,62>\phi>5,08 \mathrm{~cm})$ \\
\hline Exemplares & 10 \\
Mëdia $\bar{x}$ & 1,77 \\
Desvio padrão $\sigma$ & 2,20 \\
\hline
\end{tabular}

b) Amostras provenientes do local 11

Tabela 9

Massa especifica aparente seca dos Arenitos Caivä

\begin{tabular}{lcc}
\hline Faixas granulométricas & $\begin{array}{c}1 / 2>\phi>11 \\
(3,81>\phi>2,54 \mathrm{~cm})\end{array}$ & $\begin{array}{c}21 / 2>\phi>2,3 \\
(6,35>\phi>5,08 \mathrm{~cm})\end{array}$ \\
\hline Exemplares & 20 & 30 \\
Mëdia $\bar{x}$ & 2,02 & 2,00 \\
Desvio padrão o & 3,03 & 5,35 \\
\hline
\end{tabular}

c - Conjunto 3

Ensaios realizados com testemunhos de sondagens rotativas, dos. locais de amostragem 111 e $V$. 
Tabela 10

Massa especifica aparente seca dos Arenitos Caiuã

a) Faixa granulomëtrica $2>\phi>11 / 2^{\prime \prime}(5,08>\phi>3,81 \mathrm{~cm})$

\begin{tabular}{|c|c|c|c|c|c|}
\hline $\begin{array}{l}\text { SONDAGEM } \\
\text { NOMERO }\end{array}$ & $\begin{array}{l}\text { AMOSTRAS } \\
\text { NOMERO }\end{array}$ & $\begin{array}{c}\text { PROFUND IDADE } \\
(\mathrm{m})\end{array}$ & $\begin{array}{l}\text { COTA } \\
(\mathrm{m})\end{array}$ & EXEMPLARES & $\begin{array}{cc}\text { MEDIA } & \text { DESVIO PADRÃO } \\
\bar{x} & \sigma\end{array}$ \\
\hline$S R-3$ & 18 & $\begin{array}{c}24,88 \\
a \\
25,04\end{array}$ & 216,15 & 5 & $\begin{array}{l}\text { Amostras totalmente } \\
\text { desagregadas em me- } \\
\text { nos de } 2 \text { horas de } \\
\text { saturação }\end{array}$ \\
\hline \multirow[t]{2}{*}{ Idem } & 19 & $\begin{array}{c}27.65 \\
a\end{array}$ & & 4 & \\
\hline & & 27,87 & 213,38 & 4 & $2,14 \quad 0,057$ \\
\hline$S R-5$ & 25 & $\begin{array}{c}11,74 \\
a \\
11,90\end{array}$ & 226,40 & 3 & $\begin{array}{l}\text { Amostras totalmente } \\
\text { desagregadas em me- } \\
\text { nos de } 2 \text { horas de } \\
\text { saturação }\end{array}$ \\
\hline \multirow[t]{2}{*}{$S R-6$} & 31 & $\begin{array}{c}21,72 \\
a\end{array}$ & & & \\
\hline & & 22,00 & 215,65 & 10 & 2,11 \\
\hline
\end{tabular}


Tabela 11

Massa especifica aparente seca dos Arenitos Caiua

b) Faixa granulomëtrica $21 / 2>\phi>2^{\prime \prime}(6,35>\phi>5,08 \mathrm{~cm})$

\begin{tabular}{|c|c|c|c|c|c|c|}
\hline $\begin{array}{l}\text { SONDAGEM } \\
\text { NOMERO }\end{array}$ & $\begin{array}{l}\text { AMOSTRA } \\
\text { NOMERO }\end{array}$ & $\begin{array}{c}\text { PROFUNDIDADE } \\
(\mathrm{m})\end{array}$ & $\begin{array}{l}\text { COTA } \\
(m)\end{array}$ & EXEMPLARES & $\begin{array}{l}\text { MEDIA } \\
\bar{x}\end{array}$ & $\begin{array}{l}\text { DESVIO } \\
\text { PADRÃO } \sigma\end{array}$ \\
\hline$S R-1$ & 13 & $\begin{array}{r}9,68 \text { a } \\
10,67\end{array}$ & 235,58 & 4 & 1,83 & 0,06 \\
\hline$S R-2$ & 15 & $\begin{array}{l}16,42 \text { a } \\
17,81\end{array}$ & 226,28 & 5 & 1,91 & 1,32 \\
\hline$S R-3$ & 16 & $\begin{array}{l}13,42 \text { a } \\
14,20\end{array}$ & 227,10 & 5 & 1,84 & - \\
\hline I dem & 20 & $\begin{array}{l}32,40 \text { a } \\
36,54\end{array}$ & 208,63 & 5 & 2,19 & 0,11 \\
\hline$S R-4$ & 22 & $\begin{array}{l}17,30 \text { a } \\
18,65\end{array}$ & 223,90 & 4 & 1,74 & 1,52 \\
\hline I dem & 23 & $\begin{array}{l}28 ; 30 \text { a } \\
29,95\end{array}$ & 212,90 & 5 & 1,98 & 1,38 \\
\hline$S R-5$ & 24 & $\begin{array}{l}10,00 \text { a } \\
11,20\end{array}$ & 228,14 & 5 & $\begin{array}{l}\text { As amostras } \\
\text { garam-se t } \\
\text { durante a } s\end{array}$ & $\begin{array}{l}\text { desagre- } \\
\text { otalmente } \\
\text { aturação. }\end{array}$ \\
\hline $\begin{array}{l}\text { Idem } \\
(*)\end{array}$ & 26 & $\begin{array}{l}17,36 \text { a } \\
18,62\end{array}$ & 220,78 & 5 & 1,68 & 0,06 \\
\hline Idem & 28 & $\begin{array}{l}31,88 \text { a } \\
33,00\end{array}$ & 206,26 & 5 & 2,19 & 0,1 \\
\hline$S R-6$ & 29 & $\begin{array}{r}9,00 \text { a } \\
12,00\end{array}$ & 228,37 & 5 & 1,80 & 1,28 \\
\hline Idem & 30 & $\begin{array}{l}19,85 \text { a } \\
21,49\end{array}$ & 217,52 & 5 & \multicolumn{2}{|c|}{$\begin{array}{l}\text { As amostras desagre- } \\
\text { garam-se totalmente } \\
\text { durante a saturação. }\end{array}$} \\
\hline SR-7 & 33 & $\begin{array}{l}10,20 \text { a } \\
11,50\end{array}$ & 226,30 & 5 & \multicolumn{2}{|c|}{$\begin{array}{l}\text { Quatro dos cinco cor } \\
\text { pos de prova desagre } \\
\text { garam-se totalmente } \\
\text { durante a saturação. }\end{array}$} \\
\hline $\begin{array}{l}S R-7 \\
(* * x)\end{array}$ & 35 & $\begin{array}{l}21,60 \text { a } \\
23,15\end{array}$ & 214,90 & 5 & 2,08 & 0,12 \\
\hline I dem & 36 & $\begin{array}{l}29,71 \text { a } \\
31,27\end{array}$ & 206,79 & 5 & 1,99 & 0,067 \\
\hline$S R-8$ & 37 & $\begin{array}{l}14,60 \text { a } \\
15,86\end{array}$ & 227,00 & 5 & 1,90 & 0,027 \\
\hline Idem & 38 & $\begin{array}{l}28,72 \text { a } \\
30,32\end{array}$ & 218,88 & 5 & 2,34 & 1,67 \\
\hline
\end{tabular}

(*) Duas das cinco amostras desintegrarammse totalmente durante a saturação

(**) Um dos corpos de prova desagregou-se totalmente durante a saturação. 


\section{Absorção d'ägua}

Ensaiadas as amostras dos conjuntos 1,2 e 3 .

Tabela 12

Valores da absorção d'ägua nós Arenitos Caiuä

A - Conjunto 1

\begin{tabular}{|c|c|c|c|c|}
\hline Amostra & Proveniência & $\begin{array}{c}\text { Prof. } \\
(\mathrm{m})\end{array}$ & $\begin{array}{c}\text { Alt itude } \\
(\mathrm{m})\end{array}$ & $A_{b}(\%)$ \\
\hline 1 & $S R-15$ & 12,30 & 243,71 & 14,07 \\
\hline 2 & $" 1$ & 33,00 & 223,015 & 11,78 \\
\hline 3 & $" 1$ & 15,50 & 240,515 & 17,36 \\
\hline 4 & 11 & 15,75 & 240,315 & - \\
\hline 5 & $S R-3$ & 9,00 & 232,028 & 15,30 \\
\hline 6 & 11 & 10,50 & 230,528 & - \\
\hline 7 & $" 1$ & 28,70 & 213,328 & 13,30 \\
\hline 8 & 11 & 32,60 & 250,00 & 5,91 \\
\hline 9 & Afloramento & - & 245,00 & 14,8 \\
\hline 10 & $" 1$ & - & 245,00 & 11,78 \\
\hline 11 & $" 1$ & - & 245,00 & 11,54 \\
\hline 12 & $"$ & - & 245,00 & $\begin{array}{l}11,45 \\
\text { Mëdia } \bar{x}=12,93 \\
\text { Desvio } \sigma=1,96 \\
\text { Padrão }\end{array}$ \\
\hline
\end{tabular}

B - Conjunto 2

Tabela 1.3

Valores da absorção d'ägua nos Arenitos Caiuá

a) Amostras provenientes do local 1

\begin{tabular}{lc}
\hline Faixa granulomëtria & $3>\phi>2^{\prime \prime}(7,62>\phi>5,08 \mathrm{~cm})$ \\
\hline Nümero de exemplares & 10 \\
Mëdia $\bar{x}$ & 13,09 \\
Desvio Padrão $\sigma$ & 2,92 \\
\hline
\end{tabular}


b) Amostras provenientes do local 11

Tabela 14

Valores da absorção d'ägua nos Arenitos Caiuã

\begin{tabular}{|c|c|c|c|c|}
\hline Faixas granulomëtricas & $\begin{array}{l}11 / 2 \\
(3,81\end{array}$ & $\begin{array}{l}>\phi>11 \\
>\phi>2,54 \mathrm{~cm})\end{array}$ & $\begin{array}{l}21 / 2 \\
6,35\end{array}$ & $\begin{array}{l}>\phi>2^{\prime \prime} \\
>\phi>5,08 \mathrm{~cm}\end{array}$ \\
\hline Nümeros de exemplares & & 20 & & 30 \\
\hline Mëdia $\bar{x}$ & & 9,417 & & 9,58 \\
\hline Desvio padrão $\sigma$ & & 2,73 & & 0,58 \\
\hline
\end{tabular}

C - Conjunto 3

Ensaios realizados com testemunhos de sondagens rotativas dos locais de amostragem $\| 1 \mathrm{e} V$.

Tabela 15

Valores da absorção d'ägua nos Arenitos Caiuä

a) Faixa granulomëtrica $2>\phi>11 / 2(5,08>\phi>3,81 \mathrm{~cm})$

\begin{tabular}{|c|c|c|c|c|c|c|}
\hline $\begin{array}{l}\text { SONDAGEM } \\
\text { NOMERO }\end{array}$ & $\begin{array}{l}\text { AMOSTRA } \\
\text { NOMERO }\end{array}$ & $\begin{array}{c}\text { PROFUNDI DADE } \\
(\mathrm{m})\end{array}$ & $\begin{array}{l}\text { COTA } \\
(\mathrm{m})\end{array}$ & EXEMPLARES & $\begin{array}{l}\text { MEDIA } \\
\bar{x}\end{array}$ & $\begin{array}{l}\text { DESVIO } \\
\text { PADRÃO } \\
\quad \sigma\end{array}$ \\
\hline$S R-3$ & 18 & $\begin{array}{l}24,88 \text { a } \\
25,04\end{array}$ & 216,15 & 5 & \multicolumn{2}{|c|}{$\begin{array}{l}\text { Amostras desintegra- } \\
\text { ram-se totalmente em } \\
\text { menos de } 2 \text { horas de } \\
\text { saturação }\end{array}$} \\
\hline$S R-3$ & 19 & $\begin{array}{l}27,65 \text { a } \\
27,87\end{array}$ & 213,38 & 4 & 11,95 & 0,71 \\
\hline$S R-5$ & 25 & $\begin{array}{l}11,74 \text { a } \\
11,90\end{array}$ & 226,40 & 3 & \multicolumn{2}{|c|}{$(*)$} \\
\hline$S R-6$ & 31 & $\begin{array}{l}21,72 \text { a } \\
22,00\end{array}$ & 215,65 & 10 & 10,79 & 2,00 \\
\hline
\end{tabular}

(*) Amostras totalmente desagregadas em menos de duas horas de saturação. 
Tabela 16

Valores da absorção d'ägua nos Arenitos Caiuã

b) Faixa granulomëtrica $21 / 2>\phi>2^{11}(6,35>\phi>5,08 \mathrm{~cm})$

\begin{tabular}{|c|c|c|c|c|c|c|}
\hline $\begin{array}{l}\text { SONDAGEM } \\
\text { NOMERO }\end{array}$ & $\begin{array}{l}\text { AMOSTRA } \\
\text { NOMERO }\end{array}$ & $\begin{array}{c}\text { PROFUNDIDADE } \\
(\mathrm{m})\end{array}$ & $\begin{array}{l}\text { COTA } \\
(\mathrm{m})\end{array}$ & EXEMPLARES & $\begin{array}{l}\text { MEDIA } \\
\bar{x}\end{array}$ & $\begin{array}{c}\text { DESVIO } \\
\text { PADRAOO } \\
\sigma\end{array}$ \\
\hline$S R-1$ & 13 & $\begin{array}{r}9,68 \text { a } \\
10,67\end{array}$ & 235,58 & 4 & 12,83 & 1,69 \\
\hline$S R-2$ & 15 & $\begin{array}{l}16,42 \text { a } \\
17,81\end{array}$ & 226,28 & 5 & 11,80 & 1,01 \\
\hline$S R-3$ & 16 & $\begin{array}{l}13,42 \text { a } \\
14,20\end{array}$ & 227,10 & 5 & 14,57 & 0,77 \\
\hline Idem & 20 & $\begin{array}{l}32,40 \text { a } \\
34,54\end{array}$ & 208,63 & 5 & 6,94 & 2,21 \\
\hline$S R-4$ & 22 & $\begin{array}{l}17,30 \text { a } \\
18,65\end{array}$ & 223,90 & 4 & 15,56 & 4,67 \\
\hline Idem & 23 & $\begin{array}{l}28,30 \text { a } \\
29,95\end{array}$ & 212,90 & 5 & 10,74 & 1,18 \\
\hline$S R-5$ & 24 & $\begin{array}{l}10,00 \text { a } \\
10,20\end{array}$ & 228,14 & 5 & \multicolumn{2}{|c|}{ (1) } \\
\hline $\begin{array}{l}\text { Idem } \\
\text { (2) }\end{array}$ & 26 & $\begin{array}{l}17,36 \text { a } \\
18,62\end{array}$ & 220,78 & 5 & 20,46 & 2,87 \\
\hline Idem & 28 & $\begin{array}{l}31,88 \text { a } \\
33,00\end{array}$ & 206,26 & 5 & 7,47 & 1,79 \\
\hline$S R-6$ & 29 & $\begin{array}{r}9,00 \text { a } \\
12,00\end{array}$ & 228,37 & 5 & 14,78 & 0,19 \\
\hline Idem & 30 & $\begin{array}{l}19,85 \text { a } \\
21,49\end{array}$ & 217,52 & 5 & \multicolumn{2}{|c|}{ (1) } \\
\hline$S R-7$ & 33 & $\begin{array}{l}10,20 \text { a } \\
11,50\end{array}$ & 226,30 & 5 & \multicolumn{2}{|c|}{ (3) } \\
\hline $\begin{array}{l}\text { Idem } \\
(4)\end{array}$ & 35 & $\begin{array}{l}21,60 \text { a } \\
23,15\end{array}$ & 214,90 & 5 & 9,70 & 2,87 \\
\hline Idem & 36 & $\begin{array}{l}29,71 \text { a } \\
31,27\end{array}$ & 206,70 & 5 & 11,69 & 2,14 \\
\hline$S R-8$ & 37 & $\begin{array}{l}14,60 \text { a } \\
15,86\end{array}$ & 227,00 & 5 & 12,1 & 1,06 \\
\hline Idem & 38 & $\begin{array}{l}28,72 \text { a } \\
30,32\end{array}$ & 218,88 & 5 & 5,11 & 0,85 \\
\hline
\end{tabular}

(1) As amostras desagregaram-se totalmente durante a saturação.

(2) Duas das cinco amostras desagregaram-se totalmente durante a saturação.

(3) Quatro das cinco amostras desagregaram-se totalmente durante a saturação.

(4) Um dos cinco corpos de prova desagregrou-se totalmente durante a saturação. 


\section{Poros idade aparente}

As amostras ensaiadas pertenciam aos Conjuntos 1,2 e 3 . A - Conjunto 1

Tabela 17

Valores da porosidade aparente dos Arenitos Caiuá

\begin{tabular}{|c|c|c|c|c|}
\hline AMOSTRA & PROVENIENCIA & $\begin{array}{l}\text { PROF, } \\
(\mathrm{m})\end{array}$ & $\begin{array}{l}\text { ALTI T TUDE } \\
(\mathrm{m})\end{array}$ & $P_{a}(\%)$ \\
\hline 1 & $S R-15$ & 12,30 & 243,71 & 23,87 \\
\hline 2 & 11 & 33,00 & 223,015 & 22,00 \\
\hline 3 & 11 & 15,50 & 240,515 & 30,24 \\
\hline 4 & 11 & 15,75 & 240,315 & - \\
\hline 5 & $S R-3$ & 9,00 & 232,028 & 27,46 \\
\hline 6 & 11 & 10,50 & 230,528 & - \\
\hline 7 & $" 1$ & 28,70 & 213,328 & 25,32 \\
\hline 8 & 11 & 32,60 & 208,430 & 11,94 \\
\hline 9 & Af loramento & - & 250,00 & 25,8 \\
\hline 10 & 11 & - & 245,00 & 21,77 \\
\hline 11 & $" 1$ & - & 245,00 & 21,63 \\
\hline \multirow[t]{3}{*}{12} & $" 1$ & - & 245,00 & 21,06 \\
\hline & & & & Mëdia $\bar{x}=23,10$ \\
\hline & & & & $\begin{array}{l}\text { Desvio } \\
\text { Padrão }\end{array}$ \\
\hline
\end{tabular}


B - Conjunto 2

a) Amostras provenientes do local 1.

Tabela 18

Valores da porosidade aparente dos Arenitos Caiuá

\begin{tabular}{lc}
\hline Faixa granulométrica & $3>\phi>2 " 1(7,62>\phi>5,08 \mathrm{~cm})$ \\
\hline Nümero de exemplares & 10 \\
Mëdia $\bar{x}$ & 23,17 \\
Desvio padrão $\sigma$ & 5,12 \\
\hline
\end{tabular}

b) Amostras provenientes do local 11.

Tabela 19

Valores da porosidade aparente dos Arenitos Caiuá

\begin{tabular}{lcc}
\hline Faixas granulomëtricas & $\begin{array}{c}11 / 2>\phi>11 \\
(3,81>\phi>2,54 \mathrm{~cm})\end{array}$ & $\begin{array}{c}21 / 2>\phi>2^{\prime \prime} \\
(6,35>\phi>5,08 \mathrm{~cm})\end{array}$ \\
\hline Nümeros de exemplares & 20 & 30 \\
Mëdia $\bar{x}$ & 18,92 & 28,9 \\
Desvio padrão $\sigma$ & 4,83 & 1,15 \\
\hline
\end{tabular}


C - Conjunto 3

Ensaios realizados com testemunhos de sondagens rotativas, dos locais 111 e V.

Tabela 20

Valores da porosidade aparente dos Arenitos Caiuá

a) Faixa granulomëtrica $2>\phi>11 / 2(5,08>\phi>3,81 \mathrm{~cm})$

\begin{tabular}{|c|c|c|c|c|c|c|}
\hline $\begin{array}{l}\text { SONDAGEM } \\
\text { NOMECRO }\end{array}$ & $\begin{array}{l}\text { AMOSTRA } \\
\text { NOMERO }\end{array}$ & $\begin{array}{c}\text { PROFUND IDADE } \\
(\mathrm{m})\end{array}$ & $\begin{array}{l}\text { COTA } \\
(\mathrm{m})\end{array}$ & EXEMPLARES & $\begin{array}{l}\text { MEDIA } \\
\bar{x}\end{array}$ & $\begin{array}{c}\text { DESVIO } \\
\text { PADRÃO } \\
\sigma\end{array}$ \\
\hline$S R-3$ & 18 & $\begin{array}{l}24,88 \text { a } \\
25,04\end{array}$ & 216,15 & 5 & ( & \\
\hline Idem & 19 & $\begin{array}{l}27,65 \text { a } \\
27,87\end{array}$ & 213,38 & 4 & 25,63 & 1,45 \\
\hline$S R-5$ & 25 & $\begin{array}{l}11,74 \text { a } \\
11,90\end{array}$ & 226,40 & 3 & & \\
\hline$S R-6$ & 31 & $\begin{array}{l}21,72 \text { a } \\
22,00\end{array}$ & 215,65 & 10 & 22,10 & 3,10 \\
\hline
\end{tabular}

(1) Amostras totalmente desagregadas em menos de duas horas de saturação. 
Tabela 21

Valores da porosidade aparente dos Arenitos Caiuä

b) Faixa granulométrica $21 / 2>\phi>2^{\prime \prime}(6,35>\phi>5,08 \mathrm{~cm})$

\begin{tabular}{|c|c|c|c|c|c|c|}
\hline $\begin{array}{l}\text { SONDAGEM } \\
\text { NOMERO }\end{array}$ & $\begin{array}{l}\text { AMOSTRA } \\
\text { NOMERO }\end{array}$ & $\begin{array}{c}\text { PROFUND I DADE } \\
(\mathrm{m})\end{array}$ & $\begin{array}{l}\text { COTA } \\
(\mathrm{m})\end{array}$ & EXEMPLARES & $\begin{array}{l}\text { MEDIA } \\
\bar{x}\end{array}$ & $\begin{array}{c}\text { DESVIO } \\
\text { PADRÃO } \\
\sigma\end{array}$ \\
\hline$S R-1$ & 13 & $\begin{array}{r}9,68 \text { a } \\
10,67\end{array}$ & 235,58 & 4 & 23,48 & 1,76 \\
\hline$S R-2$ & 15 & $\begin{array}{l}16,42 \text { a } \\
17,81\end{array}$ & 226,28 & 5 & 22,51 & 1,53 \\
\hline$S R-3$ & 16 & $\begin{array}{l}13,42 \text { a } \\
14,20\end{array}$ & 227,10 & 5 & 26,82 & 1,29 \\
\hline I dem & 20 & $\begin{array}{l}32,40 a \\
34,54\end{array}$ & 208,53 & 5 & 15,22 & 3,88 \\
\hline$S R-4$ & 22 & $\begin{array}{l}17,30 \text { a } \\
18,65\end{array}$ & 223,90 & 4 & 26,53 & 5,95 \\
\hline I dem & 23 & $\begin{array}{l}28,30 \text { a } \\
29,95\end{array}$ & 212,90 & 5 & 21,25 & 1,91 \\
\hline$S R-5$ & 24 & $\begin{array}{l}10,00 \text { a. } \\
10,20\end{array}$ & 228,14 & 5 & & 1) \\
\hline $\begin{array}{c}S R-5 \\
(2)\end{array}$ & 26 & $\begin{array}{l}17,36 \text { a } \\
18,62\end{array}$ & 220,78 & 5 & 34,23 & 3,35 \\
\hline$S R-5$ & 28 & $\begin{array}{l}31,88 \text { a } \\
33,00\end{array}$ & 220,78 & 5 & 16,24 & 3,30 \\
\hline$S R-6$ & 29 & $\begin{array}{r}9,00 \\
12,00\end{array}$ & 228,37 & 5 & 26,68 & 0,26 \\
\hline Idem & 30 & $\begin{array}{l}19,85 \text { a } \\
21,49\end{array}$ & 217,52 & 5 & & \\
\hline$S R-7$ & 33 & $\begin{array}{l}10,20 \mathrm{a} \\
11,50\end{array}$ & 226,30 & 5 & & ) \\
\hline I dem & 35 & $\begin{array}{l}21,60 \text { a } \\
23,15\end{array}$ & 214,90 & 5 & 19,98 & 4,84 \\
\hline Idem & 36 & $\begin{array}{l}29,71 \text { a } \\
31,27\end{array}$ & 206,70 & 5 & 23,17 & 3,30 \\
\hline$S R-8$ & 37 & $\begin{array}{l}14,60 \text { a } \\
14,86\end{array}$ & 227,00 & 5 & 23,02 & 1,13 \\
\hline Idem & 38 & $\begin{array}{l}28,72 \text { a } \\
30,32\end{array}$ & 218,88 & 5 & 11,96 & 1,91 \\
\hline
\end{tabular}

(1) As amostras desagregaram-se totalmente durante a saturação

(2) Duas das cinco amostras desagregaram-se totalmente durante a saturação

(3) Quatro das cinco amostras desagregaram-se totalmente durante a saturação 


\section{Porosidade real}

Foram ensaiadas amostras do Conjunto 1, conforme a tabela 22.

\section{Tabela 22}

Porosidade real dos Arenitos Caiuá

\begin{tabular}{cc}
\hline AMOSTRA & $P_{r}(\%)$ \\
\hline 1 & 36,37 \\
\hline 3 NERO & 35,31 \\
4 & 34,56 \\
5 & - \\
6 & 32,78 \\
7 & - \\
8 & 27,75 \\
9 & 23,10 \\
10 & 34,68 \\
11 & 30,35 \\
12 & 29,08 \\
& 30,64 \\
& Média $=31,46$ \\
& Padräo $\sigma=4,11$ \\
\hline
\end{tabular}


Percentagem de saturação dos vazios

As amostras ensaiadas foram as do Conjunto 1 , conforme a tabela 23.

Tabela 23

Porosidade real dos Arenitos Caiuá

\begin{tabular}{cc} 
AMOSTRA & SOMERO \\
\hline 1 & 65,63 \\
2 & 61,18 \\
3 & 87,49 \\
4 & - \\
5 & 83,76 \\
6 & - \\
7 & 91,24 \\
9 & 51,68 \\
10 & 74,39 \\
11 & 71,74 \\
12 & 74,38 \\
& 68,73 \\
& Mesdia $\bar{x}=73,02$ \\
& Dadrão $\sigma=12,16$ \\
\hline
\end{tabular}

Foram examinados os resultados das propriedades físicas dos arenitos ensaiados, à luz de rudimentos de Estatística. Calculou-se, como é possivel ver-se nas tabelas 5 a 23 , as mëdias e os desvios padrões dos valores de ensaios. Foram considerados, em determinados ensaios, exemplares constituintes de uma amostra populacional na vertical, ou seja, a värias profundidades, como tambëm conjuntos de amostras de uma ünica profundidade, em outros ensaios.

Determinam-se assim:

a) A mëdia aritmëtica ou a mẻdia da distribuição;

b) 0 desvio padrão. Como se sabe, das medidas de dispersão da mê 
dia em Estatística, ê multo usada a Variância, que è a média dos quadrados dos desvios dos valores da variâvel, em relação à sua mêdia. 0 desvio padrão ê a raiz quadrada da variância.

Verifica-se, examinando-se as tabelas de nûmeros 5 a 23 , que algumas propriedades físicas apresentam altos valores do desvio padrão, enquanto para outros valores pouco significativos.

Pode-se sugerir que este fato seria devido a:

1) Imprecisões nas obtenções dos valores (pesagem, por exemplo).

2) Tempo insuficiente para se atingir condições ideais de ensaio (saturações e secagens incompletas).

3) Grande variação em certas propriedades consideradas, mesmo em fragmentos adjacentes.

4) Nümero de indivíduos de uma população ensaiados. Em algumas tabelas, nota-se altos valores do desvio padrão quando os exemplares ensaiados são muitos (por exemplo, Tabela 9). Toda via verificamse que para outras propriedades ocorre justamente o conträrio, ou seja, ensaios com poucos exemplares é que fornecem altos valores do desvio padrão (Tabela 16).

5) Variações consideräveis em função da profundidade, para algumas propriedades. Isto se nota na porosidade aparente, porosi dade real e porcentagem de saturação dos vazios, mas não na densidade dos grãos e massa específica aparente seca.

Conclui-se que algumas propriedades devem variar aleatoriamente e outras não, porēm faz-se necessärlo um estudo estatístico como anälise de regressão, para que se possa compreender com precisão, o porque dessas variações.

$\mathrm{Na}$ tabela 24 , que se seque, são relacionadas as propriedades físicas dos Arenitos Caiuá, a partir das tabelas 6 a 23 , e do arenito Botuca tu estudadas por Ruiz (1966). 
Tabela 24

Valores comparativos das propriedades físicas dos

Arenitos Caluä e Botucatu

Arenito Caiuä (*) Arenito Botucatu

\begin{tabular}{lcc}
\hline Densidade dos grãos - $\mathrm{s}\left(\mathrm{g} / \mathrm{cm}^{3}\right)$ & 2,653 & 2,44 \\
$\begin{array}{l}\text { Massa específica aparente seca } \\
\text { as }\left(\mathrm{g} / \mathrm{cm}^{3}\right)\end{array}$ & 1,96 & 2,32 \\
Absorção d'ägua - Ab $(\%)$ & 11,78 & 1,2 \\
Porosidade aparente $-P_{a}(\%)$ & 22,99 & 2,8 \\
Porosidade real $-P_{r}(\%)$ & 31,46 & 5,0 \\
Percentagem de saturação dos vazios & & \\
S (\%) & 73,02 & 56,0
\end{tabular}

(*) Valores mëdios.

O arenito Botucatu em questão ê segundo Ruiz (1966) uma rocha vermelho-claro, de granulação fina, textura clästica e levemente estratifi cado, composta essencialmente por grãos de quartzo cimentados por material silicoso. o grau de cimentação ë variävel, e quando os grãos são bem cimen tados, a rocha rompe-se segundo superfícies irregulares em fragmentos de arestas cortantes e bordos resistentes. Compõe-se tal arenito, de grãos de quartzo bem arredondados, com elevado grau de esfericidade, cimentados por matëria silicosa secundäria. Presentes subsidiariamente, feldspatos, em ge ral microclinio e plagiocläsio (com sinais de alteração), turmalina e mine rais opacos.

Na tabela 24 são evidentes as diferenças entre os Arenitos Caiuä e Botucatu. No que se refere à densidade dos grãos, conclui-se que a contribuição dos minerais pesados para os valores deste parâmetro ë significa tiva. Na tabela 25, vêem-se as incidências de minerais pesados em algumas amostras do Arenito Caiuä: 
Minerais pesados (em \%) no Arenito Caiuä

\begin{tabular}{|c|c|c|c|c|c|c|c|c|}
\hline $\begin{array}{l}\text { Amostra } \\
\text { Dumerolhes } \\
\text { das amostras } \\
\text { e minerais } \\
\text { pesados }\end{array}$ & 1 & 4 & 6 & 7 & 8 & 10 & 11 & 12 \\
\hline Proveniência & $S R-15$ & $S R-15$ & $S R-3$ & $S R-3$ & $S R-3$ & $\begin{array}{l}\text { Escavaçao } \\
(\text { local } 11)\end{array}$ & $\begin{array}{l}\text { Escavação } \\
(\text { local } \mid 1)\end{array}$ & $\begin{array}{l}\text { Escavaçao } \\
(\text { local II) }\end{array}$ \\
\hline Profundidade $(\mathrm{m})$ & 12,30 & 15,75 & 10,50 & 28,70 & 32,60 & - & - & - \\
\hline Aititude $(m)$ & 243,71 & 240,315 & 230,528 & 213,328 & 208,43 & 245,00 & 245,00 & 245,00 \\
\hline Magnetita e Ilmenita & 59 & 74 & 75 & 58 & 60 & 81 & 82 & 87 \\
\hline Leucoxênio & 23 & 14 & 13 & 27 & 23 & 10 & 11 & 4 \\
\hline Limonita & 7 & 4 & 3 & 3 & 12 & - & 3 & 2 \\
\hline Pirita & 3 & 4 & 4 & 4 & 2 & - & 2 & 2 \\
\hline Hematita & 2 & 4 & - & - & - & - & - & - \\
\hline Turmal ina & - & raro & 2 & - & - & 5 & raro & 2 \\
\hline Estaurolita & 2 & - & raro & - & raro & 2 & 2 & 3 \\
\hline Epídoto & raro & - & 3 & - & raro & raro & raro & raro \\
\hline Granada & - & - & - & 4 & 3 & - & raro & - \\
\hline Ruti lo & raro & - & - & 4 & raro & 2 & - & raro \\
\hline Zi rcão & raro & raro & raro & - & - & raro & - & raro \\
\hline
\end{tabular}


Nota-se que a magnetita ocorre em grande quantidade e sobretudo nos exemplares provenientes da escavação $16 \mathrm{~km}$ a montante de Porto Rosana, no Rio Paraná (local 11).

Quanto à Massa Específica Aparente Seca, vêrse que são maiores os valores para o Arenito Botucatu. Pode-se supor que isto se dã em função da maior Porosidade dos Arenitos Caiuä, relativamente aos Arenitos Botucatu, de forma que de dois fragmentos com volumes idênticos dessas rochas, pesaria menos o referente ao Caiuá.

A propôsito são flagrantes as diferenças entre as porosidades real e aparente dos dois materiais e os parâmetros correlacionâveis às mesmas, como a absorção d'ãgua e a porcentagem de saturação dos vazios, que apresentam valores muito maiores para os Arenitos Caiuä.

\section{Ensaios de durabilidade}

\section{Ciclagem natural}

Tiveram por objetivo a verificação das variações da resistência dos arenitos Caiuä, quando submetidos ao pröprio processo normal de desagregação. Foram ensaladas frações de rocha, correspondentes a diversas gra nulometria determinadas após lavagem completa e secagem em estufa à temperatura de $100 \pm 5^{\circ} \mathrm{C}$, até peso constante, bem como blocos de grandes tama nhos, conforme se verifica nas tabelas nümeros 26 e 27 , e nas figuras nüme $\operatorname{ros} 14,15$ e 16 .

O exame quantitativo foi feito comparando-se a granulometria ini cial com a prova granulometria determinada apös secagem de amostra em estu fa à temperatura de $100 \pm 5^{\circ} \mathrm{C}$, atë peso constante.

0 exame qualitativo constou de observações, para cada fração, de possiveis trincas, fragmentação, desintegração e desprendimento de lascas, sendo tal exame especifico para partículas maiores que $3 / 8^{\prime \prime}$.

\section{Ciclagem ace lerada (ägua-estufa)}

Cada amostra foi submetida a ciclos alternados de imersão em ä- 
gua e secagem em estufa a $100 \pm 5^{\circ} \mathrm{C}$. A duração dos cíclos foi variável bem como a duração total dos ensaios, conforme as tabelas nümeros 28 a 37 . Apös a retirada das amostras da estufa, elas foram submetidas a um resfria mento natural de 1 hora, antes de nova imersão. Ao final de cada sërie de ciclos as amostras foram submetidas a exames quantitativos e qualitativos obedecendo a idêntico procedimento que para a ciclagem natural. Os gräficos referentes a esses ensaios são representados pelas figuras nümeros 17 a 26 .

Nas tabelas citadas, que resumem os dados dos ensaios de ciclagem, as colunas correspondem ao seguinte:

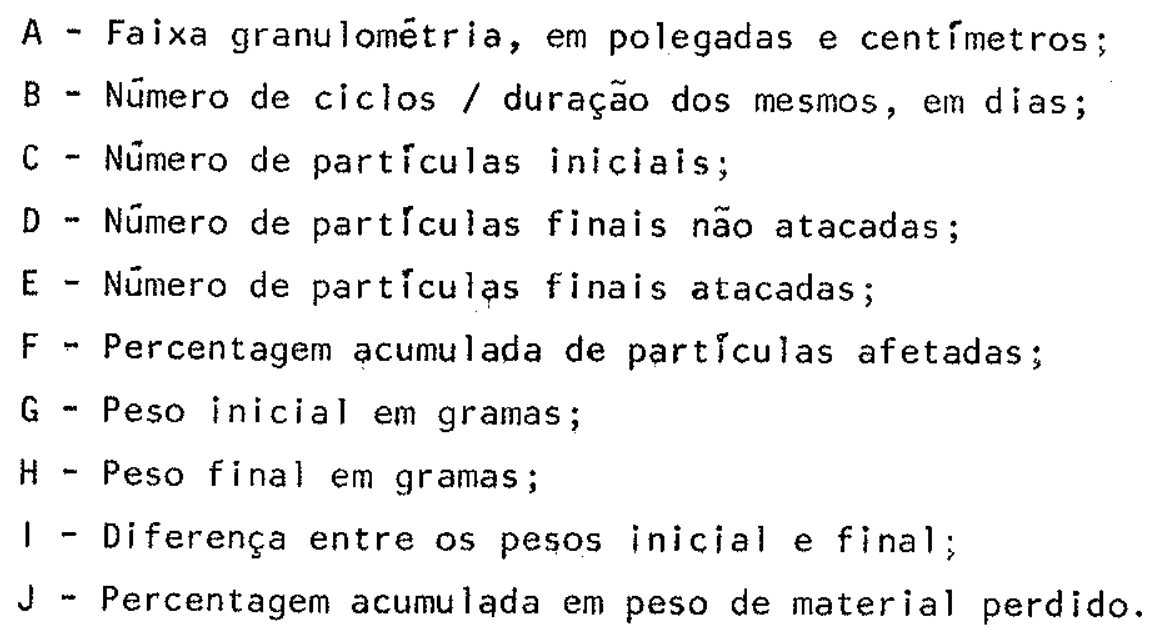


Tabela 26

Ciclagem natural com os Arenitos Caiuä

Proveniência das amostras: local 11

Tipo de rocha: Arenito Caiuã limonítico

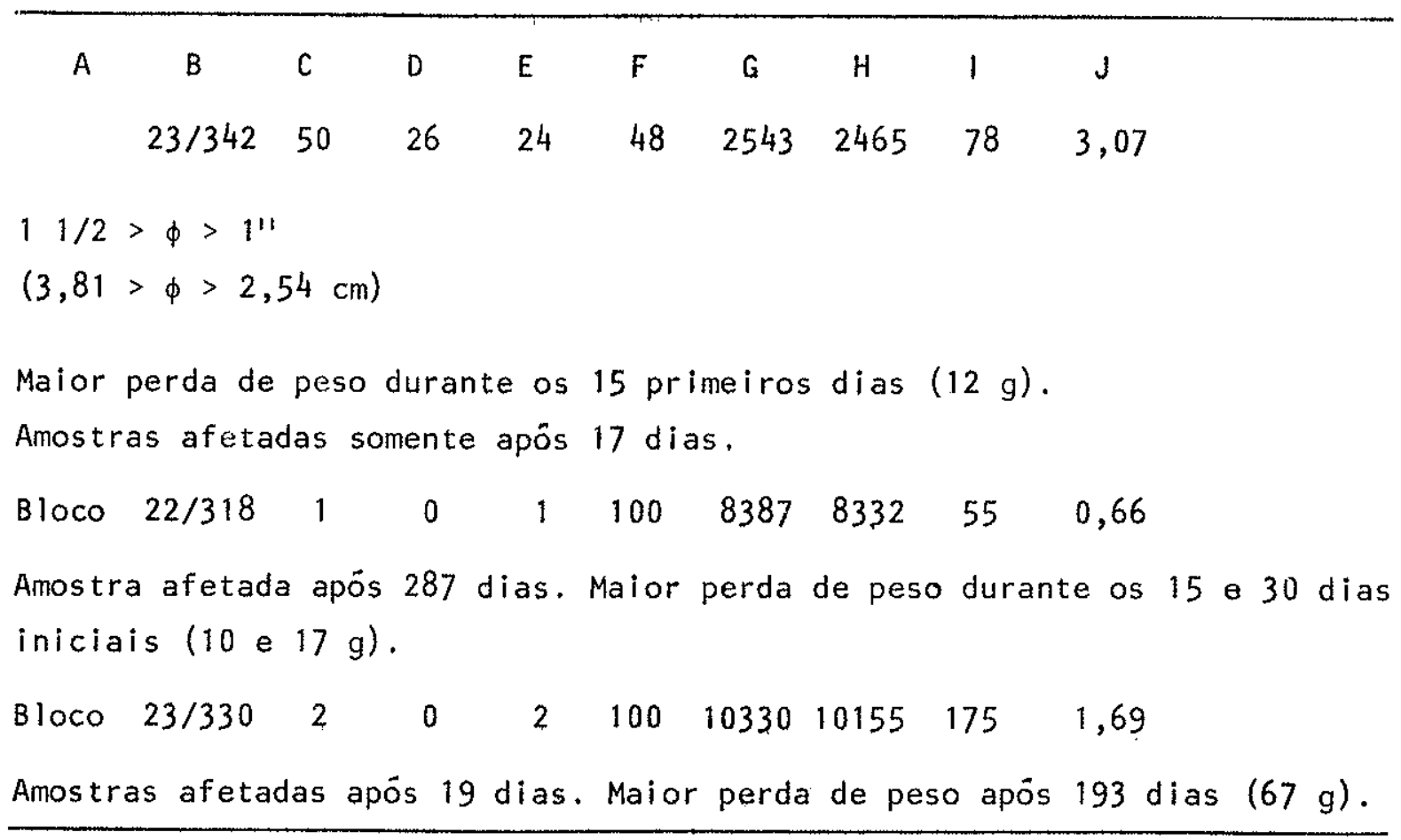

Tabela 27

Ciclagem natural com os Arenitos Caiuä

Proveniência das amostras: local I

Tipo de rocha: Arenito Caiuä limonitico

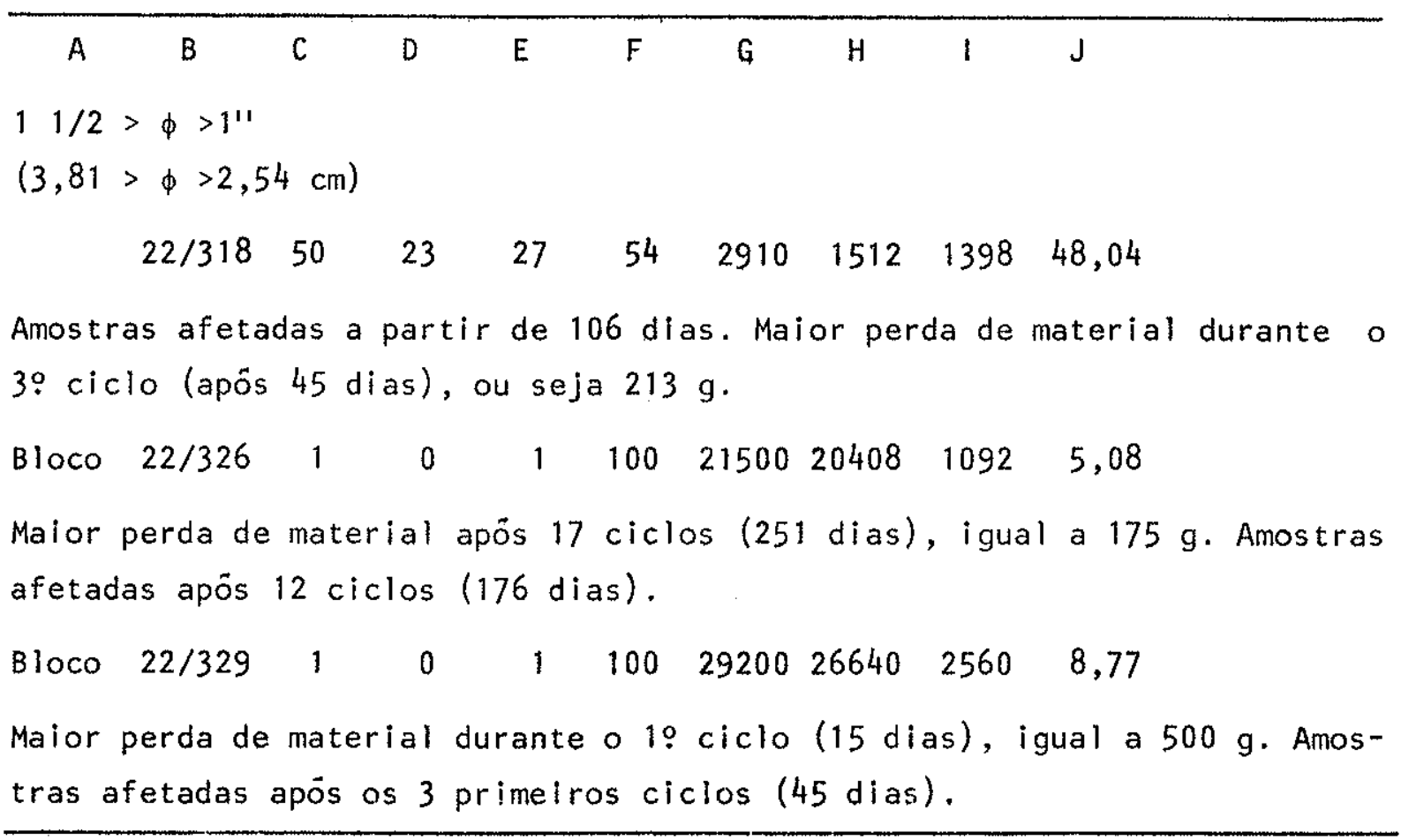


Tabe la 28

Ciclagem ägua-estufa com os Arenitos Caiuã

Proveniência das amostras: local il

Tipo de rocha: arenito Caiuá limonítico

$\begin{array}{cccccccccc}A & B & C & D & \text { E } & \text { F } & \text { G } & H & 1 & \text { J } \\ 3>\phi>2^{\prime \prime} & 72 / 116 & 5 & 2 & 3 & 60 & 2046 & 2013 & 33 & 1,61 \\ (7,62>\phi>5,08 \mathrm{~cm}) & & & & & & & & & \end{array}$

Amostras afetadas apös 97 dias. Maior perda de material (13 g) apös dias do início.

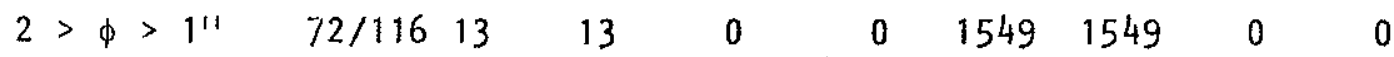

$(5,08>\phi>2,54 \mathrm{~cm})$

Amostras não afetadas. Material possivelmente laterizado.

$\begin{array}{llllllllll}1>\phi>1 / 2^{\prime \prime} & 72 / 116 & 80 & 72 & 8 & 10 & 1019 & 983 & 36 & 3,53\end{array}$

$(2,54>\phi>1,17 \mathrm{~cm})$

Amostras afetadas após 77 dias. Malor perda de material (19 g) após 20 dias.
$1 / 2>\phi>3 / 8^{\prime \prime} 72 / 116-$
$512 \quad 278 \quad 234 \quad 45,70$
$(1,27>\phi>0,95 \mathrm{~cm})$

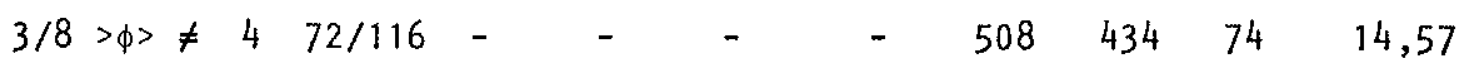
$(0,95>\phi>0,47 \mathrm{~cm})$

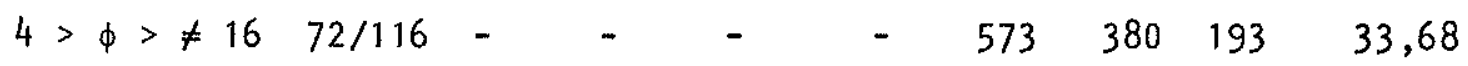
$(0,47>\phi>0,12 \mathrm{~cm})$

Grandes perdas de peso em virtude das pequenas dimensões das amostras.

$\begin{array}{lllllllllll}3>\phi>2 & 1 / 2^{\prime \prime} & 72 / 118 & 8 & 0 & 8 & 100 & 3926 & 3836 & 90 & 2,29\end{array}$

$(7,62>\phi>6,35 \mathrm{~cm})$

Amostras afetadas apös 12 ciclos inicials. Maior perda de material $(40 \mathrm{~g})$ apös 93 dias.

$\begin{array}{lllllllllll}21 / 2>\phi>2^{\prime \prime} & 76 / 118 & 18 & 2 & 16 & 88,89 & 4027 & 3779 & 248 & 6,16\end{array}$

$(6,35>\phi>5,08 \mathrm{~cm})$

Amostras afetadas desde os 12 primeiros ciclos. Maior perda de material (191 g) após 93 dias.

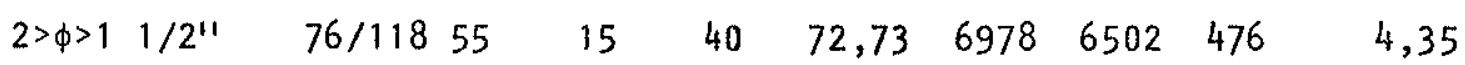

$(5,08>\phi>3,81 \mathrm{~cm})$

Amostras afetadas desde o início $(12$ ciclos $)$. Maior perda de material apôs 93 dias $(149 \mathrm{~g})$.

$\begin{array}{llllllllll}11 / 2>\phi>1^{11} & 76 / 118 & 37 & 16 & 21 & 56,76 & 2009 & 1904 & 105 & 5,23\end{array}$

$(3,81>\phi>2,54 \mathrm{~cm})$

Amostras afetadas desde o início. Maior perda de material $(62 \mathrm{~g})$ apōs 58 dias

$\begin{array}{llllllllll}1>\phi>3 / 8^{\prime \prime} & 76 / 118 & 137 & 68 & 69 & 50,36 & 1966 & 1874 & 92 & 4,68\end{array}$

$(2,54>\phi>0,95 \mathrm{~cm})$

Amostras afetadas desde o início. Maior perda de peso apôs 19 e 93 dias $(17 \mathrm{~g})$. 
Tabela 29

Ciclagem ägua-estufa com os Arenitos Caiuä

Proveniências das amostras: local 1 - Arenito Caiuá limonítico.

\begin{tabular}{ccccccccccc}
\hline$A$ & $B$ & $C$ & $D$ & $E$ & $F$ & $G$ & $H$ & 1 & $J$ \\
$3>\phi>2^{\prime \prime}$ & $72 / 116$ & 5 & 0 & 5 & 100 & 2212 & 462 & 1750 & 79,11 \\
$(7,62>\phi>5,08 \mathrm{~cm})$ & & & & & & & & &
\end{tabular}

Maior perda de peso apös 20 e 41 dias do início, respectivamente 612 e 667 g. Amostras afetadas durante os 20 dias iniciais.
$\begin{array}{llllllllll}2>\phi>1 " & 72 / 116 & 13 & 2 & 11 & 84,62 & 1510 & 132 & 1378 & 91,26\end{array}$
$(5,08>\phi>2,54 \mathrm{~cm})$

Maior perda durante os 20 e 41 dias iniciais $(875$ e $293 \mathrm{~g}$, respectivamente). Amostras afetadas desde o início, ou seja, durante os 20 primeiros dias do ensaio.

$\begin{array}{llllllllllll}1>\phi>1 / 2^{\prime \prime} & 72 / 116 & - & - & - & - & 972 & 99 & 873 & 89,81 \\ (2,54>\phi>1,27 \mathrm{~cm}) & & & & & & & & & & \end{array}$

Não foram feitas observações qualitatlvas. Maior perda de material durante os 20 e 41 primeiros dias, correspondendo a 653 e $99 \mathrm{~g}$.

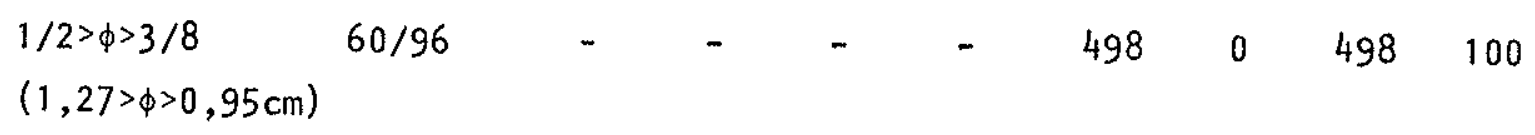

Não foram feitos estudos qualitativos devido às pequenas dimensões das amostras. Maior perda de peso durante os 20 primeiros dias do ensaio.

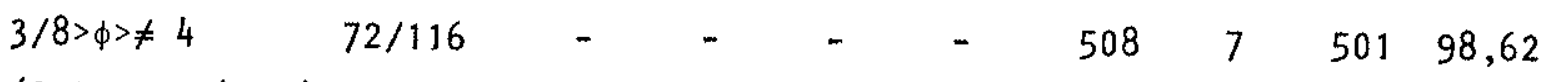 $(0,95>\phi>0,47 \mathrm{~cm})$

Sem exame quantitativo devido às pequenas dimensões das amostras. Maior perda de peso durante os 20 primeiros dias de ensaio.

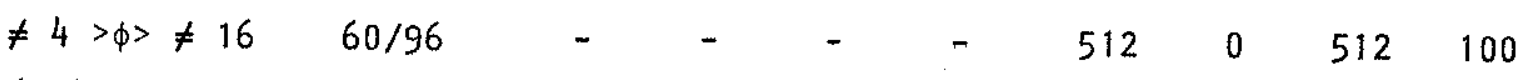
$(0,47>\phi>0,12 \mathrm{~cm})$

Sem exame qualitativo devido às pequenạs dimensões das amostras. Maior perda de peso durante os 20 primeiros dias de teste $(395 \mathrm{~g})$. 
Tabela 30

Ciclagem ägua-estufa com os Arenitos Caiuä

$S R-1$

Profundidade (m)

Altitude ( $m$ )

9,68 a 10,67 235,58 a 234,59

$\begin{array}{cccccccccc}A & B & C & D & E & F & G & H & 1 & J \\ 2>\phi>11 & 60 / 95 & 25 & 0 & 25 & 100 & 1435,10 & 713,20 & 721,90 & 50,30 \\ (5,08>\phi>2,54 \mathrm{~cm}) & & & & & & & & & \end{array}$

Amostras afetadas a partir dos 12 ciclos (19 dias). Maior perda de peso tambëm nesse período, igual a $251 \mathrm{~g}$.

Tabela 31

Ciclagem ảguamestufa com os Arenitos Caiuä

$S R-2$

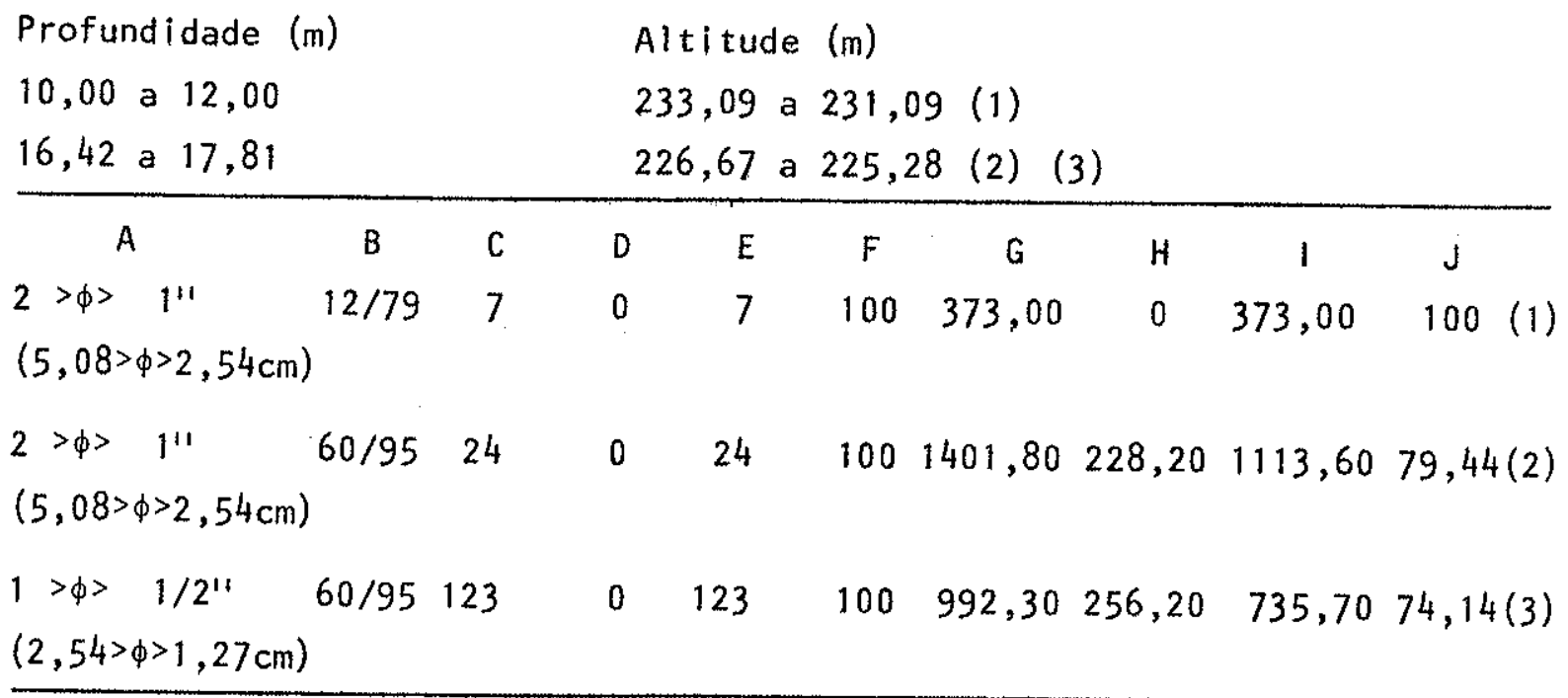


Tabela 32

Ciclagem águarestufa com os Arenitos Caiuã

$S R-3$

Profundidades

13,42 a 14,20

227,60 a 226,82 (1) (2)

22,70 a 24,43

218,32 a 216,59

(3) $(4)$

32,40 a 34,54

208,62 a 206,48

(8)

(9) $(10)(11)$

\begin{tabular}{cccccccccc}
\hline$A$ & $B$ & $C$ & $D$ & $E$ & $F$ & $G$ & $H$ & 1 & $J$ \\
$3>\phi>2^{\prime \prime}$ & $78 / 124$ & 6 & 0 & 6 & 100 & 2026,30 & 1554,80 & 471,50 & $23,27(1)$ \\
$(7,62>\phi>5,08 \mathrm{~cm})$ & & & & & & & &
\end{tabular}

Amostras afetadas após os 12 primeiros ciclos. Maior perda de peso após os $78 \mathrm{ciclos}(124$ dias), igual a $172,70 \mathrm{~g}$.

$1>\phi>1 / 2^{\prime 1} \quad 78 / 124 \quad 122 \quad 0 \quad 122 \quad 100 \quad 839,40 \quad 212,30 \quad 627,10 \quad 74,71(2)$ $(1,27>\phi>0,95 \mathrm{~cm})$

Amostras afetadas apôs os 12 primeiros ciclos. Maior perda de peso $(186,60 \mathrm{~g})$ tambëm nesse período).

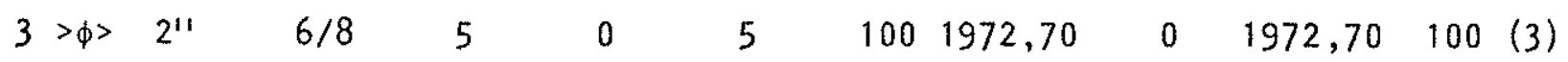
$(7,62>\phi>5,08 \mathrm{~cm})$

Durante as 13 primelras horas de imersão, observou-se perda de $1692,50 \mathrm{~g}$.

$2>\phi>\quad 1^{\prime \prime} \quad 78 / 124 \quad 31 \quad 0 \quad 31 \quad 100 \quad 1497,50 \quad 214,30 \quad 1283,20 \quad 85,59(4)$ $(5,08>\phi>2,54 \mathrm{~cm})$

Amostras afetadas desde os 12 primeiros ciclos (19 dias). Maior perda de peso tambëm nesse período, equivalente a $1075,70 \mathrm{~g}$.

$\begin{array}{llllllllllll}1>\phi> & 1 / 2^{\prime \prime} & 36 / 57 & 135 & 0 & 135 & 100 & 1007,10 & 0,00 & 1007,10 & 100 & (5)\end{array}$ $(2,54>\phi>1,27 \mathrm{~cm})$

Amostras afetadas desde os 6 primeiros ciclos ( 8 dias). Maior perda de peso $(982,10 \mathrm{~g})$ também neste período.

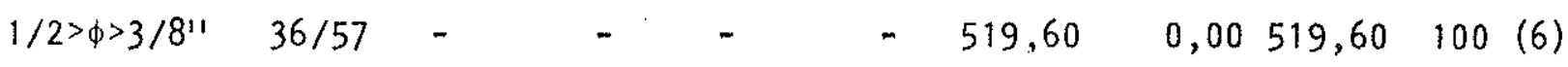
$(1,27>\phi>0,95 \mathrm{~cm})$

Amostras afetadas desde os 6 primeiros ciclos ( 8 dias). Maior perda de peso $(515,20 \mathrm{~g})$ tambëm nesse período. 
Tabela 32 - folha 2

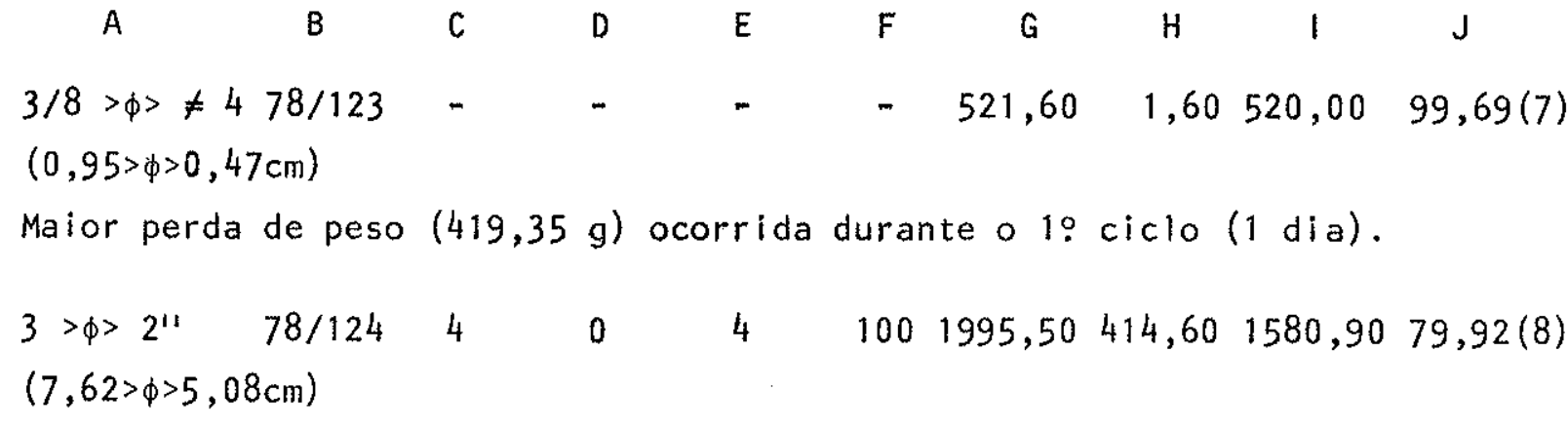

Amostras afetadas desde os 12 primeiros ciclos (19 dias). Maior perda de peso tambëm neste periodo, equivalente a $1396,50 \mathrm{~g}$.

$2>\phi>1^{11} \quad 78 / 124 \quad 22 \quad 0 \quad 22 \quad 100 \quad 1499,50 \quad 319,90 \quad 1359,60 \quad 90,67(9)$ $(5,08>\phi>2,54 \mathrm{~cm})$

Amostras afetadas desde o iníclo, ou seja nos $19 \mathrm{~s}$ ciclos (19 dias). Maior perda de peso $(659,60 \mathrm{~g})$ também nesse período.

$1>\phi>1 / 2^{11} \quad 78 / 124 \quad 90 \quad 0 \quad 90 \quad 100 \quad 1024,40 \quad 152,40 \quad 872,00 \quad 85,12(10)$ $(2,54>\phi>1,27 \mathrm{~cm})$

Amostras afetadas desde o início (12 ciclos, 19 dias). Maior perda de peso $(437,20 \mathrm{~g})$ tambëm nesse período.

$1 / 2>\phi>3 / 8^{\prime 1} 78 / 124 \quad-\quad \quad-\quad \quad-\quad 534,80 \quad 28,50 \quad 506,3094,67(11)$ $(1,27>\phi>0,95 \mathrm{~cm})$

Maior perda de peso $(414,70 \mathrm{~g})$ durante os 12 primeiros ciclos (19 dias).

$3 / 8>\phi>\neq 478 / 124 \quad \ldots \quad-\quad-536,2047,70488,5091,10(12)$

$(0,95>\phi>0,47 \mathrm{~cm})$

Maior perda de peso $(320,10 \mathrm{~g})$ durante os 12 primeiros ciclos (19 dias). 
Tabela 33

Ciclagem ägua-estufa com os Arenitos Caiuä

$S R-4$

Profundidades $(\mathrm{m}) \quad$ Altitudes $(\mathrm{m})$

17,30 a $18,65 \quad 223,84$ a $222,49-(1)$ (2) (3) (4)

28,30 a 29,95

212,84 a $211,19-(5)(6)$ (7) (8) (9)

\begin{tabular}{|c|c|c|c|c|c|c|c|c|c|}
\hline A & B & C & D & $\mathrm{E}$ & $\mathrm{F}$ & G & $H$ & 1 & $\mathrm{~F}$ \\
\hline $\begin{array}{l}3>\phi>2^{\prime \prime} \\
(7,62>\phi>5\end{array}$ & $\begin{array}{c}6 / 7 \\
8 \mathrm{~cm})\end{array}$ & 6 & 0 & 6 & 100 & 1982,90 & 0,00 & 1982,90 & $100(1)$ \\
\hline Perda tota & durant & 01 & clo & dia & & & & & \\
\hline $\begin{array}{l}2>\phi>1^{11} \\
(5,08>\phi>2\end{array}$ & $\begin{array}{l}78 / 124 \\
4 \mathrm{~cm})\end{array}$ & 28 & 0 & 28 & 100 & 1494,00 & 115,40 & 1378,60 & $92,28(2)$ \\
\hline
\end{tabular}

Maior perda de peso $(1367,80 \mathrm{~g})$ durante os 12 primeiros ciclos (19 dias). Amostras afetadas desde o início. $1 / 2>\phi>3 / 8^{\prime 1} 78 / 124 \quad-\quad+\quad \cdots \quad 534,50 \quad 3,40 \quad 531,1099,36(4)$
$(1,27>\phi>0,95 \mathrm{~cm})$

Maior perda de peso $(519,80 \mathrm{~g})$ após os 12 primeiros ciclos (19 dias).

$3 / 8>\phi>\neq 4 \quad 78 / 124 \quad-\quad \ldots \quad-\quad \ldots \quad 527,20 \quad 2,20 \quad 525,0099,58(5)$

$(0,95>\phi>0,47 \mathrm{~cm})$

Maior perda de peso $(508,40 \mathrm{~g})$ durante os 12 primeiros ciclos (19 dias).

$\begin{array}{lllllllllll}3>\phi>2^{\prime \prime} & 06 / 08 & 5 & 0 & 5 & 100 & 1978,70 & 0,00 & 1978,70 & 100 & (6)\end{array}$

$(7,62>\phi>5,08 \mathrm{~cm})$

Perda total de peso apös 6 cíclos (8 dias).

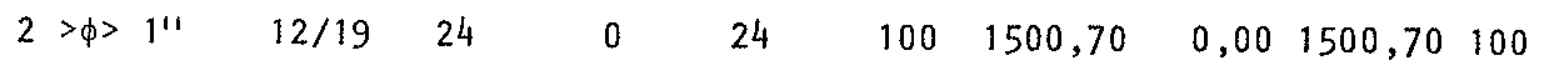

$(5,08>\phi>2,54 \mathrm{~cm})$

Perda total de peso apös 12 ciclos (19 dias).

$\begin{array}{lllllllllll}1>\phi>1 / 2^{\prime \prime} & 36 / 57 & 79 & 0 & 79 & 100 & 1003,60 & 0,00 & 1003,60 & 100 & (7)\end{array}$

$(2,54>\phi>1,27 \mathrm{~cm})$

Perda total de material após 12 ciclos (19 dias), igual a $998,40 \mathrm{~g}$.

$1 / 2>\phi>3 / 8^{\prime 1} 12 / 18 \quad-\quad \ldots \quad \ldots \quad \ldots \quad 529,10 \quad 0,00 \quad 529,1099,89(8)$

$(1,27>\phi>0,95 \mathrm{~cm})$

Maior perda de material $(514,90 \mathrm{~g})$ apös os 12 primeiros ciclos (19 dias).

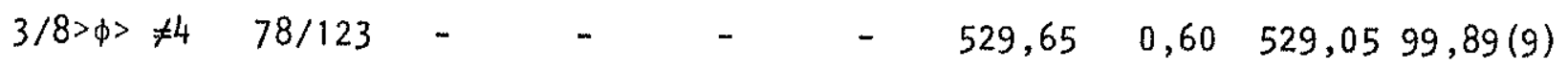

$(0,95>\phi>0,47 \mathrm{~cm})$ 
Tabela 34

Ciclagem ägua-estufa com os Arenitos Caiuä

$S R-5$

Profundidades $(m)$

Altitudes $(\mathrm{m})$

10,00 a 11,20

228,14 a 226,94

220,78 a 219,52

(1) (2) (3)

17,36 a 18,62

217,23 a 215,94

20,91 a 22,20

(5) (6)

$\begin{array}{crrrrrrrrrc}A & B & C & D & E & F & G & H & 1 & J \\ 3>\phi>22^{\prime \prime} & 1 & 5 & 0 & 5 & 100 & 1899,70 & 0,0 & 1899,70 & 100(1) \\ (7,62>\phi>5,08 \mathrm{~cm}) & & & & & & & & \end{array}$

Desintegração total apôs 13 horas.

$\begin{array}{llllllllll}2>\phi>111 & 1 & 32 & 0 & 32 & 100 & 1504,90 & 0,0 & 1504,90 & 100\end{array}$

$(5,08>\phi>2,54 \mathrm{~cm})$

Desintegração total apös 13 horas de imersão.

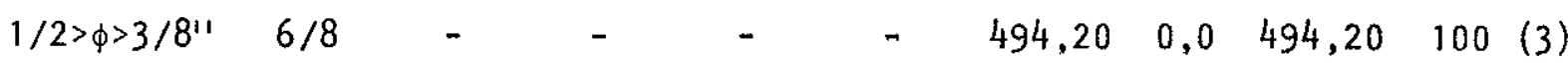

$(1,27>\phi>0,95 \mathrm{~cm})$

Desintegração total apös 6 ciclos ( 8 dias).

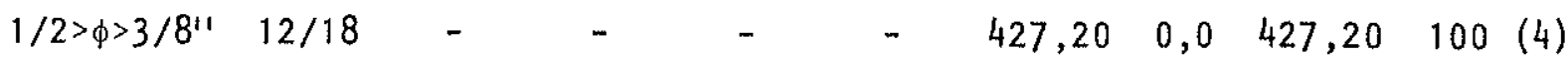

$(1,27>\phi>0,95 \mathrm{~cm})$

Maior perda de material $(418,70 \mathrm{~g})$ durante os 6 primeiros ciclos (8 dias).

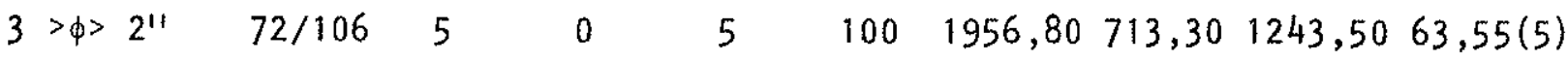

$(7,62>\phi>5,08 \mathrm{~cm})$

Amostras afetadas desde os 12 primeiros ciclos (19 dias). Maior perda de peso tambëm nesse período, igual a $731,20 \mathrm{~g}$.

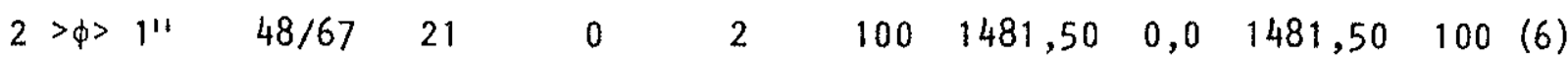

Amostras afetadas desde os 12 ciclos (19 dias) iniciais. Maior perda de pe so $(1265,50 \mathrm{~g})$ tambëm nesse período. 
Tabela 35

Ciclagem águarestufa com os Arenitos Caiuá

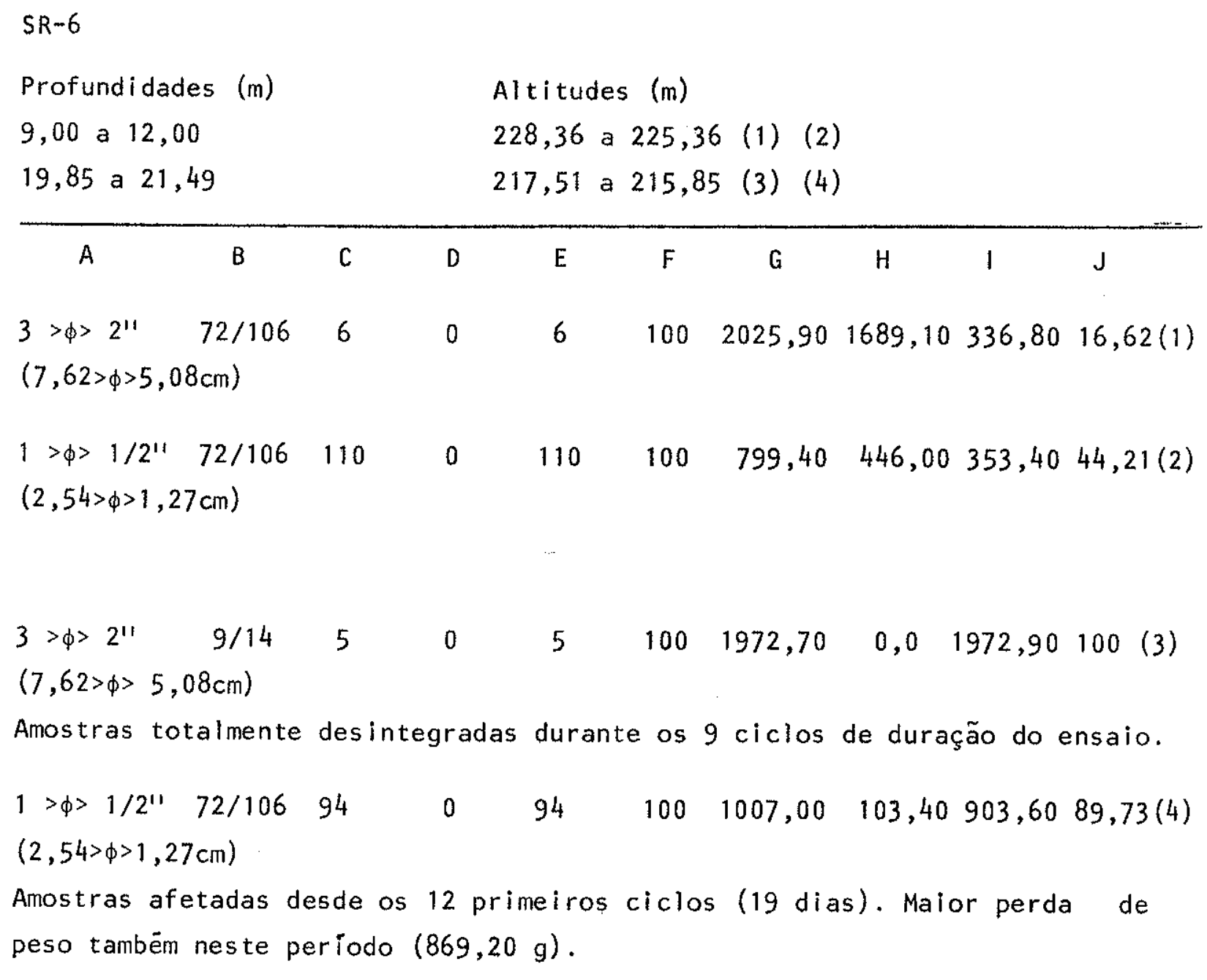


Tabela 36

Ciclagem água-estufa com os Arenitos Caiuä

$S R-7$

$\begin{array}{ll}\text { Profundidades }(m) & \text { Altitudes }(m) \\ 10,20 \text { a } 11,50 & 227,24 \text { a } 225,94(1)(2) \\ 21,60 \text { a } 23,15 & 215,84 \text { a } 214,29(3)(4) \quad(5) \text { (6) (7) } \\ 29,71 \text { a } 31,27 & 207,73 \text { a } 206,17(8)(9)(10)(11) \quad(12\end{array}$

$\begin{array}{lllllllllll}A & B & C & D & E & F & G & H & 1 & J\end{array}$

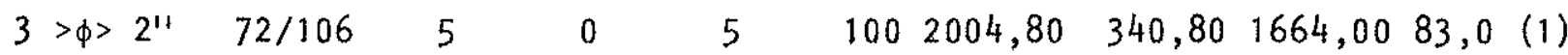

$(7,62>\phi>5,08 \mathrm{~cm})$

$2>\phi>1^{11} \quad 72 / 106 \quad 39 \quad 0 \quad 39 \quad 100 \quad 1499,90 \quad 25,80 \quad 1474,1098,28(2)$

$(5,08>\phi>2,54 \mathrm{~cm})$

$3>\phi>2^{11} \quad 72 / 106 \quad 6 \quad 0 \quad 6 \quad 6 \quad 100 \quad 1610,80 \quad 566,00 \quad 1044,80 \quad 64,86(3)$

$(7,62>\phi>5,08 \mathrm{~cm})$

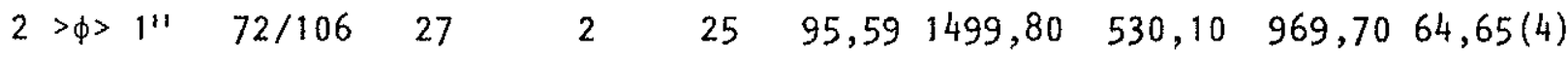

$(5,08>\phi>2,54 \mathrm{~cm})$

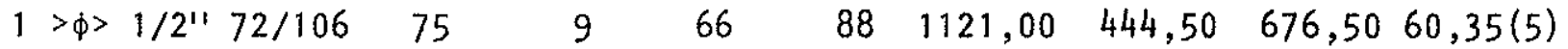

$(2,54>\phi>1,27 \mathrm{~cm})$

$1 / 2>\phi>3 / 8^{\prime \prime} 72 / 106$

$-\quad 456,20 \quad 71,60 \quad 384,6084,30(6)$

$(1,27>\phi>0,95 \mathrm{~cm})$

$3 / 8>\phi>\neq 4 \quad 72 / 106$

$(0,95>\phi>\quad \mathrm{cm})$

$\begin{array}{lllllllllll}3>\phi>211 & 12 / 19 & 4 & 0 & 4 & 100 & 1939,50 & 0,0 & 1939,50 & 100 & (8)\end{array}$

$(7,62>\phi>5,08 \mathrm{~cm})$

$\begin{array}{lllllllllll}2>\phi>11 & 12 / 19 & 28 & 0 & 28 & 100 & 1451,80 & 0,0 & 1451,80 & 100 & \text { (9) }\end{array}$

$(5,08>\phi>2,54 \mathrm{~cm})$

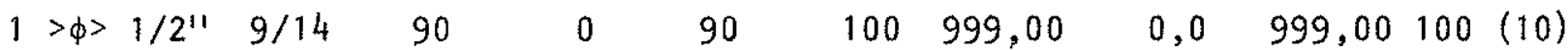

$(2,54>\phi>1,27 \mathrm{~cm})$

$1 / 2>\phi>3 / 8^{\prime \prime} 12 / 19 \quad-\quad \ldots \quad \ldots \quad-\quad 466,40 \quad 0,0 \quad 466,40100(11)$

$(1,27>\phi>0,95 \mathrm{~cm})$

$\begin{array}{lllllllll}3 / 8>\phi>-4 & 19 / 38 \quad-501,70 & 0,0 & 521,70 & 100(12)\end{array}$

$(0,95>\phi>0,47 \mathrm{~cm})$ 
Tabela 36 - folha 2

Todas as amostras foram afetadas desde o início dos ensalos.

No caso dos ensaios representados pelas linhas (8) (9) e (11), as amostras desintegraram-se totalmente apös $12 \mathrm{ciclos}$ (19 dias).

Amostras representadas pela linha $(10)$, desintegraram-se totalmente apös 9 ciclos (14 dias).

As representadas na linha (12) perderam maior peso $(504,60 \mathrm{~g})$ apös $12 \mathrm{ci}$ clos iniciais (19 dias).

Tabela 37

Ciclagem ägua-estufa com os Arenitos Caiuä

$S R-8$

Profundidades $(\mathrm{m}) \quad$ Altitudes $(\mathrm{m})$

14,60 a $15,65 \quad 227,02$ a 225,97 (1) (2) (3)

28,72 a 30,32 212,90 a $211,30(4)$

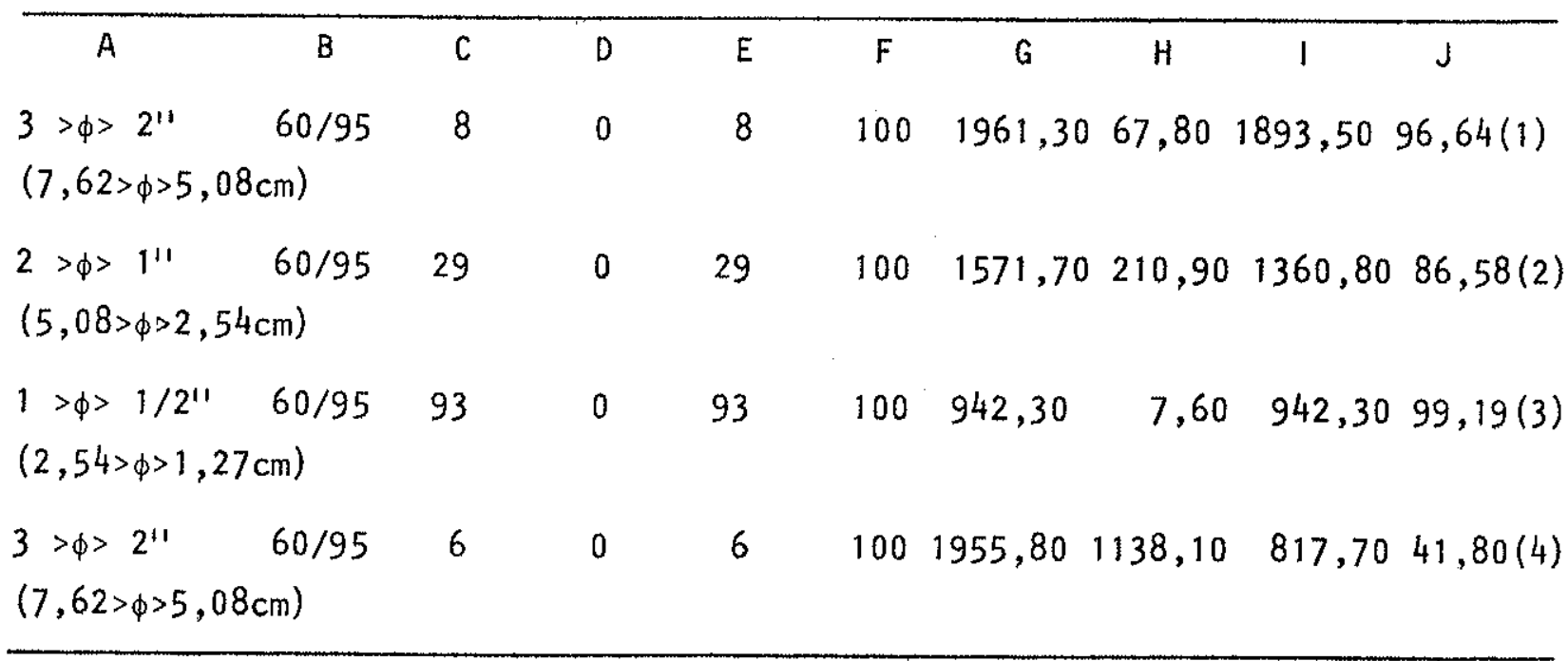

Todas as amostras afetadas desde os 12 primeiros ciclos (19 dias) iniciais. Para a amostra representada na linha (1), a maior perda de peso $(1404,10 \mathrm{~g})$ deu-se tambëm naquele período.

Para as amostras representadas nas linhas (2) e (3), as maiores perdas de peso deram-se também nos 12 primeiros ciclos (19 dias) e tiveram os valores de, respectivamente $1118,10 \mathrm{~g}$ e $840,50 \mathrm{~g}$.

Para a amostra representada pela linha (4), a maior perda de peso deu-se apös 24 ciclos iniciais (39 dias), no valor de $612,90 \mathrm{~g}$. 
FIG. 14 - ENSAIO DE CICLAGEM NATURAL - Amostras provenlentes do Local II

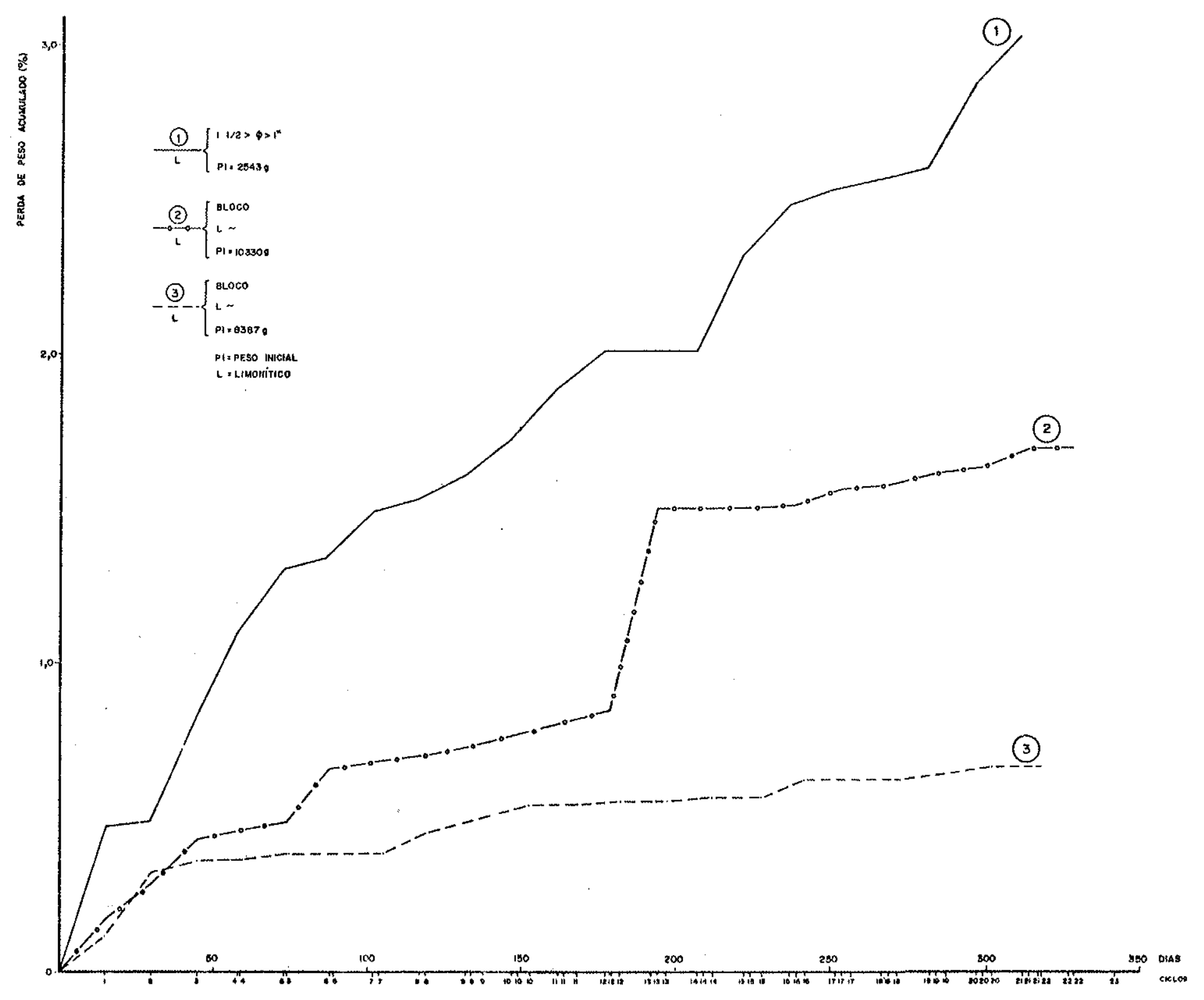




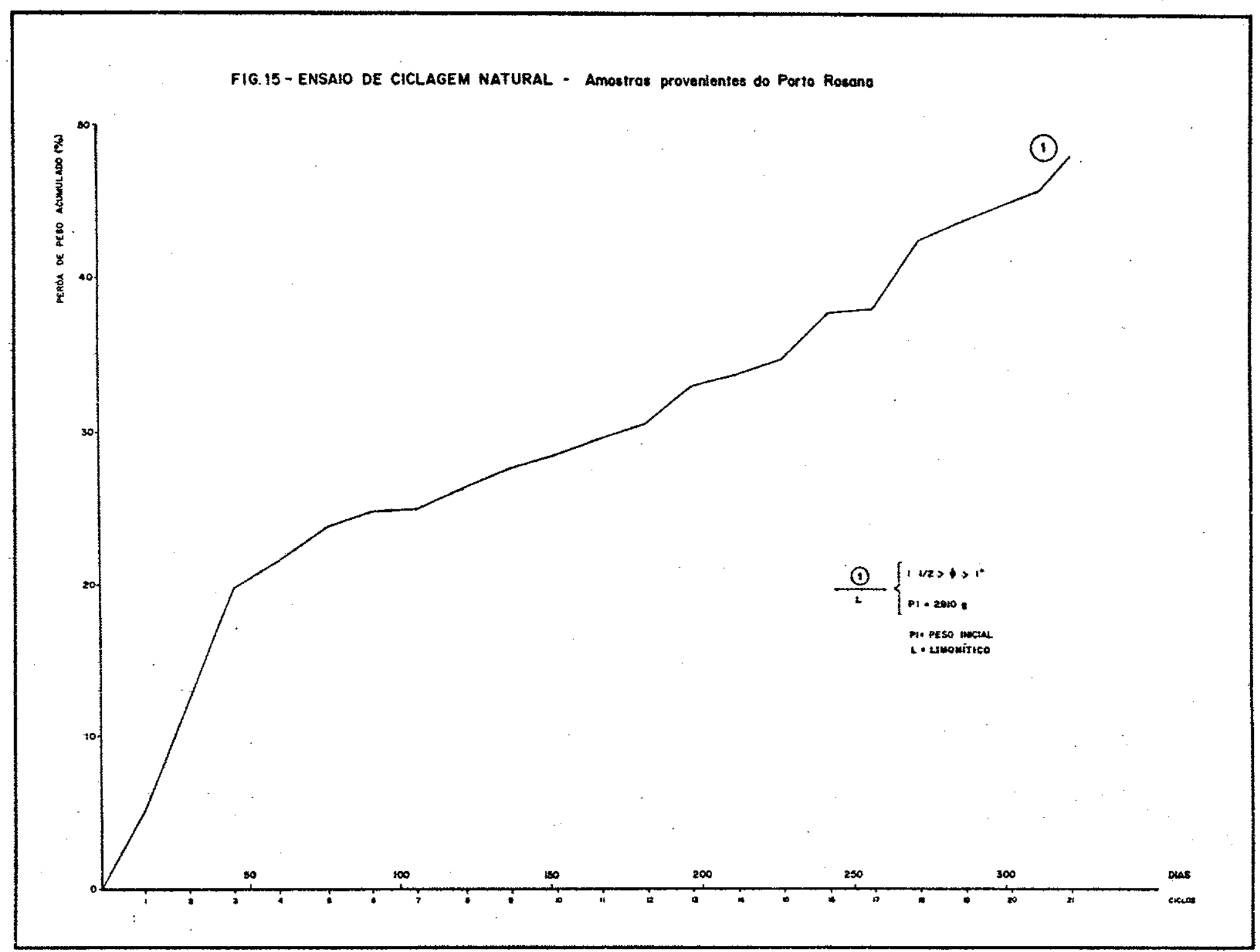




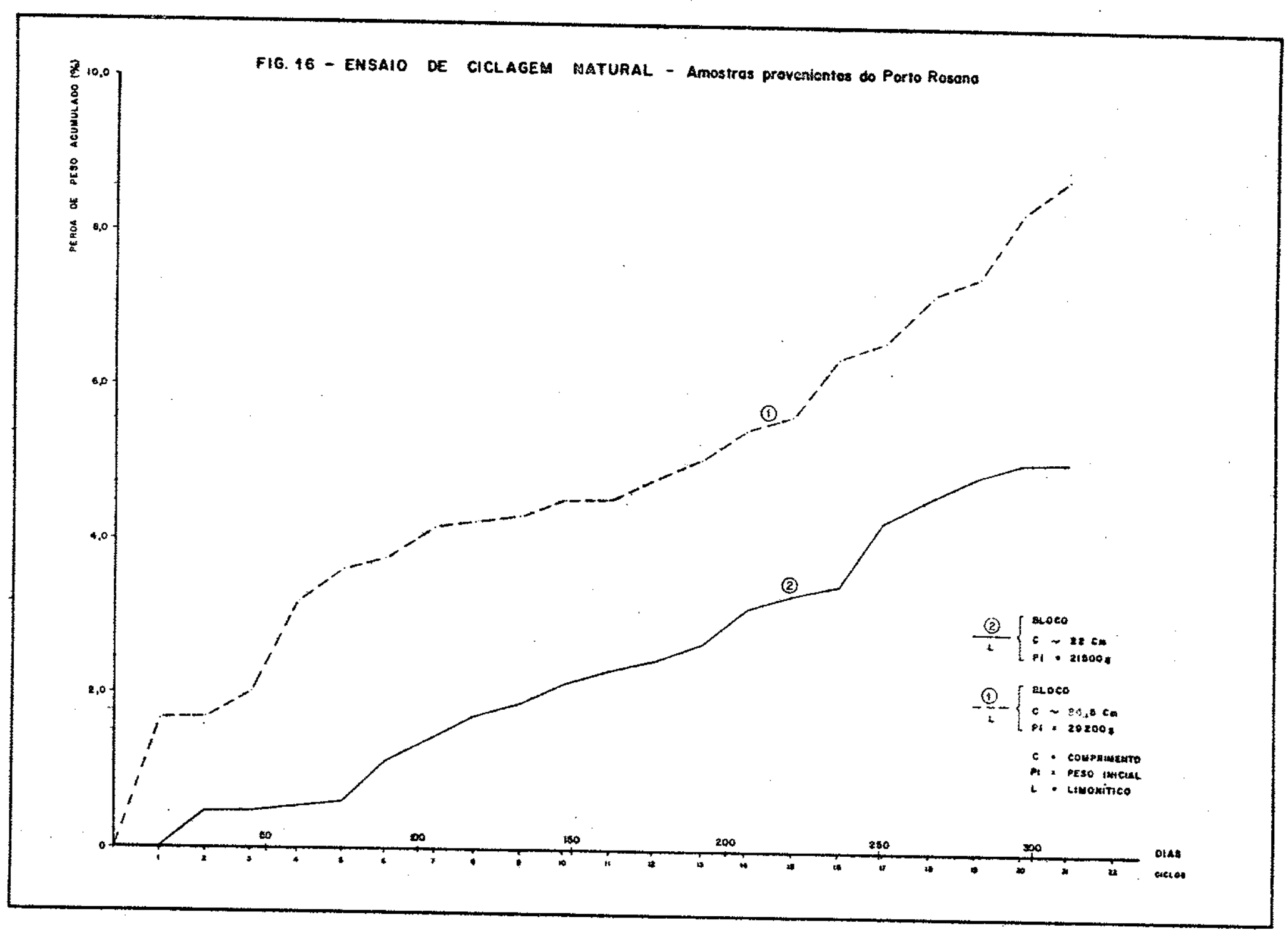




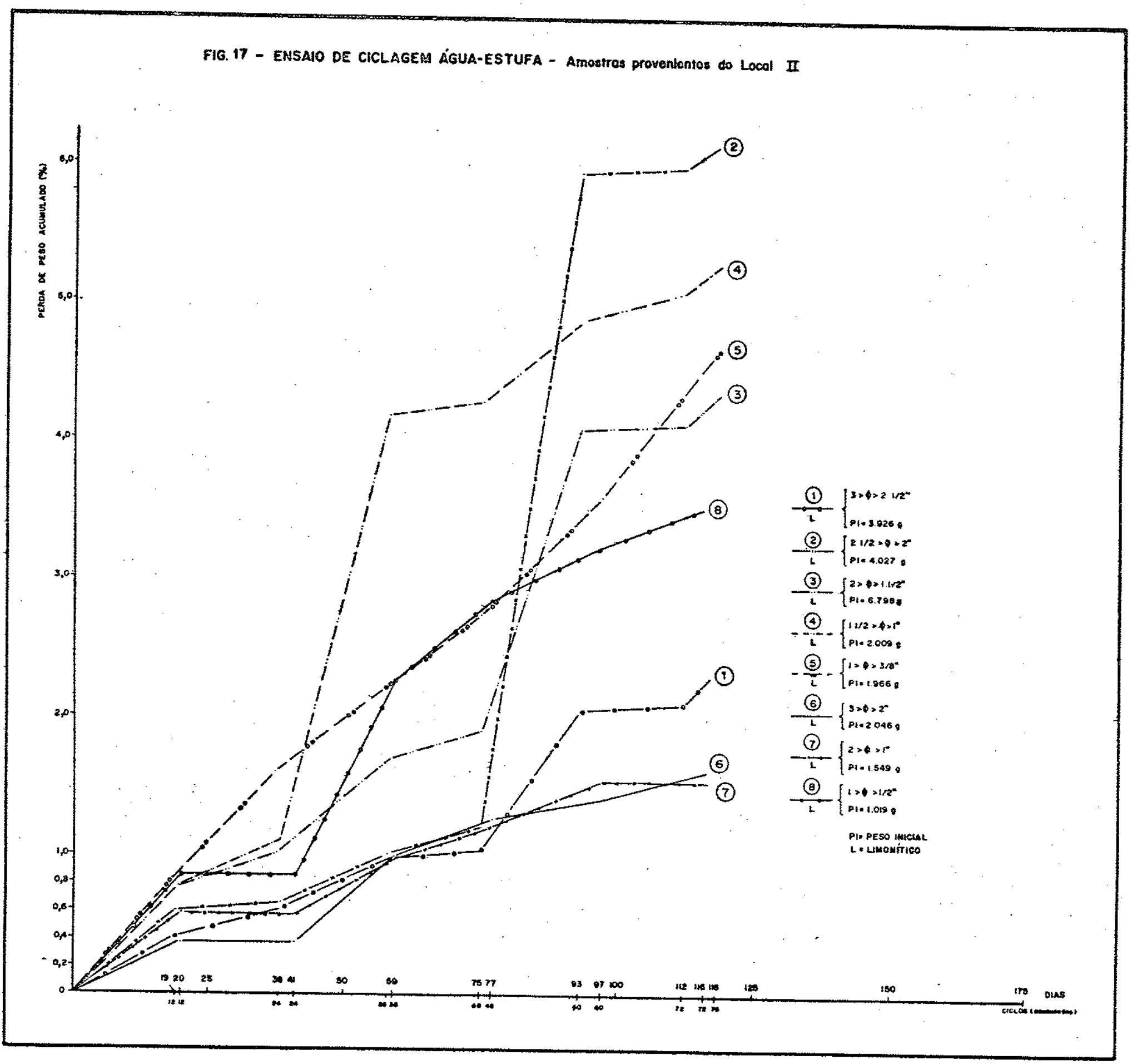




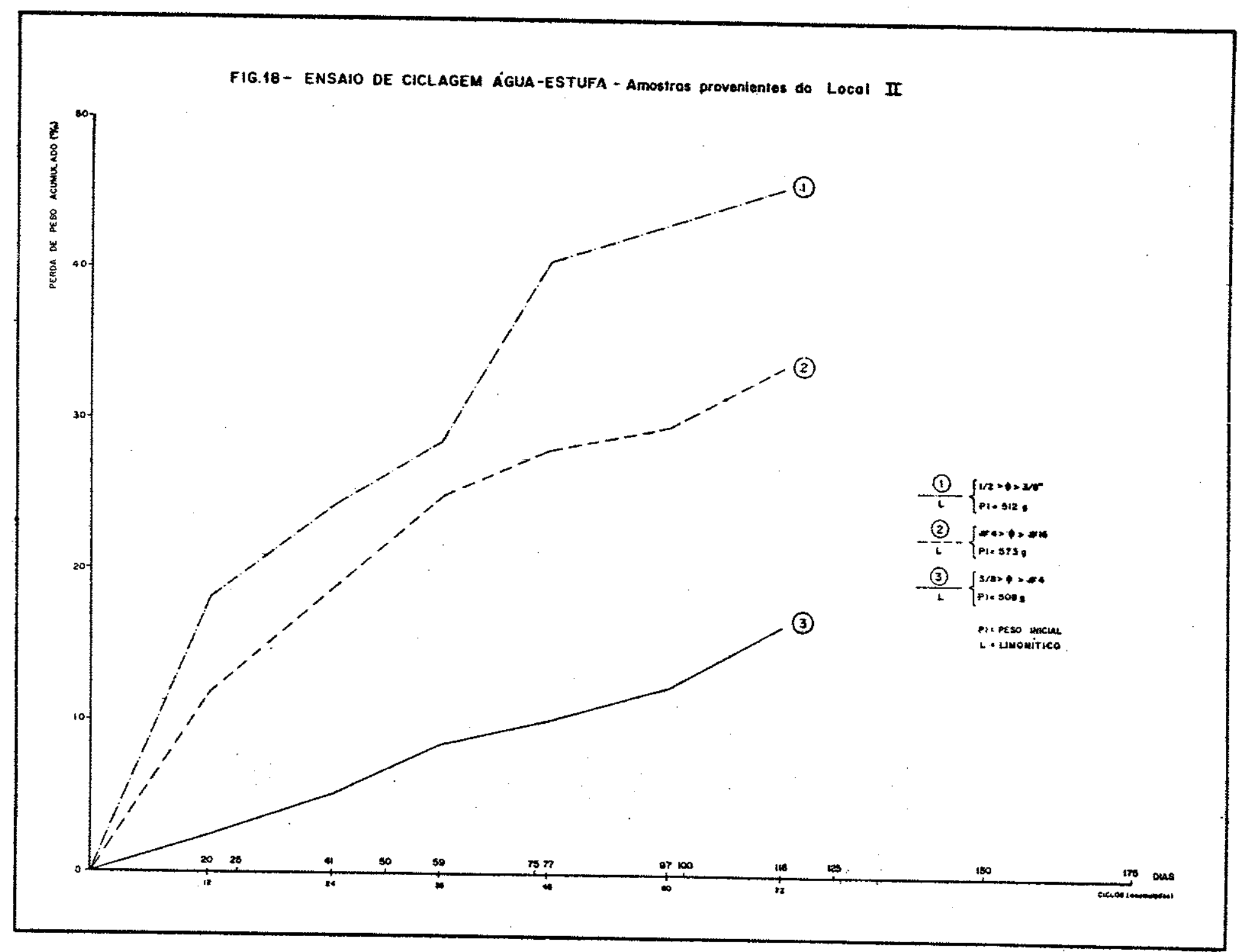




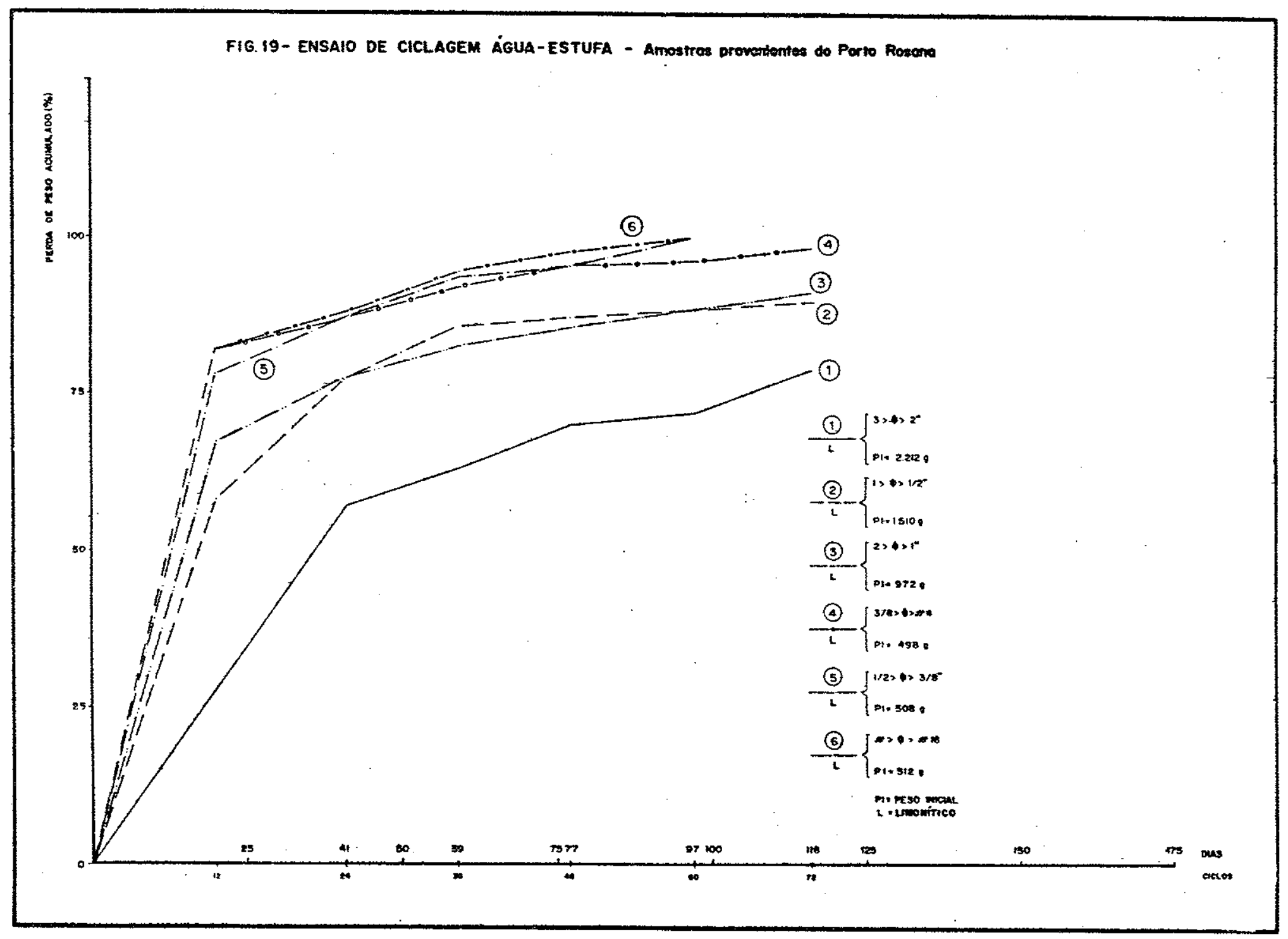




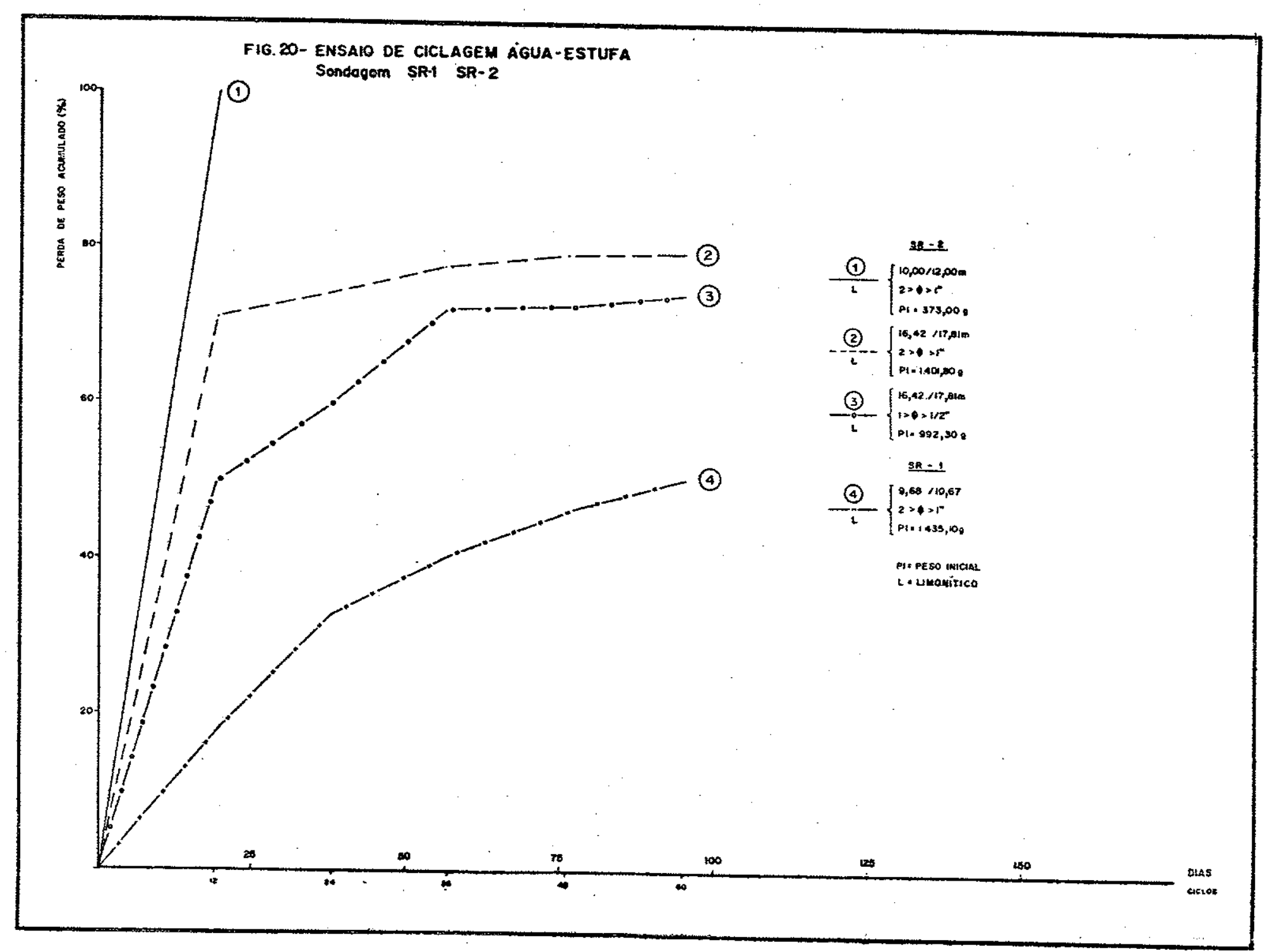




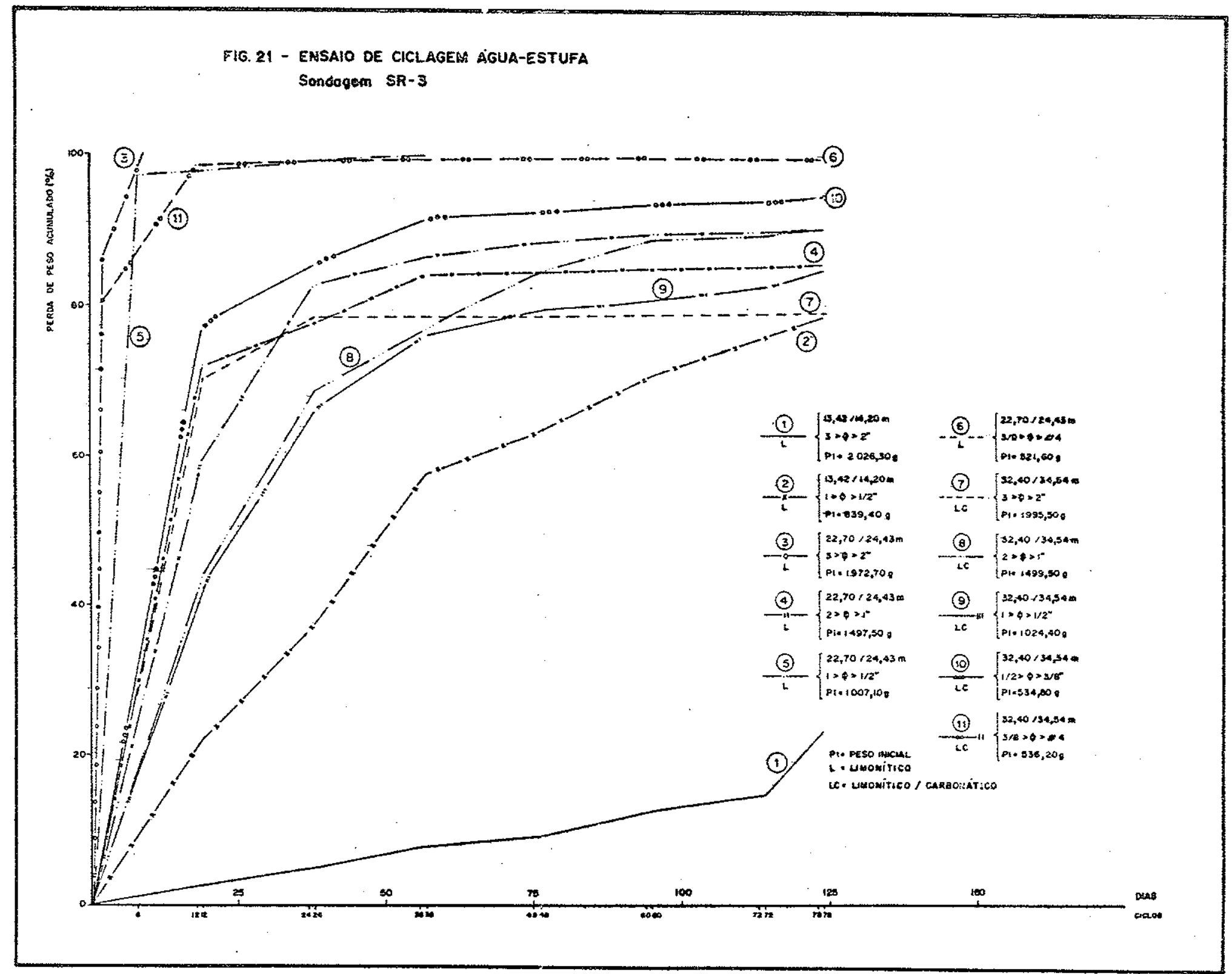




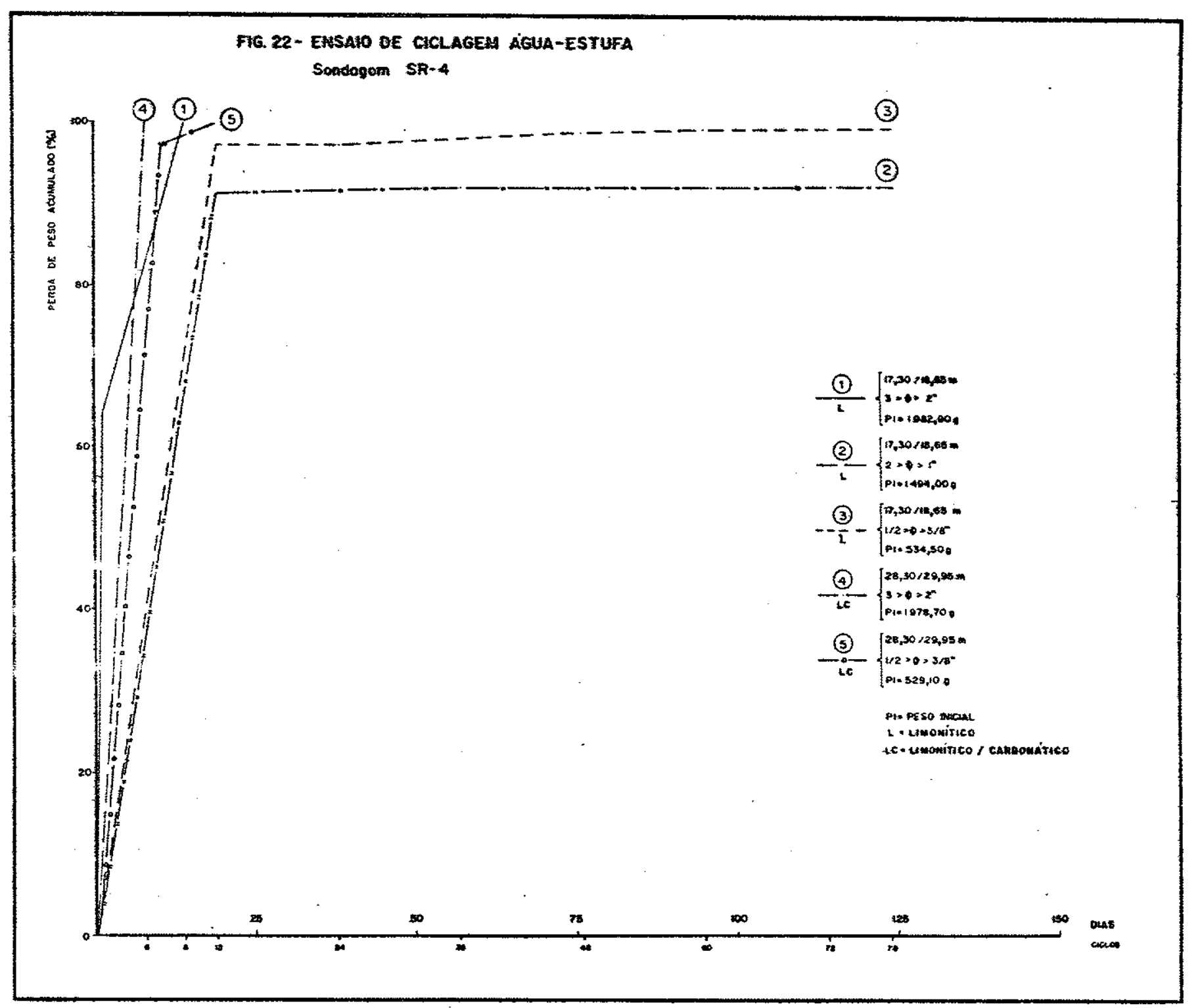




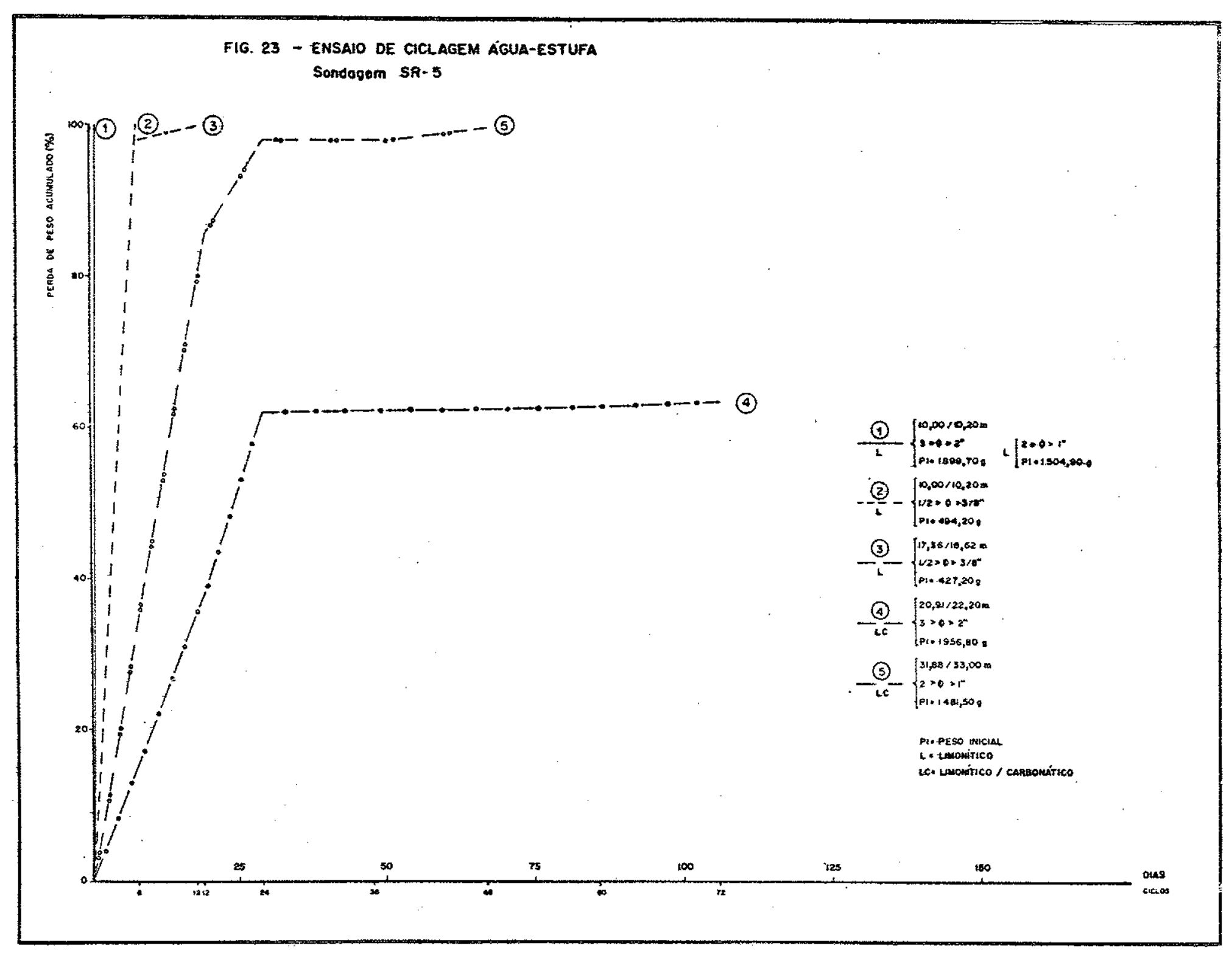

$\stackrel{\sim}{\infty}$ 


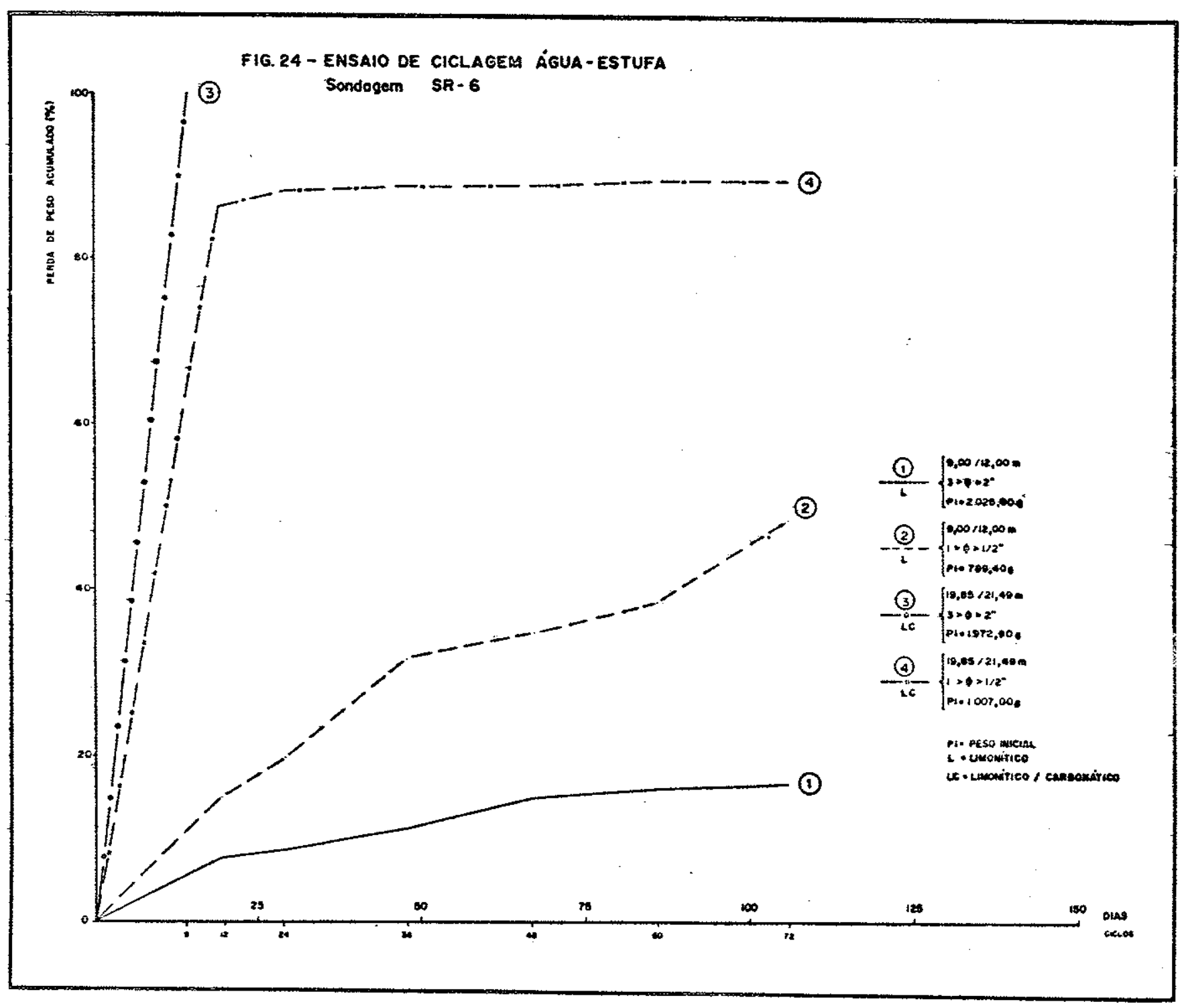




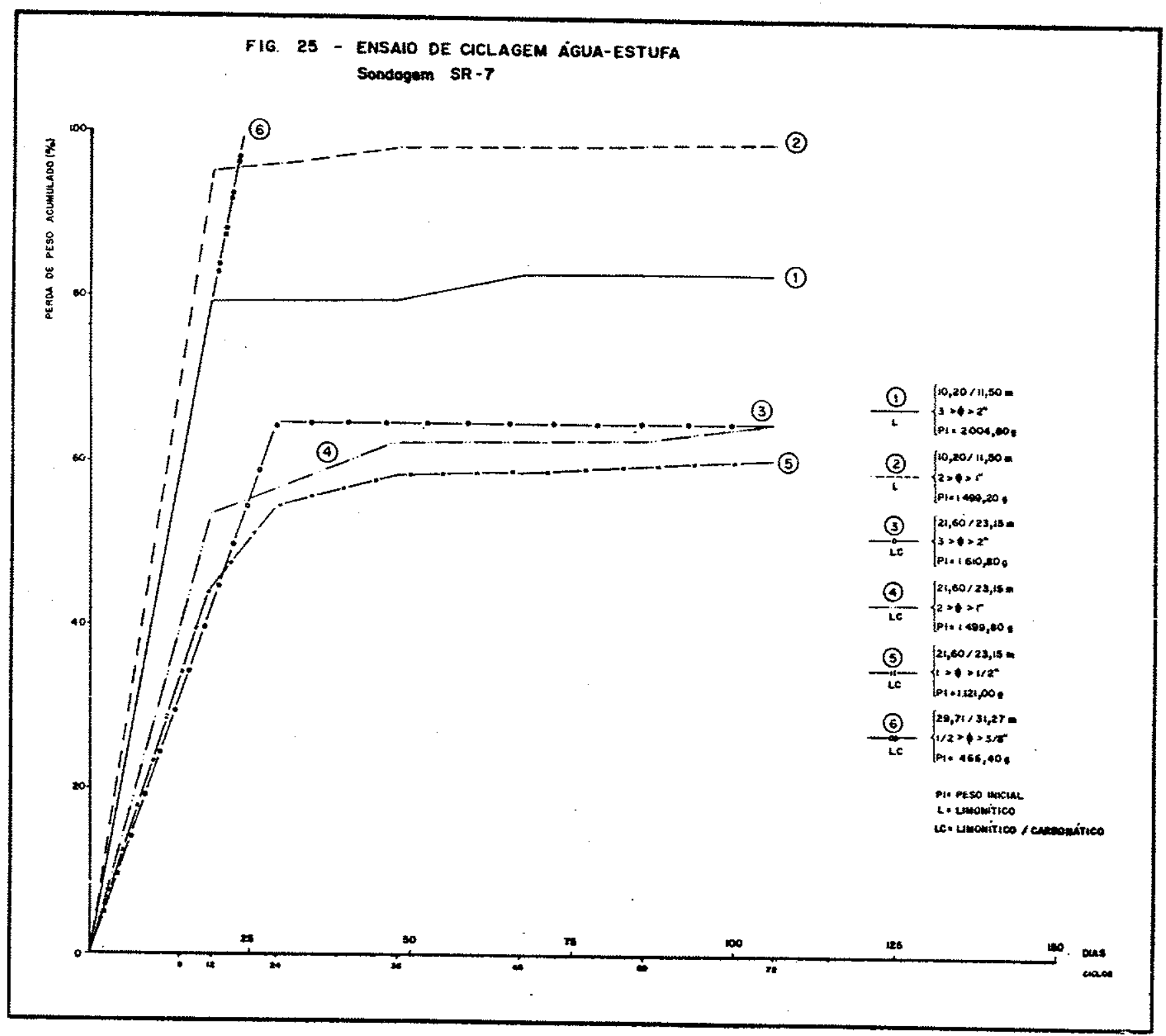




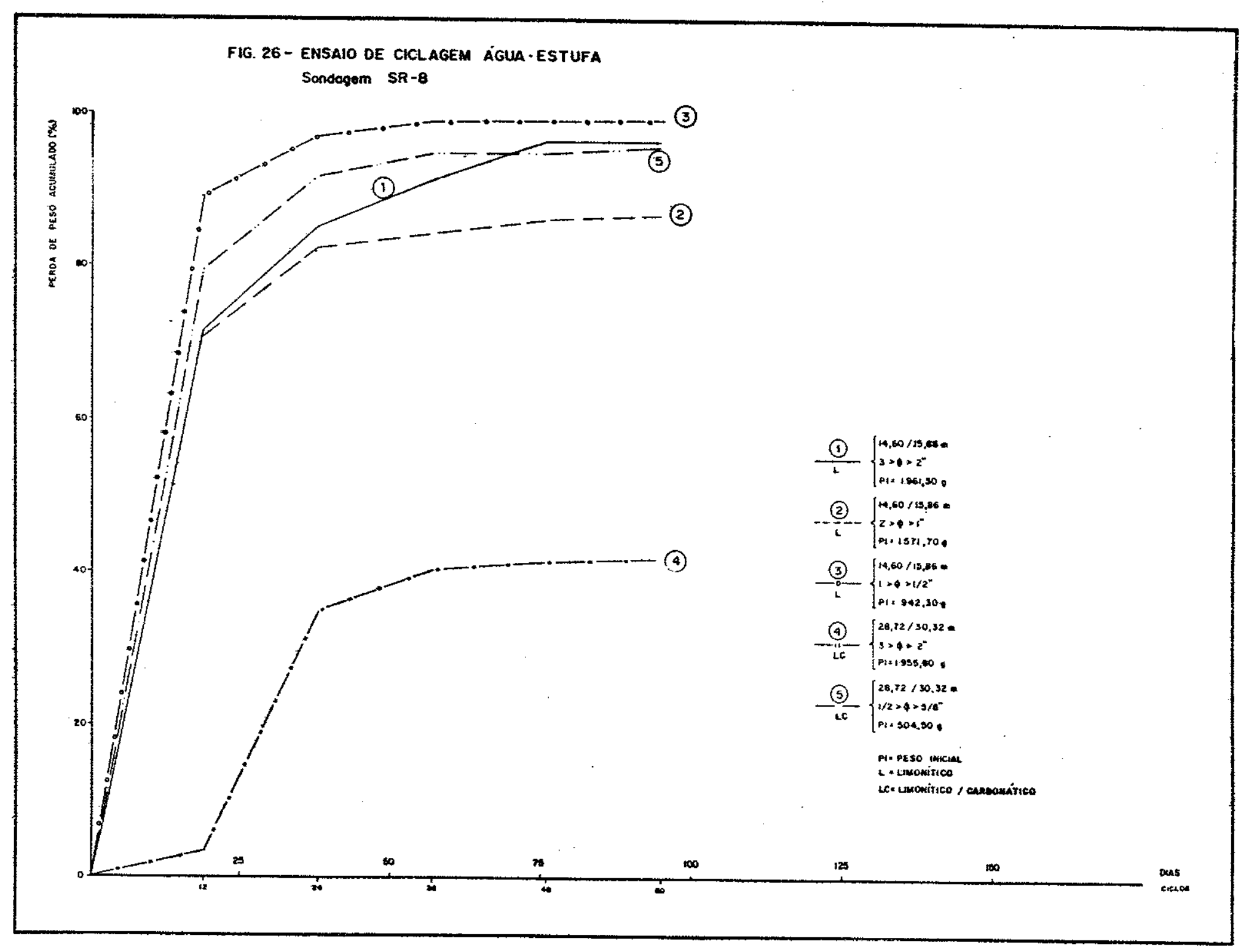

$\stackrel{\omega}{\omega}$ 


\section{Considerações sobre os Ensaios de Ciclagem}

Algumas conclusões são mais ou menos evidentes, a partir do exame das figuras nümeros 14 a 26.

No que se refere à circlagem natural com amostras provenientes do local 11 , nota-se que dos blocos de grandes dimensōes foi mais sensível ao processo o maior deles, mas mesmo assim a perda total de material relativamente ao peso inicial foi da ordem de $1,6 \%$. A amostra de menor granulo metria $\left(11 / 2^{\prime \prime}>\phi>1^{\prime \prime}\right.$ ou $\left.3,81>\phi>2,54 \mathrm{~cm}\right)$ perdeu cerca de $3 \%$ de seu pröprio peso, durante o processo.

Para as amostras provenientes do local 1, a tendência foi a mes ma. Porëm, para blocos de grandes dimensöes, foi de cerca de $8 \%$ e para as amostras de pequenas dimensões, quase $50 \%$. Essa diferença de comportamento entre exemplares dos dois locais explica-se pelo fato das primeiras terem sofrido processos de ferruginização secundäria.

Quanto à ciclagem acelerada âgua estufa as amostras provenientes do primeiro local comportammse mais ou menos aleatoriamente; todavia, a tendência ë de uma maior perda de peso (1 a 6\% entre 40 e 97 dias do inicio (24 e 60 ciclos). A perda total pode ser considerada pequena, correspondente a até $6 \%$ do peso inicial. A ferruginização secundäria ê respon sävel por esse comportamento. A influência da granulometria é grande, sendo mais sensiveis ã ciclagem os exemplares de frações granulomētricas meno res, mas hä casos em que se nota o conträrio. As amostras de dimensōes muj to pequenas são extremamente mais sensiveis, perdendo entre 16 e $46 \%$ do pe so inicial.

Nas amostras do local 1, hă uma evidente influência da granulome tria no processo. Exemplares maiores $\left(3^{\prime \prime}>\phi>2^{\prime \prime}\right.$ ou $7,62>\phi>5,08 \mathrm{~cm}$ ) são menos cicläveis que os menores $(\not 4>\phi>\not 16$ ou $0,47>\phi>0,12 \mathrm{~cm}$ ), porëm a perda de peso para todas as amostras é significativa, variando de pouco mais de 75 a $100 \%$. Observou-se que as maiores perdas de peso (de 55 a $85 \%$ ) acontecem atê os 40 primeiros dias $(24$ ciclos) para um total de 116 dias (72 ciclos).

Relativamente às amostras de sondagens, o que se nota é que, no geral, elas ciclam-se violentamente no primeiro terço ou atë a metade do período de ciclagem correspondente, com grande perda de peso. Não se notou praticamente a influência do cimento limonitico ou limonítico-carbonätico ou da profundidade no processo, a não ser em alguns casos isolados, onde 
uma maior resistência à desagregação ê devida, como jä nos referimos, à ferruginização secundäria. 0 que se pode finalmente deduzir quanto aos enm saios de ciclagem natural e ägua estufa com os Arenitos Caiuä è o seguinte:

a) A influência da granulometria é muito sensivel quando se tra ta da comparação entre exemplares grandes (tamanho de blocos) com os da ordem de polegadas. Acredita-se que, sendo o processo de desagregação dos arenitos pela destruição do cimento ou matriz argilosa função do tempo e das possibilidades de ataque da ãgua, parece öbvio que os blocos de gran des dimensões opõem uma sensível dificuldade à ação da ägua. A duração do ensaio de ciclagem natural, no que se refere aos blocos, se fosse maior talvez fornecesse dados importantes sobre a possivel aceleração do processo, depois de determinado tempo, quando fosse facilitado o trabalho de per colação da ägua.

b) Entende-se que os ensaios de ciclagem natural sejam mais confiäveis na interpretação do comportamento da rocha, por representarem eles pröprios o trabalho real dos agentes intempëricos. Os ensaios de ciclagem acelerada são bastante üteis porëm seus resultados são de difícil correla ção com o comportamento natural da rocha, mesmo para aplicações onde ela esteja sujeita a ciclos severos de umidecimento e secagem, como no caso de um enrocamento na zona de oscilação do nível do reservatörio.

c) A influência do cimento carbonätico na resistência dos arenitos parece ser menos sensivel do que a influência de produtos de limonitização secundäria acrescidos ao maciço.

\section{Ensaios mecânicos}

\section{Resistência ao Impacto Treton}

Para os materiais do local 11 , foram realizados dois ensaios "in natura", 4 para amostras anteriormente submetidas a ciclagem com extrator Soxlhet, e 3 com amostras submetidas preliminarmente à ciclagem ãgua-estufa.

Relativamente às amostras do local 1 , foi realizado 1 ensaio com material "in natura", 4 ensaios com material anteriormente submetido à ciclagem no extrator Soxlhet e 1 com material preliminarmente submetido à ciclagem água-estufa. Cada amostra considerada foi composta de 20 fragmentos. 
Nas tabelas nümeros 38 a 51 , podemse observar os resultados dos ensaios no apareltho Treton, valendo para os mesmos as seguintes convenções:

$$
\begin{aligned}
& P_{1}=\text { Peso inicial, em gramas } \\
& P_{s}=\text { Peso apös secagem em estufa, em gramas } \\
& P_{f}=\text { Peso final, apös ensaio, retido na peneira 12, em gramas } \\
& T=\text { Resistência ao Impacto Treton }
\end{aligned}
$$

Material: Arenito Caiuä limonítico

Procedencia: local II

Faixa granulométrica: $3 / 4>\phi>1 / 2^{\prime \prime}(1,90>\phi>1,27 \mathrm{~cm})$

Tabela 38

Resistência ao impacto Treton com os Arenitos Caiuä Material "in natura"

\begin{tabular}{cccc}
\hline & 1 \% ensaia & 2 \% ensaio & 3\% ensaio \\
$P_{i}$ & 146,14 & 147,13 & 149,78 \\
$P_{s}$ & 145,48 & 146,50 & 149,00 \\
$P_{f}$ & 27,33 & 24,66 & 24,38 \\
$T$ & 81,21 & 83,17 & 83,67 \\
\hline$\vec{x}$ (mêdia) & & 82,67 &
\end{tabular}

Tabela 39

Resistência ao impacto Treton com os Arenitos Caiuä Material "in natura"

\begin{tabular}{cccc}
\hline & 1 e ensaio & 2 e ensaio & 39 ensaio \\
$P_{i}$ & 157,41 & 163,80 & 140,20 \\
$P_{S}$ & 156,90 & 163,50 & 139,80 \\
$P_{f}$ & 25,55 & 28,87 & 22,07 \\
$T$ & 83,72 & 82,37 & 84,21 \\
\hline $\bar{x}$ (média) & & 83,43
\end{tabular}


Tabela 40

Resistência ao impacto Treton com os Arenitos Caiuä

\begin{tabular}{cccc} 
& 19 ensaio & 20 ensaio & 30 ensaio \\
$\mathrm{P}_{\mathrm{i}}$ & 91,32 & 114,90 & - \\
$\mathrm{P}_{\mathrm{S}}$ & 90,81 & 114,29 & - \\
$\mathrm{P}_{f}$ & 10,09 & 14,23 & - \\
$\mathrm{T}$ & 88,89 & 87,55 & - \\
\hline $\bar{x}$ (mëdia) & & 88,22 &
\end{tabular}

Amostras submetidas a 100 ciclos de ciclagem acelerada com extrator Soxhlet.

Tabela 41

Resistência ao impacto Treton com os Arenitos Caiuá

\begin{tabular}{cccc} 
& 19 ensaio & 2\% ensaio & 3\% ensaio \\
$\mathrm{P}_{\mathrm{i}}$ & 100,33 & 105,27 & - \\
$\mathrm{P}_{\mathrm{S}}$ & 97,12 & 104,69 & - \\
$\mathrm{P}_{\mathrm{f}}$ & 12,20 & 12,70 & \\
$\mathrm{~T}$ & 87,44 & 87,87 & \\
\hline $\bar{x}$ (mëdia) & 87,66 &
\end{tabular}

Amostras submetidas a 100 ciclos de ciclagem acelerada com extrator Soxhlet.

Tabela 42

Resistência ao impacto Treton com os Arenitos Caiuä

Amostras submetidas a 100 ciclos de ciclagem acelerada com extrator Soxhlet.

\begin{tabular}{ccc} 
& 1 \% ensaio & 20 ensaio \\
$\mathrm{P}_{\mathrm{i}}$ & 118,03 & 93,30 \\
$\mathrm{P}_{\mathrm{S}}$ & 117,20 & 92,78 \\
$\mathrm{P}_{\mathrm{f}}$ & 17,27 & 9,80 \\
$\mathrm{~T}$ & 85,26 & 89,44 \\
\hline $\bar{x}$ (média) & 87,35 &
\end{tabular}


Tabela 43

Resistência ao impacto Treton com os Arenitos Caiuä Amostras submetidas a 100 ciclos de ciclagem acelerada com extrator Soxhlet.

\begin{tabular}{ccc} 
& 1 \% ensaio & 2 ensaio \\
$P_{i}$ & 117,57 & 96,05 \\
$P_{s}$ & 116.90 & 95,60 \\
$P_{f}$ & 16,52 & 9,40 \\
$T$ & 85,87 & 90,17 \\
\hline $\bar{x}$ (mëdia) & 88,02 &
\end{tabular}

Tabela 44

Resistência ao impacto Treton com os Arenitos Caiuä

Amostras submetidas ao ensaio de ciclagem acelerada ägua-estufa com a dura ção de 72 ciclos

\begin{tabular}{cccc} 
& 1 \% ensaio & 2 \% ensaio & 3\% ensaio \\
$P_{i}$ & 124,40 & 122,55 & 137,45 \\
$P_{S}$ & 123,70 & 121,85 & 136,70 \\
$P_{f}$ & 21,70 & 17,80 & 22,90 \\
$T$ & 82,46 & 85,39 & 83,25 \\
\hline $\bar{x}$ (mëdia) & & 83,70 &
\end{tabular}

Tabela 45

Resistência ao impacto Treton com os Arenitos Caiuä Amostras submetidas a 72 ciclos de ciclagem acelerada ägua-estufa

\begin{tabular}{cccc} 
& 1 \% ensaio & 2 \% ensaio & 3\% ensaio \\
$P_{i}$ & 120,35 & 138,30 & 129,10 \\
$P_{S}$ & 119,50 & 137,40 & 128,30 \\
$P_{f}$ & 19,00 & 26,20 & 20,10 \\
$T$ & 84,10 & 80,93 & 84,33 \\
\hline $\bar{x}$ (mëdia) & & 83,12 &
\end{tabular}


Tabela 46

Resistência ao impacto Treton com os Arenitos Caiuá Amostras submetidas a 72 ciclos de ciclagem acelerada ägua-estufa.

\begin{tabular}{lccc}
\hline & 10 ensaio & 2 e ensaio & 3 e ensaio \\
$P_{i}$ & 126,65 & 125,75 & 118,60 \\
$P_{s}$ & 125,90 & 125,10 & 117,90 \\
$P_{f}$ & 19,60 & 19,00 & 14,20 \\
$T$ & 84,43 & 84,81 & 87,96 \\
\hline $\bar{x}$ (mëdia) & & 85,73
\end{tabular}

Material: Arenito Caiuã limonítico

Procedência: local I

Faixa granulométrica: $3 / 4>\phi>1 / 2^{\prime \prime}(1,90>\phi>1,27 \mathrm{~cm})$

Tabela 47

Resistência ao impacto Treton com os Arenitos Caiuä

Material "in natura"

\begin{tabular}{cccc}
\hline & 1 e ensaio & 2 e ensaio & 3 ensaio \\
$P_{i}$ & 132,80 & 148,22 & 157,50 \\
$P_{S}$ & 132,11 & 147,37 & 156,79 \\
$P_{f}$ & 0,00 & 0,27 & 0,12 \\
$T$ & 100,00 & 99,82 & 99,92 \\
\hline$\vec{x}$ (mëdia) & & 99,91 &
\end{tabular}


Tabela 48

Resistência ao impacto Treton com os Arenitos Caiuã

Amostras submetidas preliminarmente a 100 ciclos de ciclagem acelerada com extrator Soxhlet.

\begin{tabular}{lccc} 
& 1 19 ensaio & 29 ensaio & 39 ensaio \\
$P_{i}$ & 93,60 & 84,90 & 89,60 \\
$P_{S}$ & 92,00 & 83,00 & 87,50 \\
$P_{f}$ & 3,50 & 1,70 & 1,55 \\
$T$ & 96,20 & 97,95 & 98,23 \\
\hline $\bar{x}$ (média) & & 97,46 &
\end{tabular}

Tabela 49

Resistência ao impacto Treton com os Arenitos Caiuá

Amostras submetidas a $100 \mathrm{ciclos}$ de ciclagem acelerada ägua-estufa.

\begin{tabular}{ccc} 
& 1 \% ensaio & 2 \% ensaio \\
$\mathrm{P}_{i}$ & 109,00 & 113,20 \\
$\mathrm{P}_{S}$ & 105,90 & 110,70 \\
$\mathrm{P}_{f}$ & 4,20 & 3,20 \\
$T$ & 96,03 & 97,11 \\
\hline$\vec{x}$ (mëdia) & 96,57 &
\end{tabular}

Tabela 50

Resistência ao impacto Treton com os Arenitos Caiuä Amostras submetidas preliminarmente a $100 \mathrm{ciclos}$ de ciclagem acelerada no extrator Soxhlet.

\begin{tabular}{cccc} 
& 1 \% ensaio & 2 e ensaio & 3 e ensaio \\
$P_{i}$ & 89,00 & 74,10 & 89,00 \\
$P_{S}$ & 86,70 & 12,00 & 85,60 \\
$P_{f}$ & 2,15 & 1,00 & 2,05 \\
$T$ & 97,52 & 98,61 & 97,61 \\
\hline $\bar{x}$ (mëdia) & & 97,91 &
\end{tabular}


Tabela 51

Resistência ao impacto Treton com os Arenitos Caiuä

Amostras submetidas preliminarmente a 100 ciclos de ciclagem acelerada no extrator Soxhlet.

\begin{tabular}{|c|c|c|c|}
\hline & $1 \%$ ensaio & 2 e ensaio & $3{ }^{\circ}$ ensaio \\
\hline$P_{i}$ & 94,60 & 78,50 & 66,90 \\
\hline$P_{s}$ & 92,20 & 76,00 & 64,80 \\
\hline$P_{f}$ & 3,40 & 1,10 & 0,45 \\
\hline $\mathrm{T}$ & 96,31 & 98,55 & 99,30 \\
\hline
\end{tabular}

Tabela 52

Resistência ao impacto Treton com os Arenitos Caiuä

Amostras submetidas preliminarmente a 72 ciclos de ciclagem acelerada ägua -estufa.

\begin{tabular}{ccc} 
& 1 1: ensaio & 2\% ensaio \\
$P_{i}$ & 104,60 & 98,10 \\
$P_{s}$ & 103,65 & 97,15 \\
$P_{f}$ & 5,50 & 2,00 \\
$T$ & 94,69 & 97,94 \\
\hline $\bar{x}$ (mêdia) & 96,32 &
\end{tabular}

Consideraçöes relativas aos ensaios de resistência ao impacto Treton

Naturalmente a situação ideal para um determinado material sob as condições do ensaio em questão, ê que os resultados obtidos sejam os mais baixos possiveis. Nota-se que os valores obtidos nunca são menores que $80 \%$, sendo que aqueles relativos aos materiais provenientes da amostra gem realizada no local $1 /$ indicam materiais de qualidade um pouco melhor que os valores referentes aos materiais do local l. Este fato jä havia sido verificado por ensaios de ciclagem, e sua explicação jä foi exposta,mas que todavia não chega a se constituir numa indicação de que o material se- 
ja consideravelmente muito melhor que o do local 1. Pode-se verificar que os resultados obtidos com os arenitos do local I estão acima dos $90 \%$, o que demonstra o comportamento exposto.

Outra evidéncia a partir dos ensaios, ê que os resultados da resistência ao impacto Treton sofre pouca influência do fato de o material ter sido ensaiado "in natura", apôs ciclagem acelerada com extrator Soxhlet ou ägua-estufa.

Ruiz (1966) tabulou valores de ensaios realizados com värios tipos de rochas do estado de São Paulo, incluindo gnaisses, granitos, granulitos, e algumas sedimentares como calcärios, dolomitos e inclusive arenito Botucatu. Desse trabalho pode-se verificar que os valores de resistência ao impacto para tais rochas estä sempre abaixo de $40 \%$. O arenito Botucatu apresenta resistencia da ordem de $23,1 \%$. Através dessa comparação, com provamos o comportamento insatisfatório dos Arenitos Caiuä ao impacto Treton, considerando-se as especificações adotadas nesta sërie de ensaios.

\section{Resistëncia à Abrasão Los Angeles}

A tabela nümero 53, refere-se aos ensaios realizados com amostras provenientes de amostragem feita no local 11 , tendo sido efetuados 2 ensaios com amostras "in natura" e 2 com amostras preliminarmente submetidas a ciclagem acelerada água-estufa.

A tabela número 53, refere-se aos ensaios com amostras do local 1 , realizados na condição "in natura".

Material: Arenito Caiuä limonítico

Procedência: local 11

Tabela 53

Resistência à abrasão Los Angeles do Arenito Caiuä

\begin{tabular}{lccc}
\hline & $P_{i}$ & $P_{f}$ & $A$ \\
Amostra 1 & 10081 & 6559 & $34,94 \quad($ a) \\
Amostra 2 & 10081 & 1905 & 81,10 (b) \\
Amostra 3 & 10078 & 6690 & $33,62($ c) \\
Amostra 4 & 10078 & 2140 & 78,77 (d) \\
\hline
\end{tabular}


Tabela 53 - folha 2

(a) - Resultado após 200 resoluções da carga abrasiva sobre a amostra. Material "in natura".

(b) - Idem após 1000 resoluções. Material "in natura".

(c) - Resultado apös 200 resoluções. Amostras submetidas preliminarmente a 4 meses de ciclagem acelerada ägua-estufa.

(d) - Resultado após 1000 resoluções. Amostras submetidas preliminarmente a 4 meses de ciclagem acelerada ägua-estufa.

Tabela 54

Resistência ã abrasão Los Angeles do Arenito Caiuã

Material: Arenito Caiuä limonitico

Proveniência: local I

\begin{tabular}{lccc}
\hline & $P_{i}$ & $P_{f}$ & $A$ \\
Amostra 1 & 10140 & 53 & $99,48(a)$ \\
Amostra 2 & 10140 & 0,0 & $100,00(\mathrm{~b})$ \\
\hline
\end{tabular}

(a) - Resultado apōs 200 revoluções. Material "in natura".

(b) - Resultado após 1000 revoluções. Material "in natura".

\section{Comentärios sobre os ensaios de abrasão Los Angeles}

A exemplo dos ensaios de impacto Treton, os materiais de comportamento satisfatörio nos ensaios de abrasão são aqueles que apresentaram, apös os resultados, baixos valores da relação que quantifica a perda de material durante os referidos ensaios.

Usando ainda os dados oferecidos por Ruiz (1966), podemos verificar que as rochas por ele ensaiadas apresentaram valores de $A$ entre $11,5 \%$ (basalto acidificado de Pirajü) até $62,1 \%$ (granulito de Caraguatatuba), sendo que o arenito Botucatu, da serra do mesmo nome revela valores de $33,9 \%$. 
Analisando as tabelas correspondentes aos ensaios com os Arenitos Caiuä, notamos que aquelas provenientes da amostragem feita no local 11 apresentam resultados dos ensaios á abrasão com grande dispersão. 0 material ensaiado nas condições "in natura" revela que evidentemente o des" gaste é maior de acordo com o nümero de voltas com a carga abrasiva, porém - material ciclado apōs 4 meses apresenta valores que parentemente fazem julgar que a ciclagem näo os teria afetado, mas tão somente o maior número de revoluçães do equipamento tenha o responsävel pelas discrepâncias dos valores.

As amostras provenientes do local 1 apresentaram valores muito mais altos que os do ponto de amostragem anterior, e muito provavelmente devido às mesmas razões que influenciaram os diferentes valores obtidos no ensaio de impacto Treton.

\section{Ensaios de compressão simples axial e deformabilidade}

As amostras escolhidas para tais ensalos foram aquelas pertencen tes ao conjunto 3 de amostras. Foram recolhidas principalmente pröximas à cota 228 e pröximas ao limite dos diferentes tipos de arenitos: com cimento limonitico e com cimento limonitico e carbonätico.

De uma maneira geral, os corpos de prova ensaiados o foram segun do 2 a 3 ciclos de carga-descarga, definidos em 20,40 e $60 \mathrm{~kg} / \mathrm{cm}^{2}$ de tensão normal, e em seguida carregadas até a ruptura. Para algumas das amos tras foi omitido o 39 ciclo, jä que fol avallada com muito baixa e resistência à compressão das mesmas. A velocidade de aplicação das cargas foi aproximadamente igual a $10 \mathrm{~kg} / \mathrm{cm}^{2} / \mathrm{min}$.

Para alguns corpos de prova foram respeitados tempos de espera de 10 minutos somente no ültimo ciclo. Para outros, esse tempo foi conside rado no final das cargas e das descargas para todos os ciclos.

Essa sistemática visou a detecçăo de eventuais comportamentos anelästicos do material ensalado (Mello Mendes, 1968).

As deformações foram medidas para cada intervalo de $10 \mathrm{~kg} / \mathrm{cm}^{2}$ de carga.

As amostras foram ensaiadas secas, tendo sido depositadas na câmara sêca apös permanência de 24 horas em estufa à temperatura de $100 \pm$ $10^{\circ} \mathrm{C}$. Esta imposição foi observada devido à constatação da decomposição 
completa da maioria das amostras em presença de ägua, facilmente verificável nos ensaios de ciclagem ägua-estufa. Anteriormente ã referida secagem, elas estiveram estocadas durante um periodo de 1 ano e meio.

os valores do Mödulo de Elasticidade Secante $\left(E_{s}\right)$, foram obtidos a partir da média aritmética dos valores correspondentes á cada ciclo, e utilizando os pares de valores correspondentes aos pontos de início e tërmino de cada ciclo. Para algumas amostras, foram desprezados os ciclos com tensão de $20 \mathrm{~kg} / \mathrm{cm}^{2}$ no cälculo do $E_{s}$, pelo fato destes ciclos se destinarem a promover uma melhor adaptaçäo do corpo de prova ao equipamento de aplicação das cargas.

Verificou-se que a velocidade de carregamento utilizada nos ensaios esteve abaixo de certos limites dentro dos quais a influencia da mes ma pode ser considerada desprezivel. Isto conduz a que se possam esperar valores mais altos, seja para orup como para $E_{S}$ "

Na tabela nümero 55 , estão relacionadas algumas características das amostras e dos ensaios realizados.

\section{Comentärios quanto ã compressão simples e deformabili idade}

As rochas comportam-se, quando ã deformação, geralmente de uma maneira anelästica. Quer dizer que somente dentro de determinados intervalos de carregamento e desde que se admitam certas aproximações é que o seu comportamento é caracteristicamente elästico, ou seja, obedece à lei de Hooke que estabelece a proporcionalidade entre as tensões e as deformações.

Assim è que, quando se ensaiam corpos de prova de rocha, os resultados podem ser representados por grä́icos como o da figura nümero 27 . Nele verifica-se que ë possivel constatar-se a proporcionalidade entre as tensöes e as deformaçöes apenas numa primeira região de carregamento, ou seja para tensóes variando desde 0 (zero) atë um determinado valor $\sigma_{B}$.

Ainda assim, a proporcionalidade referida ê verificada apenas no carregamento, pois, tão logo se inicia a descarga, apös ter-se atingido um determinado valor $\sigma_{A}$ da tensão, aquela não se realiza numa linha que coincida com a do carregamento original $(O A)$, mas sim segundo a $A A^{\prime}$, que configura uma deformação residual $O A^{\prime}$, a qual poderá anular-se após algum tempo.

Se atingida a tensão $\sigma_{A}$ ela for mantida por certo tempo, a defor 


\section{Tabela 55}

Ensaios de compressão simples e deformabilidade dados dos corpos de prova ensaiados

\begin{tabular}{|c|c|c|c|c|c|c|c|c|}
\hline $\begin{array}{l}\text { Amostra } \\
\text { numero } \\
\text { Sondagem } \\
\text { nümero }\end{array}$ & $\begin{array}{l}\text { Corpo de } \\
\text { Prova } \\
\text { nümero }\end{array}$ & $\begin{array}{c}\text { Profundida } \\
\text { de }(\mathrm{m})\end{array}$ & $\begin{array}{l}\text { Massa Especi } \\
\text { fica Aparen- } \\
\text { te Seca Mëdia } \\
Y_{\text {as }}\left(\mathrm{g} / \mathrm{cm}^{3}\right)\end{array}$ & $\begin{array}{l}\text { Porosidade } \\
\text { Aparente } \\
\text { Mëdia } \\
\text { Pa }(\%)\end{array}$ & $\begin{array}{l}\text { Absorção } \\
\text { D'Âgua } \\
\text { Mëdia } \\
\text { Ab }(\%)\end{array}$ & $\begin{array}{l}\text { Mödulo de Elasticida- } \\
\text { de Secante (Es) } \\
\qquad\left(\mathrm{Kg} / \mathrm{cm}^{2}\right)\end{array}$ & $\begin{array}{l}\text { Tensão de } \\
\text { Ruptura } \\
\left(\sigma_{\text {rup }}\right) \\
\left(\mathrm{Kg} / \mathrm{cm}^{2}\right)\end{array}$ & $\frac{E_{40}}{\sigma_{\text {rup }}}$ \\
\hline 16 & & 13,42 & & & & $E_{1}=$ & & \\
\hline (D) & & $a$ & 1,84 & 26,82 & 14,57 & $E_{2}=66.000$ & 69 & 956 \\
\hline$S R-3$ & & 14,20 & & & & $E_{3}=$ & & \\
\hline 18 & & 24,88 & & & & $E_{1}=62.300$ & & \\
\hline (D) & & $a$ & - & - & - & $E_{2}=63.500$ & 129 & 492 \\
\hline$S R-3$ & & 25,04 & & & & $E_{3}=72.000$ & & \\
\hline 19 & & 27,65 & & & & $E_{1}=20.450$ & & \\
\hline (b) & & a & 2,14 & 25,63 & 11,95 & $E_{2}=18.650$ & 128 & 145 \\
\hline$S R-3$ & & 27,87 & & & & $E_{3}=18.250$ & & \\
\hline 20 & & 32,40 & & & & $E_{1}=$ & & \\
\hline $\begin{array}{c}(1 C) \\
S R-3\end{array}$ & & $\begin{array}{c}a \\
34,54\end{array}$ & 2,19 & 15,22 & 6,94 & $\begin{array}{l}E_{2}=115.940 \\
E_{3}=113.000\end{array}$ & 237 & 489 \\
\hline 22 & & 17,30 & & & & $E_{1}=48.300$ & & \\
\hline (D) & & a & 1,74 & 26,53 & 15,56 & $E_{2}=47.900$ & 113 & 423 \\
\hline$S R-4$ & & 18,65 & & & & $E_{3}=56.350$ & & \\
\hline
\end{tabular}


Tabela 55 - folha 2

\begin{tabular}{|c|c|c|c|c|c|c|c|c|}
\hline $\begin{array}{l}\text { Amostra } \\
\text { número } \\
\text { Sondagem } \\
\text { número }\end{array}$ & $\begin{array}{l}\text { Corpo de } \\
\text { Prova } \\
\text { nümero }\end{array}$ & $\begin{array}{l}\text { Profundida } \\
\text { de }(m)\end{array}$ & $\begin{array}{l}\text { Yiassa Especí } \\
\text { fica Aparen- } \\
\text { te Seca Mëdia } \\
\gamma_{\text {as }}\left(\mathrm{g} / \mathrm{cm}^{3}\right)\end{array}$ & $\begin{array}{l}\text { Porosidade } \\
\text { Aparente } \\
\text { Mëdia } \\
\text { Pa (\%) }\end{array}$ & $\begin{array}{l}\text { Absorção } \\
\text { D'Âgua } \\
\text { Mëdia } \\
\text { Ab (\%) }\end{array}$ & $\begin{array}{c}\text { Mödulo de Elasticida- } \\
\text { de Secante (Es) } \\
\qquad\left(\mathrm{kg} / \mathrm{cm}^{2}\right)\end{array}$ & $\begin{array}{l}\text { Tensão de } \\
\text { Ruptura } \\
\left(\sigma_{\text {rup }}\right) \\
\left(\mathrm{Kg} / \mathrm{cm}^{2}\right)\end{array}$ & $\frac{E_{40}}{\sigma_{\text {rup }}}$ \\
\hline 23 & & 28,30 & & & & $E_{1}=$ & & \\
\hline (10) & 2 & 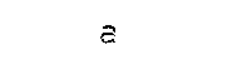 & 1,98 & 21,25 & 10,74 & $E_{2}=27.850$ & 56 & 497 \\
\hline$S R-4$ & & 29,95 & & & & $E_{3}=$ & & \\
\hline 23 & & 28,30 & & & & $E_{1}=$ & & \\
\hline (1) & $2 A$ & $a$ & - & - & - & $E_{2}=31.800$ & 60 & 530 \\
\hline$S R-4$ & & 29,95 & & & & $E_{3}=$ & & \\
\hline 23 & & 28,30 & & & & $E_{1}=$ & & \\
\hline 10 & $2 B$ & $a$ & - & - & - & $E_{2}=13.950$ & 77 & 181 \\
\hline$S R-4$ & & 29,95 & & & & $E_{3}=$ & & \\
\hline 25 & & 11,74 & & & & $E_{1}=45.550$ & & \\
\hline (D) & & $a$ & - & - & - & $E_{2}=43.250$ & 96 & 450 \\
\hline$S R-5$ & & 11,90 & & & & $E_{3}=$ & & \\
\hline 26 & & 17,36 & & & & $E_{1}=$ & & \\
\hline (b) & & $a$ & 1,68 & 34,23 & 20,46 & $E_{2}=71.800$ & 91 & 789 \\
\hline$S R-5$ & & 18,62 & & & & $E_{3}=67.500$ & & \\
\hline
\end{tabular}


Tabela 55 - folha 3

\begin{tabular}{|c|c|c|c|c|c|c|c|c|}
\hline $\begin{array}{l}\text { Amostra } \\
\text { nümero } \\
\text { Sondagem } \\
\text { nümero }\end{array}$ & $\begin{array}{l}\text { Corpo de } \\
\text { Prova } \\
\text { nümero }\end{array}$ & $\begin{array}{l}\text { Profundida } \\
\text { de }(m)\end{array}$ & $\begin{array}{l}\text { Massa Especí } \\
\text { fica Aparen } \\
\text { te Seca Mëdia } \\
\gamma_{\text {as }}\left(\mathrm{g} / \mathrm{cm}^{3}\right)\end{array}$ & $\begin{array}{l}\text { Porosidade } \\
\text { Aparente } \\
\text { Média } \\
\text { Pa }(\%)\end{array}$ & $\begin{array}{l}\text { Absorção } \\
\text { D'Âgua } \\
\text { Média } \\
\text { Ab }(\%)\end{array}$ & $\begin{array}{c}\text { Mödulo de Elasticida- } \\
\text { de Secanta (Es) } \\
\left(\mathrm{Kg} / \mathrm{cm}^{2}\right)\end{array}$ & $\begin{array}{l}\text { Tensão de } \\
\text { Ruptura } \\
\left(\sigma_{\text {rup }}\right) \\
\left(\mathrm{Kg} / \mathrm{cm}^{2}\right)\end{array}$ & $\frac{E_{40}}{\sigma_{\text {rup }}}$ \\
\hline 27 & & 20,91 & & & & $E_{1}=$ & & \\
\hline$\underset{S R-5}{(10)}$ & 2 & $\begin{array}{c}a \\
22,20\end{array}$ & - & - & - & $\begin{array}{l}E_{2}=11.000 \\
E_{3}=\end{array}$ & 88 & 125 \\
\hline$\underset{S R-5}{27}$ & $2 \mathrm{~A}$ & $\begin{array}{l}20,91 \\
a \\
22,20\end{array}$ & - & - & - & $\begin{array}{l}E_{1}=30.160 \\
E_{2}=37.900 \\
E_{3}=44.900\end{array}$ & 120 & 316 \\
\hline$\underset{S R-5}{28}$ & 2 & $\begin{array}{l}31,88 \\
a \\
33,00\end{array}$ & 2,19 & 16,24 & 7,47 & $\begin{array}{l}E_{1}= \\
E_{2}=86.000 \\
E_{3}=74.000\end{array}$ & 249 & 345 \\
\hline$\overbrace{S R-5}^{28}$ & $2 A$ & $\begin{array}{l}31,88 \\
a \\
33,00\end{array}$ & 2,19 & - & - & $\begin{array}{l}E_{1}= \\
E_{2}=112.360 \\
E_{3}=109.900\end{array}$ & 337 & 333 \\
\hline$\underset{S R-6}{29}$ & & $\begin{array}{c}9,00 \\
a \\
10,20\end{array}$ & 1,80 & 26,68 & 14,78 & $\begin{array}{l}E_{1}=77.200 \\
E_{2}=83.500 \\
E_{3}=82.400\end{array}$ & 140 & 596 \\
\hline
\end{tabular}


Tabela 55 - folha 4

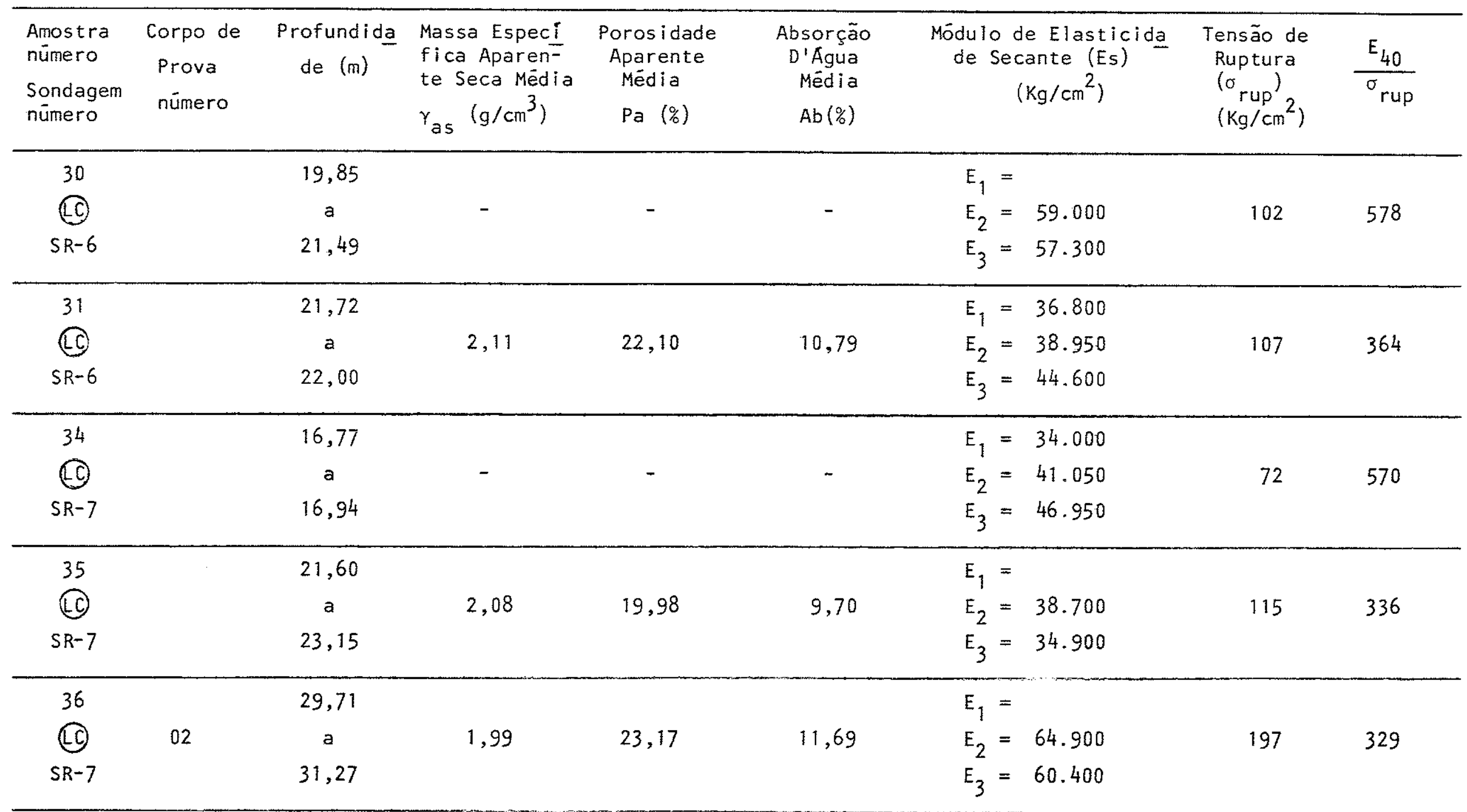


Tabela 55 - follha 5

\begin{tabular}{|c|c|c|c|c|c|c|c|c|}
\hline $\begin{array}{l}\text { Amostra } \\
\text { número } \\
\text { Sondagem } \\
\text { nümero }\end{array}$ & $\begin{array}{l}\text { Corpo de } \\
\text { Prova } \\
\text { numero }\end{array}$ & $\begin{array}{l}\text { Profundida } \\
\text { de }(m)\end{array}$ & $\begin{array}{l}\text { Massa Especí } \\
\text { fica Aparen- } \\
\text { te Seca Média } \\
\gamma_{\text {as }}\left(\mathrm{g} / \mathrm{cm}^{3}\right)\end{array}$ & $\begin{array}{l}\text { Porosidade } \\
\text { Aparente } \\
\text { Mëdia } \\
\text { Pa (\%) }\end{array}$ & $\begin{array}{l}\text { Absorção } \\
\text { D'Aुgua } \\
\text { Mëdia } \\
\text { Ab (\%) }\end{array}$ & $\begin{array}{c}\text { Mödulo de Elasticida- } \\
\text { de Secante (Es) } \\
\left(\mathrm{Kg} / \mathrm{cm}^{2}\right)\end{array}$ & $\begin{array}{l}\text { Tensäo de } \\
\text { Ruptura } \\
\left(\sigma_{\text {rup }}\right) \\
\left(\mathrm{Kg} / \mathrm{cm}^{2}\right)\end{array}$ & $\frac{E_{40}}{\sigma_{\text {rup }}}$ \\
\hline 36 & & 29,71 & & & & $\mathrm{E}_{1}=$ & & \\
\hline LC & $02 \mathrm{~A}$ & $a$ & - & - & - & $E_{2}=55.000$ & 175 & 314 \\
\hline$S R-7$ & & 31,27 & & & & $E_{3}=47.950$ & & \\
\hline 38 & & 28,72 & & & & $E_{1}=$ & & \\
\hline$\overline{L C}$ & & $a$ & 2,34 & 11,96 & 5,11 & $E_{2}=74.350$ & 210 & 354 \\
\hline$S R-8$ & & 30,32 & & & & $E_{3}=66.650$ & & \\
\hline 15 & & 16,42 & & & & $E_{1}=$ & & \\
\hline$E$ & & $\mathrm{a}$ & 1,91 & 22,51 & 11,80 & $E_{2}=87.500$ & 169 & 517 \\
\hline$S R-2$ & & 17,81 & & & & $E_{3}=92.150$ & & \\
\hline 13 & & 9,68 & & & & $E_{1}=$ & & \\
\hline $\mathrm{L}$ & & $a$ & 1,83 & 23,48 & 12,83 & $E_{2}=10.650$ & 54 & 197 \\
\hline$S R-1$ & & 10,67 & & & & $E_{3}=$ & & \\
\hline
\end{tabular}

$E_{1}=$ Mödulo de Elasticidade Secante para $\sigma=20 \mathrm{~kg} / \mathrm{cm}^{2}$.

$E_{2}=$ Mödulo de Elasticidade Secante para $\sigma=40 \mathrm{~kg} / \mathrm{cm}^{2}$.

$E_{3}=$ Mödulo de Elasticidade Secante para $\sigma=60 \mathrm{~kg} / \mathrm{cm}^{2}$.

(D) = Cimento limonitico.

(LC) = Cimento limonítico e carbonātico. 


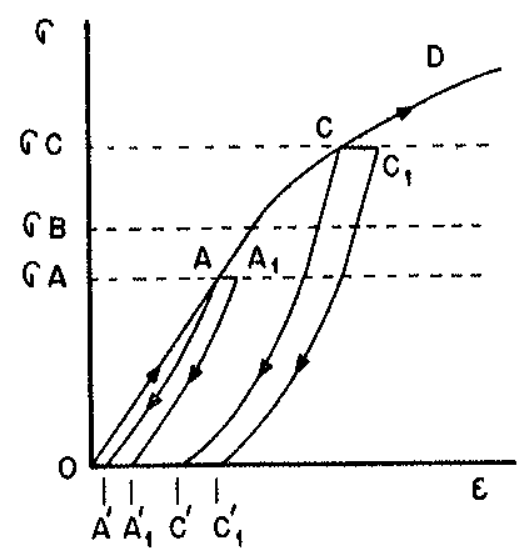

FIG. 27 - CURVAS GENÉRICAS TENSÖES X DEFORMAÇŌES, PARA ROCHAS (APUD MELO MENDES, MOD.). 
mação crescerã concomitantemente, podendo ou não estabilizar-se num determinado valor representado pelo ponto $A_{1}$; se houver ai o descarregamento, a deformação residual correspondente $\vec{e} O A_{1}^{\prime}$ que nem sempre e totalmente anula da.

Apös atingida a tensão $\sigma_{B}$, a curva tensôes-deformações passa a ter sua inclinação diminuida, adquirindo aspectos que cada vez mais descaracterizam a proporcionalidade entre as tensões e as respectivas deformações atê atingir-se a ruptura, no ponto $D$.

Para valores maiores que $\sigma_{B}$, a descarga das tensões como um ponto $C$, e representada por uma linha tanto mais afastada de OAC quanto maior for a tensão $\sigma_{c}$, correspondente a esse ponto. Aumentando-se o valor de $\sigma_{c}$ vão crescer as deformações $c c_{1}$, que passam a ocorrer sob tensão constante, e as fraçōes irreversiveis das deformações residuais oci, que se manifestam no final do descarregamento que se segue a essas deformações sob carga constante. Diz-se que neste momento, foi atingido o limite clástico da ro cha, ou seja, as deformações são permanentes mesmo depois da descarga total, e o material encontramse na fase plästica.

Observa-se, todavia, que o modêlo genërico descrito das curvas representativas da deformabilidade das rochas, pode variar em função de seu estado de sanidade ou das peculariedades intrínsecas de seus padrões estruturais. O fechamento progressivo das descontinuidades e as rupturas das ligações tênues entre os grãos originarão curvas com a concavidade no sentido dos $\sigma$ crescentes. 0 consequente aumento do mödulo de deformabili dade graças à ultrapassagem da fase anterior, e o início da microfissuração posterior com consequente aumento das deformações transversais, alteram a forma da curva, conduzindo a diferentes valores do mỏdulo de deforma bilidade para cada condição citada, e cuja consideração serâ determinada pela particular situação enfrentada.

Levando-se em consideração o que fol exposto e examinando-se os gräficos $\sigma \times$ E resultantes dos ensaios efetuados com os Mrenitos Caiuá (Figuras nümeros 28 a 49), conclui-se:

a) E possivel correlacionar os valores de $\sigma_{\text {rup }}$ com os dos mödu los de deformabilidade secante $\left(E_{s}\right)$ para 20,40 e $60 \mathrm{~kg} / \mathrm{cm}^{2}$. De uma manei ra geral, quanto maior as tensões de ruptura $\left(\sigma_{\text {rup }}\right)$, tanto maiores os $E_{S}$. Ocorrem, no entanto, excessões, como no cado das amostras $7,12,16$ e 20 , para as quais, altos valores de $\sigma_{\text {rup }}$ correspondem $\mathrm{E}_{\mathrm{s}}$ menores ou por volta de $50.000 \mathrm{~kg} / \mathrm{cm}^{2}$. 


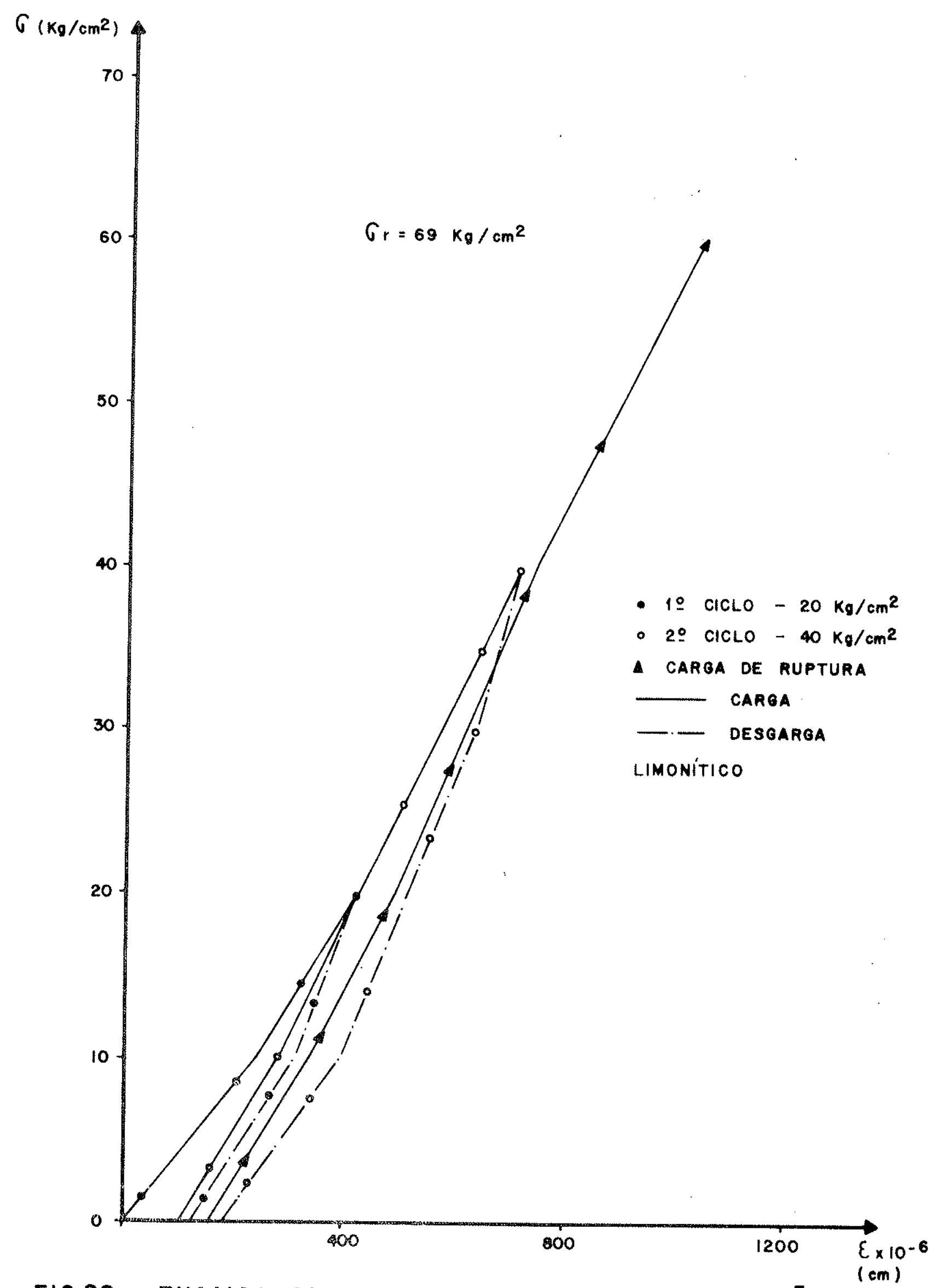

FIG.28 - ENSAIOS DE DEFORMABLIDADE E COMPRESSĀO SIMPLES COM ARENITO CAIUÁ - AMOSTRA NE 16 


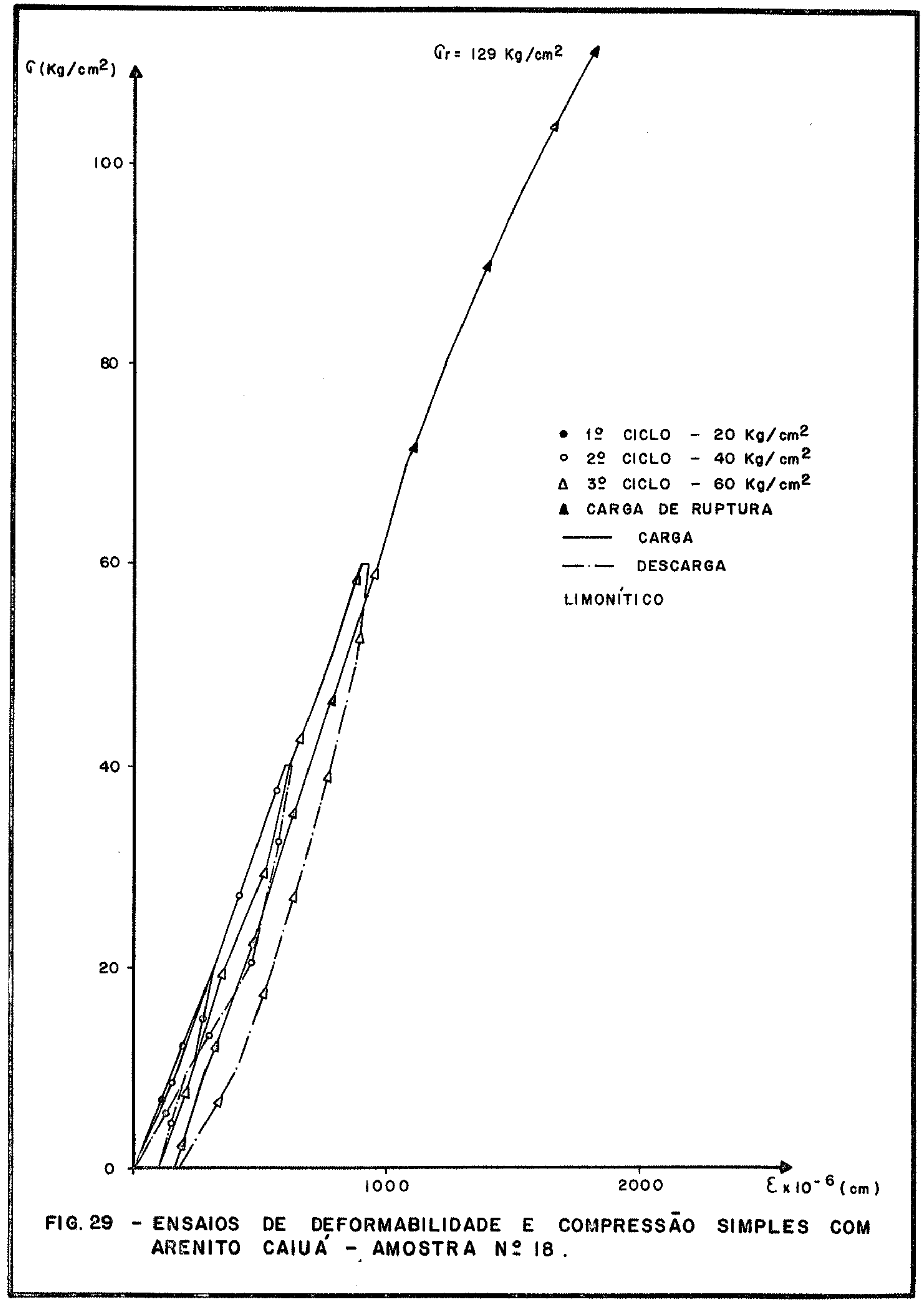




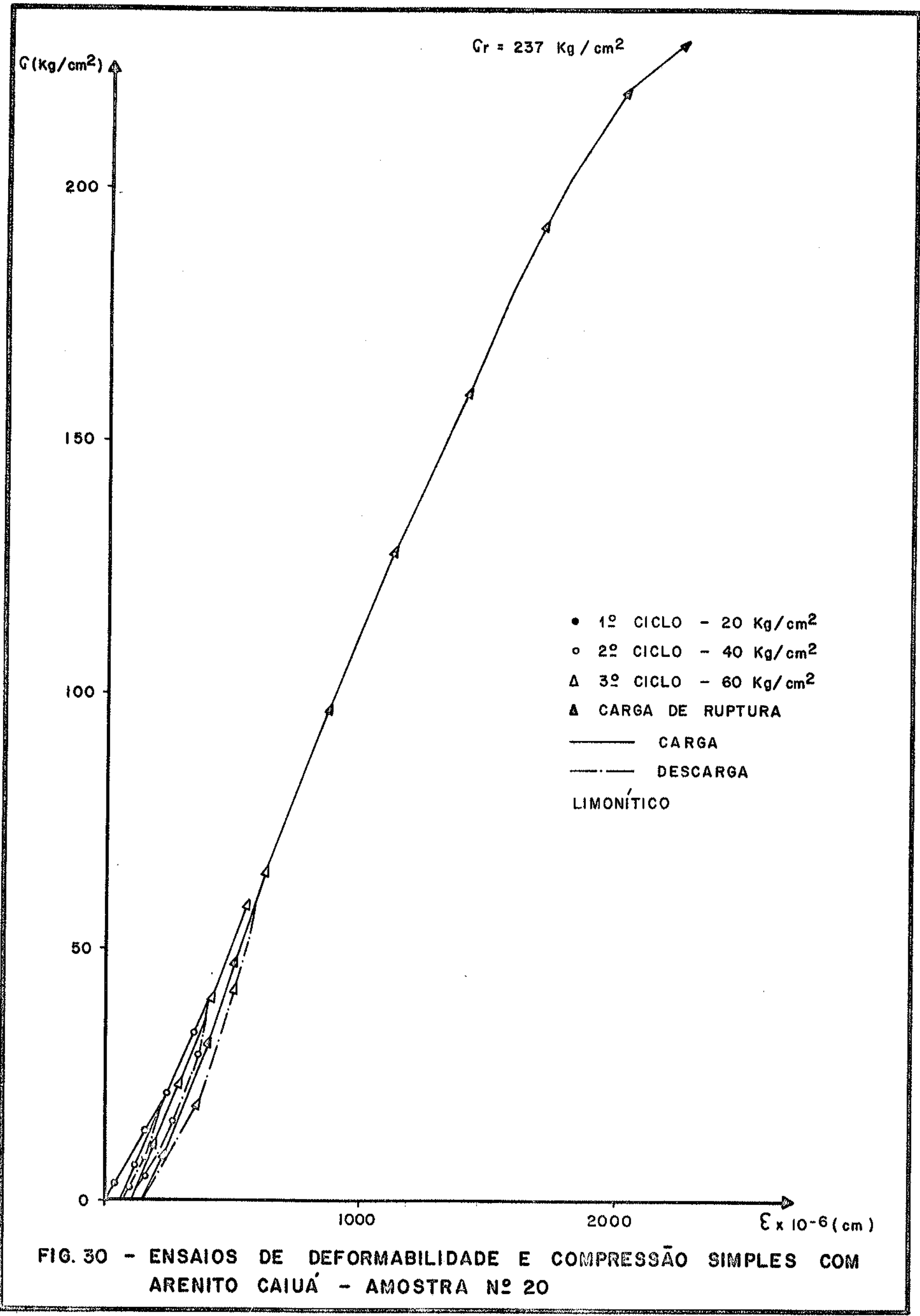




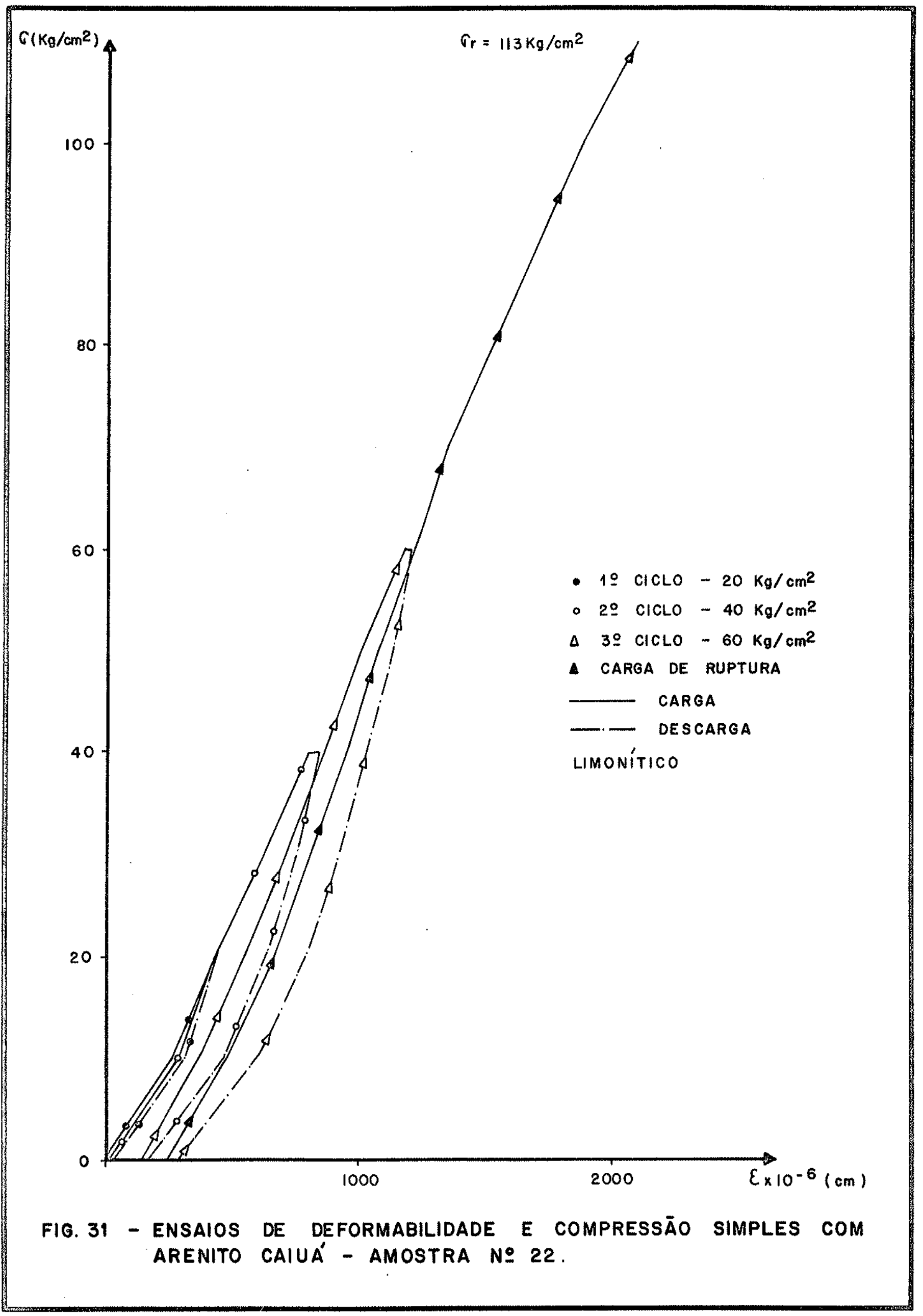




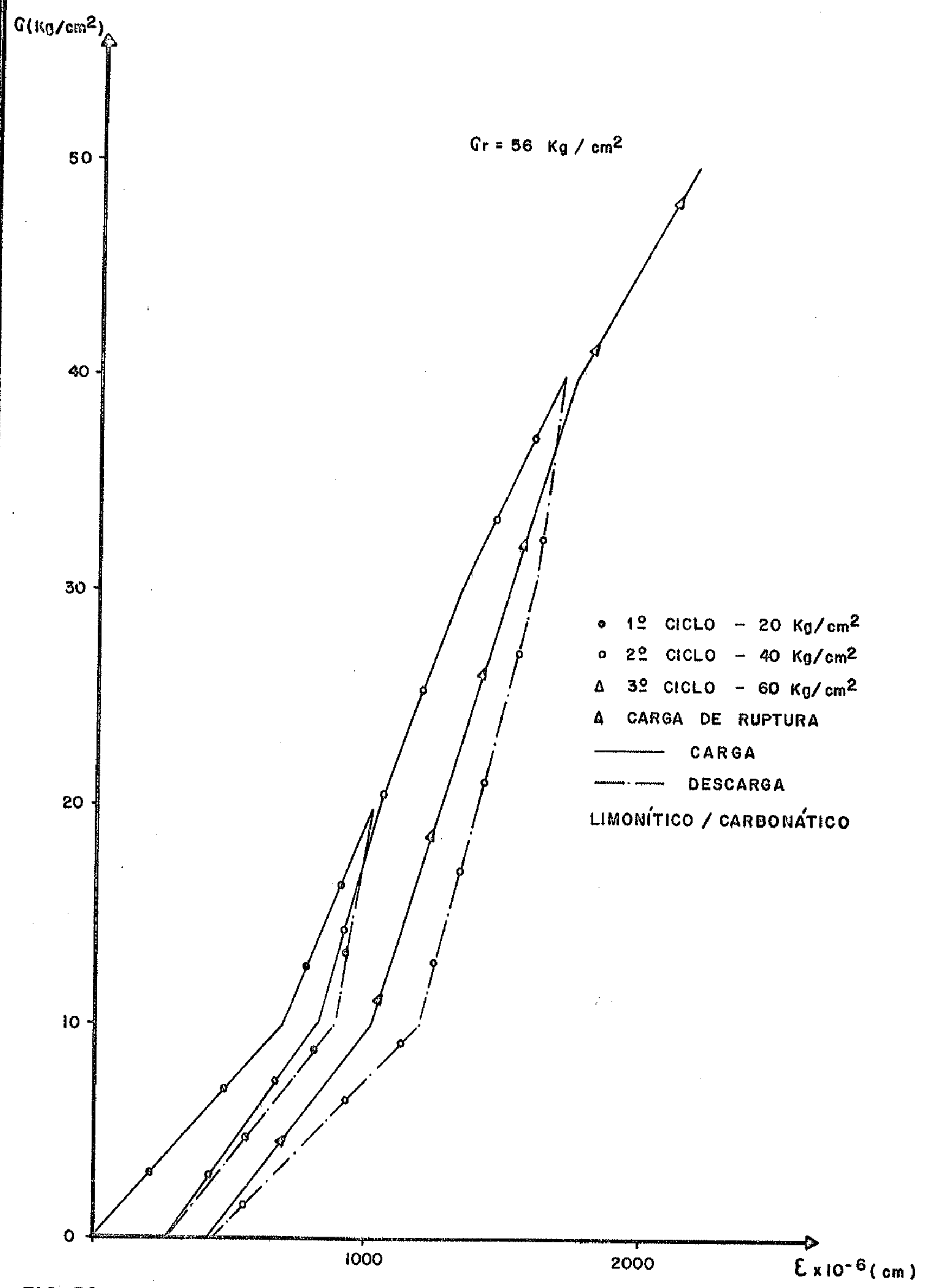

FIG. 32 - ENSAIOS DE DEFORMABILIDADE E COMPRESSĀO SIMPLES COM ARENITO CAIUA' - AMOSTRA NO 23, CORPO DE PROVA NO 2 


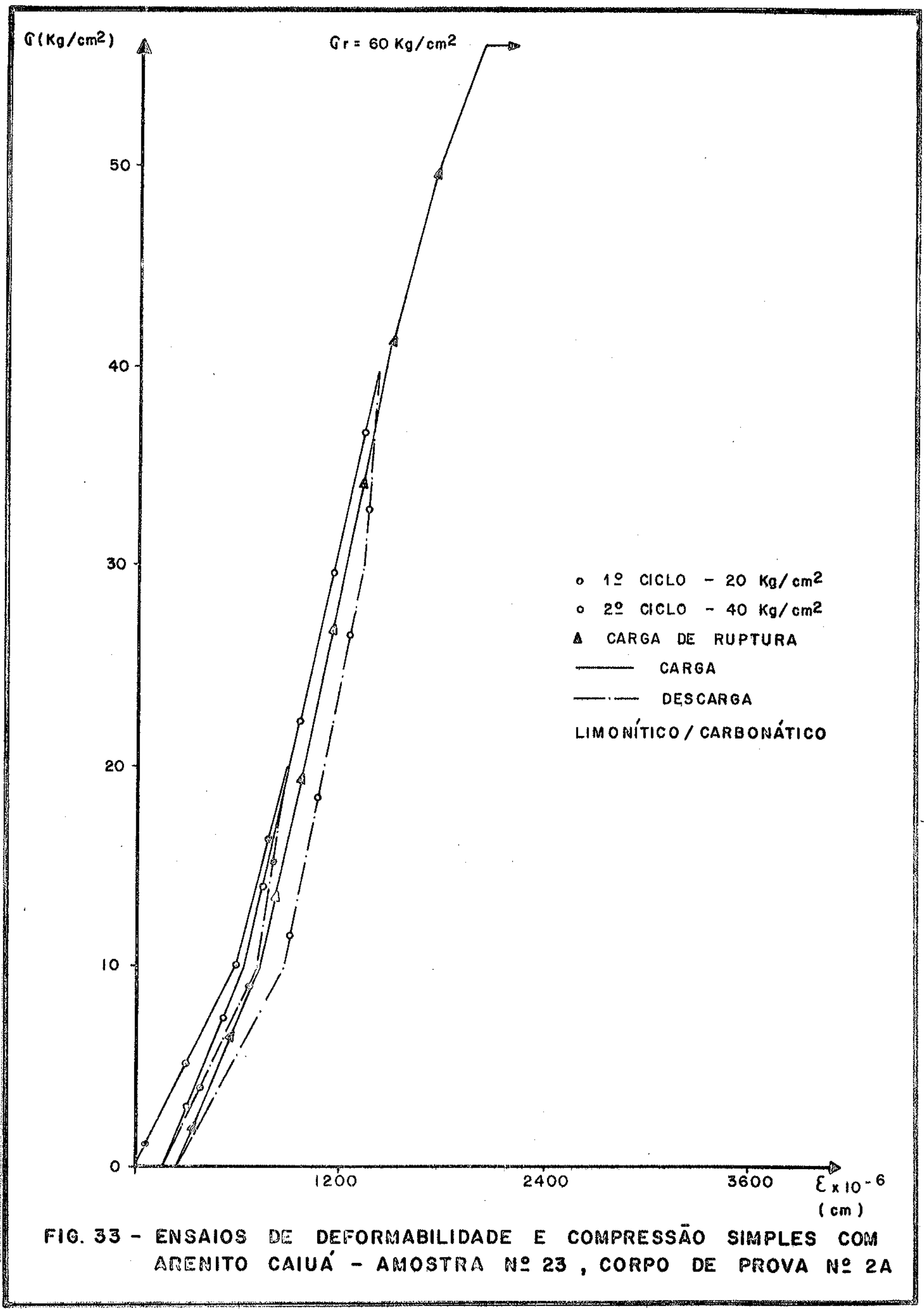




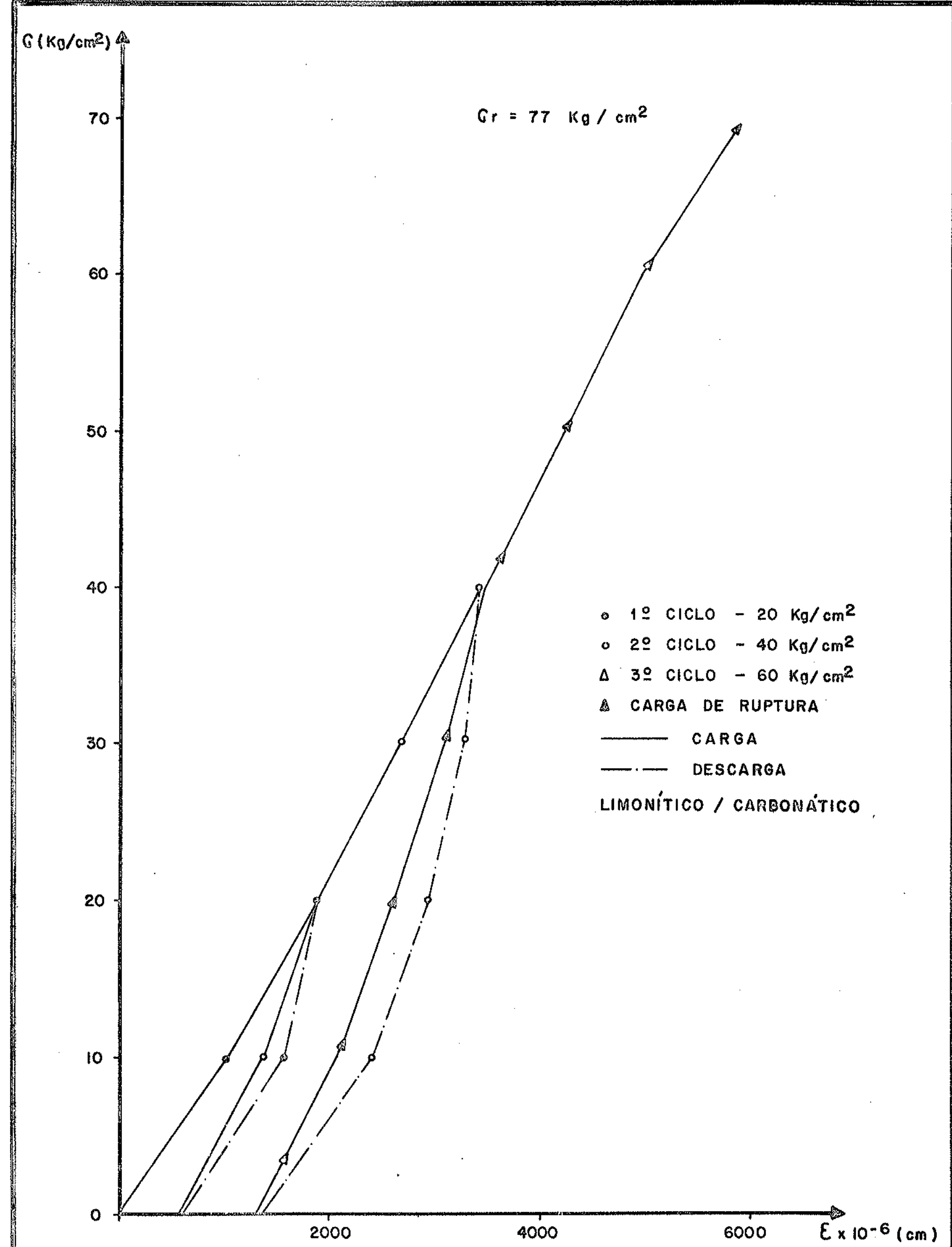

FiG. 39 - ENSAIOS DE DEFORMABILIDADE E COMPRESSĀO SIMPLES COM ARENITO CAIUÁ - AMOSTRA NN 23, CORPO DE PROVA NO $2 B$ 


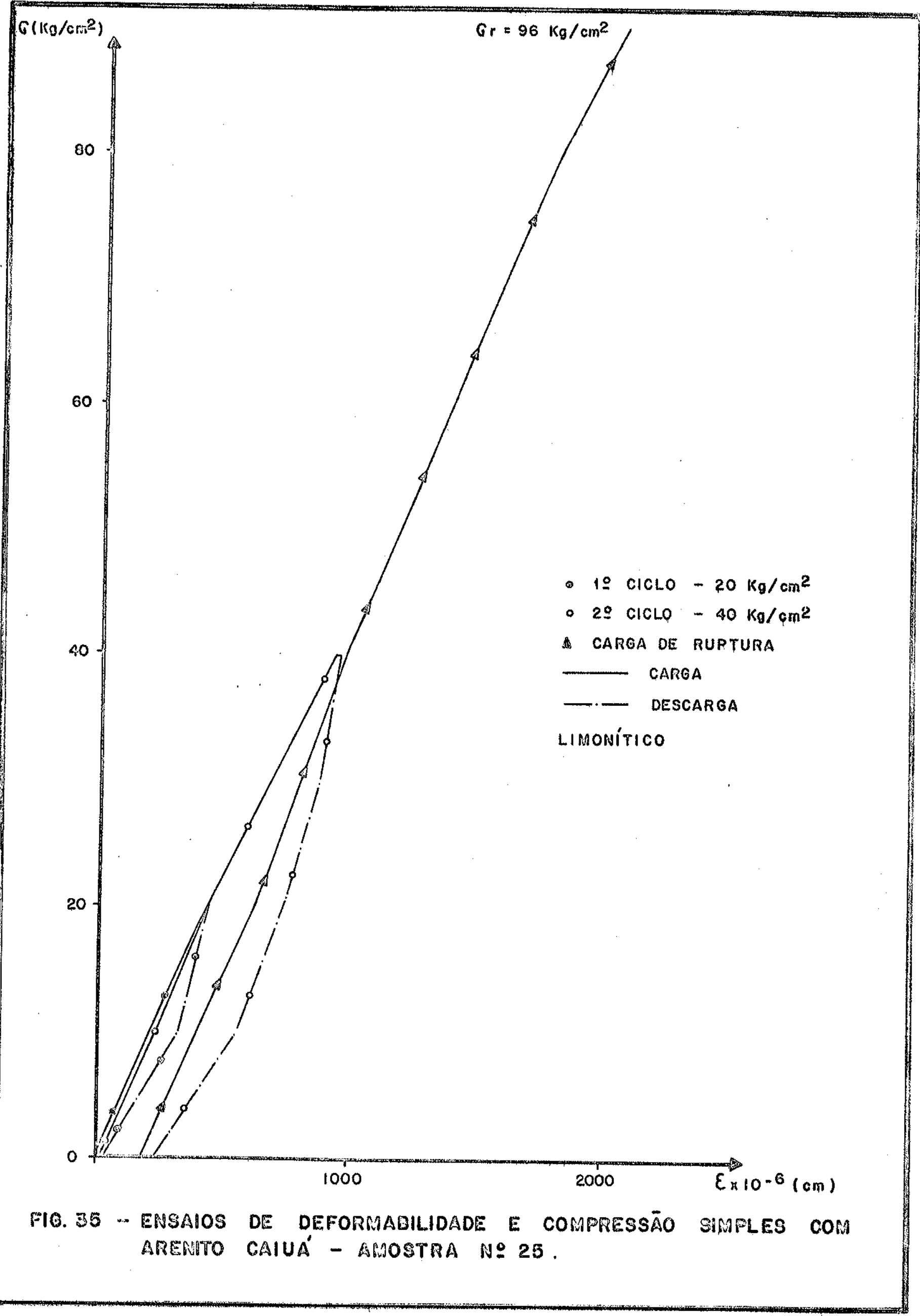


$G\left(\mathrm{~kg} / \mathrm{cm}^{2}\right)$

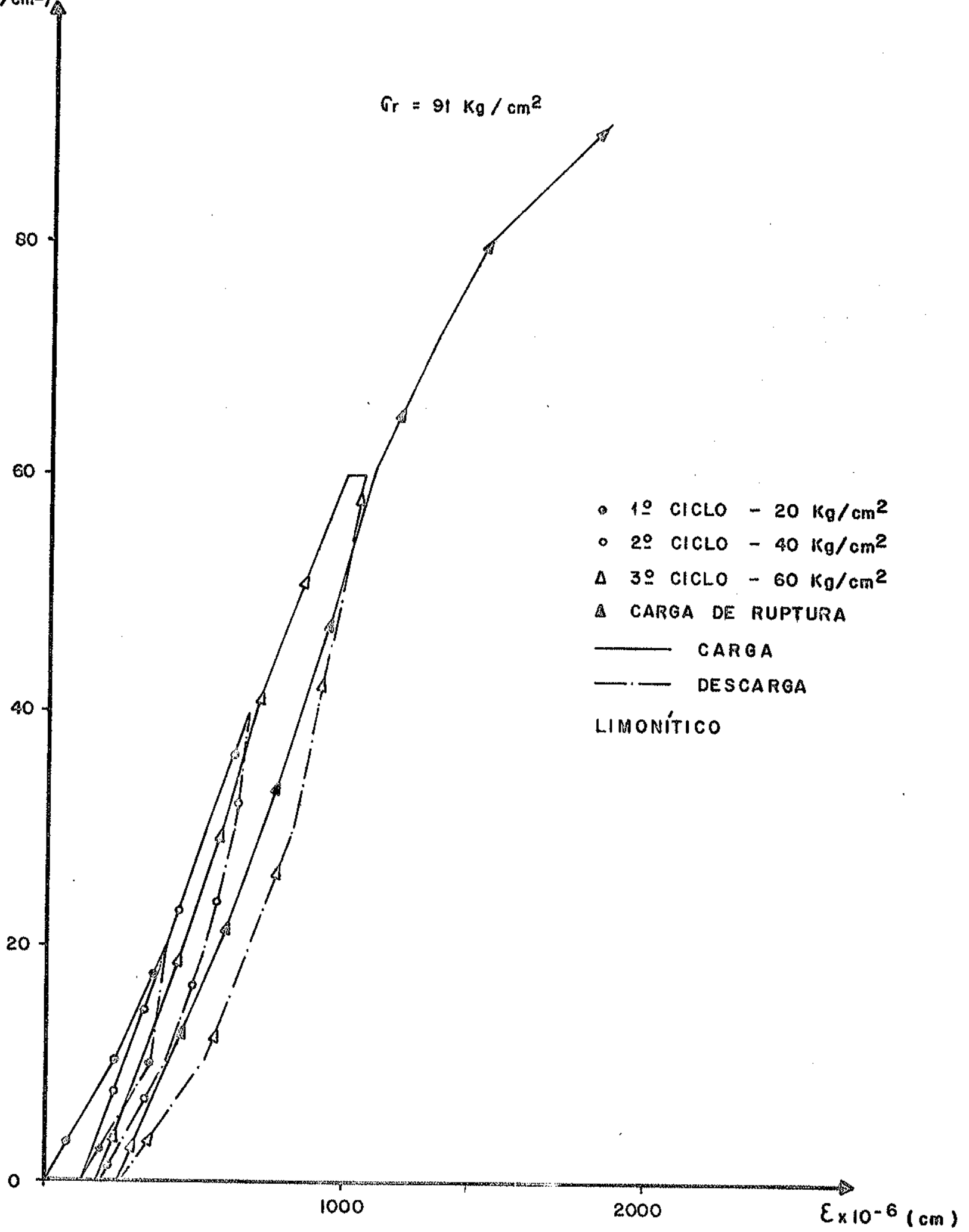

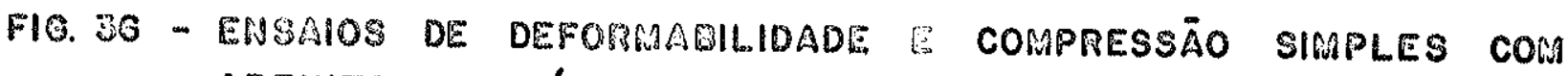
ARERITO CAIUA' - AMOSTRA HO 26. 


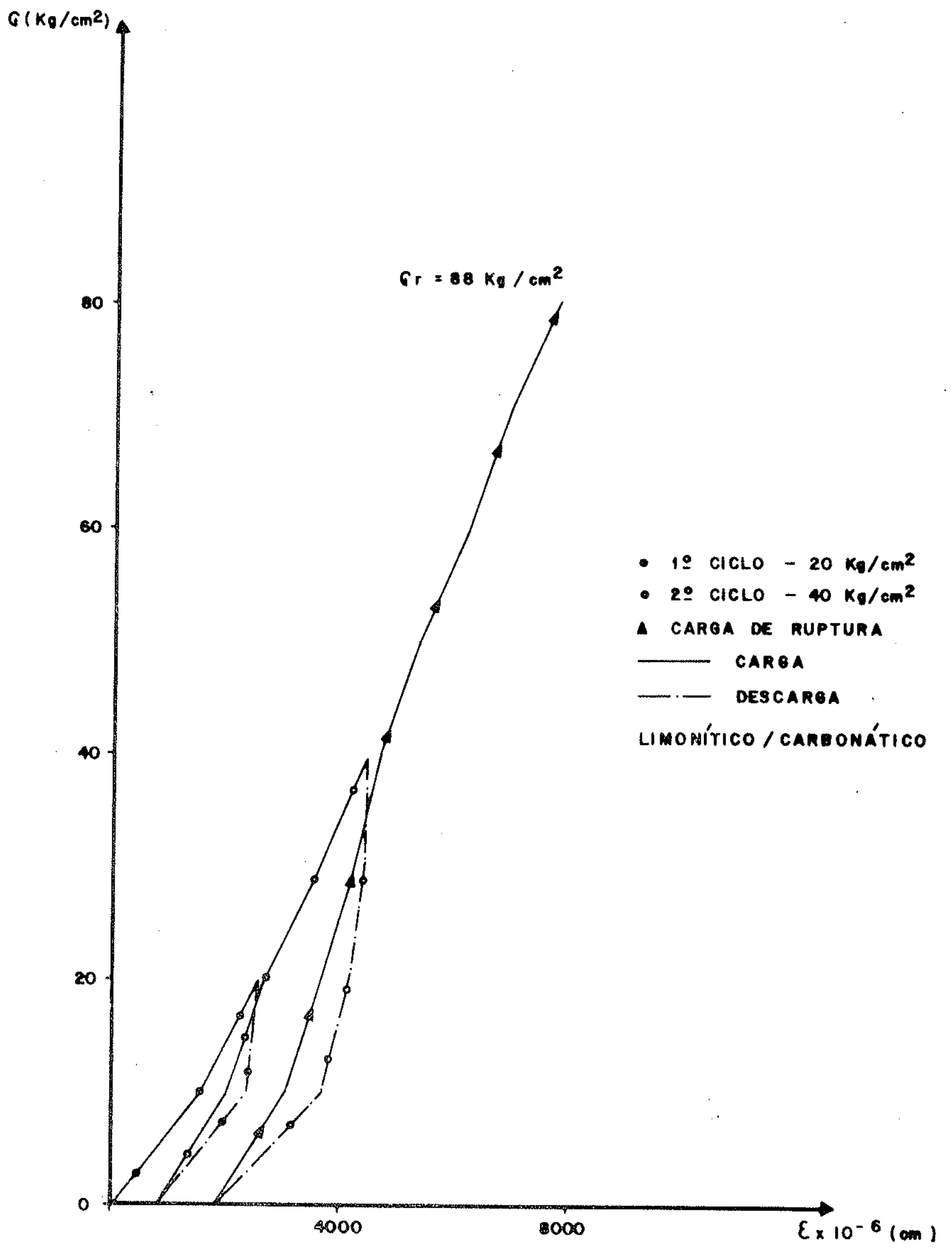

FI6.37 - EHSAIOS OE DEFOMAATLIDADE E COMPRESSĀO SIMPLES CON ARENITO CAIUÁ - AMOSTRA NE 27 , CORPO DE PROVA hE 2 


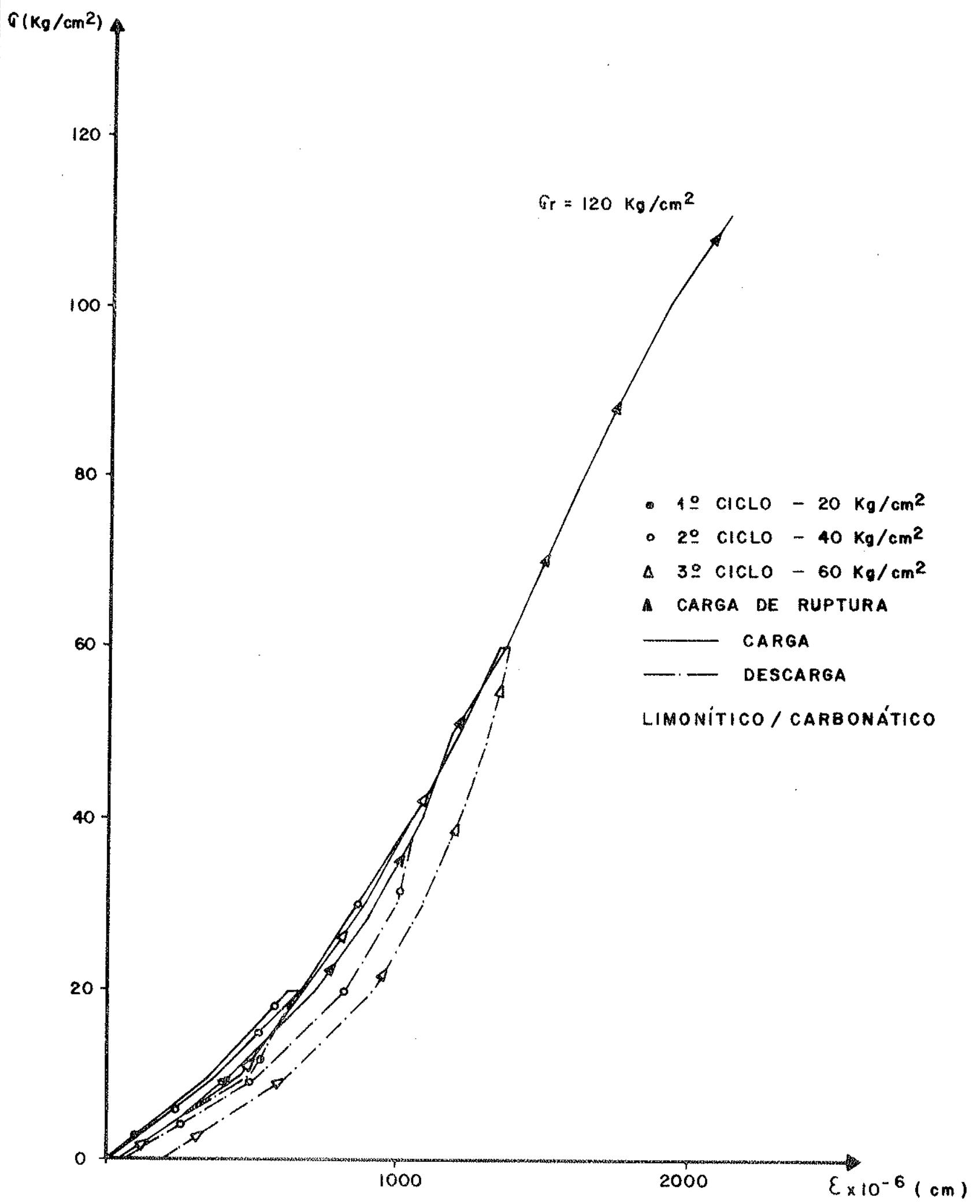

FIG. 38 - ENSAIOS DE DEFORMABLIDADE E COAPRESSĀO SIMPLES COM ARENITO CAIUA - AMOSTRA N 27 , CORPO DE PROVA NE $2 A$ 


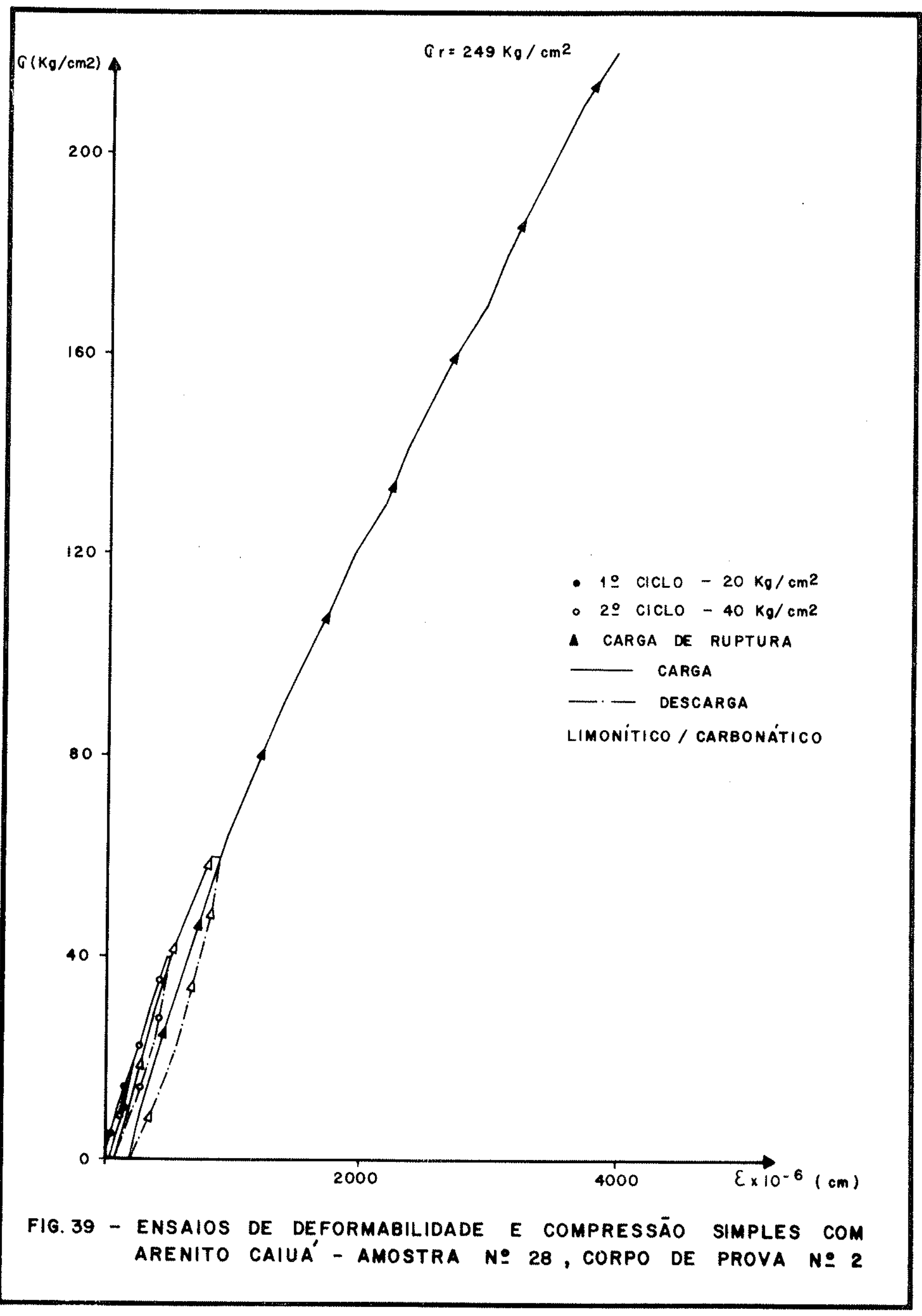




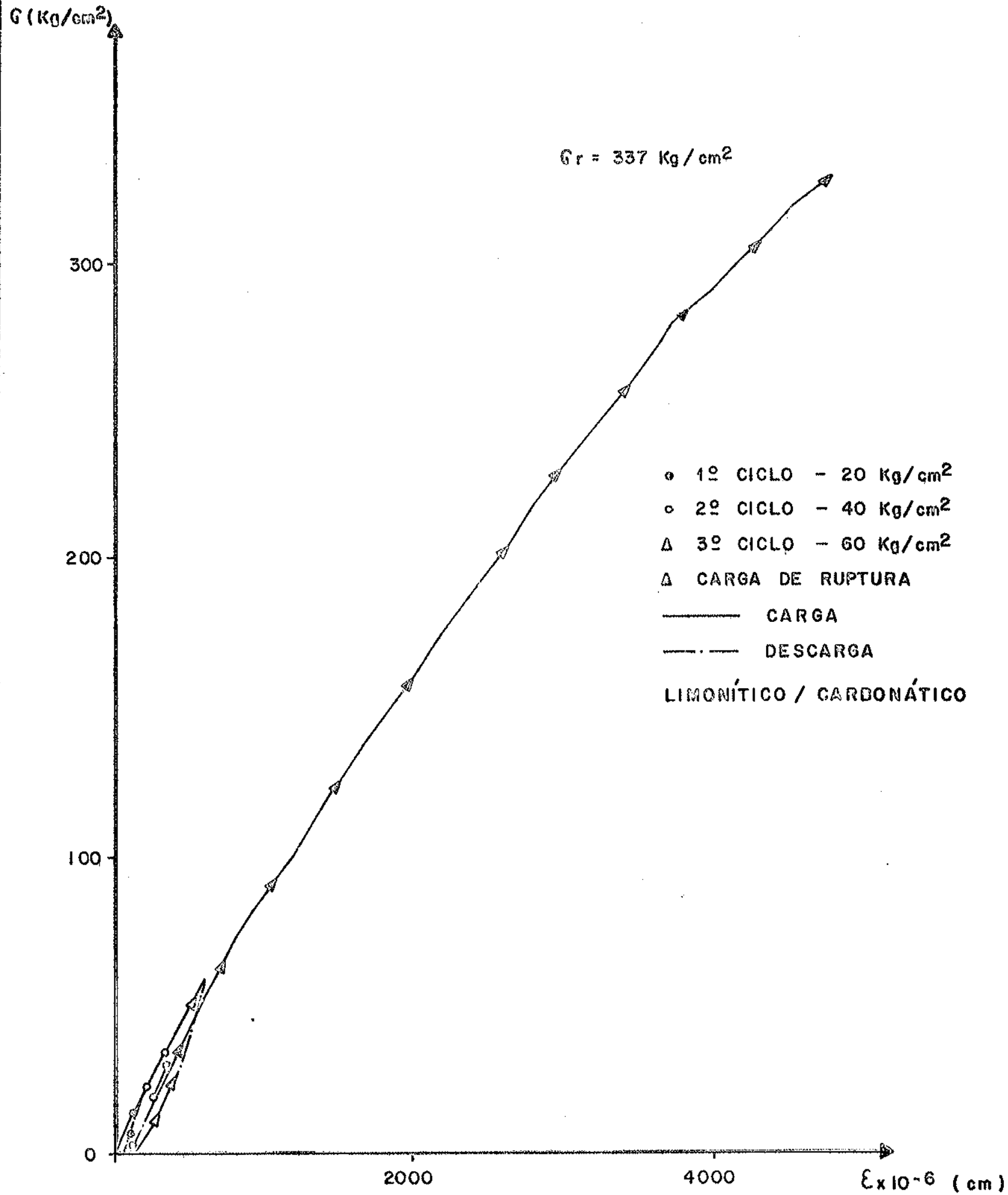

FIG. 40 - ENSAIOS DE DEFORMABILIDADE E COMPRESSĀO SIMPLEES COM ARENITO CAIUÁ - AMOSTRA NE 28 , CORPO DE PROVA NO $2 A$ 


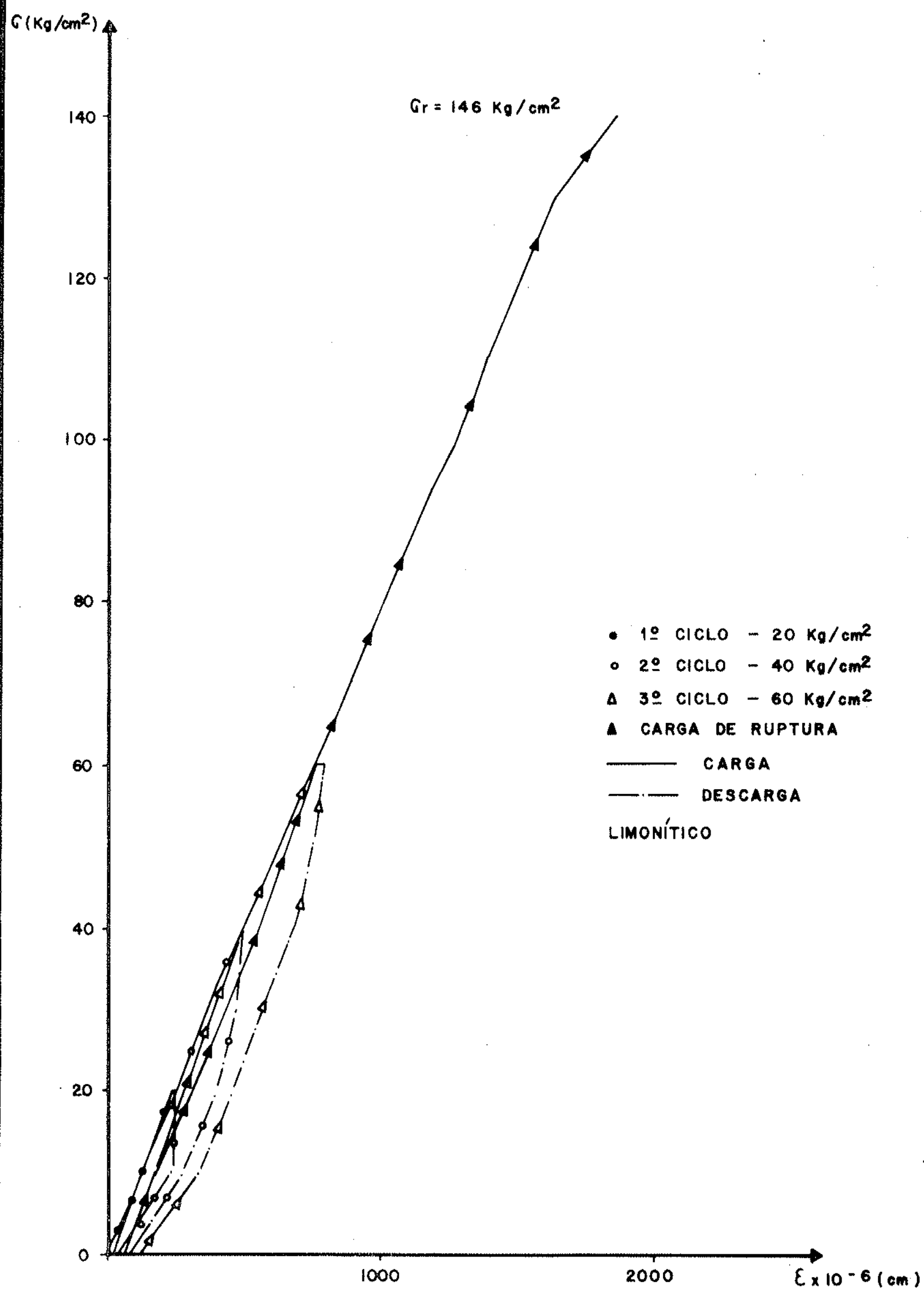

FI6. 44 - ENSAIOS DE DEFORMABILIDADE E COMPRESSĀO SIMPLES COM ARENITO CAIUÁ - AMOSTRA NE 29. 


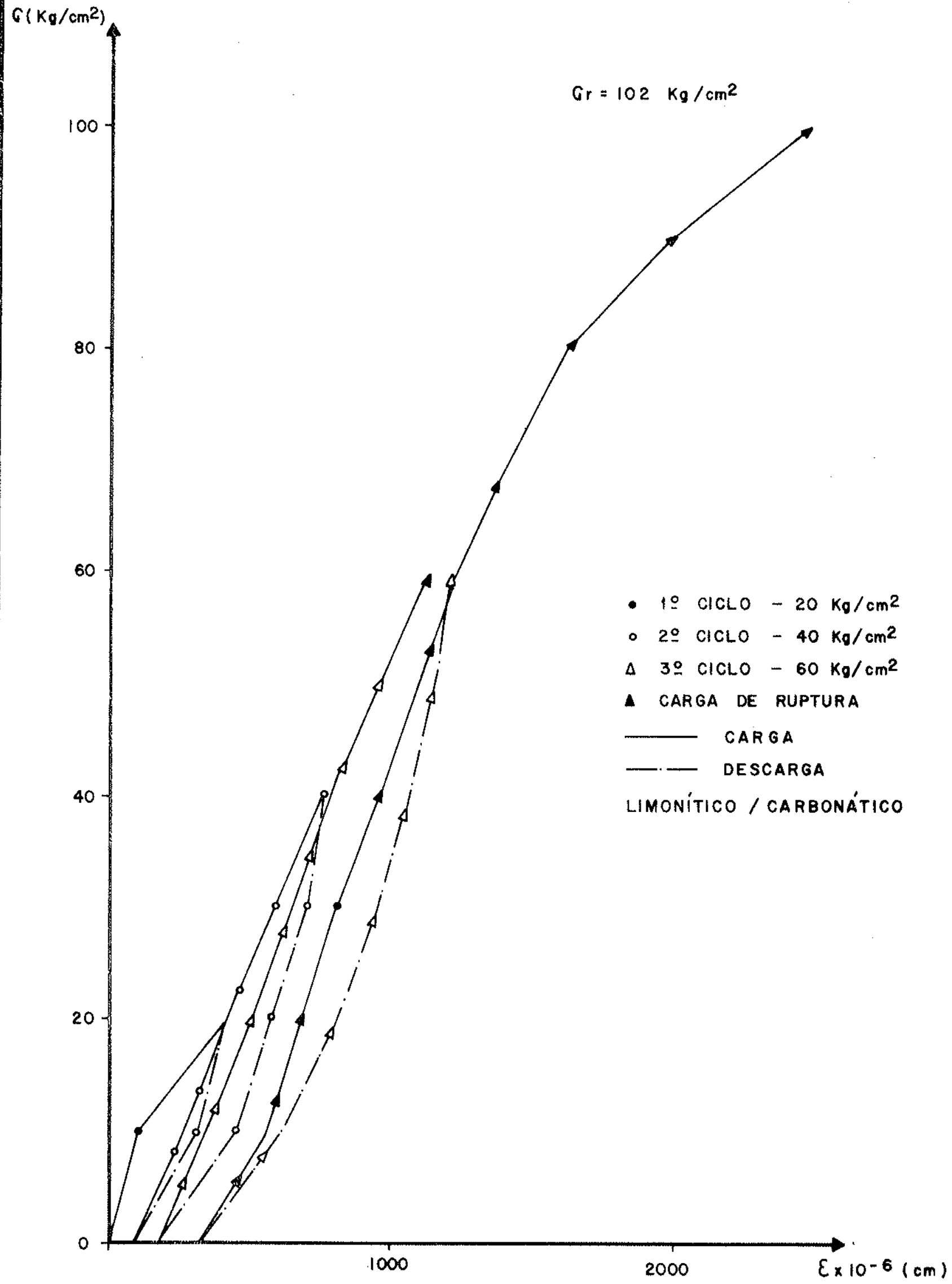

FIG. 42 - ENSAIOS DE DEFORMABILIDADE E COMPRESSĀO SIMPLES COM ARENITO CAIUÁ - AMOSTRA No 30. 


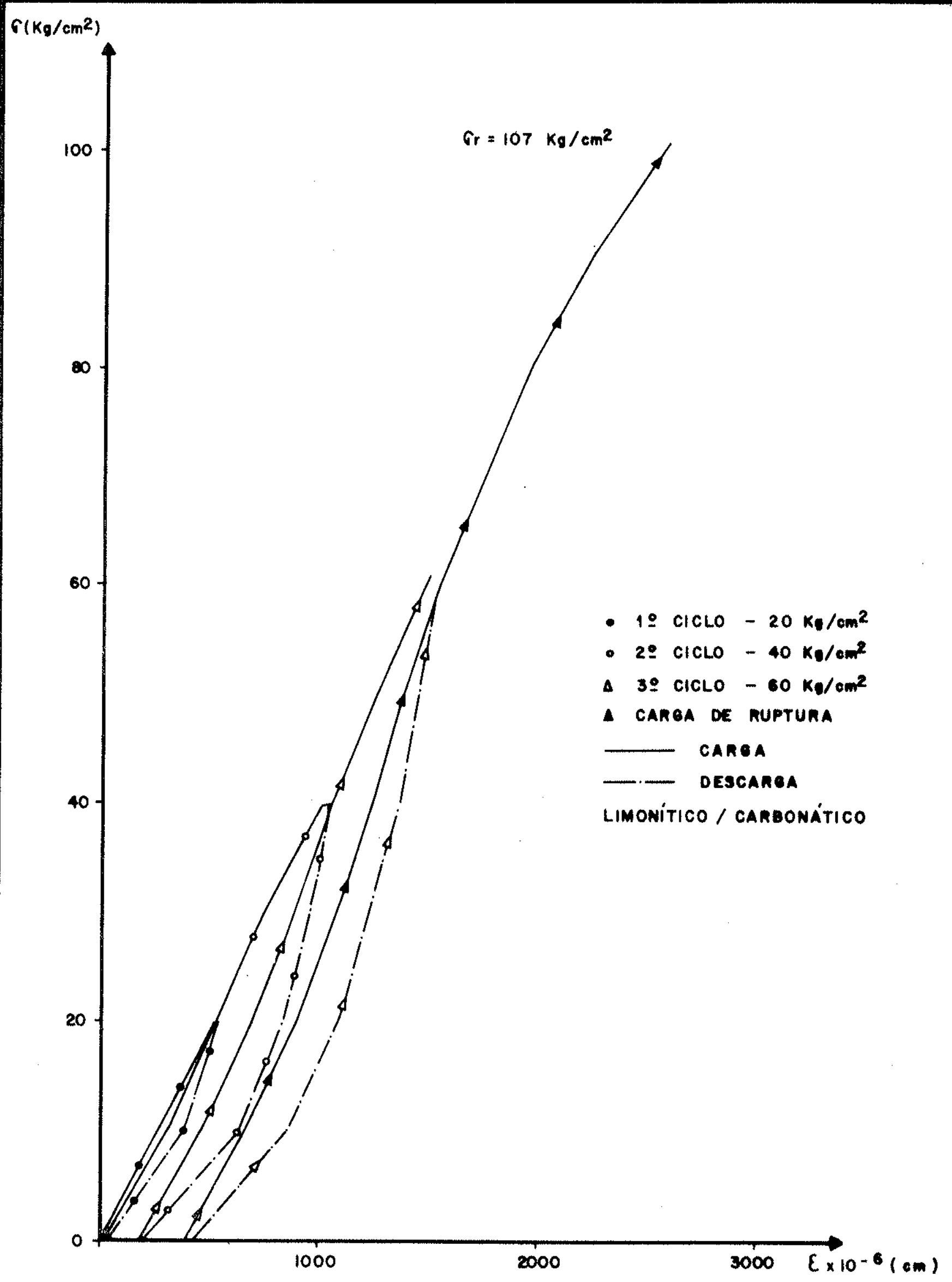

FIG. 43 - ENSAIOS DE DEFORMABILIDADE E COMPRESSÃO SIMPLES COM ARENITO CAIUÁ - AMOSTRA NE 31 


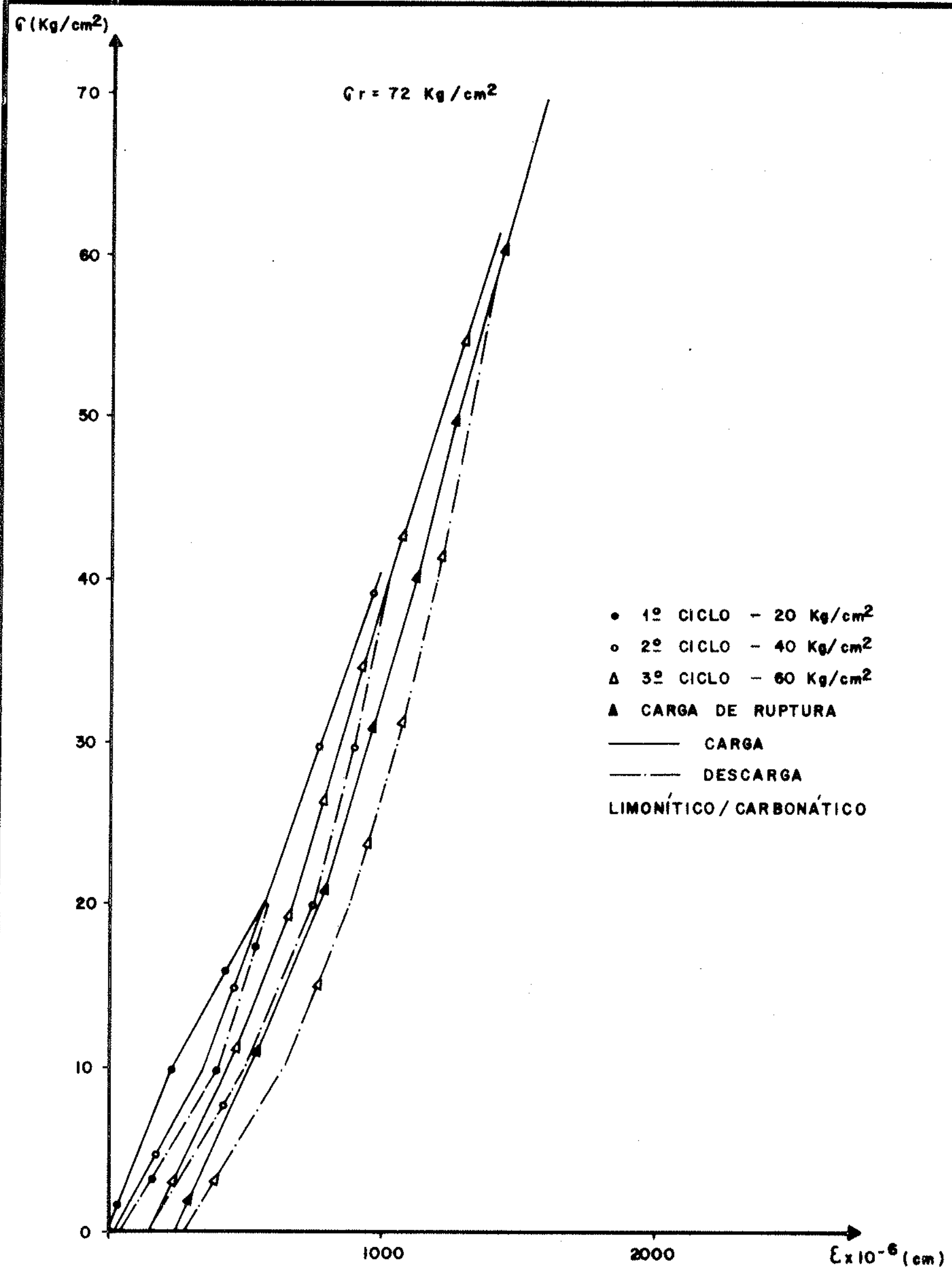

FI6. 44 - ENSAIOS DE DEFORMABILIDADE E COMPRESSÃo SIMPLES COM ARENITO CAIUÁ - AMOSTRA NE 34. 


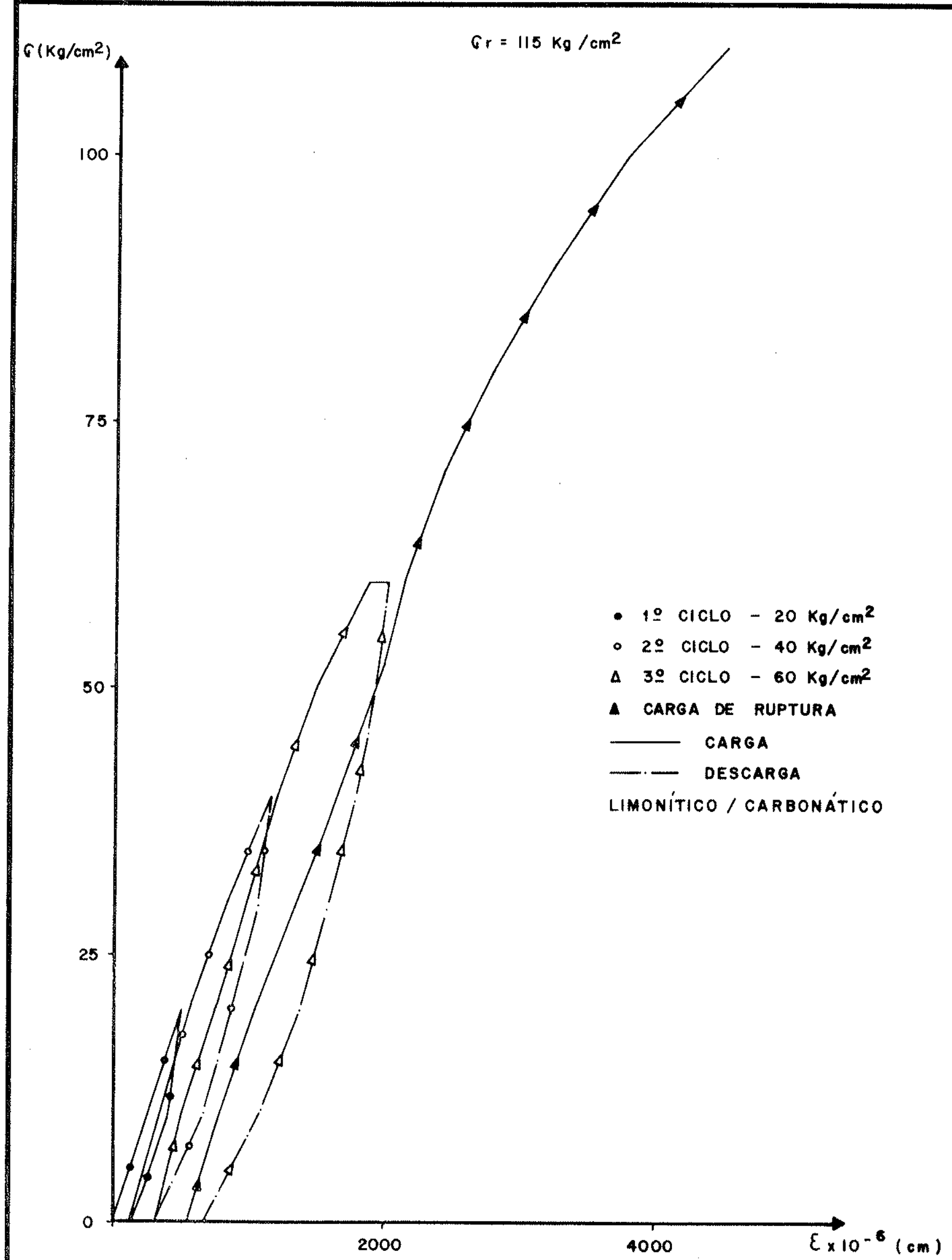

FIG. 45 - ENSADS DE DEFORMABILIDADE E COMPRESSĀO SIMPLES COM ARENITO CAIUÁ - AMOSTRA N: 35 . 


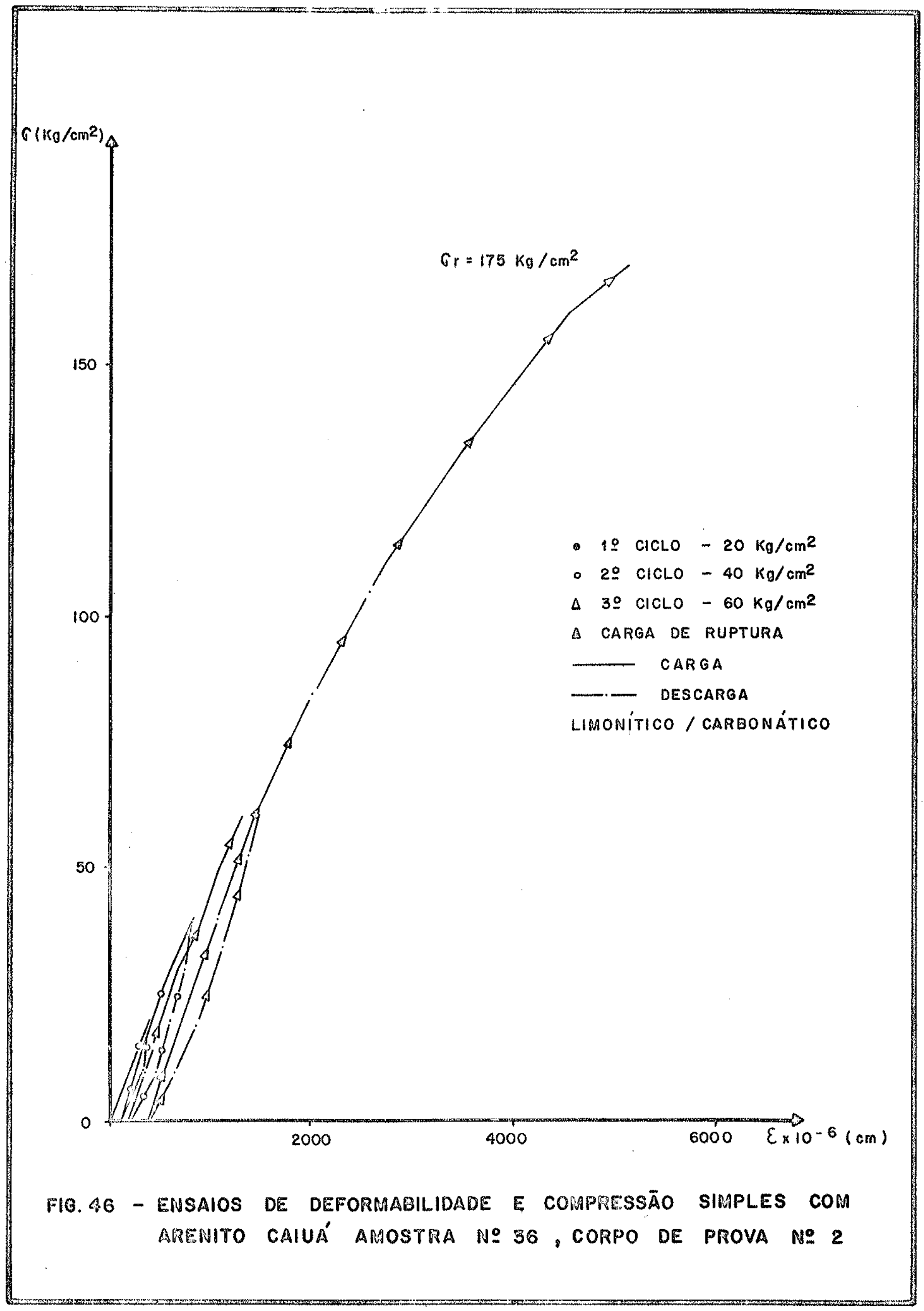




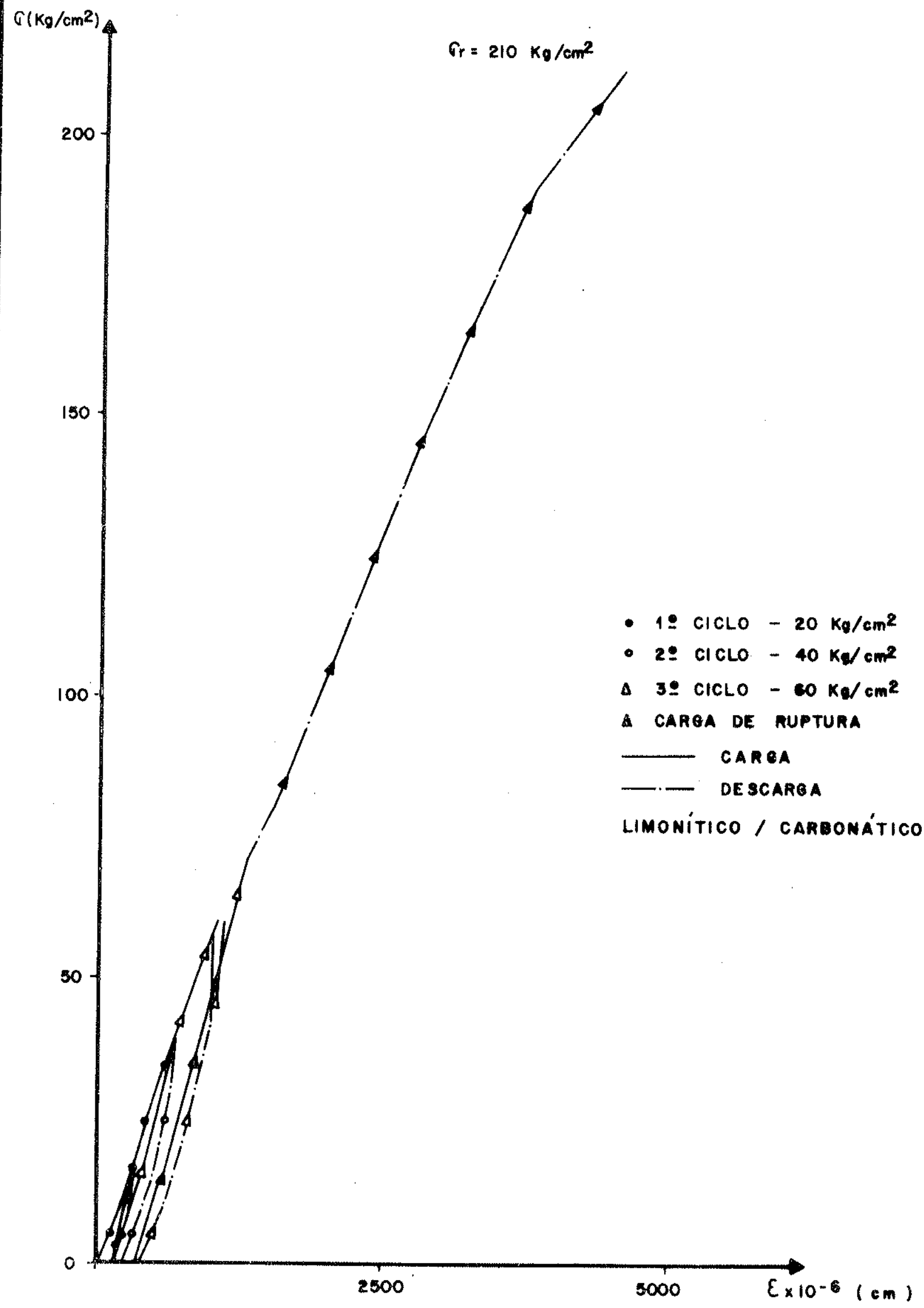

FIG. 47 - ENSAIOS DE dEFORMAGILIDADE E COMPRESSÃo SIMPLES COM ARENITO CAIUÁ - AMOSTRA NE 38. 


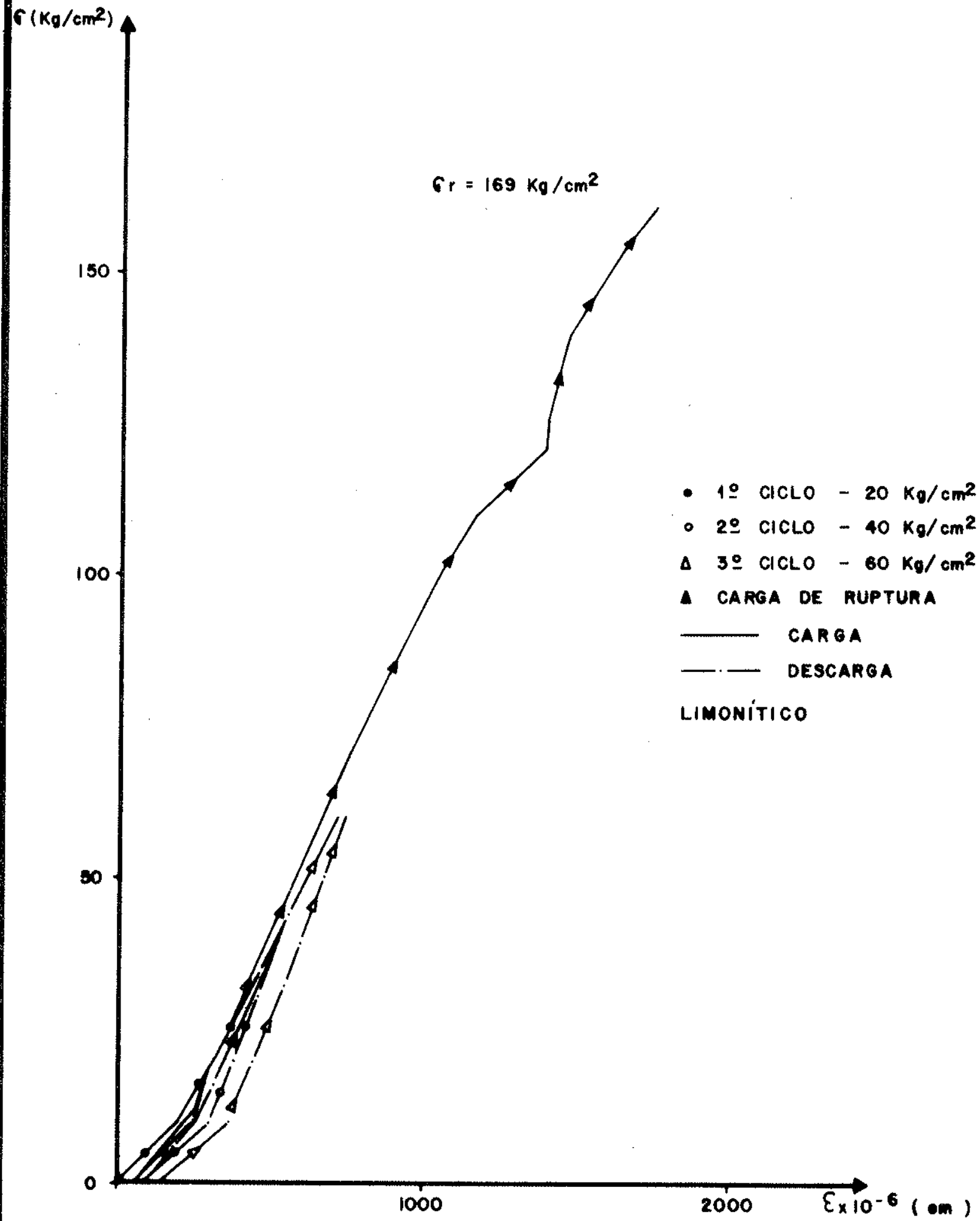

F16. 4 - ENSAIOS dE dEFORMABHLIDAdE E COMPRESSÃo SIMPLES COM ARENITO CAIUÁ - AMOSTRA nE I5, CORPO dE PROVA he 2 


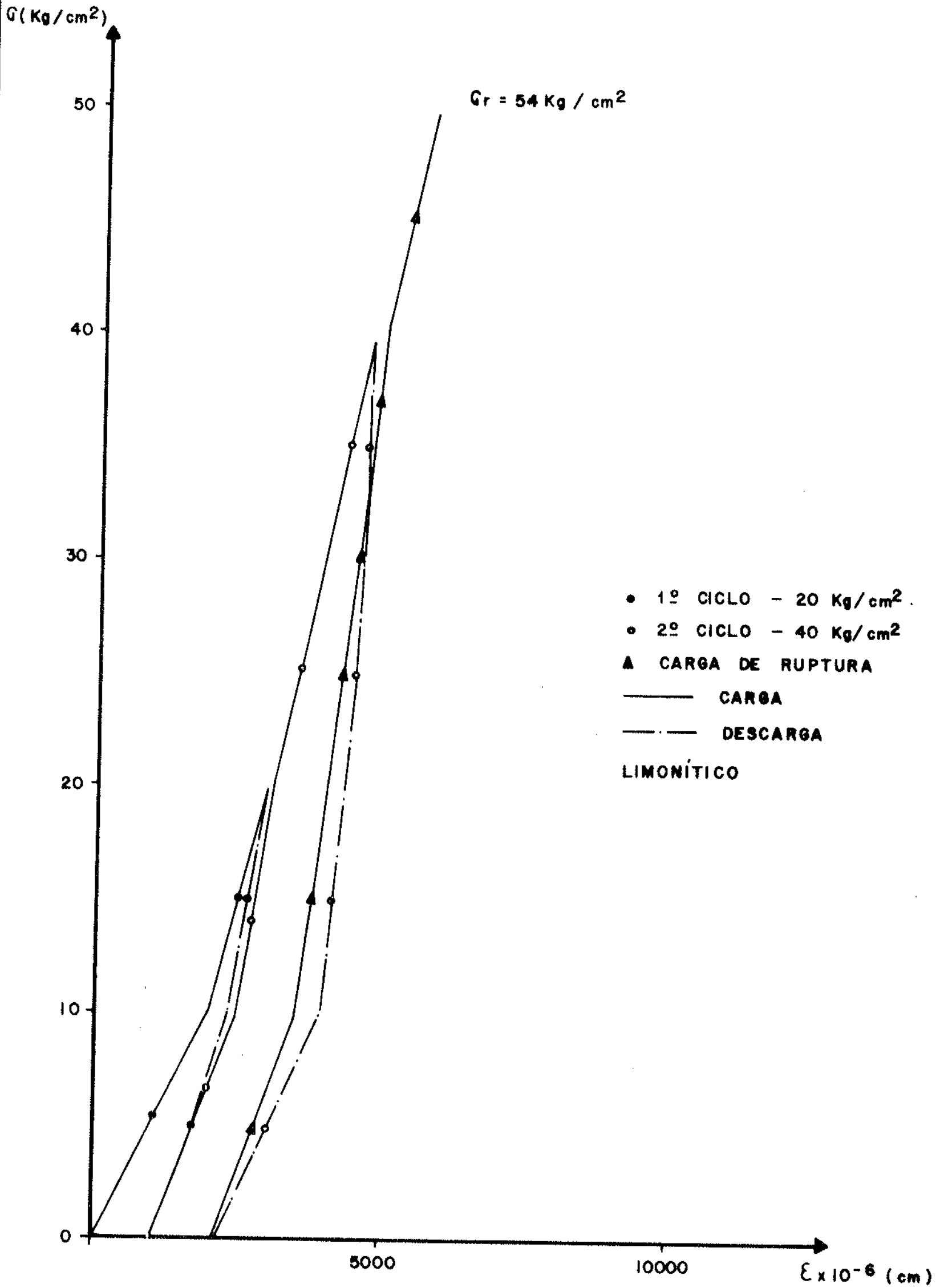

FIG. 49 - ENSAIOS DE deformabilidade E COMPRESSÃo simples COM ARENITO CAIUÁ - AMOSTRA NE 26. 
b) Para as amostras ensaiadas, os maiores valores de Es ou rup correspondem a amostras coletadas nos niveis 204 a 218. As excessōes correspondem às amostras de nümeros $2,2,25$ e 29 , coletadas as altitudes $222,00,226,00$ e $228,00 \mathrm{~m}$, que revelaram valores de $\mathrm{Es}$ por volta de ou bas tante acima de $45.000 \mathrm{~kg} / \mathrm{cm}^{2}$.

c) Os arenitos limoniticos mostram baixos valores de Es, em geral menores que $50.000 \mathrm{~kg} / \mathrm{cm}^{2}$, chegando atê um valor minimo de cerca de $10.000 \mathrm{Kg} / \mathrm{cm}^{2}$ (amostras $19 \mathrm{e} 13$ ).

d) De uma maneira geral, o comportamento quando à deformabilidade ou resistência dos arenitos com cimento carbonätico ë mais satisfatöria do que a dos arenitos com cimento limonitico.

e) Para os ensaios com cimento carbonätico, hä uma tendência a apresentarem propriedades mecânicas melhores em função de sua maior profun didade.

Procurou-se ainda correlacionar o Es e orup com massa específica aparente ( $\gamma a s)$, porosidade aparente ( $F$ a) e absorção d'ägua ( $A b$ ) (Figuras nümeros 50 a 55). Os resultados são os que se seguem:

a) Os maiores valores obtidos de Es referem-se a exemplares de arenitos com cimento carbonático. Porẻm, arenitos limoníticos podem apresentar valores mais altos que os dois primeiros tipos. Quando à resistên cia, a correlação entre orup e ras é bem mais clara no sentido de quanto maior oas maior yrup.

b) Quanto ã absorção $A b$ hã uma manifesta tendência de que quanto menor o seu valor maior o $\mathrm{ES}_{\mathrm{S}}$, sendo que os exemplares que assim se comportam são em geral, os arenitos com cimento carbonático. A mesma lendência se verifica para o orup.

c) No que se refere à porosidade aparente $P_{a}$, ve-se que os areni tos com maiores Es e orup são os menos porosos, e genericamente, tambëm os de cimento carbonätico.

d) Não foi possível correlacionar com precisão a influência da porosidade no comportamento das curvas obtidas nos ensaios de deformabilidade. Observa-se que, para algumas amostras, as curvas têm a concavidade ligeiramente voltada em direção aos a crescentes, o que leva a suspeitar que, nesses casos, nos primeiros momentos da compressão verificou-se uma diminuição da porosidade.

e) Nota-se que, para algumas amostras, a deformação residual re 


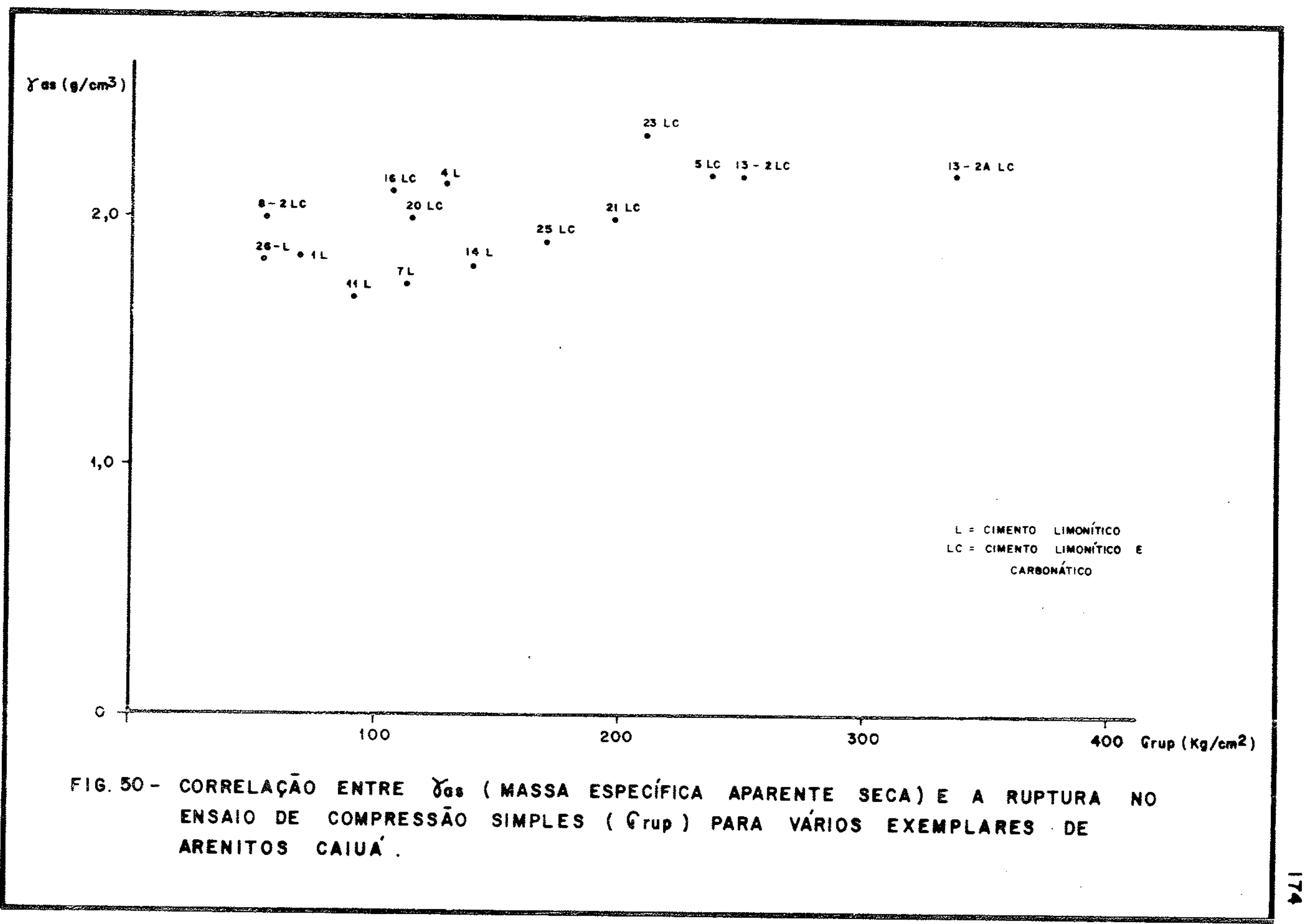




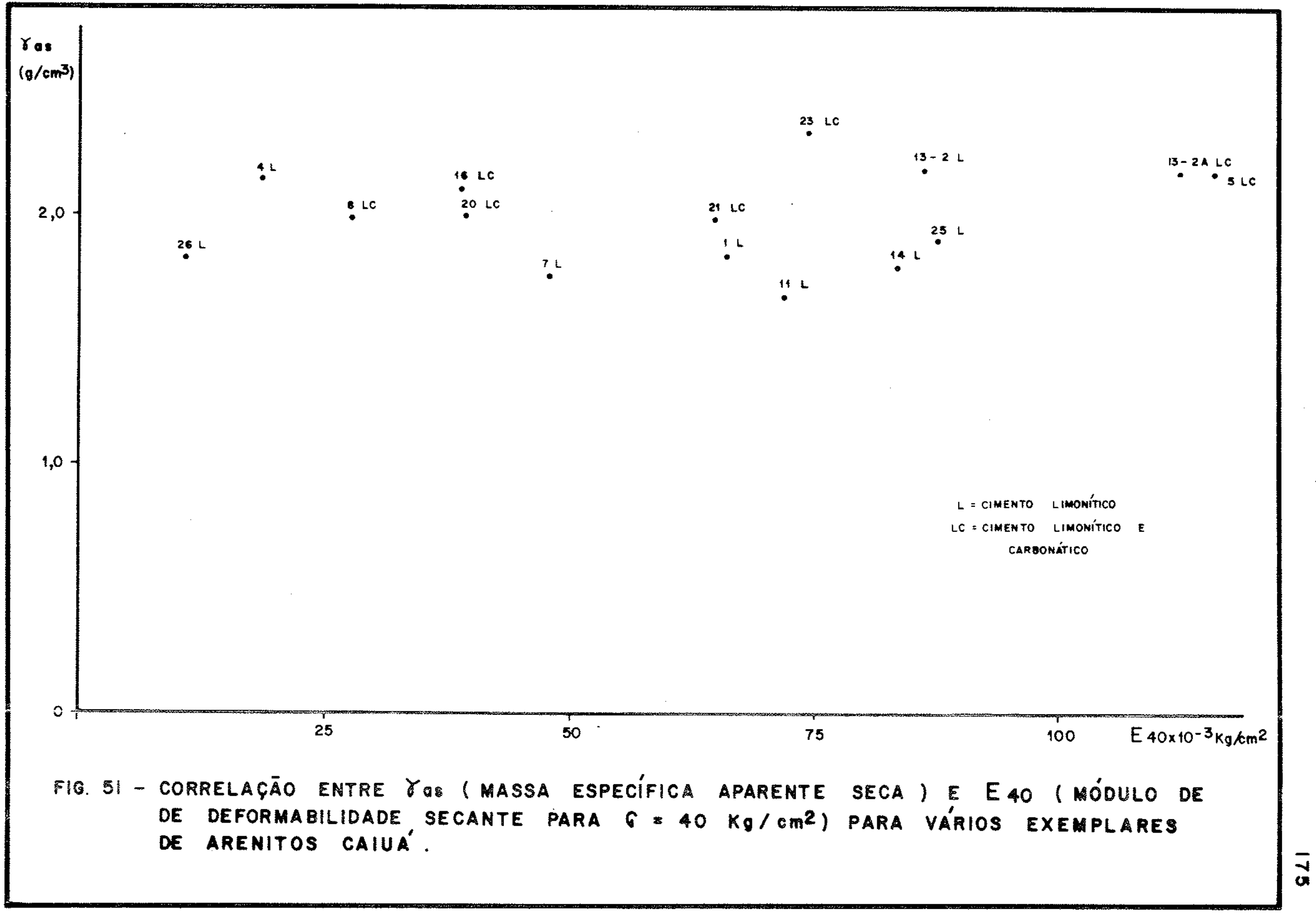




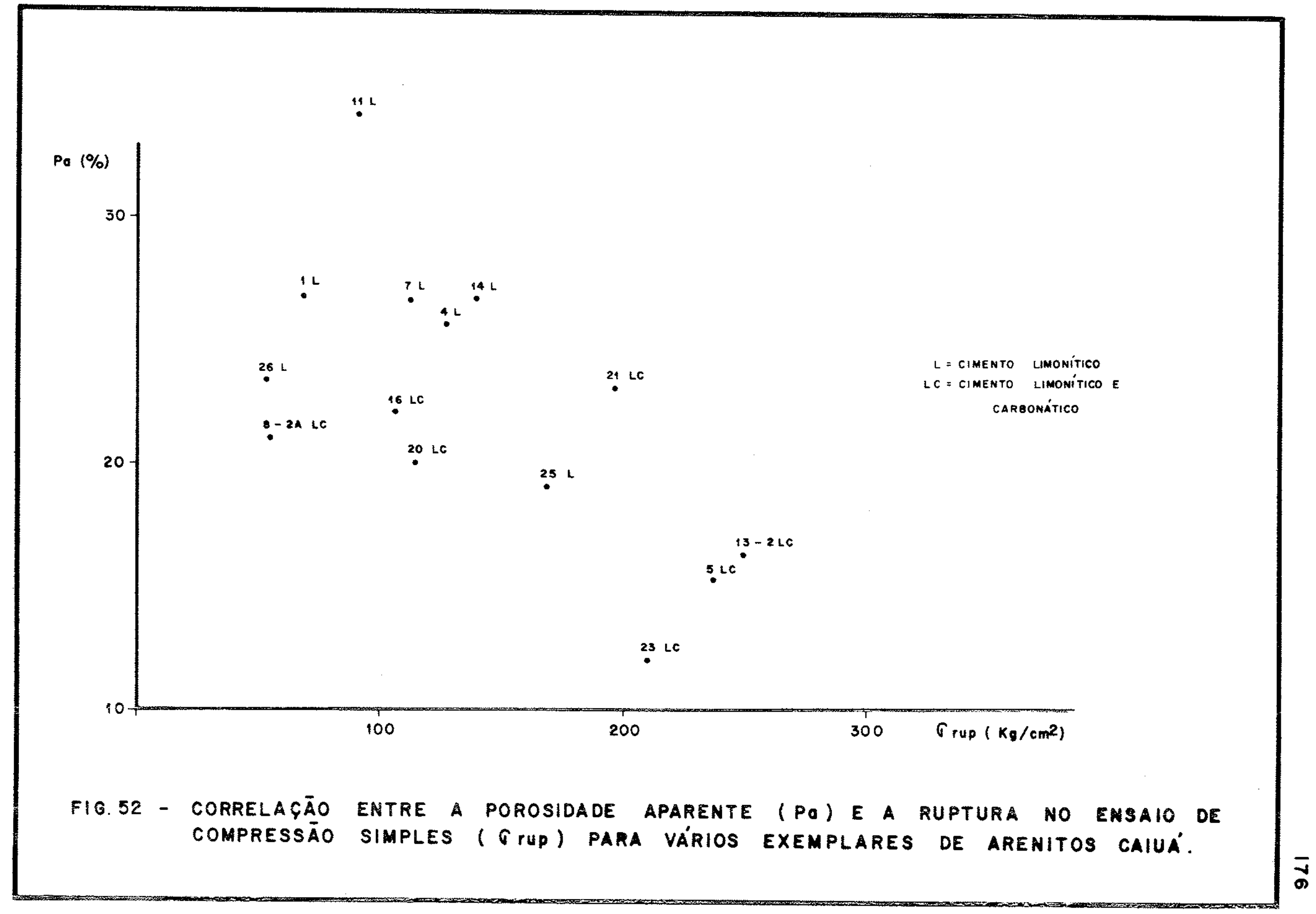




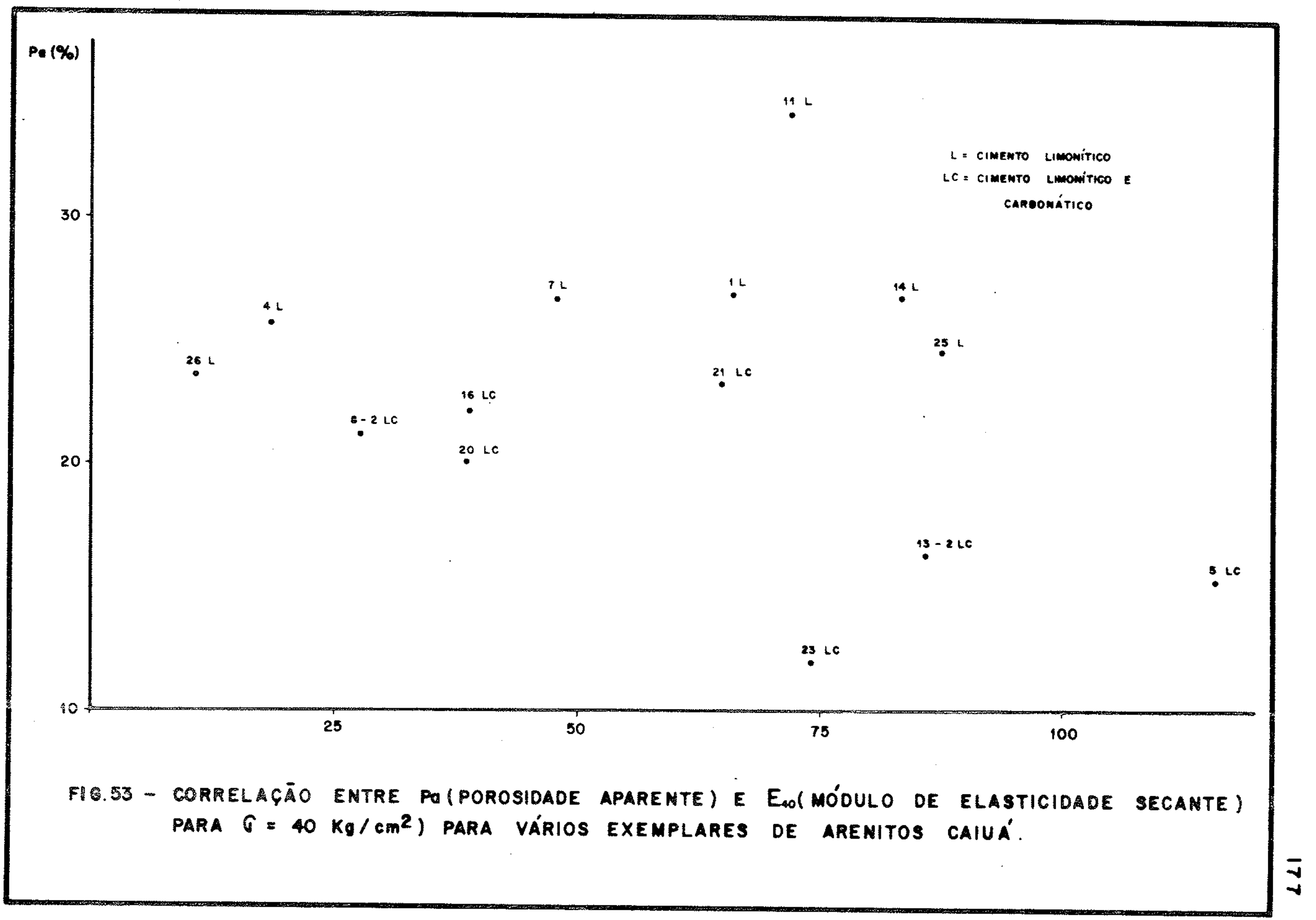




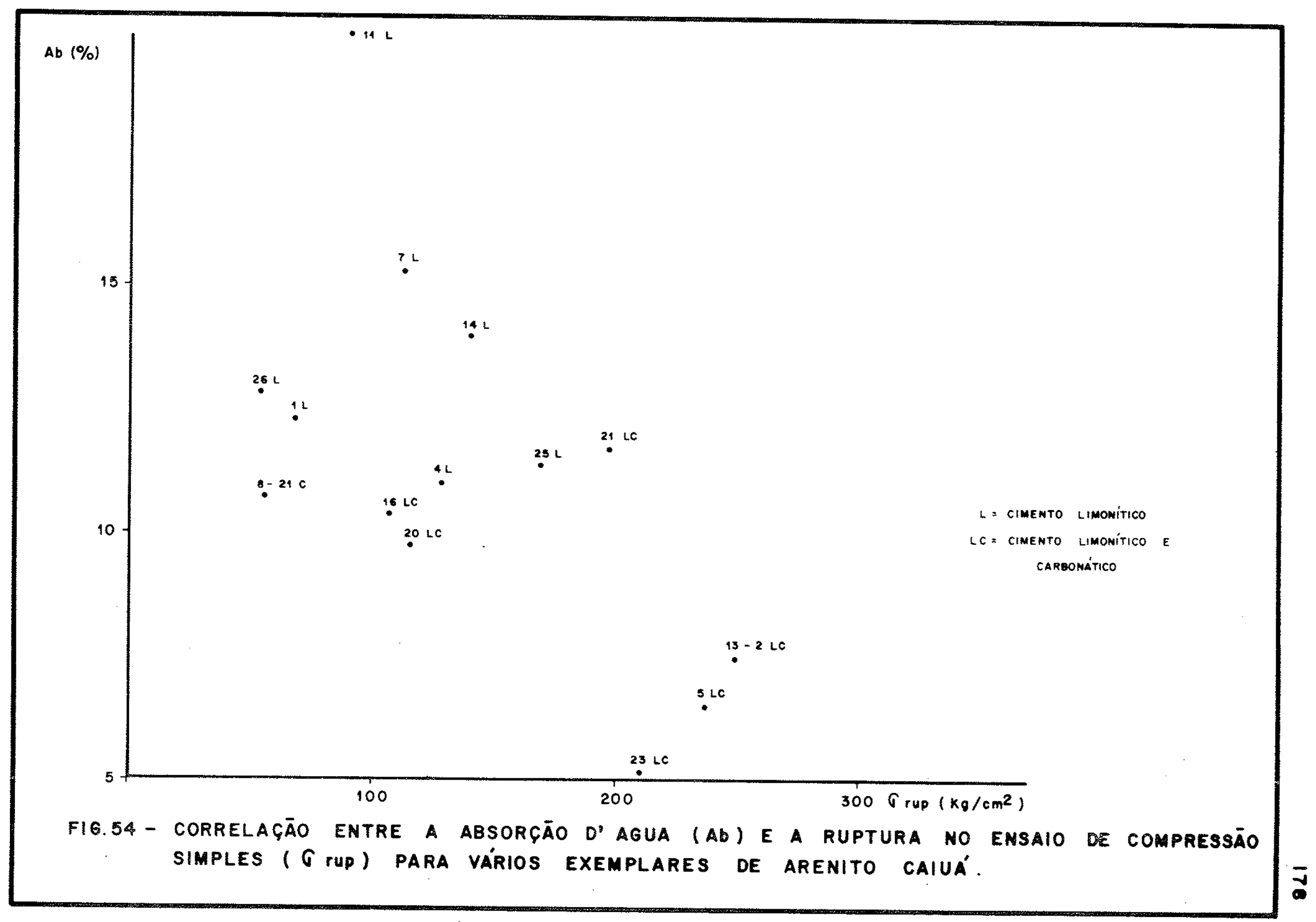




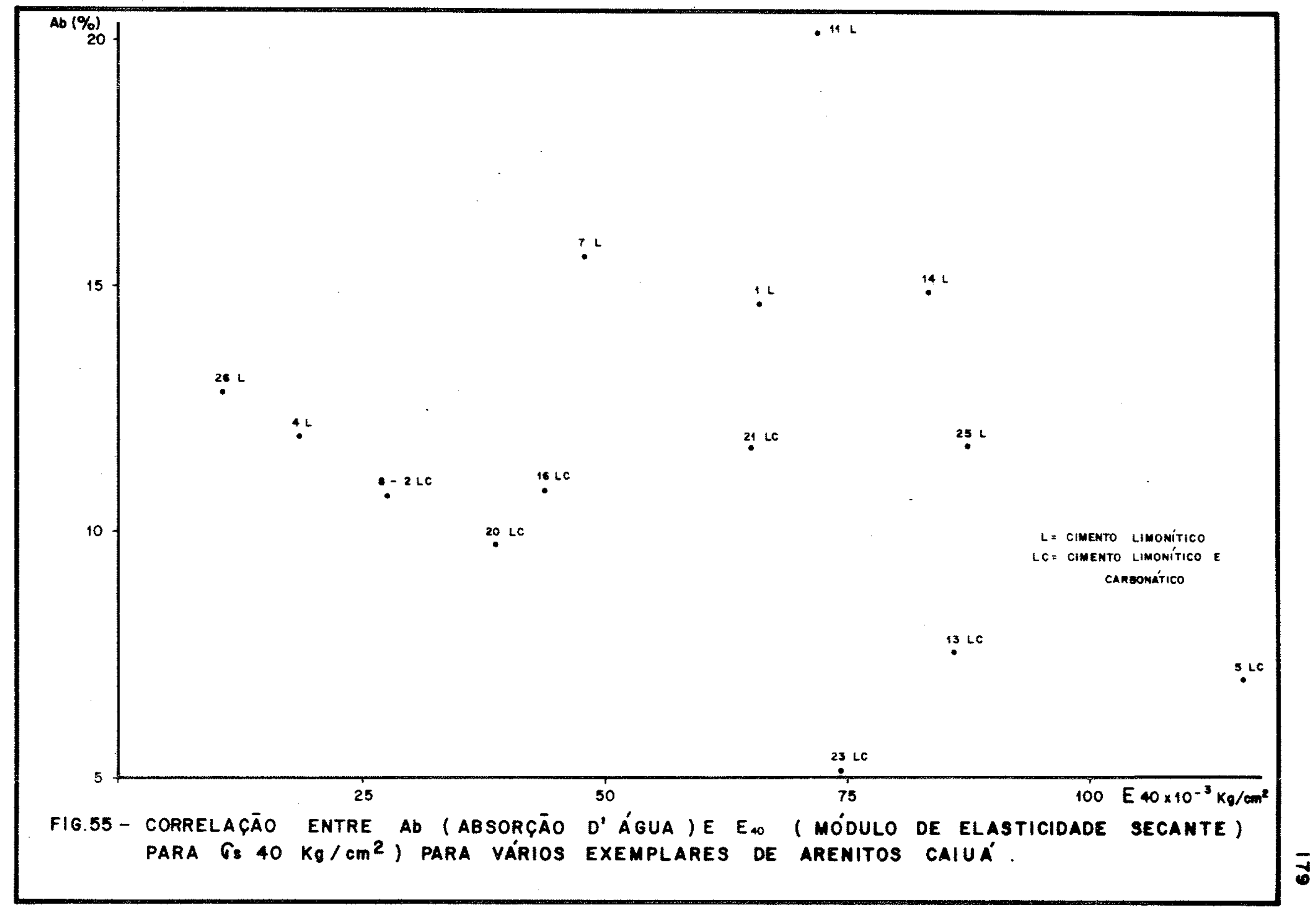


sultante do primeiro ciclo de carregamento $\left(20 \mathrm{~kg} / \mathrm{cm}^{2}\right)$ foi bastante significativa, resultando em baixos valores do mỏdulo de deformabilidade para tal condição, o que significa não haver proporcionalidade entre as tensões e deformações correspondentes. As rupturas aconteceram anteriormente ã fa se plästica, sendo que esta, muito provavelmente, não tenha sido jamais atingida.

Ensalos triaxiais com os arenitos Caiuä

0 material para esses ensaios pertence ao conjunto 1 de amostras, e foi representado pelo Arenito Caiuä limonítico recolhido da escava ção vista nas fotos $2,3,4,5$ e 6 .

As dimensões dos corpos de prova obedeceram ãs normas usuais, ou seja a altura era aproximadamente 2,5 vezes o diâmetro. Procurou-se fazer com que a estratificação ficasse perpendicular ao eixo do corpo de prova.

As amostras foram ensaladas em 4 condições diferentes no que se refere à sua umidade correspondentes a 4 sëries, como se segue:

Sërie A - Na umidade natural;

Sërie B - Após imersão por 24 horas a partir da umidade natural;

Sërie C - Apös um período de 24 horas de secagem em estufa a $100^{\circ} \mathrm{C}$, seguida de um período de 24 horas de saturaçäo por imersão, a partir da umidade natural;

Série D - Apös um período de 24 horas de secagem em estufa a $100^{\circ} \mathrm{C}$, a partir da umidade natural.

A velocidade de carregamento axial foi da ordem de $25 \mathrm{~kg} / \mathrm{min}$.

0 ângulo de atrito interno $(\phi)$ e a coesão (c) do material ensaia do foram obtidos a partir da teorla clässica de resistência das rochas de Coulomb, procurando-se traçar as envoltốrias mais adequadas e calculando-se analiticamente aqueles parâmetros.

Nas tabelas nümeros 56 e 57 . estão relacionados os indices físicos das amostras e os dados possibilitaram o cálculo dos parâmetros c e e o traçado das envoltörias e das curvas $\left(\sigma_{1}-\sigma_{3}\right)$ deformação axial especí fica das figuras nümeros 56 a 59. 
Tabela 56

Ensaios de Compressão Triaxiais - Tndices Físicos Amostras pertencentes ao Conjunto 1

\begin{tabular}{|c|c|c|c|c|c|c|c|c|c|c|}
\hline Sërie & $\begin{array}{l}\text { Amostra } \\
\text { número }\end{array}$ & $\begin{array}{c}\text { Umidade } \\
\text { Natural } \\
\text { h }(\%)\end{array}$ & $\begin{array}{l}\text { Densidade } \\
\text { Natural } \\
\gamma_{\text {nat }} \\
\left(\mathrm{g} / \mathrm{cm}^{3}\right)\end{array}$ & $\begin{array}{c}\text { Absorção } \\
\text { Ab (\%) }\end{array}$ & $\begin{array}{c}\text { Porosidade } \\
\text { Aparente } \\
\text { p. }(\%)\end{array}$ & $\begin{array}{l}\text { Densi dade } \\
\text { Apar } \cdot \text { Seca } \\
\gamma_{s}\left(\mathrm{~g} / \mathrm{cm}^{3}\right)\end{array}$ & $\begin{array}{c}\text { Densidade } \\
\text { dos Grãos } \\
\left(\mathrm{g} / \mathrm{cm}^{3}\right)\end{array}$ & $\begin{array}{l}\text { Porosidade } \\
\text { Real } \\
P_{r}(\%)\end{array}$ & $\begin{array}{c}\text { Indice } \\
\text { dos Vazios } \\
\mathrm{e}\end{array}$ & $\begin{array}{l}\text { Grau de } \\
\text { Saturação } \\
\text { G (\%) }\end{array}$ \\
\hline \multirow{2}{*}{ A } & 47 & 5,62 & 2,11 & 10,80 & 21,12 & 1,96 & 2,67 & 26,72 & 0,34 & 44,13 \\
\hline & 49 & 6,00 & 2,14 & 9,90 & 19,65 & 1,98 & 2,66 & 25,38 & 0,32 & 49,88 \\
\hline \multirow{5}{*}{ B } & 51 & 11,02 & 2,10 & 10,92 & 20,95 & 1,92 & 2,66 & 27,90 & 0,41 & 71,50 \\
\hline & 52 & 10,59 & 2,08 & 10,91 & 21,01 & 1,93 & 2,65 & 27,31 & 00,41 & 68,45 \\
\hline & 53 & 9,80 & 2,12 & 10,48 & 20,56 & 1,96 & 2,65 & 25,92 & 0,37 & 70,19 \\
\hline & 54 & 10,19 & 2,07 & 9,53 & 18,66 & 1,96 & 2,68 & 26,91 & 0,43 & 63,51 \\
\hline & 56 & 10,32 & 2,06 & 10,74 & 20,67 & 1,93 & 2,66 & 27,65 & 00,42 & 65,36 \\
\hline \multirow{6}{*}{$c$} & 57 & 8,37 & 2,19 & - & - & - & 2,68 & - & - & - \\
\hline & 58 & 7,88 & 2,10 & 10,30 & 20,36 & 1,98 & 2,69 & 26,49 . & 0,39 & 54,35 \\
\hline & 59 & 8,49 & 2,16 & 9,81 & 19,39 & 1,98 & 2,69 & 26,51 & 0,35 & 65,25 \\
\hline & 60 & 8,70 & 2,21 & 9,88 & 19,49 & 1,97 & 2,73 & 27,75 & 0,34 & 69,86 \\
\hline & 61 & 8,46 & 2,17 & 10,22 & 19,99 & 1,96 & 2,67 & 26,69 & 0,34 & 66,44 \\
\hline & 62 & 8,67 & 2,24 & 9,71 & 19,19 & 1,98 & 2,70 & 26,80 & 0,31 & 75,51 \\
\hline
\end{tabular}

Obs: + 0 material desagregou durante a saturaçao.

As amostras 45, 4E, 48,50 e 55 não tiveram seus indices físicos determinados por terem sido contaminados pelo óleo da câmara de compressão. 
Tabela 55 - folha 2

\begin{tabular}{|c|c|c|c|c|c|c|c|c|c|c|}
\hline Sërie & $\begin{array}{l}\text { Amostra } \\
\text { nümero }\end{array}$ & $\begin{array}{c}\text { Umidade } \\
\text { Natural } \\
\text { h }(\%)\end{array}$ & $\begin{array}{c}\text { Densidade } \\
\text { Natural } \\
\gamma_{\text {nat }} \\
\left(\mathrm{g} / \mathrm{cm}^{3}\right)\end{array}$ & $\begin{array}{c}\text { Absorção } \\
\text { Ab }(\%)\end{array}$ & $\begin{array}{l}\text { Porosidade } \\
\text { Aparente } \\
\text { P- }(\%) \\
\text { a }\end{array}$ & $\begin{array}{l}\text { Densidade } \\
\text { Apar. Seca } \\
\gamma_{s}(\mathrm{~g} / \mathrm{cm} 3)\end{array}$ & $\begin{array}{c}\text { Densidade } \\
\text { dos Grãos } \\
\left(\mathrm{g} / \mathrm{cm}^{3}\right)\end{array}$ & $\begin{array}{c}\text { Porosidade } \\
\text { Real } \\
P_{r}(\%)\end{array}$ & $\begin{array}{c}\text { Indice } \\
\text { dos Vazios } \\
e\end{array}$ & $\begin{array}{l}\text { Grau de } \\
\text { Saturação } \\
\text { G (\%) }\end{array}$ \\
\hline \multirow{6}{*}{$D$} & 63 & 2,70 & 1,99 & 9,95 & 19,62 & 1,97 & 2,68 & 28,44 & 0,38 & 19,04 \\
\hline & 64 & 2,62 & 1,96 & 9,75 & 19,32 & 1,98 & 2,65 & 25,24 & 0,39 & 17,80 \\
\hline & 65 & 2,72 & 1,99 & 10,12 & 20,01 & 1,98 & 2,67 & 25,92 & 0,38 & 19,11 \\
\hline & 66 & 2,51 & 2,00 & 9,73 & 19,31 & 1,98 & 2,69 & 26,23 & 0,38 & 17,77 \\
\hline & 67 & 2,41 & 1,99 & 10,16 & 20,03 & 1,98 & 2,67 & 26,12 & 0,38 & 16,93 \\
\hline & 68 & 2,36 & 2,00 & 9,88 & 19,55 & 1,98 & 2,67 & 25,86 & 0,37 & 17,03 \\
\hline
\end{tabular}


Tabela 57

Ensaios de Compressão Triaxiais Amostras pertencentes ao Conjunto 1

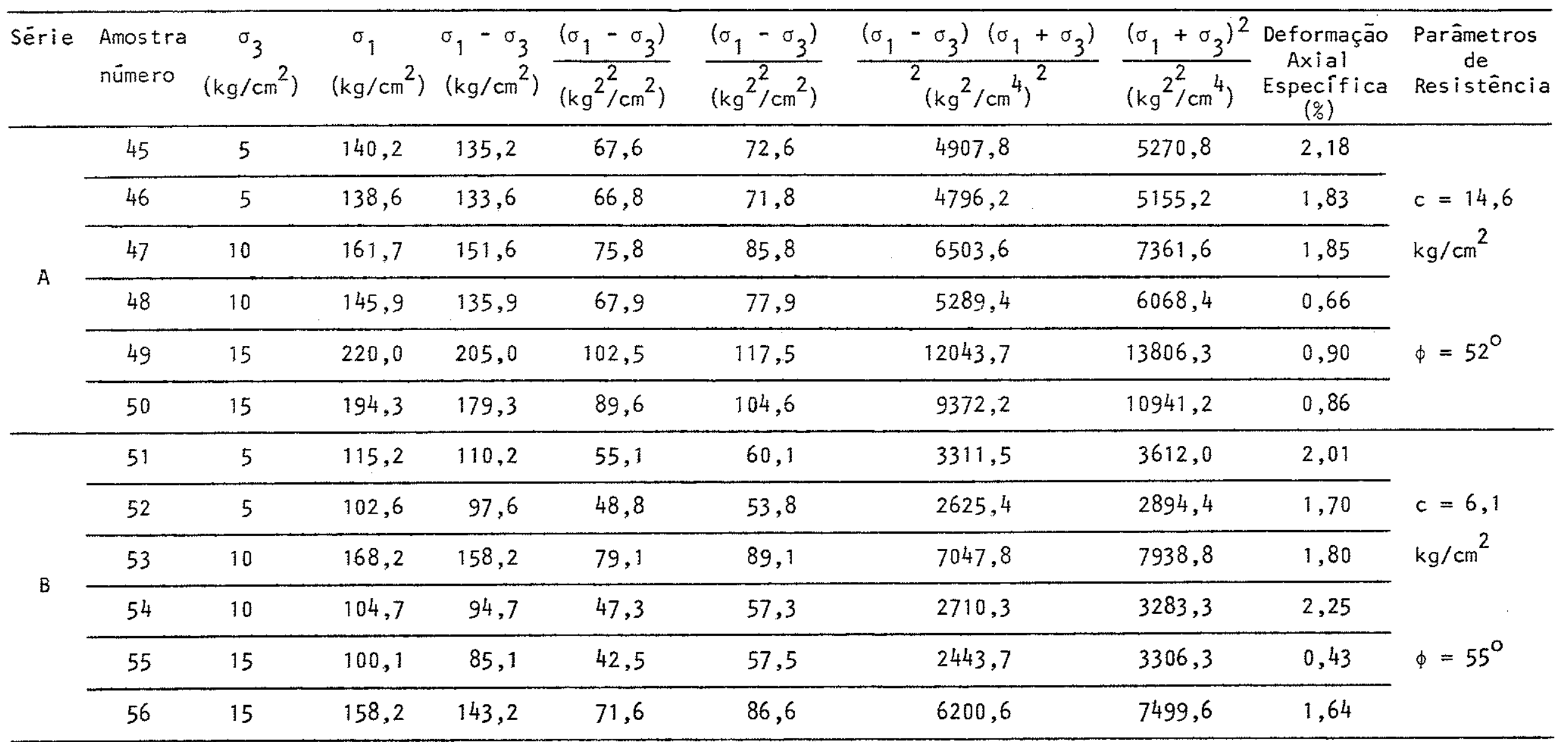


Tabela 57 - folha 2

\begin{tabular}{|c|c|c|c|c|c|c|c|c|c|c|}
\hline Sërie & $\begin{array}{l}\text { Amos tra } \\
\text { nümero }\end{array}$ & $\begin{array}{c}\sigma_{3} \\
(\mathrm{~kg} / \mathrm{cm}\end{array}$ & $\begin{array}{c}\sigma_{1} \\
\left(\mathrm{~kg} / \mathrm{cm}^{2}\right)\end{array}$ & $\begin{array}{l}\sigma_{1}-\sigma_{3} \\
\left(\mathrm{~kg} / \mathrm{cm}^{2}\right)\end{array}$ & $\frac{\left(\sigma_{1}-\sigma_{3}\right)}{\left(\mathrm{kg}^{2} / \mathrm{cm}^{2}\right)}$ & $\frac{\left(\sigma_{1}-\sigma_{3}\right)}{\left(\mathrm{kg}^{2} / \mathrm{cm}^{2}\right)}$ & $\frac{\left(\sigma_{1}-\sigma_{3}\right)}{2\left(\mathrm{~kg}^{2} / \mathrm{cm}^{4}\right)^{2}}$ & $\frac{\left(\sigma_{1}+\sigma_{3}\right)^{2}}{\left(\mathrm{~kg}^{2} / \mathrm{cm}^{4}\right)}$ & $\begin{array}{l}\text { Deformação } \\
\text { Axial } \\
\text { Especifica } \\
(\%) \\
\end{array}$ & $\begin{array}{c}\text { Parâmetros } \\
\text { de } \\
\text { Resistência }\end{array}$ \\
\hline \multirow{6}{*}{$c$} & 57 & 5 & 61,6 & 56,6 & 28,3 & 33,3 & 942,4 & 1108,9 & 0,36 & \multirow{6}{*}{$\begin{array}{l}\mathrm{c}=3,6 \\
\mathrm{~kg} / \mathrm{cm}^{2} \\
\phi=52^{\circ}\end{array}$} \\
\hline & 58 & 5 & 102,6 & 97,6 & 48,8 & 53,8 & 2625,4 & 2894,4 & 1,95 & \\
\hline & 59 & 10 & 155,9 & 145,8 & 73,0 & 83,0 & 6059,0 & 6889,0 & 1,95 & \\
\hline & 60 & 10 & 128,7 & 118,7 & 59,4 & 69,4 & 4122,4 & 4816,4 & 1,91 & \\
\hline & 61 & 15 & 138,4 & 123,4 & 61,7 & 76,7 & 4732,4 & 5882,9 & 0,89 & \\
\hline & 62 & 15 & 80,7 & 65,7 & 32,9 & 47,9 & 1575,9 & 2294,4 & 1,47 & \\
\hline \multirow{6}{*}{$D$} & 63 & 5 & 153,0 & 148,0 & 74,0 & 79,0 & 5846,0 & 6241,0 & 1,96 & \multirow{6}{*}{$\begin{array}{l}\mathrm{c}=11,1 \\
\mathrm{~kg} / \mathrm{cm}^{2} \\
\phi=55^{\circ}\end{array}$} \\
\hline & 64 & 5 & 101,1 & 96,1 & 48,0 & 53,0 & 2544,0 & 2809,0 & 0,65 & \\
\hline & 65 & 10 & 192,9 & 182,9 & 91,5 & 101,5 & 9287,3 & 10302,3 & 2,30 & \\
\hline & 66 & 10 & 179,4 & 169,4 & 84,7 & 94,7 & 8021,1 & 8968,1 & 1,75 & \\
\hline & 67 & 15 & 187,8 & 172,8 & 86,4 & 101,4 & 8761,0 & 10282,0 & 2,32 & \\
\hline & 68 & 15 & 210,4 & 195,4 & 97,7 & 112,7 & 11010,8 & 12701,0 & 1,85 & \\
\hline
\end{tabular}



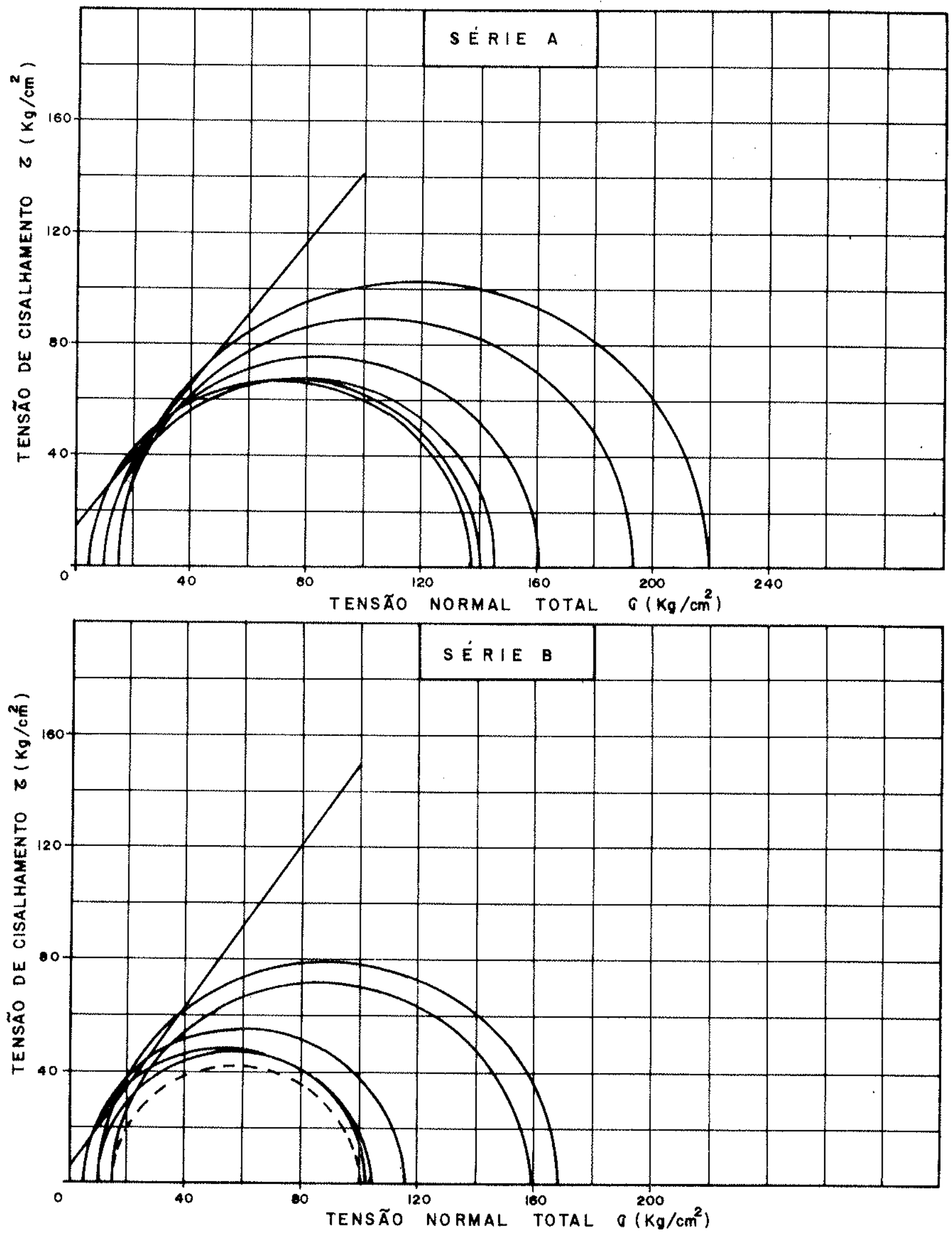

FIG. 56 - ENSAIOS TRIAXIAIS COM O ARENITO CAIUÁ - ENVOLTÓRIAS DE MOHR. 

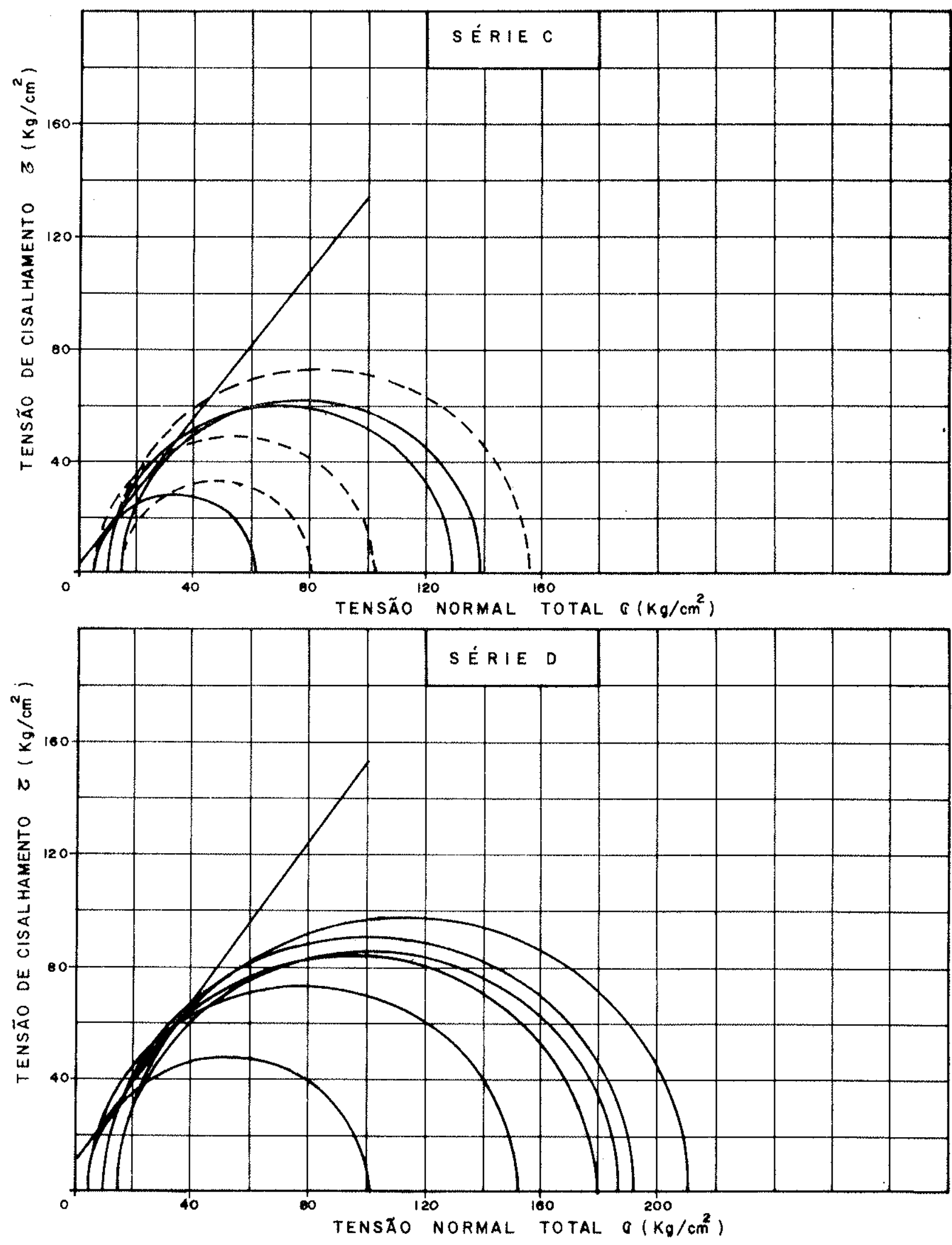

FIG. 57-ENSAIOS TRIAXIAIS COM O ARENITO CAIUA-ENVOLTÓRIAS DE MOHR. 


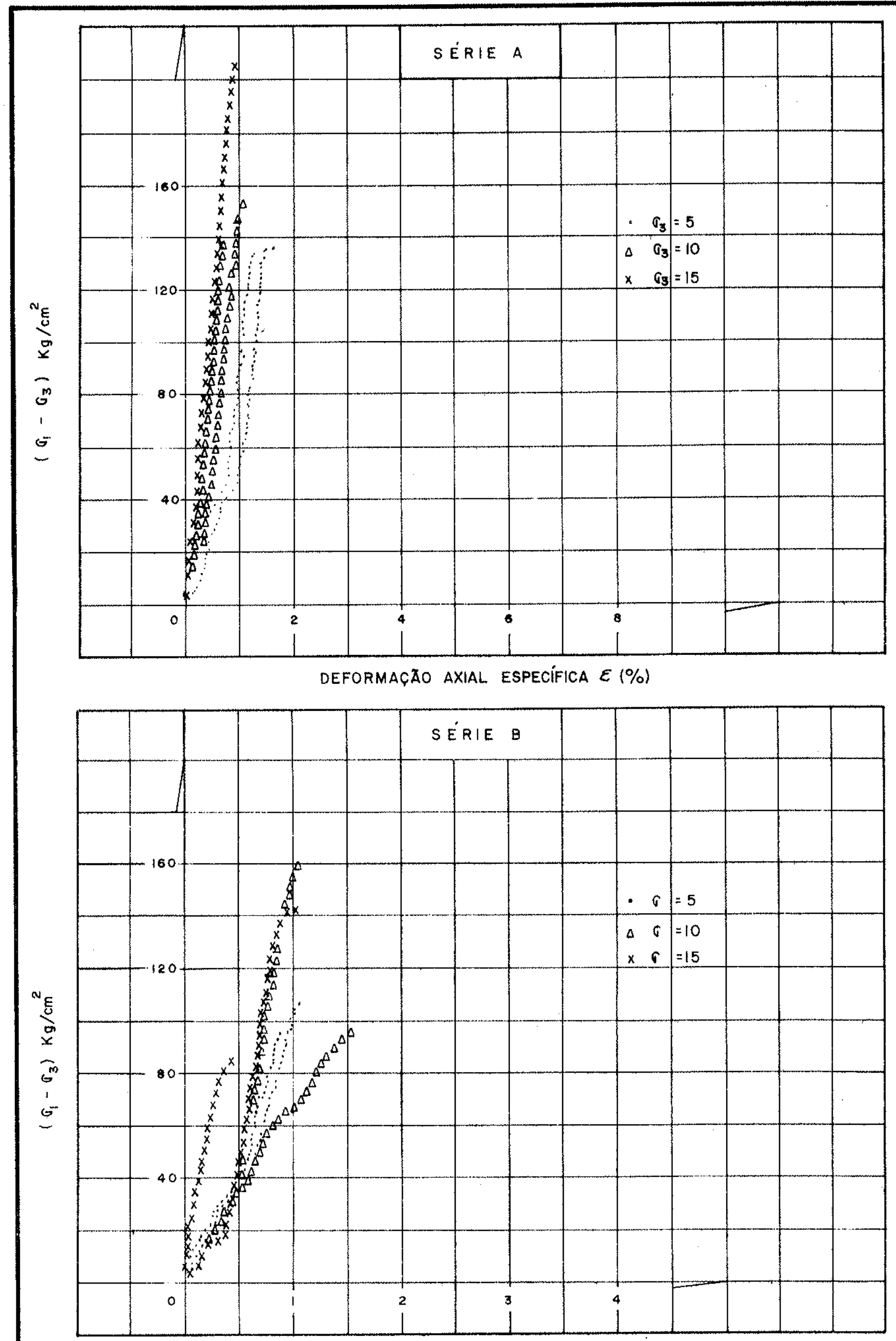

DEFORMAÇÃO AXIAL ESPECIFICA $\varepsilon(\%)$

FIG. 58 - ENSAIOS TRIAXIAIS COM O ARENITO CAIUA'-CURVAS $\left(\sigma_{1}-\sigma_{3}\right)$ 


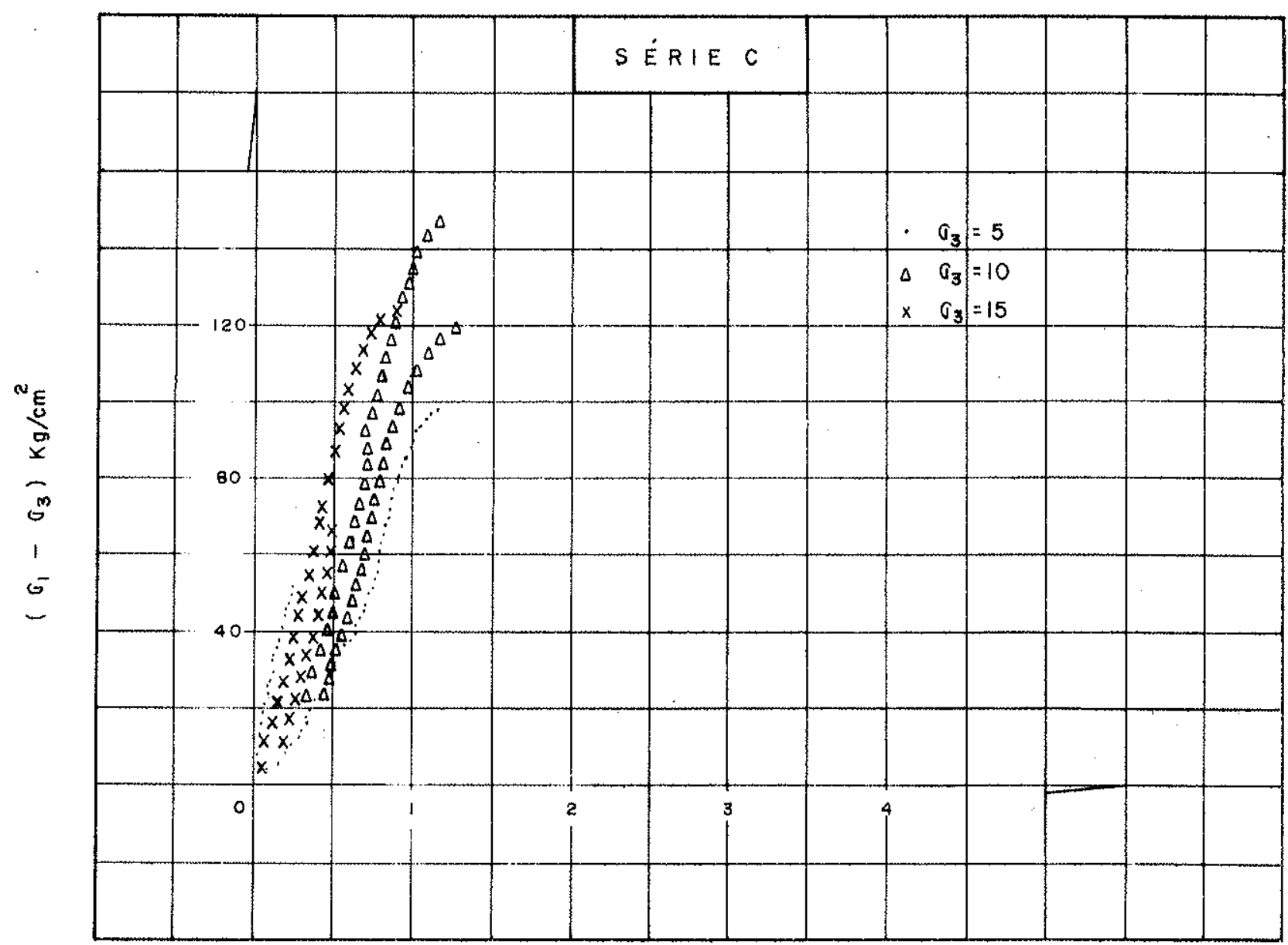

DEFORMAÇÃO AXIAL ESPECIFICA $\varepsilon(\%)$

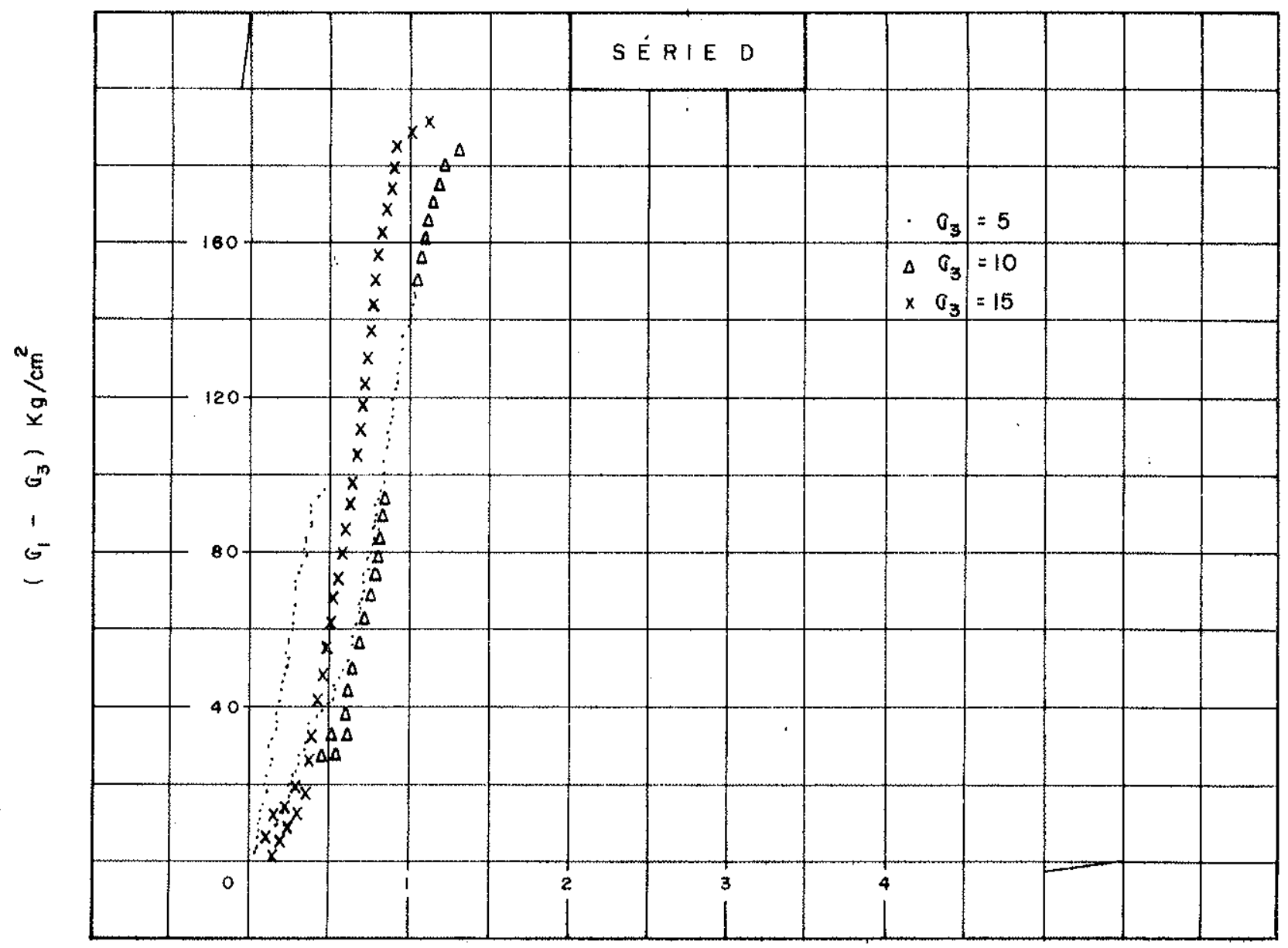

DEFORMAÇ̃̃O AXIAL. ESPECIFICA $E(\%)$

FIG. 59- ENSAIOS TRIAXIAIS COM O ARENITO CAIUÁ-CURVAS $\left(\sigma_{1}-G_{3}\right)$ 
Pode-se verificar que, para cada sêrie de amostras ensaiadas a uma determinada umidade, foram conslderados 6 corpos de prova a tensões $\sigma_{3}$ de 5,10 e $15 \mathrm{~kg} / \mathrm{cm}^{2}$.

\section{Consideraçōes sobre os ensaios triaxiais}

Segundo Rocha (1971), a simulação das condições de solicitações triaxiais em rochas são geralmente realizados aplicando-se ao corpo de pro va uma pressão lateral por meio de um líquido, e uma compressão axial. As pressões laterais (de confinamento) podem atingir os $500 \mathrm{~kg} / \mathrm{cm}^{2}$, o que exi ge uma câmara triaxial constituida por cilindro de aço de parede espessa. As deformaçōes transversais e longitudinais do corpo de prova podem ser medidas por meio de extensômetros, em geral elëtricos. Alguns equipamentos permitem manter as pressões laterais e axiais constantes por longos períodos, o que possibilita o estudo do comportamento do corpo de prova sob fluência.

Os ensaios triaxiais põem em evidência a grande influência de pressão lateral sobre a deformabilidade e resistência das rochas. Verifica -se que, com o aumento da pressão hidrostảtica, aumentam os valores do mödulo de deformabilidade e a resistência. No entanto, quando se trata de ro chas bastante compactas, com valores da resistência ã compressão da ordem de $1000 \mathrm{~kg} / \mathrm{cm}^{2}$ ou mais, o mỏdulo de deformabilidade jä não sofre mais aque la influência.

E de grande interesse analisar-se as deformações que precedem 0 momento da ruptura, nos ensaios triaxiais. Sabe-se que, nos ensaios de cisalhamento direto, apös ter sido atingida uma tensão de cisalhamento máxi ma max, a tensão tangencial diminui tendendo para um valor que se costuma designar por resistência residual ${ }^{\sigma} r$, sendo que aquela representa $o$ instante em que se inicia a desorganização da estrutura do material ensaia do. A medida em que o ensalo prossegue, o material cisalhado no plano de ruptura move-se entre os dois blocos que se separam, tendendo à formação de uma camada granular da qual dependerä, em grande parte, o valor da resistência residual.

Ensaios triaxiais realizados com märmores de Carrara, mostraram que a partir de pressões confinantes de $500 \mathrm{~kg} / \mathrm{cm}^{2}$, as curvas deixam de apresentar o valor $G \max$, sendo que, apỏs atingido o ponto de cedência, as deformações crescem a uma tensão constante e para valores de $\sigma_{3}$ superiores 
ao ponto de cedência, as deformações crescem com as tensões atingindo valores muito elevados. On seja, a partir do aumento das pressões hidrostäti cas, as rochas podem sofrer grandes deformações, o que, juntamente com 0 aumento da temperatura em profundidade e sob solicitações que durem muito tempo, explica ofato de a crosta terrestre poder sofrer, muitas vezes, grandes deformações sem a ocorrência de fraturas. Portanto, as designações düctil, frägil e plâstlico, que se costuma aplicar aos materiais pëtreos, multas vezes o são inadequadamente, pois tais termos estão necessariamente vinculados a estados de tensões evolutivos atẽ a ocorrência da ruptura, 0 comportamento dito frägil ocorre quando, atë a ruptura somente ocorrem pequenas deformações permanentes, ou se elas forem grandes, dar-se-ão com grandes perdas de resistência (curvas I e II, Figura 60 ). Por outro lado um material chamado düctil, pode suportar deformações permanentes importantes sem perda de resistência apôs o ponto de cedência, ou seja, se submetido a ciclos de carga e descarga, a curva original tensões-deformações ê seguida como se o ciclo não tivesse acontecido. Neste caso, as curvas tensões-deformações podem apresentar-se, após a zona de cedên cia, paralelas ao eixo das deformações, e então o material é dito ter comportamento plästico, ou ligeiramente encurvadas no sentido dos $\left(\sigma_{1}-\sigma_{3}\right)$ crescentes (curvas 111 e IV, Figura 60).

Uma das grandes dificuldades com a qual se defronta no que se refere ã ruptura sob solicitação triaxial ẽ o conhecimento das condições em que pode ocorrer a destruição de um elemento de volume de material para que se possa prever a consequente destruição da obra, jã que o estado de tensões varia de ponto para ponto, sendo necessärio então, estabelecer hipōteses simplificadoras para o fenômeno.

Quando se estuda a ruptura de materiais isótropos, a ruptura esta rà associada à consideração de três parâmetros ou os três valores das tensões normais atuando nas faces de um paralelepípedo do material ensaiado. Para os materiais anisötropos, deve-se considerar a orientação e a caracte ristica da anisotropia em relação a essas tensões (Rocha, 1971).

Com relação especificamente aos ensaios realizados, o seu tratamento e interpretação permitiram uma avaliação relativa à resistência dos arenitos Caiuã ensaiados, como segue:

a) 0 ângulo de atrito interno $(\phi)$ do material mostrou ser pouco influenciävel nas 4 diferentes condiçoes de ensaio já descritas, variando de apenas $3^{\circ}\left(52^{\circ}=\phi_{\min } ; 55^{\circ}=\phi_{\max }\right)$; 


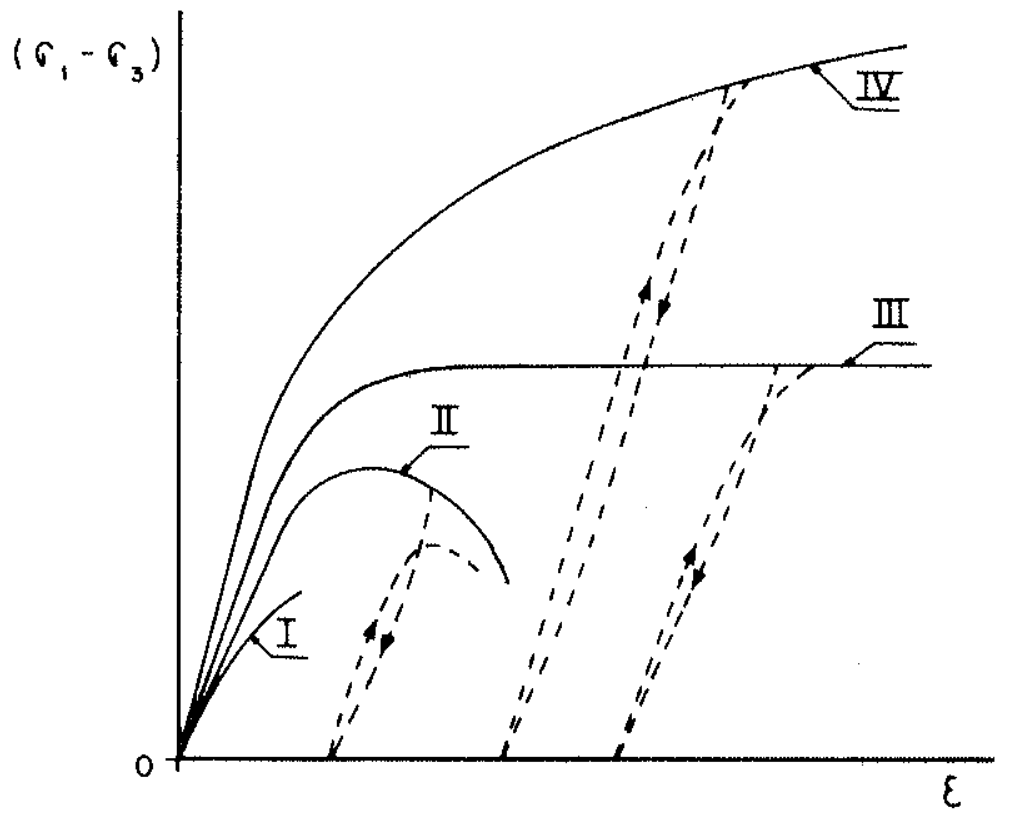

FIG. 60 - COMPORTAMENTOS FRÁGIL, DÚCTIL E PLÁstico de ROCHAS, SEGUNDO VALORES CRESCENTES DA DIFERENCA $\left(a_{1}-\sigma_{3}\right)$. 
b) Por outro lado, a coesão (c) mostrou seu maior valor nas cond ções de umidade natural. Vemos que seu menor valor corresponde ãs condi ções de sërie c. A explicação para esse fato talvez possa ser aventada como tendo havido um enfraquecimento do cimento limonítico pela saturação por 24 horas precedida pela secagem em estufa a $100^{\circ} \mathrm{C}$;

c) O fato do ângulo de atrito ser menos sensivel ãs condições de saturação e secagem referidas, pode ser entendido como se os planos de es tratificação possam ter uma integridade maior que aquela representada pe las forças responsâveis pela coesão, ou em outras palavras, que num proces so de deteoriração gradativa do sedimento, a estratificação seja destruída por ültimo, apös o cimento, tal a debilidade deste, nos Arenitos Caiuá;

d) Examinando-se as figuras nümeros 58 e 59 , conclui-se que o com portamento dos arenitos Caluä ensaiados ê caracteristicamente frägil , den tro dos estados de tensões vigentes durante os ensaios. Não ficou plenamen te demonstrada a influência das tensões de confinamento no processo, tal vez pelo fato de que as mesmas não tenham atingido valores iguais ou acima do ponto de cedencia. No entanto, particularmente nas amostras de serie A, nota-se uma tênue tendência de o material suportar maiores deformações antes da ruptura, com maiores valores de $\sigma_{3}$.

\section{Ensaios de permeabilidade com o Arenito Caiuä}

As amostras para estes ensaios provieram do local 11 .

Foram ensalados 10 exemplares, sendo 5 de arenitos resistentes e 5 de arenitos friäveis, todos limoniticos.

$\mathrm{Na}$ tabela nümero 58 verificam-se os dados utilizados na caracteri zação da permeabilidade e os resultados de $k$ obtidos.

Como se verifica, são baixos os valores da permeabilidade.

Faz-se necessärio refletir sobre esta aparente contradição, ou se ja porque arenitos com porosidade real geralmente acima de $30 \%$ e porosidade aparente da ordem de $20 \%$, apresentam tais valores de permeabilidade.

Para isto, é necessärio definir-se o que seja "porosidade efet vall como sendo

$$
P_{e}=\frac{\text { Volume de vazios intercomunicantes }}{\text { volume total }} \times 100
$$


Quer dizer que o parâmetro acima configura algo fundamental na permissividade ã passagem do líquido na massa da rocha, jã que pressupõe uma comunicação dos vazios.

Por outro lado, entre as propriedades que afetam a permeabilidade estão a granulometria, arranjo, prientação estrutura dos grãos, cimenta ção e acamamento, todos associados de uma maneira bastante complexa e ainda não completamente compreendida. Sabe-se que quanto mais compacto o "empacotamento" da areia, menor $\hat{e}$ a sua porosidade efetiva e portanto menor a sua permeabilidade, permanecendo constante os outros fatores.

A orientação e o arranjo da estrutura dos grãos, aparentemente têm um controle muito fraco sobre a permeabilidade no plano de acamamento $e$ maior controle nas seções verticais paralelas à direção do transporte(Mast e Porter, 1963). Na deposição, os grãos acumulam-se com seus eixos parale los ã corrente e se imbricam na direção conträria á mesma com ângulos de $15^{\circ}$ a $18^{\circ} \mathrm{com}$ a superfîcie deposicional, o que origina uma anisotropia no sistema de poros do material.

0 acamamento tambëm tem um efeito importante, talvez mais do que a estrutura, na permeabilidade, jä que durante pequenas pausas no processo deposicional ocorrem acumulações de lâminas argilosas delgadas de baixa permeabilidade que inibem consequente ofluxo vertical. Então o "fabric" e as laminações fazem com que a permeabilidade vertical seja menor que a horizontal, enquanto que a orientação dos grãos confere uma fraca anisotro pia à permeabilidade no plano do acamamento. A permeabilidade é portanto, uma propriedade direcional.

Distribuições estatísticas da permeabilidade e da porosidade em reservatörios, particularmente em acamamentos de mesma "fäcies", tendem a uma distribuição lognormal para a primeira e tipicamente normal para a segunda.

Alêm disso, a variância da permeabilidade è muito maior do que a da porosidade, e pode variar marcadamente centimetro a centímetro, na vertical.

Provavelmente, duas razões que explicam o porque da permeabilidade ser muito mais variävel que a porosidade nos arenitos, são o fato de que uma dada porosidade não representa uma "tela" formada pelas rugosida des das paredes do sistema de poros, no caminho do fluido, nem o padrão do caminho que o mesmo terä que percorrer entre dois pontos da rocha. Uma mudança qualquer naqueles padrões pode alterar a permeabilidade sem provo- 
car o mesmo com a porosidade (Pettijohn, Potter e Siever, 1972).

No caso dos Arenitos Caiuá, depara-se com uma realidade de dificil compreensão, pois pode-se imaginar que a porosidade efetiva seja alta se a correlacionarmos com os valores da absorção d'ãgua (da ordem de 10 a 15\%). Pensa-se que, mul to embora a fração argila existente nesses sedimen tos seja inexpressiva (vide curvas granulomëtricas), mesmo assim ela difi culta sobremaneira ofluxo. Pode-se admitir ainda que o gradiente da ordem de 13, não tenha sido suficiente para lixiviar o cimento argiloso, ou que - ambiente do ensaio, do ponto de vista químico, não tenha sido suficiente mente agressivo para a dissolução da parte solüvel do mesmo.

Tabela 57

Ensaios de permeabilidade com os Arenitos Caiuä

\begin{tabular}{|c|c|c|c|c|c|}
\hline $\begin{array}{c}C P \\
\text { nümero }\end{array}$ & $\begin{array}{c}\phi \\
(\mathrm{cm})\end{array}$ & $\begin{array}{c}\mathrm{L} \\
(\mathrm{cm})\end{array}$ & $\begin{array}{l}\text { Area } \\
\left(\mathrm{cm}^{2}\right)\end{array}$ & $\begin{array}{c}\text { Coeficiente de } \\
\text { Permeabilidade } \\
\text { K } 20^{\circ} \mathrm{C} \\
(\mathrm{cm} / \mathrm{seg})\end{array}$ & $\begin{array}{c}\text { Tipo } \\
\text { ensalado }\end{array}$ \\
\hline 69 & 8,95 & 6,97 & 37,94 & $3,44 \times 10^{-6}$ & \multirow{5}{*}{$\begin{array}{l}\text { Arenito } \\
\text { Resistente }\end{array}$} \\
\hline 70 & 6,96 & 9,99 & 38,05 & $2,71 \times 10^{-7}$ & \\
\hline 71 & 6,95 & 10,00 & 37,94 & $7,36 \times 10^{-8}$ & \\
\hline 72 & 6,83 & 9,96 & 36,64 & $1,96 \times 10^{-7}$ & \\
\hline 73 & 6,90 & 9,90 & 37,39 & $1,66 \times 10^{-7}$ & \\
\hline 74 & 6,92 & 11,98 & 37,60 & $1,88 \times 10^{-8}$ & \multirow{5}{*}{$\begin{array}{l}\text { Arenito } \\
\text { Friävel }\end{array}$} \\
\hline 75 & 6,94 & $11,90$. & 37,80 & $6,98 \times 10^{-8}$ & \\
\hline 76 & 6,98 & 11,90 & 38,30 & $3,36 \times 10^{-8}$ & \\
\hline 77 & 6,95 & 11,96 & 37,90 & $1,74 \times 10^{-8}$ & \\
\hline 78 & 6,93 & 11,96 & 37,70 & $6,99 \times 10^{-8}$ & \\
\hline
\end{tabular}


CAPTTULO V

REFLEXÕES QUANTO A APLICAÇÃO DOS ARENITOS CAIUÁ

Notas relativas à rotulação geotécnica dos Are-

nitos em questão

Procurar-se-á, inicialmente, situar os arenitos Caiuā, consideran do-se seus parâmetros físicos e mecânicos, jä apresentados e analisados, no local que thes è reservado, dentro do intervalo de variações dos referidos parâmetros.

Na figura nümero 61, vemos que a variação da resistência à compressão simples dos arenitos ê de 50 atê pouco mais de $2000 \mathrm{~kg} / \mathrm{cm}^{2}$, faixa esta que configura os materiais chamados de "moderadamente fracos" até "muito resistentes" (Wilson, Brocht e Franklim). Os Arenitos Caiuä ensaiados sob compressão simples, apresentaram resultados variäveis entre 54 e $237 \mathrm{~kg} / \mathrm{cm}^{2}$, o que autoriza inclui-los na faixa dos materiais "moderadamente fracos" atê "moderadamente resistentes", de acordo com a referida clas" sificação.

Rocha (1977) propõe que os arenitos e conglomerados sejam dividi dos em três categorias, de acordo com o seu comportamento à compressão sim ples, deformabilidade e resistência ao cisalhamento (Tabela 59).

De imediato, a partir do exame da Tabela 59, nota-se que os Areni tos Caiuä enquadram-se na categoria de "Resistência baixa", quanto à coesão, mas curiosamente possuem "Resistência elevada" quanto ao ângulo de atrito interno.

Considerando-se o mödulo de elasticidade secante $E_{40}$, para os are nitos ensalados, vê-se que eles se incluem na categoria de materiais de "baixa" e "média" resistência, com 2 casos anômalos de "alta resistência", devidos a Módulos de 115.940 e $112.360 \mathrm{~kg} / \mathrm{cm}^{2}$. 


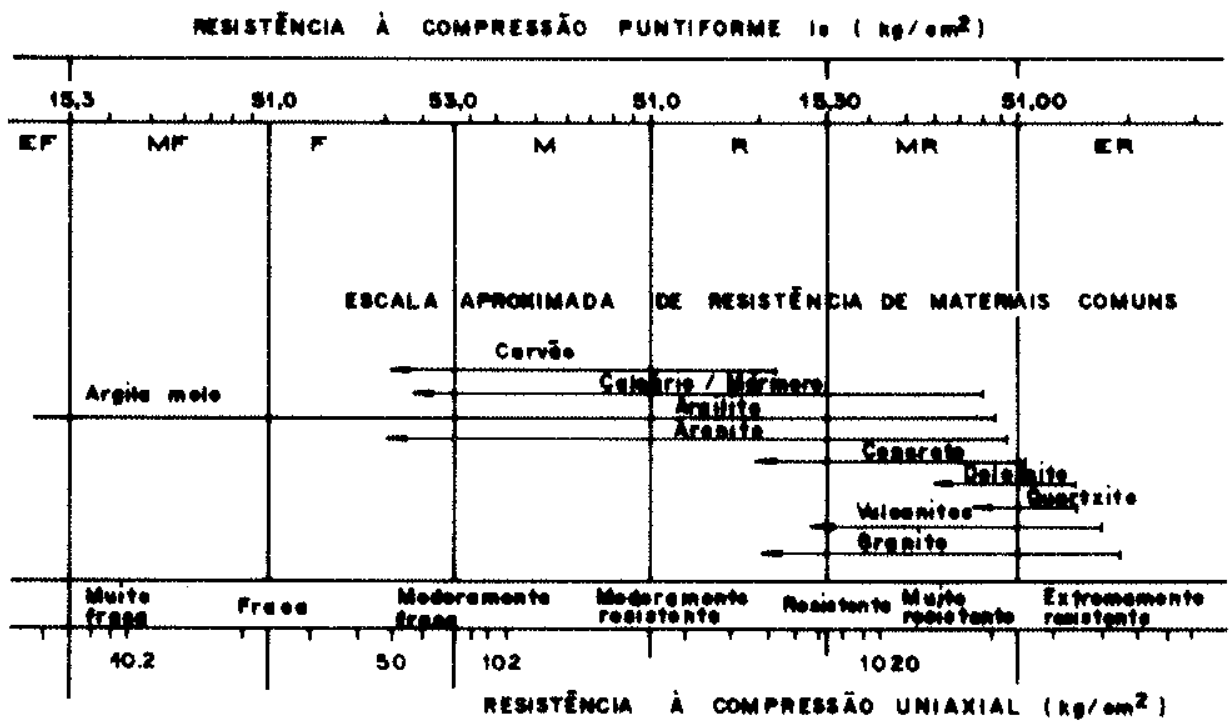

F16. 11 - COMRELAÇÃo ENTRE AS RESISTẼNCIAS A conPREsSÃo SIMPLES

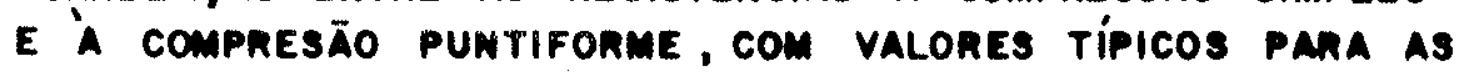
ROCHAS MAIS COAUNS (SEO. WILSON, BROCHT E FRANKLIM (1977) MOD. ). 
Tabela 59

Resistência à compressão simples, mödulo de deformabilidade e resistência ao cisalhamento de solos e rochas

(Rocha, 1977)

\begin{tabular}{|c|c|c|c|c|}
\hline $\begin{array}{l}\text { Tipo de arenito } \\
\text { ou conglomerado }\end{array}$ & $\begin{array}{l}\text { Resistência à } \\
\text { compressäo } \\
\text { simples }{ }^{\sigma c} \\
\quad\left(\mathrm{Kg} / \mathrm{cm}^{2}\right)\end{array}$ & $\begin{array}{l}\text { Mödulo de De- } \\
\text { formabi l idade } \\
\left(10^{3} \mathrm{Kg} / \mathrm{cm}^{2}\right)\end{array}$ & $\begin{array}{l}\text { Resistênci } \\
\text { coesão }{ }^{\mathrm{c}} \\
\left(\mathrm{Kg} / \mathrm{cm}^{2}\right)\end{array}$ & $\begin{array}{l}\text { ao cisalhamento } \\
\text { Angulo de atri } \\
\text { to interno }\left(^{\circ}\right)\end{array}$ \\
\hline $\begin{array}{l}\text { Resistência } \\
\text { baixa }\end{array}$ & $20-120$ & $5-40$ & $5-30$ & $30-40$ \\
\hline $\begin{array}{l}\text { Resistência } \\
\text { mëdia }\end{array}$ & $120-400$ & $40-100$ & $30-80$ & $40-50$ \\
\hline $\begin{array}{l}\text { Resistência } \\
\text { elevada }\end{array}$ & $400-1500$ & $100-600$ & $80-160$ & $50-65$ \\
\hline
\end{tabular}

Na figura nümero 62, vê-se uma proposta de Stapledon para a classificação de materiais rochosos, baseada na resistência à compressão simples. Se admitirmos os valores de Rocha, concluímos que os materiais de baixa resistência englobam os materiais muito fracos, fracos e medianamente resistentes, sendo que para esses ültimos o valor inferior são $200 \mathrm{Kg} / \mathrm{cm}^{2}$, no qual estão incluídos tipos mais alterados de granitos, basaltos e gnaisses. 0 autor esclarece que na categoria "muito fraco", hä alguma superposição da resistência com solos muito coesivos, como algumas argilas secas, o que è compreensível, uma vez que aí jä se começa a penetrar no domínio dos solos,

Pode-se verificar que hä grande concordância entre os limites apre sentados por Rocha (1977) e esses sugeridos por Stapledon. Vemos que a variação proposta para os arenitos, de modo geral, possibilita incluí-los nas faixas desde "muito fracos" atë "resistentes". 
Figura 62

Classificação de materiais rochosos, baseada na resistência à compressão simples, Rc (Stapledon, mod.)

Variação da resistência

à compressão simples (1)
Variação da resistência de algumas rochas, e do concreto

Termo

Símbolo Rc

$$
\left(\mathrm{kg} / \mathrm{cm}^{2}\right)
$$

Muito fraco(2) MF $\quad<70$

Fraco F $70-200$

Medianamente resistente MR $\quad 200-700$

Resistente R $\quad 700-1400$

Muito

resistente $M T R>1400$
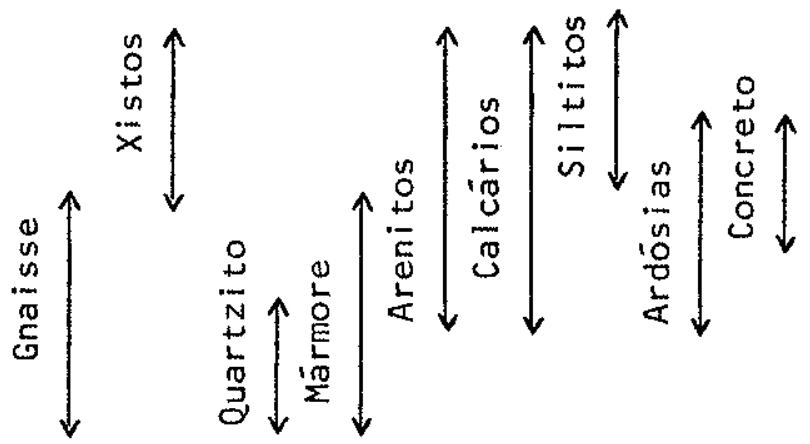

(1) Testes segundo as Normas Australianas. Para rochas com anisotropia pla nar, o eixo maior das amostras normal aos planos de "fabric".

(2) Nesta categoria, hã alguma superposição da resistência com solos muito coesivos, como algumas argilas secas. Materiais distintos pela imersão em ãgua, após o que os solos podem ser remoldados.

Na Figura 63 de autoria de Rocha (1977) pode-se verificar o inter valo das variações de alguns parämetros geomecânicos como a deformabilidade $\left(E_{r}\right)$, resistência à compressão simples $\left(\sigma_{c}\right)$, coesão $(c)$ e ângulo de atrito $(\phi)$, para solos e rochas. Nela, vê-se que algumas rochas de mais baixa resistência, ainda que decompostas, apresentam mödulos de deformabilidade (E) superiores aos solos, mesmo considerando-se o fato desses terem sido ensaiados impedindo-se as deformaçöes laterais. De uma maneira geral, os valores mäximos de $E$, são da ordem de $500 \mathrm{~kg} / \mathrm{cm}^{2}$ e $4000 \mathrm{~kg} / \mathrm{cm}^{2}$, para solos e rochas, respectivamente. Os valores mais baixos da coesão das rochas são quase coincidentes com os mäximos de argilas duras, sendo $3 \mathrm{~kg} / \mathrm{cm}^{2}$ - ponto limítrofe dessa propriedade, enquanto que os ângulos de atrito interno de alguns solos são superiores aos de algumas rochas. 0 valor de $20 \mathrm{~kg} / \mathrm{cm}^{2}$ limita, para menos e mais, os indices da resistência à compressão simples de solos e rochas, respectivamente. Rocha argumenta ainda que ê prudente adotar-se o valor limite de $200 \mathrm{~kg} / \mathrm{cm}^{2}$ para a resistência de ro 
chas de baixa resistência, seja pelo fato de que representa uma fronteira real, a partir da qual as rochas apresentam um comportamento marcadamente distinto, mas também por estar de acordo com a "Classificação Bãsica de Ma ciços Rochosos", adotada pela Sociedade Internacional de Mecânica das Rochas, que também admi te serem as rochas de muito baixa resistência aquelas com yalores da resistência à compressão simples inferiores a $60 \mathrm{Kg} / \mathrm{cm}^{2}$.

Pode-se considerar, adotandomse ainda as ponderações de Rocha, que as rochas de baixa resistência possuem resistência à compressão simples variävel entre 20 e $200 \mathrm{~kg} / \mathrm{cm}^{2}$.

Quanto à deformabilidade em si, ê possível correlacionä-la com a compressão simples, pela expressão

$$
E_{r}=200 \sigma c
$$

Sendo $\sigma_{c}$ variável, como jä se viu, entre 20 e $200 \mathrm{~kg} / \mathrm{cm}^{2}$, os mödu los de deformabilidade das rochas de baixa resistência apresentam-se na faixa de 400 a $4000 \mathrm{~kg} / \mathrm{cm}^{2}$. Näo se pode todavia esquecer que as deformabilidades da rocha em si podem ser muito maiores que as dos maciços correspondentes, pois na sua determinação não são, necessariamente, representadas as descontinuidades de toda espêcie existente no maciço.

Stagg \& Zienkiewicz (1968), apresentam uma correlação entre a rem sistência à compressão simples e o mödulo de Young ou mödulo de elasticida de para diversas rochas, inclusive arenitos (Figura 64). Atravēs dela, verifica-se que as rochas de baixa resistência possuem valores da relação $\frac{E}{\sigma c}$ de 200:1 para menos, incluindo-se nesta faixa a maior parte dos folhe Thos arenitos e xistos com xistosidade horizontal. Os gnaisses, quartzitos, dolomitos, calcários e basaltos podem apresentar, atravēs de, exemplares mais alterados, relações $\frac{E}{\sigma c}$ pröximas de 200:1. Jä muitos dolomitos e calcärios, märmores, quartzitos e xistos com xistosidade muito inclinada relativamente ã aplicação do esforço e muitos gnaisses, exibem relações $\frac{E}{\sigma c}$ quase sempre de médias a altas, sendo esses ültimos valores da ordem de 500:1, ou mesmo malores.

E possivel notar-se que os arenitos apresentam valores do módulo de deformabilidade desde muito baixos (pröximos de $25000 \mathrm{~kg} / \mathrm{cm}^{2}$ ) até muito altos $\left(400000 \mathrm{~kg} / \mathrm{cm}^{2}\right)$, possuindo, no entanto, relaçōes $\frac{E}{\sigma c}$ de valores 
Figura 63

Variações de parâmetros geomecânicos para solos e rochas (Rocha, 1977)

a) Mödulo de Deformabilidade

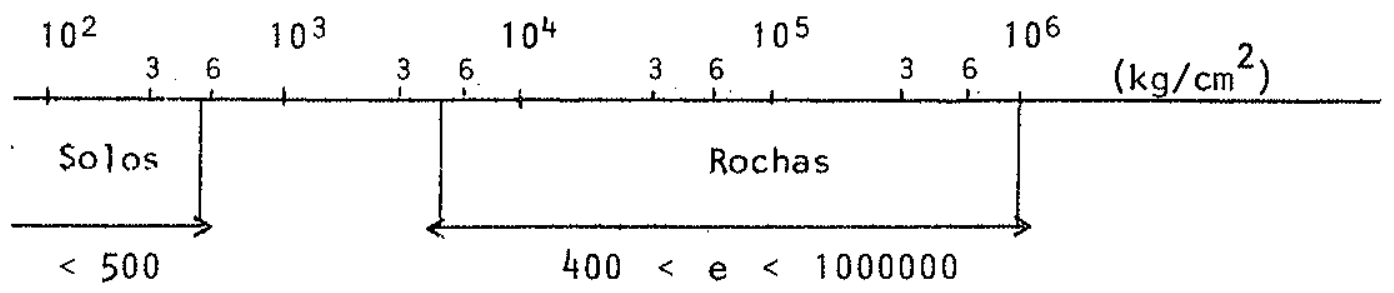

b) Coesão

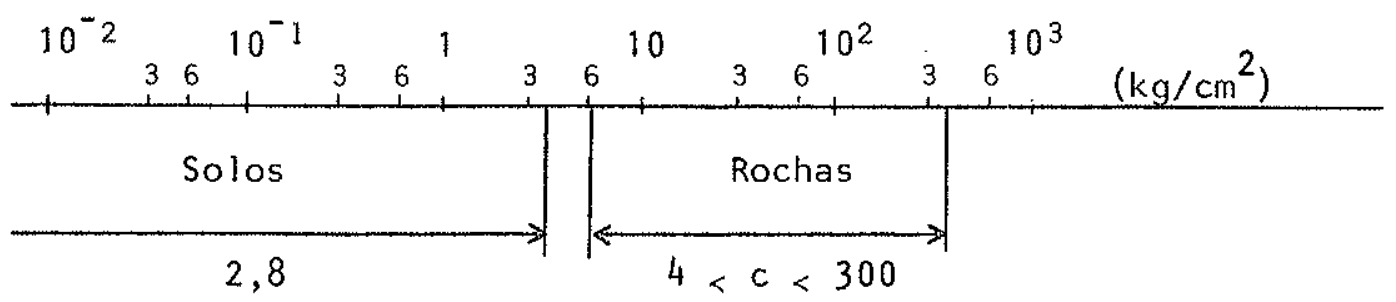

c) Ângulo de Atrito

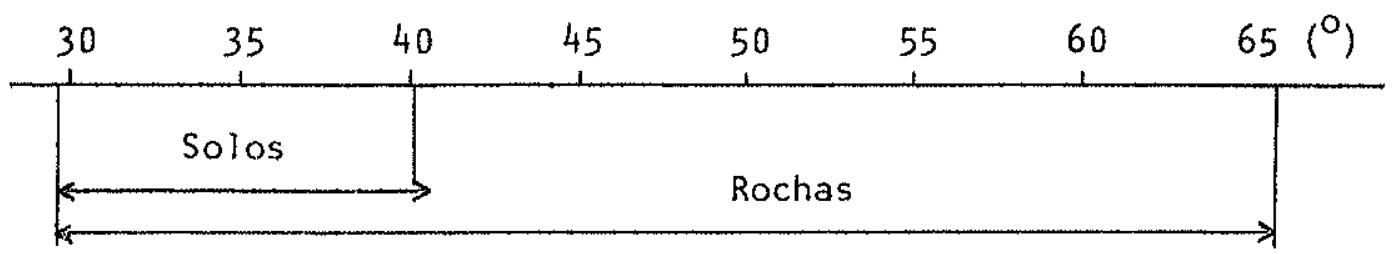

d) Resistência à Compressão Uniaxial

$\underset{\text { Solos }}{\stackrel{10^{-2} 6^{10^{-1}} 36^{1} 36^{10} 36^{10^{2}}+36^{10^{3}}}{+36^{10^{4}}\left(\mathrm{~kg} / \mathrm{cm}^{2}\right)}}$




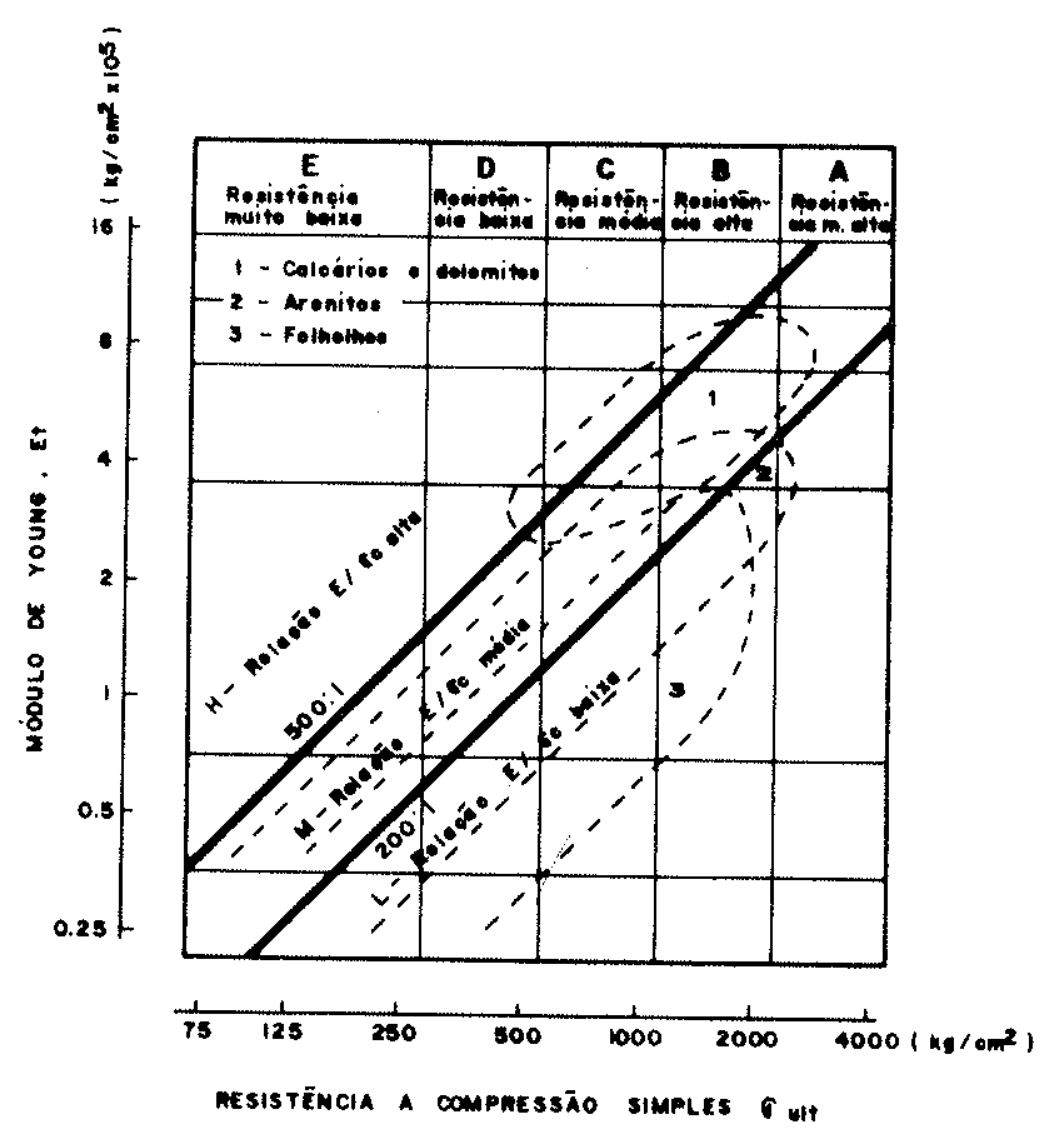

F16. 64 - ClASSIFICAÇĀO gEOTÉCNICA PARA ROCHAS INTACTAS. Et = MÓdULO TANGENTE A $50 \%$ DA RESISTÊNCIA MÁXIMA (SEG. STAGG a ZIENKIE WICZ, MOD. ). 
mëdios a baixos, ou seja, sempre abaixo de 500. Examinando-se a tabela à luz dessas considerações, vê-se que dos arenitos Caiuä ensaiados, apenas 6 apresentaram relação $\frac{E}{\sigma_{c}}$ maiores que 500 , estando todos os outros valores abaixo desse valor, alguns inclusive muito abaixo.

\section{Aplicabilidade como fundação}

Sabe-se que a natureza das solicitações impostas aos materiais de fundação, excetuando-se o estado de tensões (inicial ou residual) pode ser descrito como segue:

1) Escavação e preparação da rocha, quando esta ë submetida a desmonte por explosivos que transmitem elevadas tensões instantâneas de tração e compressão;

2) Peso de estrutura sobreposta, que transmite ao maciço tensões cuja distribulção, idealmente deve ser o mais uniforme possivel. Neste caso, o comportamento diferencial do maciço é mais importante que o módulo em valor absoluto da rocha, pois as concentrações de tensões são inconve nientes.

3) Resultante do peso da obra mais o empuxo da ägua. A ação das tensões cisalhamento transmitidas aos maciços de fundações pelas barragens de concreto são favorecidas pelas subpressöes e pressões neutras que agem nas fundações. A função de resistir a tais solicitações, bem como as de tração, compressão, etc, estarã a cargo do maciço rochoso e as carac terísticas de sua distribuição fica por conta do padrão das descontinuidades.

Interessa também, no caso de fundações, saber do comportamento da rocha exposta pelas escavaçöes, face às condições intempëricas, durante o lapso de tempo após abertura-concretagem.

Segundo Rocha (1977), é possível estabelecer o grau de influência do Módulo de Deformabilidade do maciço de fundação no estado de tensões das obras nele apoiadas. Considerando-se os nödulos de deformabilidade do concreto $\left(E_{c}\right)$ e do maciço rochoso $\left(E_{m}\right)$, chega-se à uma avaliação do grau de influência das deformações de uma fundação constituída de rocha de baixa resistência. Rocha (1977) indica de maneira qualitativa esta influên cia, admitindo que somente para valores de $\frac{E_{m}}{E_{C}}<\frac{1}{4}$ ela ë significati- 
va (Figura 63). Isto significa em verdade mödulos $E_{m}<60000 \mathrm{~kg} / \mathrm{cm}^{2}$, em se considerando $E_{c}$ da ordem de $240.000 \mathrm{~kg} / \mathrm{cm}^{2}$. Como os mödulos $E$ das rochas de baixa resistência, da ordem de $40000 \mathrm{~kg} / \mathrm{cm}^{2}$ e lembrando-se que para mödulos menores que $30000 \mathrm{~kg} / \mathrm{cm}^{2}$ jä ë grande a influência da deformabili idade no estado de tensões, conclui-se que torna-se bastante problemática a fundação de grandes estruturas de concreto em materiais cujos mödulos tenham aqueles valores.

Figura 65

Grau de Influência da Deformabilidade

(Seg. Rocha, 1977, mod.)

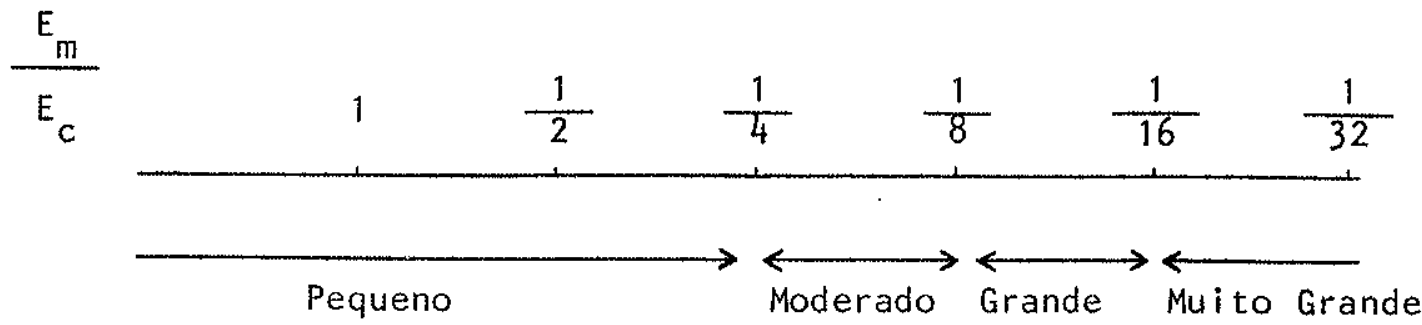

Ao se verificar os resultados dos ensaios de deformabilidade com os Arenitos Caiuä, notaremos que (Tabela nümero 55) poucos exemplares (ape nas 3) obedecem tal condição. Todavia, è necessärio lembrar-se de que os nödulos obtidos a partir de ensaios com corpos de prova e não "in situ", conduzem sempre a valores maiores que os reais, pqis näo levam em conta a influencia das descontinuidades existentes normalmente nos maciços. Considerando no entanto que há registros de que a relação entre os mödulos de deformabilidade do maciço rochoso e do material rocha $\frac{\mathrm{Em}}{\mathrm{Er}}$ pode ser de $\frac{1}{7,6}$, para o caso de arenitos (Rocha, 1977), conclui-se de imediato que, mesmo os exemplares que apresentaram valores mais altos de $E$ poderão ter um comportamento a ser meticulosamente esclarecido, se sujeitos a ação de cargas elevadas de estruturas.

Naturalmente, há que considerar que os esforços, relativamente à atitude das descontinuidades e plano de acamamento têm influência decis va na grandeza das deformações, o que evidentemente deve ser levado em con ta na resolução de qualquer problema prätico envolvendo os Arenitos Caiuä com fundação para estruturas.

Examine-se agora o parâmetro resistência: Rocha (1977) diz que, 
admitindo a lel de Coulomb e a isotropia, e adotando-se para o ângulo de atrito o valor médio do intervalo de variação dos seus valores, pode-se obter o valor da coesão pela correlação

$$
c=\frac{1}{4} \sigma c
$$

Aquele autor ressalva que, no geral, a resistência ao cisalhamen to dos maciços ê tanto menos influenciada pelo fraturamento quanto menor for a resistência da rocha, ou seja, as descontinuidades deixam de ser in fluentes na medida em que o material começa a confundir-se com solo. No entanto, mesmo para rocha de baixa resistência essa influência não pode ser desprezada, ainda que se leve em conta as dificuldades de se conside rar o fraturamento, a não ser em casos dele ser contínuo e persistente.

Ao se adotar as ponderaçôes de Rocha relativamente à correlação entre a coesão $c$ e a resistência à compressão simples $\sigma c$, vê-se que os va lores da coesão, para os Arenitos Caiuä, ao se manipular os dados da Tabe la 55, são em regra superiores aos obtidos nos ensaios triaxiais (Figuras nümeros 56 e 57, Tabela nümero 56).

Os dados obtidos nos ensaios de deformabilidade e resistência ã compressão simples, permitiram traçar um zoneamento preliminar do maciço de Arenitos Caiuä no local de amostragem 111 , mostrado na figura 66. Tem-se observado que esta compartimentação ê vâlida para ocorrências também acima do nível do Rio Paranapanema.

\section{Perfurabilidade dos Arenitos Caiuã}

Analisarmse-á, a seguir, a atuação das rochas estudadas quanto à perfurabilidade durante as sondagens de reconhecimento.

Foram realizados os seguintes tipos de sondagens nos Arenitos Caiuä, dos locais de amostragem I., III, IV e V.

1) Sondagens de percussão pelo método tradicional ou seja, alter nando-se a introdução no terreno do barrilete amostrador SPT (Standart Penetration Test), de diâmetros externo e interno iguais respectivamente a $2^{\prime \prime}$ e $13 / 8^{\prime \prime}$ e do trëpano de lavagem de diâmetro $23 / 8^{\prime \prime}$, abaixo do nível $d^{\prime}$ ägua, sendo o furo geralmente iniciado com trado cavadeira de 4 ".

2) Sondagens rotativas com coroas de diamante $H$ (diâmetro dos 


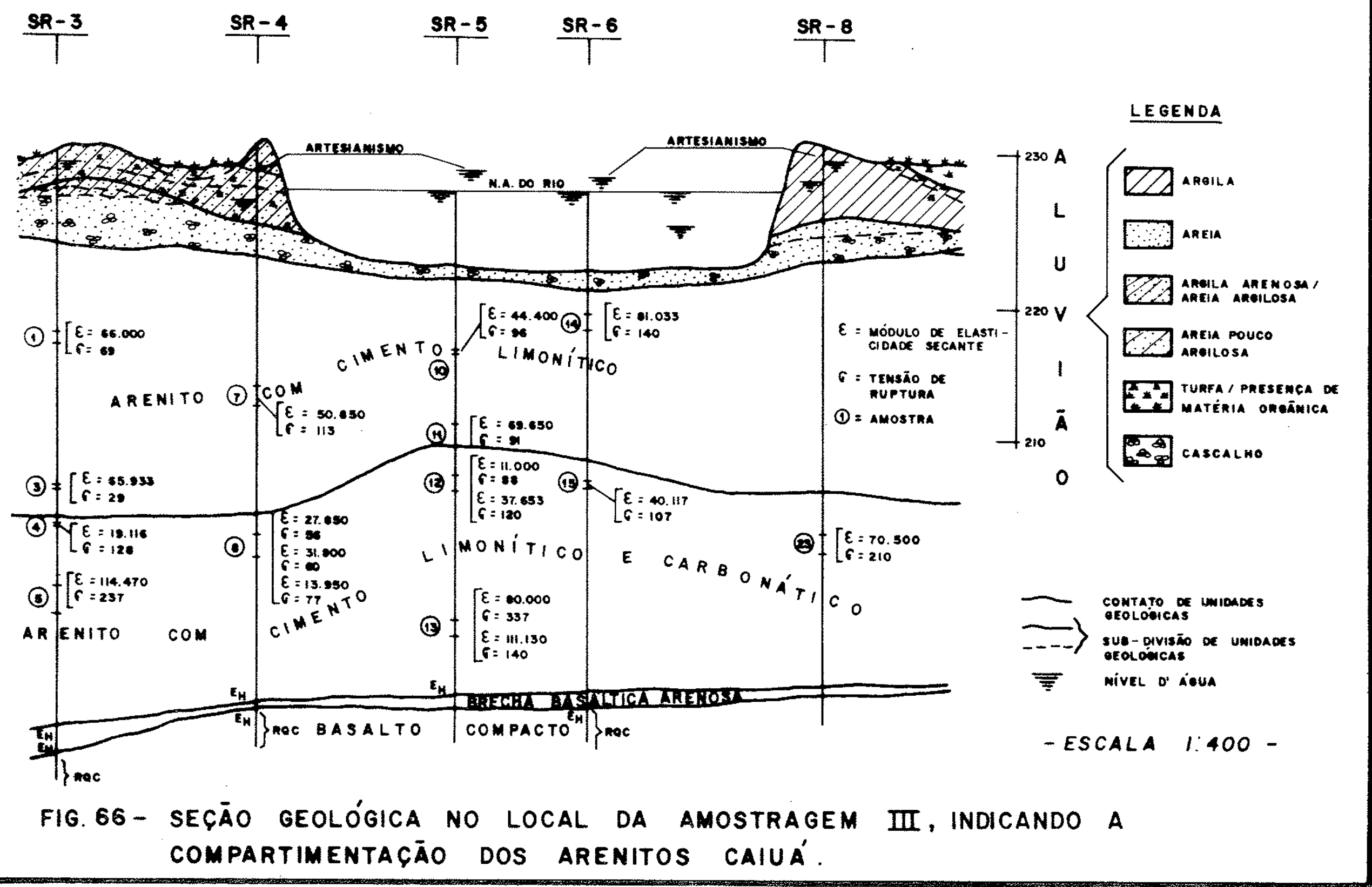


testemunhos igual a $76,2 \mathrm{~mm})$,

As sondagens a percussão limitarammse âs faixas mais superficiais, onde predomina o arenito limonitico friävel, que frequentemente se confunde com o respectivo "solo de alteração". Nesses materiais, a penetra ção ao barrilete amostrador foi difícll, o que se justifica pela alta percentagem de areia que constitui o arenito. Os índices de resistência à penetração (IRP) foram sempre altos $(10$ golpes para a penetração de 2,3 ou $4 \mathrm{~cm} ; 30$ golpes para a penetração de 12 ou $15 \mathrm{~cm}$; e 20 golpes para a penetração de $8 \mathrm{~cm}$ do barrilete amostrador) valores esses bastante comuns nos ensaios de penetraçāo. No entanto, o aprofundamento dos furos usando-se o trēpano de lavagem e água de circulação sempre foi bastante facilitado, o que vem provar que o efei to da ägua associado a esforços mecânicos (a operação de forçar o trêpano para dentro do furo, visando aprofundä-lo) provo ca a destruição do cimento, destruindo a tênue ligação dos grãos pelo menos nos tipos mais friãveis, o que jã não acontece nas operações com o bar rilete SPT, as quais, como sabemos, são realizadas a seco.

Quanto ãs sondagens rotativas, notamos que os arenitos em geral proporcionam boas recuperações (relação entre o comprimento dos testemunhos obtidos e o comprimento do amostrador, em percentagem), geralmente a cima de 75\%, com excessão de poucos trechos, quase sempre na parte superior do maciço arenítico ou prỏximo ao contato com a brecha basältica infe rior, onde, em algumas sondagens se constataram valores de $25 \%$. Valores altos da recuperação como os descritos explicam-se, em parte, pela utiliza ção de equipamento adequado (corôas com saídas d'ägua frontais; barriletes duplo-livres) e operações de sondagens conduzidas com bastante cuidado.

Deve-se registrar no entanto que, a contagem de fraturas por metro que possibilitaria o estabelecimento de classes de arenito segundo as descontinuidades, visando subsídios para a sua caracterização geotēcnica , fica em nosso entender prejudicada, pois as operações de sondagem provocam a separação dos alguns planos de acamamento, mascarando o verdadeiro carā ter das descontinuidades, Este fato aliâs deve ocorrer nas rochas sedimentares cujos planos de acamamento sejam facilmente separáveis. E nossa opinião que o verdadeiro estabelecimento do parâmetro fraturas/metro seja efe tivado a partir de afloramentos ou preferentemente escavações, onde não haverả aquela possibilidade de confusão.

Devemos ainda considerar o comportamento dos arenitos Caiuä nos ensaios de perda d'ägua sob pressão, realizados durante as sondagens rotativas. Recordemos que tais testes consistem na injeção de ägua sob pressão 
em determinado trecho de comprimento conhecido do furo, isolado por obtura dores, e na medição consequente da quantidade de ägua injetada durante um intervalo de tempo estabelecido. Isto nos possibilita a obtenção dos parâmetros "Perda d'ägua especifica" PE, medido em $1 \mathrm{itros} / \mathrm{min} \cdot \mathrm{m} \cdot \mathrm{kg} / \mathrm{cm}^{2}$, e do "Coeficiente de permeabllidade equivalente" $\mathrm{k}$, cuja unidade é $\mathrm{cm} / \mathrm{s}$. Nos ensaios realizados notou-se que os valores de PE e $k$ foram baixos, respectivamente $<2$ e $10^{-4}$ ou $10^{-5}$. Valores maiores que estes ocorreram em trechos determinados e particularmente próximo ao contato com o basalto, como na sondagem SR-8, onde entre as altitudes 202 e $205 \mathrm{~m}$ (contato basalto/are nito à altitude $200 \mathrm{~m}$ ) observou-se uma vazäo correspondente a $86,7 \mathrm{1} / \mathrm{min}$, igual à vazão total de bomba usada, sem terrse atingido a pressão mäxima especificada para a profundidade em questão $(37$ a $40 \mathrm{~m})$.

0 exposto nos faz concluir que, de uma maneira geral não se deve esperar grandes aportes de âgua durante as escavações em arenitos caiuä ou altos valores de subpressões sob barragens de concreto, a menos de hor zontes perfeitamente identificáveis. A condutividade hidräulica pelas fraturas dos arenitos Caiuä ẻ portanto baixa, a menos das excessões localizadas, como o ë tambëm a permeabilidade de porosidade já comentada anteriormente. No entanto este quadro deve ser restrito a ambientes localizados, não devendo ser extrapolado para âmbitos regionais, jä que neste caso influem outros parâmetros, de natureza hidrolögica, näo levadas em considera ção aqui.

\section{Aplicação como enrocamentos}

As funções mais comuns dos materiais rochosos como enrocamentos e "rip-raps" $\vec{e}$ a de proteger aterros, barragens e outras estruturas suje tos ã ação das äguas, contra a erosão e o impacto das ondas; constituir camadas de transiçẫo de granulometria decrescente entre o enrocamento externo e o aterro compactado, a fim de prevenir o arraste de particulas; constituir o corpo de ensecadeiras e o maciço de barragens de enrocamento quando se conclui que é vantajoso, têcnica e economicamente, relativamente aos maciços de terra compactada,

Com essas funções, os materiais pëtreos estarão sujeitos a diver sas solicltações como: ciclos de saturação e secagem, devido às variações do nível d'ägua; impacto da açâo mecânịca das ondas; cargas concentradas no contato entre cada um dos blocos componentes do maciço, e alterabilidade devido aos agentes de intemperismo. 
Considerando-se este tipo de aplicação, deve-se fazer uma distin ção entre enrocamentos e "rip-raps", jä que as especificações de projeto e construtivas são em geral diferentes para os casos. Dä-se o nome de enroca mento aos maciços constituldos quase que exclusivamerite de blocos de rocha, enquanto os "rip-raps" são camadas protetoras de aterros, geralmente de pequena espessura.

A experiência tem demonstrado que o sucesso de uma estrutura de enrocamento depende mul to mais das especificações e mêtodos construtivos do que das hipöteses de projeto.

Critërios gerais para a escolha dos materiais naturais

\section{Enrocamentos}

Para os enrocamentos, as especificações procuram enfatizar maior rigor para seleção dos materiais colocados na parte externa dos maciços.

Os aspectos mais relevantes são aqueles referentes à sanidade, dureza, gradação, deformabilidade e resistência dos materiais empregados.

No que tange ã sanidade, ê recomendävel que as rochas sejam as mais sãs possiveis.

No entanto, atualmente, tolera-se o uso de materiais com caracte rísticas menos aceitäveis, atravēs de uma aplicação seletiva dos diferen tes tipos em diferentes zonas do maciço.

No caso de materiais pêtreos de qualidade duvidosa, é aconselhável avaliar o seu comportamento pela construção de enrocamentos experimen tais, se for economicamente viävel.

A resistência ao cisalhamento e a compressibilidade do enrocamen to dependem de alguns fatores interrelaclonados, e que são (Golzẽ, 1977):

a) Indice de vazios e densidadr relativa da massa granular. Uma vez fixadas as outras variáveis (descritas a seguir), uma diminuição do in dice de vazios e o aumento da densidade relativa conduzem a um aumento do ângulo de atrito interno do material.

b) Caracteristicas físicas das particulas de rocha. Os constituintes minerais afetam o atrito entre blocos individuais e, de alguma for 
ma, o atrito da massa inteira. A litologia e as características

estruturais das partículas de rocha influenciam a resistência dos fragmentos indi viduais e a magnitude da quebra e esmagamento dos cantos dos blocos sob carregamento.

c) A gradação, no sentịdo que um material bem graduado terā um ângulo de atrito mais alto relativamente aquele mais uniforme. Alguns estu dos no entanto, mostraram que pode ocorrer o conträrio, a baixas densidades. Daí ser necessârio, para se obter os valores mais altos da resistên cia ao císalhamento, compactar o material à sua mäxima densidade.

d) Tamanho dos fragmentos - A quebra das partículas sob carregamento aumentaria com o tamanho das partículas, talvez devido ao grande nü mero de fendas e fraturas presentes nas partículas maiores. A resistência ao cisalhamento dos materiais granulares diminui multo com o aumento da quebra e esmagamento nos pontos de contato entre os fragmentos.

e) Forma dos fragmentos - Fixando-se os outros parámetros inter venientes, o ângulo de atrito interno de um material granular anguloso $\overrightarrow{\mathrm{e}}$ maior do que aquele de material composto de partículas arredondadas.

f) Teor de umidade - Partículas de rochas umidecidas são muito mais fracas do que as secas. O enfraquecimento devido ao teor de umidade nos pontos de contato aumenta a quebra e o esmagamento nos pontos de conta to, afetando a resistência ao cisalhamento da massa granular.

g) Pressão de confinamento - A resistência ao cisalhamento dimi nui com o decrëscimo da pressão confinante na massa granular. No entanto, sabe-se que, para pressões confinantes acima de $45 \mathrm{~kg} / \mathrm{cm}^{2}$, a diminuição do ângulo de atrito interno não seria apreciâvel, e consequentemente a envoltöria de Mohr no plano de ruptura principal teria diferentes inclinações para baixos valores da tensão normal, com valores altos da tangente, pröxi mo ao zero, diminuindo gradualmente com o aumento das tensões normais.

0 assunto relativo ã gradação dos fragmentos de rocha componentes do enrocamento foi, no passado, defendido por opiniöes divergentes. Acreditavam uns que, o maciço deveria ser construído por blocos individuais de tamanho razoavelmente uniforme, cada um tangenciando o outro, constituindo um arranjo que se poderia chamar "rocha-amrocha". Argumentava-se que fragmentos de diferentes tamanhos causariam recalques excessivos e de siguais, e que, ao conträrio, selecionando-se amostras de tamanhos razoavelmente uniformes, seria extremamente difícil fazer, através de um carregamento adicional, com que um fragmento qualquer ocupasse os vazios exis 
tentes na massa. Blocos grandes de rocha imersos em cascalho ou areia seriam inconvenientes, pois eles poderiam acomodar-se dentro da massa, deslo cando os grãos e fragmentos menores.

Entretanto atualmente prevalece a opiniäo de que, uma massa não segregada com el iminação do excesso de finos, poderä resultar no mals alto grau de contato "rocha-a-rocha", levando a um enrocamento de maior densida de possivel, originando ainda vazios suficientes para uma drenagem adequada.

Uma das sêrie implicações para a seleção dos materiais de inte resse, ê o fato de que a granulometria do produto a ser obtido ê controla da pelos padrôes de heterogeneidade da rocha e processos de desmonte, sendo que ê muito difícill, a partir do exame de testemunhos das sondagens rotativas, avallar-se como a rocha se comportarä durante o desmonte.

Ayrapetyan (1970) enumera as propriedades físicas e mecânicas das rochas e do maciço rochoso necessärias para a seleção dos materiais do enrocamento.

Entre as propriedades físicas, cita o peso específico natural, massa especifica aparente, e porosidade; das mecânicas, menciona a resistência à compressão simples no estado natural bem como após congelamento (este ültimo parâmetro não interessa determinar, para as barragens brasileiras, jā que não ocorrem aqui condições climäticas tão rigorosas). E con veniente tambëm a determinação da deformabilidade e da resistência ao cisa thamento seja da rocha ou do conjunto de fragmentos que vem a se constituir maciço propriamente dito.

Na figura nümero 67 , vêem se as faixas que possibilitam, segundo a Golzé (1977), a aceitação ou exclusão de determinados materiais pétreos, levando-se em consideração algumas de suas propriedades físicas como:

a) Resistência ã compressão simples

b) Absorção d'ägua

c) Peso específico dos constituintes,

Marsal (1975) responsävel pela execução de ensaios triaxiais com enrocamentos em equipamentos de grandes dimensões, fez as seguintes observações, quando à colocação de materiais pêtreos nos maciços, graças ás con clusões por ele obtidas nos ensaios: 

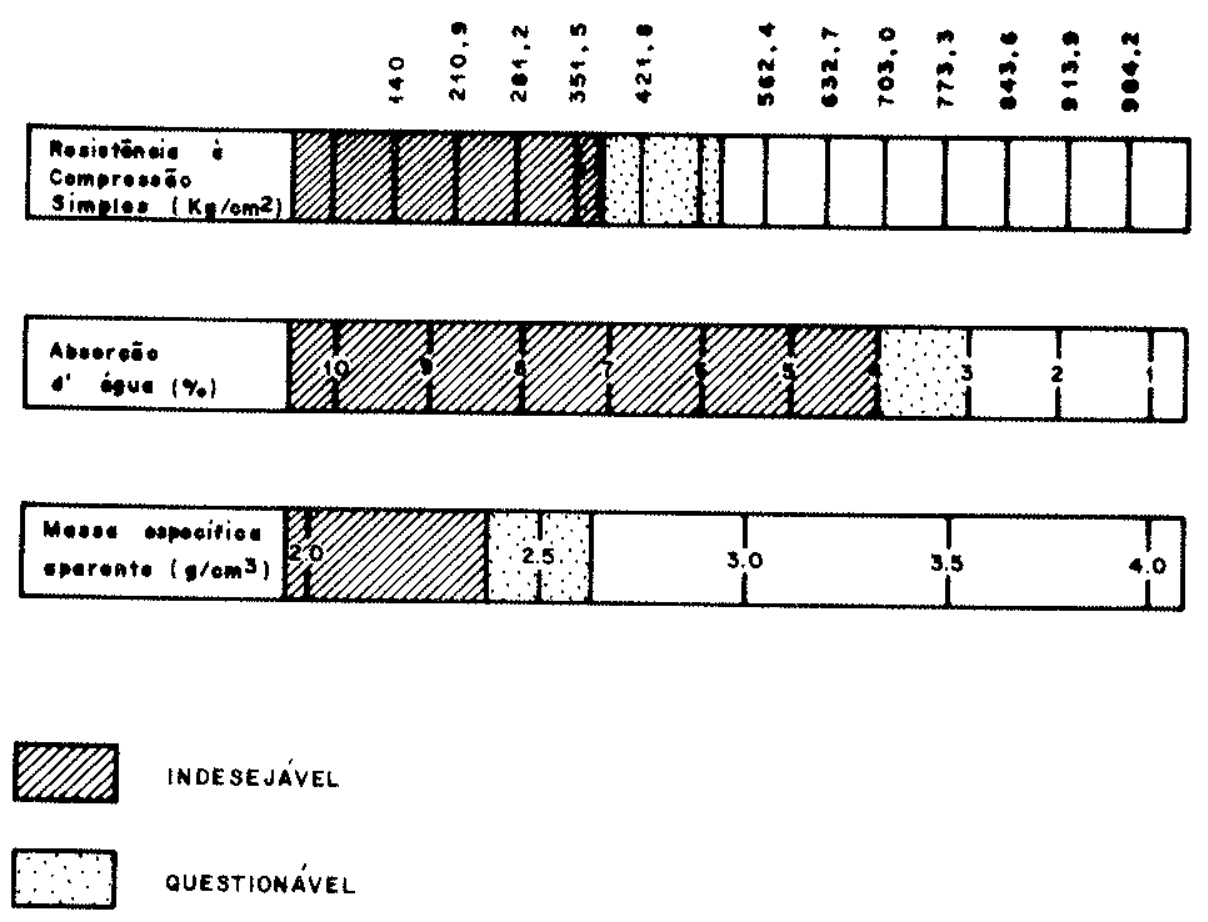

$\square \infty \mathrm{m}$

FI6. 67 - MÉtodo PADRÃo PARA AVALIAR - SE a ADEQUabILIDAdE de UM MATERIAL PARA "RIP - RAP" (SE6. COLZE, 1077 MOD.). 
a) As forças de contato são menores em um material relativamente bem graduado (Coeficiente de não uniformidade $>10$ ), do que em outro uniforme; portanto, em aterros feitos com material bem graduado, para a mesma qualidade da rocha, a ruptura dos grãos tem um valor baixo e o conjunto $\ddot{e}$ consequentemente menos compressivel;

b) Para a mesma energla de compactação, o material bem graduado adquire uma densidade relativa superior à do uniforme, o que conduz a que a resistência ao cisalhamento deste ültimo seja menor. Deve-se registrar as dificuldades que, existem no controle da composição granulomëtrica de um enrocamento produzido pelo desmonte com explosivos na pedreira, a menos que o fraturamento natural da rocha favoreça a obtenção de um material bem graduado.

"Rip-Raps"

No caso de "rip-raps", as normas geralmente exigem que uma das dimensões dos blocos não seja maior que 3 vezes as outras duas e que os fragmentos ou blocos sejam angulares para possuirem maior resisténcia ao deslocamento, Rochas igneas são aceitäveis e quanto aos sedimentos devem ser considerados apenas os arenitos bem cimentados e maciços.

Golzê (1977) propõe que a gradação de um "rip-rap", deve ser como a que mostra a tabela que se segue.

Tabela 60

Proposta para a graduação dos blocos em "rip-raps"

(Seg, Golzë, 1977, mod.)

\begin{tabular}{|c|c|c|c|c|c|}
\hline \multirow{2}{*}{$\begin{array}{c}\text { Espessura } \\
\text { nominal } \\
\text { do } \\
\text { "rip-rap" } \\
\text { (cm) }\end{array}$} & \multirow[t]{2}{*}{$\begin{array}{l}\text { Peso } \\
\text { mäximo } \\
(\mathrm{Kg})\end{array}$} & \multicolumn{4}{|c|}{$\begin{array}{l}\text { Gradação } \\
\text { percentagem em peso }\end{array}$} \\
\hline & & $\begin{array}{c}0,4 \\
a \\
0,8 m \\
\end{array}$ & $\begin{array}{c}0,014 \\
a \\
0,4 \mathrm{~m} \\
\end{array}$ & $\begin{array}{c}<0,014 \\
m\end{array}$ & $\begin{array}{c}\text { Areía e } \\
\text { pó de } \\
\text { rocha } \\
\end{array}$ \\
\hline 46 & 450 & - & $>75$ & Apenas & $<5$ \\
\hline 61 & 680 & - & $>11$ & para & $<11$ \\
\hline 76 & 1130 & - & $>11$ & $\begin{array}{l}\text { preencher } \\
\text { vazios entre }\end{array}$ & $<" 1$ \\
\hline 91 & 2,270 & $40-50$ & $50-60$ & $\begin{array}{l}\text { grandes } \\
\text { blocos }\end{array}$ & $<" 11$ \\
\hline
\end{tabular}


Consideraçöes sobre algumas especiflcações construtivas

Como jä frizamos, o comportamento da estrutura de enrocamento é extremamente dependente dos mëtodos construtivos. Portanto, êlícito dis correr sobre algumas das especificaçöes construtivas mais comuns.

De uma maneira geral, pode-se afirmar, que os mëtodos construtivos para aterros de enrocamento dependem em grande parte dos seguintes fatores:

a) Tipo de rocha;

b) 0 mäximo recalque tolerävel;

c) Da filosofia construtiva do empreiteiro.

Ayrapetyan (1970) esclarece que normalmente são recomendados os fragmentos provindos do desmonte de pedreiras, porém aqueles constituídos de matacões ou seixos são tambëm aceitäveis. Quanto aos do primeiro tipo, aqueles com uma relação comprimento/largura de 3 ou 4 vezes, são usualmente os melhores. A aceitabilidade da rocha para o enrocamento è necessariamente determinada pela sua resistência à compressão e â sua capacidade em preservar as propriedades no decorrer do tempo, tudo is to em consideração à altura da barragem, poșição de cada fração na seção considerada e às con dições climäticas da região.

Segundo ainda aquele autor, as resistências à compressão simples mínimas permitidas devem ser de 200 a 280,250 a 350 e 350 a $450 \mathrm{~kg} / \mathrm{cm}^{2}$, respectivamente para barragens baixas, mëdias e altas.

0 problema da seleção de rochas para barragens "super-altas" exI ge atenção especial. Sabe-se que nessas obras as cargas devidas ao peso próprio e às pressões hidrostäticas são tão grandes, que desenvolvem-se im portantes deformaçöes. Por exemplo, quando a altura é de 200 ou $300 \mathrm{~m}$, as extremidades ponteagudas dos fragmentos rochosos quebram-se facilmente sob a ação daquelas cargas, quando estão em contato; isto resulta em deslocamentos dentro do arcabouço rochoso. Eis porque rochas fracas ou alteradas devem ser evitadas, na construção desses tipos de barragens.

Caso haja cascalho disponivel no local, poderá ele ser preferido aos fragmentos de rocha, particularmente para barragens "super-altas", pro cedimento que reduzirá a quantidade de ensaios, jä que eles devem ser leva dos, em laboratörio, a cargas de ate 40 ou $60 \mathrm{~kg} / \mathrm{cm}^{2}$. Estas consideraçōes baseiam-se no fato de que as dimensóes, resistência, nümero e tipo dos con 
tatos no cascalho independerão das dimensões da seção da barragem, o que não acontece com os fragmentos de rocha.

Pode-se, de certa forma, reduzir a dois os mêtodos construtivos de barragens de enrocamento:

a) A colocação das pedras em camadas de espessuras previamente determinadas;

b) Lançamento das pedras com um equipamento mecânico adequado, como por exemplo, guindaste, que as deixa cair de uma altura considerāvel.

No primeiro caso, as camadas podem ter espessuras variäveis. Hä casos daquelas com 60 a $180 \mathrm{~cm}$, compactadas por um cilindro compactador. Ou tras vezes, usa-se determinar as espessuras como tendo 1 a 2 vezes o diâme tro mäximo da rocha, mas adotando-se espessuras nunca inferiores ao intervalo de 30 a $46 \mathrm{~cm}$.

Quanto ao segundo mêtodo, as pedras são lançadas de alturas nor malmente variando entre 15 e $45 \mathrm{~m}$. As deformaçōes características dessas barragens dependem, fundamentalmente dos seguintes fatores:

a) Resistência dos blocos de rocha;

b) Tamanho das partículas;

c) Processo de lançamento;

d) Grau de homogeneidade estrutural.

A importância de cada um deles aumenta com a altura da barragem. Grande parte da compressibilidade total desses enrocamentos sob carga è causada pela quebra dos cantos dos fragmentos.

Muitos propõem que sejam usados blocos que pesem atẻ $10 \mathrm{t}$, e que não haja mais que $5 \%$ em peso de partículas menores que $4^{\prime \prime}(\sim 10 \mathrm{~cm})$.

Alguns construtores especificam que os malores blocos devam ser colocados a jusante e os materiais mais finos depositados pröximos aos cen tros do enrocamento.

o lançamento da rocha pelo talude, a partir de uma altura considerävel, conduz inevitavelmente a uma certa percentagem de segregação, sen do que em cada camada o tamanho mëdio das partículas aumenta em profundida de, Os blocos maiores são sujeitos a quebrarem mais nos cantos, aumentando os finos e reduzindo o tempo de acamodação dos blocos. Por outro lado, a passagem de veículos na crista do enrocamento tambëm produz esmagamento e 
reduz a permeabilidade e a compresslbilidade da camada. Isto conduz a que as características de deformação de cada camada mudem de uma maneira desco nhecida na direção vertical, e que as fronteiras horizontais entre as cama das sejam planos de descontinuidade associados a condições anormais de ten sões nas adjacêncịas da membrana, quando existente, recobrindo a face de montante,

Costuma-se usar, normalmente, um processo para minimizar o efeito das acomodações excessivas nas estruturas de enrocamento. Trata-se de um procedimento atë certo ponto controvertido, que consiste em lançar potentes jatos de ägua sobre o maciço, e que teria, fundamentalmente a fun ção de amolecer os finos, de tal modo que eles sejam deslocados dos pontos de contato dos grandes blocos para os vazios entre os mesmos. Ainda, pelo fato de a resistência ã compressão dos blocos ser menor na condição de molhados do que secos, haverả maior acomodação dos mesmos durante o período construtivo, o que ê desejãvel.

Vê-se pois que a questão da seleção de materiais rochosos para enrocamento depende multo de regras fixadas empiricamente e se complica so bremaneira quando se trata de rochas sedimentares. No caso dos Arenitos Caiua preocupa a sua capacidade de auto desintegração a partir de proces sos de ciclagem ou mesmo devido a forças desenvolvidas nos contatos rocha/ rocha, comprometendo a sua resistêncla e fornecendo uma percentagem de materiais finos crescente com o evoluir do processo e inadequada de acordo com a tabela nümero 60 .

Uma sugestão vâli da para finalidades präticas è que os arenitos Caiuä sejam utilizados nos corpos das ensecadeiras onde não estejam previs tas grandes velocidades de arraste, supondo-se que os blocos de arenito comportem-se com um certo imbricamento. No caso do "rip-rap" não confinado para a proteção das ensecadeiras, o imbricamento deverá ser mantido mesmo quando as rochas forem submetidas a forças de arraste das äguas. Pode-se supor que tipos com resistência à Eompressäo simples $\sigma \mathrm{c} \geqslant 30 \mathrm{~kg} / \mathrm{cm}^{2}$ para - caso do corpo das ensecadeiras e $\sigma c \geqslant 80 \mathrm{~kg} / \mathrm{cm}^{2}$ para o caso dos "rip-raps", suportaräo as tensões de trabalho e manteräo o imbricamento necessärio. Para ambos os casos as perdas por ciclagem deveriam ser inferiores a $20 \%$ e a massa especifica aparente seca do material deverä ser de 2,0 t/ $\mathrm{m}^{3}$.

Evidentemente tais propostas estão muito aquëm dos critërios apresentados na Figura nümero 67. Todavia não deve ser esquecido que "coe- 
são cimentícial dos arenitos em estâgio de limonitização justifica a aplicação seletiva sugerida.

\section{Apl i cação como agregado para concreto}

Para esta finalidade, os agregados possuem as seguintes funções:

1) Resistir aos esforços sollcitantes, ao desgaste e ações das intempëries;

2) Reduzir as variações de volume dos componentes da mistura;

3) Contribuir para a minimização dos custos do concreto, pela utilizaçâo balanceada dos componentes de mistura.

A natureza das solicitações suportadas pelos agregados depende da finalidade a que se destina a estrutura, e de modo geral são:

1) Atrito e impacto - Desde a fase inicial de mistura em betone ra atē o adensamento felto por meio de soquetes e vibradores;

2) Tração ou compressão - Em obras de grande vulto, onde os agre gados são submetidos ao peso da estrutura sobreposta, forçando os vinculos entre agregado-argamassa;

3) Ação do intemperismo - Secagem e umidecimento, expansão e con tração tërmica, ação química e "äguas agressivas" durante toda a vida da obra.

Sublinhe-se a importância do estado de alteração do agregado com as características de aderência e adesividade a ligantes hidräulicos e betuminosos. A integridade da estrutura da rocha depende da eficiencia desta ligação. Os agregados de rochas semi-alteradas ou alteradas podem conter hidróxidos de ferro livres ou minerais instáveis, suscetiveis de fornecer hidröxidos por limonitização, feldspatos ferruginosos ou pirita contida.

A acidificação progressiva das superfícies do agregado pelo enr quecimento de sílica e alumina, processo originado na britagem e pela ação da àgua conduz a må adesividade a curto ou mêdio prazo.

Recentemente, atravës de estudos de Farram \& Thénoz ( ), dedu ziu-se que a britagem das rochas pode aumentar a aptidão das mesmas à alté ração, pelo crescimento das superfícies de descontinuidades, inicialmente pequenas, modificondo o carâter inicial da rocha considerada. 
A textura superficial dos agregados tem decisivas implicações na durabilidade resistência, elasticidade, resistência ã abrasão, peso especí fico, taxa da alteração química e caracteristicas de adesividade. Se os po ros são abundantes e na maioria com diâmetros menores que $0,004 \mathrm{~mm}$ pode ser esperada uma menor durabilidade ao congelamento e degelo no concreto acabado, devido ao fato desses pequenos poros, graças à capilaridade absor verem completamente a ägua e conservar a saturação após os agregados serem envolvidos pela argamassa. A ăgua aprisionada aumentarả de volume, o que provocarā tensões de tração que fundirão o concreto.

Registre-se a questão da reatividade cimento-agregados, durante - processo de endurecimento do concreto. E sabido que, agregados de rochas silicosas que possuem opala ou calcedônea têm a capacidade de reagir com cimentos alcalinos, produzindo silica gel que conduz a fraturamento intensivo do concreto. As especificações do USBR (United States Bureau of Recla mation) estabelece que rochas contendo mais que $0,25 \%$ de opala, mais que $5 \%$ de calcedônia ou mais que $3 \%$ em peso de vidros vulcânicos ou tufos e ro chas vulcânicas criptocristalinas äcidas ou intermediärias poderá causar reações deletërias no concreto, a menos que seja utilizado um cimento com baixo teor de älcalis.

A presença de argilo-minerais, como a illta e Montmorillonita ẽ tambëm nociva ao concreto, jä que possuem a capacidade de se expandirem em presença da ägua, conduzindo tambëm a fissuramentos nocivos no concreto.

Levando-se em conta as restrições descritas para a fabricação de concreto, podemos concluir que os Arenitos Caiuä, de uma maneira geral, não se prestam como agregado para aquele produto, e pelas razões que se seguem:

a) Trata-se de material friảvel, portanto com grande potencialidade de liberação de grãos livres á superfície dos agregados, ou seja, a textura superficial compromete uma boa adesividade ao cimento;

b) Da sua composição mineralögica constam os minerais deletërios calcedônea e os expansivos Montmonllonita, bem como Hidröxidos de ferro;

c) Da sua britagem são originados blocos de forma inconveniente dada à influência das anisotropias existentes na rocha graças aos planos de acamamento e à geometria das fraturas, conduzindo ã produção de um concreto caro, pela utillização excessiva de cimento.

d) A resistência mecânica, representada pelo Ensaio de Resistêncla ã Abrasão Los Angeles, exige que aş perdas sejam menores que $50 \%$ (Norma American Society for Testing Materials, c 33-67, 1970). Os arenitos 
Caiuä limoníticos ensaíados apresentaram perdas variâveis entre 33,62 e $100 \%$, o que nos leva a admitir um comportamento pelo menos suspeito, dos arenitos em questão.

No entanto, os processos superponentes de limonitização graças, como sabemos, à particularidades climäticas essencialmente tropicais, devem conduzir a produtos pẻtreos de qualidades mais aceitäveis. Como exemplo, citaremos o trabalho recente de Gomes de Souza e Pinto Ferraz (1979), que considera a possibilidade de utillzação das lateritas do Maranhão como agregados para concreto. Nele, os autores revelam que, corpos de prova con fecclonados com tal material, embora com agregados que apresentaram perdas ã Abrasão Los Angeles de 37\%, apresentaram valores de tensões de ruptura, apös 28 dias, de $173 \mathrm{~kg} / \mathrm{cm}^{2}, 236 \mathrm{~kg} / \mathrm{cm}^{2}$ e $256 \mathrm{~kg} / \mathrm{cm}^{2}$, valores esses correspondentes a, respectivamente agregados sem lavagem, e com lavagem de 3,9 e 30 minutos, para eliminação do material pulverulento. 0s autores, porêm, não especificam qual a litologia ou a composição mineralógica da la terita em questão.

Jä Oliveira e Caruso (1979) apresentam resultados de ensaios efe tivados com arenitos finos e mëdios, conglomerados, siltitos argilitos concrecionados e materiais coluvionares, os 4 primeiros do Grupo Barreiras (Terciärio) e o ültimo do Quaternärio da liha de São Luiz, no Maranhão, to dos esses tipos com marcantes indícios de processos de limonitização. Corpos de prova confeccionados com o arenito mëdio ferruginoso, apresentaram, com traço $1: 4$ e fator ägua/cimenţo 0,45 , uma resistência ã compressão sim ples, apôs 28 dias, de $249,15 \mathrm{~kg} / \mathrm{cm}^{2}$, valor bastante satisfatộrio.

\section{Utilização em Obras Rodoviârias}

A rocha usada com esses propôsitos estarä sujeit ta à abrasão causada pelas forças horizontais atravës das rodas dos veículos que trafegam pelas estradas, ou dos aviões que operam nos aeroportos. 0 peso dos veículos parados produz compressão no material do pavimento, ao passo que os em movimento originam um impacto adicional estimado em $25 \%$ da carga estäti ca. Quanto mais ãspero o pavimento, maior o impacto. A resistência da rocha ao impacto ẽ a sua tenacidade.

Em geral os agregados que suportam as cargas e as transmitem ao subleito podem ser pedras britadas ou cascalhos "in natura", fragmentos de arenitos, areịa, escôria, minërio de ferro, etc, sendo as mais satisfatö- 
rias os basaltos, andesitos, diabâsio e dioritos, os arenitos geralmente têm pequena capacidade de carga, mas podem ser usados ocasionalmente em partes do pavimento onde estiverem razoavelmente afastados dos efeitos ime diatos das forças abrasivas.

Serão fornecidos a seguir, algumas das exigênclas de Especificações consagradas para o uso de pedra britada ou pedregutho britado ou não, em mistura betuminosa para pavimentos. Em primeiro lugar, a Norma DER3-547 (parcial) Departamento de Estradas de Rodagem do Estado de São Paulo:

a) Densidade do agregado: $>2,5 \mathrm{~g} / \mathrm{cm}^{3}$

b) Resistêncị à Abrasâo Los Angeles: $\leqslant 50 \% \mathrm{em}$ perda

c) Resistência ao Impacto Treton: < $30 \%$

d) Resistência à Compressão Simples: $>1400 \mathrm{~kg} / \mathrm{cm}^{2}$

A seguir, a Norma ASTM-D 692-67 (1970), parcial:

a) Resistência à Abrasão Los Angeles:

- Na superfície: $\leqslant 40 \%$ em perda

- Na base: $\quad \leqslant 50 \%$ em perda

b) Sanidade:

$12 \%$ em perda com $\mathrm{Na}_{2} \mathrm{SO}_{4}$

$18 \%$ em perda com $\mathrm{MgSO}_{4}$

Vê-se que as Especificações do DER jä invalidam a utilização dos Arenitos Caiuä britrados em pavimentos rodoviärios, em função dos resultados obtidos nos ensaios jä analisados.

No entanto, Nogami (1978) previne que tende-se, em nosso meio a um exagero no dimensionamento do projeto dos pavimentos com base principal mente na experiência alienigena, com um mëtodo desenvolvido pelo DNER (Sou $z a, 1966)$. Esclarece que for desenvolvido por Morin e Todor (1975), um mëtodo de dimensionamento baseado nas particularidades climäticas de regiões tropicais, não considerando porëm, nenhuma diferença de comportamento dos solos superficiais lateríticos ou saproliticos. Enfatiza que os Solos Late ríticos devem ser utilizados considerando-se as suas reais potencialidades o que normalmente não vem sendo feito.

Nogami (1978) examina a aplicação de diversos tipos de solos por ela chamados lateriticos. Hâ o caso dos Solos Areno-Argilosos Finos, que apesar de satisfazerem apenas parcialmente às especificações para bases e 
sub-bases, devido ã granulometria fina, indice de plasticidade e limites de liquidez acima dos valores mäximos normalizados, têm sido utilizados quando para trânsito leve a mëdio, recobertos por uma camada betuminosa in ferior a $3 \mathrm{~cm}$. A tecnologia sobre o uso desse material em pavimentação foi divulgada por Villibor (1974) e Utiyama (1977). Esses mesmos materiais fo ram usados em mais de $8000 \mathrm{~km}$ de rodovias como base de solo-cimento, obede cendo ã dosagem segundo criteerrios bảsicos desenvolvidos pela Associação Brasileira de Cimento Portland (1956). Nogami esclarece que o comportamen to dessas bases teve apreciãvel dispersäo, sendo a conclusão de que hä de se desenvolver critêrios específicos de dosagem de solo-cimento, que atendam às particularidades dos solos lateriticos.

De acordo ainda com este ültimo autor, a fração desses solos are no-argilosos que passa na peneira de $0,075 \mathrm{~mm}$ pode funcionar como filler

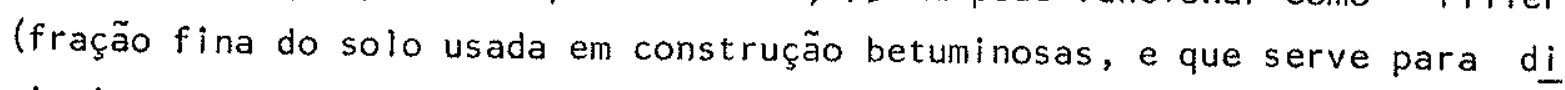
minuir os vazios da massa e enrijecer o ligante), substituindo o convencional (cal hidratada, pö de calcário, cimento portland), que custam mais caro; este material fino prërmisturado a quente obedecendo critërios do "rolled asphalt" (British Standast Institution, 1973) tem apresentado, se gundo o autor, comportamento excelente.

Nogami adverte porëm que, as características de coesão dos solos lateriticos que conferem ao mesmo um bom desempenho como pavimento, ao mes mo tempo implicam em baixa permeabilidade, tornando problemätico o uso do critërio de drenabilidade das camadas do pavimento proposto por Cedergreen (1974) para condições especîficas nos EEUU.

\section{Utilização em escavações subterrâneas}

Com esses objetivos as rochas adjacentes à escavação têm as funções de suportar as tensões do maciço situado para alëm da mesma, e ainda, total ou parcialmente as pressões internas em tüneis sob pressão hidrostātica. Normalmente, as solicitações a que estão sujeitas são trações e compressões instantâneas, devido aos processos de abertura da cavidade, ao prôprio processo de redistribuição das tensões devido ã abertura da escava ção e dos processos de intemperismo e ảguas agressivas, facilitados pelas descontinuidades das rochas.

Sabe-se que tais solicitações configuram-se pela tendêncla de diminuição da seção de projeto e pressões sobre o revestimento, quer na fa 
se construtiva ou operacional.

Cabe aqui um arrazoado a respeito do que aqui se chama, resumida mente, "revestimentos", mas que do ponto de vista da engenharia estrutural adquire conotações bem mais amplas, dentro das estruturas subterrâneas, as sociadas às obras subterrâneas, estruturas que podem ser classificadas, de forma simplificada, em funçāo de suas caracteristicas funcionais.

Assim ê que Camargo (1971) diz que se reconhecem dois tipos de estruturas: as provisőrias e as definitivas. As primeiras, se configuram em quaisquer providênclas construtivas adotadas para consolidar, conter ou escorar localmente os maciços rochosos enquanto se desenvol vem as diferentes fases da construção da obra. Não podem ser desativadas apös a realização dos revestimentos definitivos, podendo assim ser vistas como estruturas recuperāveis e estruturas incorporadas, Quanto ã participa ção do maciço rochoso no funcionamento do sistema resistente que as estruturas provisörias podem estabelecer, pode ser ela ativa ou passiva. No que se refere à condição estätica predominante, no funcionamento dos elementos que constituem a estrutura, pode-se definir estruturas de tração e de fle xo-compressão.

Relativamente aos revestimentos para pressões internas, procura- se estabelecer um vínculo entre os mesmos e a geometria da seção. E comum adotar-se a forma circular, sendo que nas primeiras obras subterrâneas ado tava-se seja a colocação de condutos forçados metälicos no interior dos tú neis, que funcionassem independentemente destes, ou a abertura de seções tipo ferradura com super dimensionamento das paredes.

No que se refere às pressões sobre o revestimento, hä que se con siderar as pressōes verticais e laterais. No primeiro caso verifica-se que elas são menores que o peso do recobrimento, jä que uma certa porçäo do mesmo é absorvida pelas resistências cisalhantes dos materiais em torno do tünel. Para que essas resistências possam ser mobilizadas, pequenos des locamentos são necessärios, e para is to o revestimento deve ser suficienté mente flexivel; mas não deve sê-lo em excesso pois neste caso, a integrida de da rocha ê destruĩda e as resistênclas ao cisalhamento são inüteis e o revestimento serã totalmente carregado com a carga do recobrimento.

Para a estimativa das cargas verticais que atuam sobre o revesti mento hä värias teorias. Uma delas, de Terzaghi ê representada em termos präticos pela Tabela nümero 61, apresentada por Carvalho (1971), que torna possivel o cálculo da carga de rocha $\mathrm{Hp}$ em metros, sobre o suporte do teto 
de um tünel com largura e altura de $B$ e $H_{t}$ metros, respectivamente, perfurado a uma profundidade superior a $1,5\left(\mathrm{~B}+\mathrm{H}_{\mathrm{z}}\right)$. Pode-se atribuir aos are nitos Caiuã as "condições da rocha" de nümeros 2 a 5 (Fotos de nümeros 2, $3,4,5$ e 6) e a partir daí, obter-se a carga $H_{t}$ desde que conhecidos $B$ e $H_{t}$. O teto de um tủnel ou de uma galeria escavados através de uma rocha po de ser auto suportante por um certo tempo. Chamamse a isto "efeito de ar$\mathrm{col}^{\prime \prime}$ ou "capacidade de auto suporte", o qual, em outras palavras, ë a capacldade da rocha sltuada acima do teto, de transferir a maior parte do peso total da sobrecarga para a região localizada em ambos os lados do tünel.

0 efeito citado depende fundamentalmente:

a) Da grandeza das tensöes de cisalhamento dentro da massa de rochas não escoradas e do vão entre essas;

b) Da dureza de rocha e das dificuldades que a mesma oferece à escavação. Em geral, quanto mais dura a rocha, maior a sua capacidade de auto suporte. Porêm, hä excessões, como algumas rochas quartzíticas, que embora duras de escavar possuem pequena capacidade de auto-suporte.

Uma avaliação da capacidade de arco pode ser feita baseada na es trutura geolögica e na geometria e natureza das descontinuidades da rocha. Assim ë que, em rochas igneas favorecem o seu desenvolvimento, enquanto que rochas muito fissuradas não. Rochas com direção paralela ao eixo do tü nel e de estratiflcação horizontal ou quase e aquelas de direção perpendicular ao eixo do tünel e com forte mergulho favorecem o efeito de arco. A forma e tamanho dos blocos limitados pelas diaclases e juntas, o espaçamen to e o tipo de preenchimento das mesmas tambëm influencia no aparecimento e grandeza do efeito de arco.

Quanto às pressões laterais em geral elas são pequenas no caso de rochas intactas ou duras e mesmo aquelas fraturadas sendo apenas importante para os materiais de comportamento plästico (squeezing ou swelling) e aqueles não coesivos.

As estruturas provisörias de tração notabilizam-se geralmente pe lo seu baixo custo unitärio, ou seja, para um determinado valor do esforço ütil de escoramento, exigem menor consumo de material que as estruturas de flexo-compressão. Um exemplo típico desse tipo de estrutura ê o chumbamento de maciços rochosos, sendo o sistema resistente composto de perfis de aço e de partes integras do maciço rochoso. São as estruturas provisörias de compressão de dois tipos, bäsicamente: os pörticos de apoio, ou seja,as chamadas cambotas associadas ou não a vigas transversais, e os revestimen- 
Tabela $61 ;$

Carga de rocha $H_{p}$ em metros de rocha sobre o suporte do teto do tünel, com largura $B$ metros, altura $H_{t}$ metros e uma profundidade superior a $1,5\left(\mathrm{~B}+\mathrm{H}_{\mathrm{t}}\right)$

\begin{tabular}{|c|c|c|}
\hline Condições da rocha & $\mathrm{Hp}$ & Observações \\
\hline 1. Dura e sã & Zero & $\begin{array}{l}\text { Escoramento leve no caso de ocor- } \\
\text { rer rachaduras ou desprendimento } \\
\text { de lascas }\end{array}$ \\
\hline $\begin{array}{l}\text { 2. Dura, estratificada } \\
\text { ou xistosa }\end{array}$ & 0 a $0,5 B$ & $\begin{array}{l}\text { Escoramento leve somente na aböba } \\
\text { da }\end{array}$ \\
\hline $\begin{array}{l}\text { 3. Maciça com juntas } \\
\text { moderadas }\end{array}$ & 0 a $0,25 B$ & $\begin{array}{l}\text { A carga pode mudar bruscamente de } \\
\text { um ponto para outro }\end{array}$ \\
\hline 4. Blocos moderados e & $0,35\left(\mathrm{~B}+\mathrm{H}_{\mathrm{t}}\right)$ & $\begin{array}{l}\text { Sem pressão lateral, não necessita } \\
\text { escoramento lateral }\end{array}$ \\
\hline $\begin{array}{l}\text { 5. Muitos blocos e fen } \\
\text { das }\end{array}$ & $\begin{array}{l}0,35\left(\mathrm{~B}+\mathrm{H}_{\mathrm{t}}\right) \\
1,10^{\mathrm{a}}\left(\mathrm{B}+\mathrm{H}_{\mathrm{t}}\right)\end{array}$ & $\begin{array}{l}\text { Pouca ou nenhuma pressão lateral; } \\
\text { usar escoramento lateral }\end{array}$ \\
\hline $\begin{array}{l}\text { 6. Completamente esma- } \\
\text { gada porém quimica- } \\
\text { mente intacta }\end{array}$ & $1,10\left(B+H_{t}\right)$ & $\begin{array}{l}\text { Considerävel pressão lateral. Mui - } \\
\text { tas vezes ẽ necessärio usar escora } \\
\text { mento contínuo para as paredes (con } \\
\text { cretagem) }\end{array}$ \\
\hline $\begin{array}{l}\text { 7. Rocha sob pressão } \\
\text { em prof. moderada }\end{array}$ & $\begin{array}{l}1,10\left(\mathrm{~B}+\mathrm{H}_{\mathrm{t}}\right) \\
2,10^{\mathrm{a}}\left(\mathrm{B}+\mathrm{H}_{\mathrm{t}}\right)\end{array}$ & $\begin{array}{l}\text { Grande pressão lateral. Necessärio } \\
\text { o uso de estroncas nos pës das cam } \\
\text { botas }\end{array}$ \\
\hline $\begin{array}{l}\text { 8. Rocha sob pressão à } \\
\text { grande prof. (decom } \\
\text { posta) }\end{array}$ & $\begin{array}{l}2,10\left(\mathrm{~B}+\mathrm{H}_{\mathrm{t}}\right) \\
4,50^{\mathrm{a}}\left(\mathrm{B}+\mathrm{H}_{\mathrm{t}}\right)\end{array}$ & $\begin{array}{l}\text { Recomenda-se para este caso, o uso } \\
\text { de cambotas circulares }\end{array}$ \\
\hline $\begin{array}{l}\text { 9. Rocha expansiva (de } \\
\text { composta) }\end{array}$ & $\begin{array}{l}\text { acima de } 75 \mathrm{~m} \\
\text { independe de } \\
\left(B+H_{t}\right)\end{array}$ & $\begin{array}{l}\text { São necessärias cambotas circula- } \\
\text { res. Em caso extremo usar escora- } \\
\text { mento mais adequado }\end{array}$ \\
\hline
\end{tabular}


tos de casca delgada, executados em concreto, argamassa projetada (gunite) ou concreto projetado (Shotcrete) associado a malhas ou outros elementos resistentes prë-fabricados.

No que se refere às estruturas definitivas, ë possivel se estabe lecer duas classes, segundo ainda Camargo (1971):

- Os revestimentos de contenção, projetados para resistirem aos esforços do maciço rochoso ou, de uma maneira geral, agentes externamente ao revestimento.

- Os revestimentos para pressão interna, cujas solicitações prin cipais atuam internamente ao revestimento.

No primeiro caso, a conceituação coincide com a evolução da própria tëcnica de projetos e de construção de estruturas associadas às obras subterrâneas. A forma mais conservadora de projetos de revestimento prevê a adoção de estruturas dé grande peso e espessura. Seçōes mais leves, com melhor aproveitamento dos materiais empregados, implica em desenvolvimento de anälises de projeto mais refinadas, que sö recentemente passaram a ser adotadas. Em consonância a tais considerações relativas a projeto das formas estruturais, houve a correspondente evolução nas tëcnicas de escava çôes subterrâneas. Assim ê que, em cavidades abertas mais antigamente, ado taram-se seções tipo "ferradura" de "invert" (parte mais baixa do tünel, so leira), revestidas por pesadas paredes de concreto-massa ou alvenaria, nas quais se apoiavam aböbadas suficientemente espessas, Refinamentos construtivos possibilitaram a construção de seçōes "ferradura" com aböbada invertida no fundo, com estruturas de revestimentos articuladas. As soluções flexiveis, finalmente, são mais adaptadas a formas estruturais de eixo con tínuo, como os revestimentos circulares ou de seção em curvas regulares (elipses, ovais).

Quando se pretende tratar aspectos de estabilidade de maciços rochosos en obras subterrâneas adotamse a resistência mecânica como um primeiro critërio de classificação que permita um enfoque global para o problema da sustentação do maciço ao redor da escavação (Martinez, 1980). A noção de resistência mecânica, tal como a definiu Protodiakonov, ajusta- se a tais propôsitos. O coeficiente de resistência mecânica ("f "), segun do o autor acima, é definido como sendo

$f=\operatorname{tg} \phi+\frac{c}{\sigma c}$, no caso de solos 


$$
f=\frac{\sigma k}{100} \text {, no caso de rochas, }
$$

onde:

$$
\begin{aligned}
\phi= & \text { ângulo de atrịto interno efetivo } \\
c= & \text { coesăo do solo } \\
\sigma c= & \text { resistência à compressão simples do solo } \\
\sigma k= & \text { resistência ã compressão simples da rocha, no testemunho } \\
& \text { de sondagem. }
\end{aligned}
$$

O fator de resistêncla foi tabelado por Protodiakonov e coligido por Szēchy (1966), para uma grande variedade de solos e rochas, conforme se vê na tabela 62. Em verdade, para o caso de rochas sölidas (categorias I a V, da tabela 62), uma regra adequada para a determinação do fator "f" è a divisão da resistência cübica da rocha matriz por 100 (Camargo, 1971).

Nesse particular, ë possivel, ao calcular-se os valores limites do coeficiente de resistência para os Arenitos Caiuä, a partir dos dados das tabelas nümeros 55 e 56. Adotar-se a classificação da tabela nümero 61 . Assim ë que, considerando-se os valores de 52 e $55^{\circ}$ para o ângulo de atrito interno $\phi$, de 3,6 e $14,6 \mathrm{~kg} / \mathrm{cm}^{2}$ (minimo e mäximo) para a coesão c e 54 e $337 \mathrm{~kg} / \mathrm{cm}^{2}$ (minimo e mäximo) para a resistência à compressão simples, che ga-se a valores de $f$ iguais a 1,34 (usando-se a förmula $f=\operatorname{tg} \sigma+\frac{c}{\propto c}$ ) $\bar{e}$ 3,37 (usando-se a förmula $f=\frac{\sigma k}{100}$. Esses nümeros permitem codificar os arenitos estudados nas categorias $V \in V I$, ou seja, rochas de resistência mëdia a pouco resistentes. Desde que, conforme a Tabela nümero 55 , os valo res de $\sigma_{c}$ mais comuns são inferiores a $150 \mathrm{~kg} / \mathrm{cm}^{2}$, ë lícito que a maior parte das rochas em questão, seja considerada, para os propósitos em questão, como pertencente à categoria V!.

A partir destes raciocínios, pode-se propor, de acordo com Marti nez (1980), determinados tipos de revestimentos, para rochas daquelas cate gorias, onde sejam escavadas galerias de seção inferior a $10 \mathrm{~m}$, pelos métó dos tradicionais de Engenharia de tüneis e com cobertura, acima da aböbada da cavidade, igual ao diâmetro mëdio da escavação, pelo menos por 1000 me tros de extensão. Esses revestimentos seriam:

Maciços da categoria V: 
- Concreto projetado $(10$ a $20 \mathrm{~cm})$, com ou sem tela, associado ou não a cambotas metälicas.

- Tirantes em malha de 0,50 a $1,20 \mathrm{~m}$, na medida em que a coesão do material ê suficiente para permitir a sua colocação, ou seja com tensões determinadas atravēs de testes, associados a tela e gumita ou concreto projetado, dispostos (os tirantes) o mais pröximo possivel uns dos outros.

- Cambotas metälicas em geral com chapas de blindagem nas calotas.

Ao se adotar as ponderações expressas nas tabelas nümeros 61 e 62, e outras considerações emanadas no desenvolvimento do texto específico de obras subterrâneas, poder-se-ä chegar a uma previsão aproximada dos Are nitos Caiua quanto a tais utilizações:

1) São materiais cujo estado de tensões naturais (tensões virgens) não deverä ser elevado, dadas as sua características genēticas (rochas formadas à pouca profundidade sob condições de pressões e temperaturas quase ambientes), não sendo de se esperar, portanto, fenômenos de descompressão (rock burst) durante as escavaçōes.

2) Para tüneis, com finalidades hidräulicas a questão de sua ero dibilidade face á ação da água em movimento deve ser considerada. Naturalmente os tipos mais susceptíveis são os com cimento limonítico friáveis, melhorando a atuação dos tipos com cimento limonítico e carbonätico e com limonitização superposta a partir de processos de limonitização.

3) Dadas as suas características não acreditamos que possa ser dispensado revestimento temporärio, particularmente em äreas de emboques.

A escolha da sustentação serä tambëm influenciada pelas condições do lençol freático e pelas velocidades de percolação da ägua, por oca sião das escavações.

Maciços da categoria VI

- Concreto projetado $(7$ a $20 \mathrm{~cm})$ sobre tela sustentada por cambo tas metälicas.

- Concreto projetado associado a um sistema de chumbadores. No entanto sugere-se que sejam preferidos os chumbadores de ancoragem continua (com resina) aos de ancoragem pontual (coquilhas). 
4) As atitudes de suas estratificaçôes e suas caracteristicas me cânicas razoảveis permitem supor que possam se deservolver e serem mobilizados efeitos de arco. Todavia, o padrão geomëtrico de seu fraturamento com posta necessariamente uma avaliação e estudo analítico, sendo que ainda se considera que aquele efeito possa ser mobilizado em bancos de arenitos mais maciços e levando-se em conta a profundidade da escavação.

E lifito ponderar que as rochas aqui consideradas sejam incluidas, nas categorias 4 e 5 da Tabela nủmero 61. Nota-se então que as cargas de rocha, sobre o suporte do teto, a partir numa escavação com dimensões, por exemplo, de 3 metros (B) por 4 metros $(\mathrm{Ht})$, a uma profundidade superior a $1,5(B+H t)$, poderão variar de 0,17 a $0,77 \mathrm{~kg} / \mathrm{cm}^{2}$, cabendo as observações constantes na tabela, relativamente às pressões e escoramentos laterais.

5) "Overbreak" (sobrefuração alêm da linha de projeto) deverä ser muito intensa caso os mëtodos de desmonte não estejam adequadamente es pecificados e sob controle rigoroso de fiscalização.

Deve-se enfatizar, no entanto, que no caso de rochas estratifica das, como ë o caso de grande parte dos Arenitos Caiuá, o padrão e a atitude dessa estratificação, associada ao diaclasamento existente, tenderão a modificar a distribuição e os valores das pressões sobre escoramentos. Tam bém a ação dos processos de limonitização em profundidade deve ser avaliada, pois deverão os mesmos acrescer significativa parcela de resistência à rocha, alterando os padrões das pressões prevalescentes. 
Tabela 62

Fator de resistência mecânica para solos e rochas

\begin{tabular}{|c|c|c|c|}
\hline Categorla & Descrição & Exemplos & $\begin{array}{c}f \\
\text { (unidade) }\end{array}$ \\
\hline 1 & $\begin{array}{l}\text { Rocha de resistência } \\
\text { elevada }\end{array}$ & $\begin{array}{l}\text { Quartzitos e basaltos de al } \\
\text { ta resistência }\end{array}$ & 20 \\
\hline 11 & $\begin{array}{l}\text { Rochas multo resisten } \\
\text { tes }\end{array}$ & $\begin{array}{l}\text { Granitos muito resistentes, } \\
\text { pörfiros, arenitos e calcä- } \\
\text { reos de resisténcia bastan- } \\
\text { te elevada }\end{array}$ & 13 a 19 \\
\hline 111 & $\begin{array}{l}\text { Rochas de boa resis } \\
\text { tência }\end{array}$ & $\begin{array}{l}\text { Granitos, arenitos e calcá- } \\
\text { reos de resistência boa ou } \\
\text { ligeiramente desgastados, } \\
\text { märmores, dolomitos, conglo } \\
\text { merados compactos. }\end{array}$ & 7 a 13 \\
\hline IV & $\begin{array}{l}\text { Rochas bastante resis } \\
\text { tentes }\end{array}$ & $\begin{array}{l}\text { Arenitos comuns, } x i s t o s \text { si- } \\
\text { licosos ou arenitos estrat } \\
\text { ficados. }\end{array}$ & 5 a 7 \\
\hline v & $\begin{array}{l}\text { Rochas de resistência } \\
\text { mëdia }\end{array}$ & $\begin{array}{l}\text { Xistos argilosos, arenitos } \\
\text { e cälcareos de resistëncia } \\
\text { média, margas compactas, con } \\
\text { glomerados pouco consisten- } \\
\text { tes. }\end{array}$ & 3 a 5 \\
\hline VI & $\begin{array}{l}\text { Rochas pouco resisten } \\
\text { tes }\end{array}$ & $\begin{array}{l}\text { Xistos ou calcäreos pouco } \\
\text { consistentes ou bastante } \\
\text { fraturados, margas comuns, } \\
\text { gipsos, arenitos muito fra- } \\
\text { turados. Concreçōes e solos } \\
\text { arenosos comprimidos. Argi- } \\
\text { las duras. }\end{array}$ & 1,3 a 3 \\
\hline$V ! I$ & $\begin{array}{l}\text { Rochas sedimentares } \\
\text { pouco litificadas. } \\
\text { Solos muito consolida } \\
\text { dos }\end{array}$ & $\begin{array}{l}\text { Argilas, aluviões coerentes, } \\
\text { areias argilosas consolida- } \\
\text { das. Areias e cascalhos (sai } \\
\text { bros) compactos. }\end{array}$ & 0,9 a 1,3 \\
\hline$V\|\|$ & $\begin{array}{l}\text { Solos medianamente } \\
\text { consolidados }\end{array}$ & $\begin{array}{l}\text { Turfas, areias argilosas. } \\
\text { Areias umidas medianamente } \\
\text { consolidadas. }\end{array}$ & 0,7 a 0,9 \\
\hline IX & $\begin{array}{l}\text { Solos pouco consolida } \\
\text { dos }\end{array}$ & $\begin{array}{l}\text { Aterros plästicos pouco con } \\
\text { solidados. Areias ou casca } \\
\text { lhos parcialmente saturados }\end{array}$ & 0,5 a 0,7 \\
\hline$x$ & Terrenos escorregadios & $\begin{array}{l}\text { Lodos e outros solos plästi } \\
\text { cos saturados. }\end{array}$ & 0,5 \\
\hline
\end{tabular}




\section{Taludes em Arenitos Caiuả}

Com o intuito de estabelecer premissas referentes ao comportamen to previsivel dos Arenitos Caiua em taludes, recorrer-se-ä, inicialmente, a algumas colocações feitas por Cruz (1969), inerentes ao assunto.

0 autor acima enfatiza alguns pontos como a obrigatőria distinção, em colapso de taludes, entre o que chama ruptura geral, da ruptura lo cal. No primeiro caso, ë possivel o movimento de rocha ou massa de terra na altura plena do talude, e no segundo caso, a ruptura restringe-se a al guns blocos que se desprendem do mesmo. Esclarece ainda da necessidade em se enquadrar a rocha dentro de um modelo estrutural, como se faz, por exem plo, para apresentação de estruturas de argilas ou areias, em Mecánica dos Solos, ou ainda adotando-se para a rocha uma classificação típica, consagrada,

0 mesmo autor propõe ainda como necessârio, o estudo da água nos vazios da rocha, ou seja, o estudo dos caminhos preferenciais de percolação pelo maciço. Na sequência por ele proposta, deve-se proceder ã anälise da geometria do problema, quer dizer, a posição correta dos planos de es tratificação, acamamento, bem como a determinação do talude de corte desejado.

Este procedimento permite definir o limite possível do escorrega mento, que pode se estender, dependendo das relações entre aqueles, a dis tâncias relativamente grandes.

Na questão das propriedades mecânicas considera-se, segundo ainda Cruz (1969), particularmente sua resistência ao cisalhamento. Para tan to, procura-se, sobretudo fixar-se:

a) Uma equação-tipo de resistência, a partir do modelo estrutural prë-definido, ou uma classificação de tabela;

b) A estrutura da resistência ao cisalhamento dos materiais, nos planos de fissuras, ou contatos;

c) A estimativa de uma resistência ao cisalhamento mëdio, em pla nos potenciais de ruptura.

Tals ftens são satisfeitos, pela realização de ensaios "in situ" ou recorrendo-se a ensaios executados com materiais semelhantes. No que se refere a arenitos estudados (Arenitos Bauru e Botucatu), Cruz (1969) escla rece que a tendência são equaçôes de resistêncla de ângulos de atrito (申) 
elevados, porêm com coesão (c) quase nula. Finalmente, o estudo da estabilidade, que se resume num problema estátịco, consiste na determinação das forças atuantes e resistentes, no processo de ruptura, com a fixaçâo de um coeficiente de segurança major do que 1.

Ao examinar a questão dos agentes e causas de movimentos de mas sas, Guidicini e Nieble (1976) ponderam a importância dos processos de ín temperismo no enfraquecimento gradual dos maciços rochosos. Is to se proces sa pela remoção dos elementos solüveis constituintes dos pröprios minerais e pela dissolução dos constituintes cimentantes em solos ou rochas sedimen tares, graças ao desenvolvimento de uma rede de microfraturas em um meio rochoso que não as possuia. Esclarecem que, com o aumento do índice de al teração, observa-se uma clara diminuiçâo da coesão e ângulo de atrito, pá ra rochas graniticas ensaladas no Laboratörio Nacional de Engenharia Civil, em Lisboa. Aqueles autores ainda ponderam que os processos de alteração ocorrendo em solos, poderão resultar, às vezes num seu maior adensamento,ou numa cimentação secundäria, aumentando suas características de resistência, acontecendo o oposto com as rochas. Guidicini e Nieble (1976), ao refletir sobre os mêtodos para cälculos de estabilidade de taludes, examinam a análise da estabilidade de equilíbrio limite. Ponderam que, para comparar a estabilidade de taludes en condições diferentes de equilíbrio-limite, defi ne-se o fator de segurança FS como sendo a relação entre a resultante das forças solicitantes e resistentes ao escorregamento. A condição de equilíbrio-limite corresponderia um coeficiente de segurança unitärio. Pode-se ver na figura nủmero 68, que um bloco de rocha solicitado pelo seu peso pröprio $P$ é sujeito a uma parcela $P$, sen $i$ do mesmo que tende a causar 0 escorregamento, enquanto que o esforço normal atuante na base do bloco (sú perficie de escorregamento) vale $\mathrm{P}, \cos \mathrm{i}$.

0 esforço resistente vale $R=A$, sendo

$Z=$ resistência ao cisalhamento do contato bloco/plano inclinado, e cuja expressão è

$\xi \quad=c+\sigma \operatorname{tg} \phi$, onde

$c=$ coesão

$\phi=$ ângulo de atrito no contato bloco/plano inclinado

$A=$ Area da base do bloco

Tem-se então 


$$
\begin{aligned}
& \zeta=\frac{P \cdot \cos i \cdot \operatorname{tg} \phi}{A} \\
& \text { Como } R=\zeta A, \quad \sigma=P \cdot \cos i \cdot \operatorname{tg} \phi \\
& \text { O Fator de segurança serä } \\
& F S=\frac{P \cdot \cos i \cdot \operatorname{tg} \phi}{P \cdot \operatorname{sen} i}=\frac{\operatorname{tg} \phi}{\operatorname{tg} i}
\end{aligned}
$$

$\mathrm{Na}$ condição de equilibrio-limite $(F S=1)$ tem-se que

$$
i=\phi
$$

Os autores citados reconhecem ser a anâlise acima muito simplista, e välida apenas para fins llustrativos. Nos casos reais, é necessário conhecer-se realmente as limitações da anälise com base na adoção dos fato res de segurança. Advertem que os especialistas atuais aceitam o fator de segurança como um indice relativo, utilizado para analisar a sensibilidade do projeto a mudanças em parâmetros significativos.

Tratando aspectos da resistência ao cisalhamento de rochas, Mel lo e Teixeira (1969) ponderam que, um maciço de rocha pode ser admitido como um sistema de blocos justapostos nas três direções do espaço, e carac terizados pelos espaçamentos $d_{1}$ e $d_{2}$ entre as familias de diaclases, no plano; pelo imbricamento ou defasagem $i$ entre os blocos e pelo ângulo $\alpha$ formado pelas direções das duas familias de diaclases. Casos particulares são representados por um imbricamento $i=0$ (zero), ou seja, não hä defasa gem de blocos, e o ângulo $\alpha=90^{\circ}$, quer dizer, os blocos são delimitados por dois sistemas de diaclases perpendiculares. No caso de uma superfície potencial de ruptura segundo uma diaclase descontínua, aquela terá como es forços resistentes tanto a coesão $c_{0}$ da rocha, ao longo da ärea $A_{o}$ da seção atravẽs do bloco, como a resistência por atrito ao longo da superfície da diaclase. A coesão efetiva será

$$
c_{e}=c_{o} \frac{A_{0}}{A}
$$

sendo A a área total de superfície de ruptura. Se o ë a tensão normal num ponto do maciço e $\mu$ a pressão hidrostätica de ãgua nesse ponto, a resis tência ao cisalhamento do maciço serã

$$
\zeta=c_{e}+(\sigma-\mu) \operatorname{tg} \phi
$$




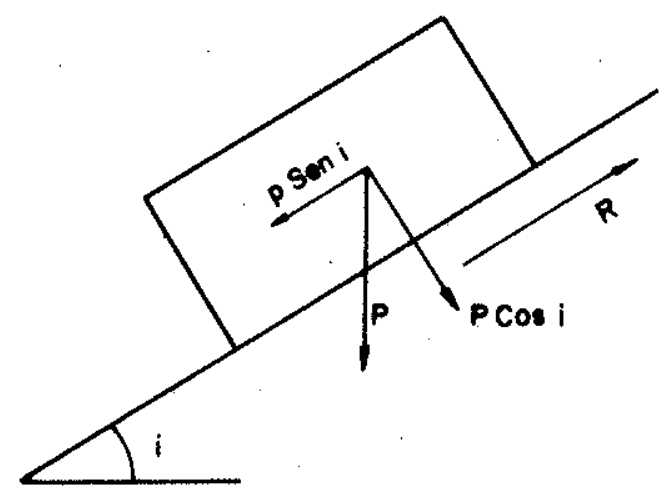

FIG. 68 - RELAÇĀo de forGAS NA ANÁLISE de EQUILÍBRIO - LIMITE ( SEg. GUIDICINI E NIEBLE - 1976)

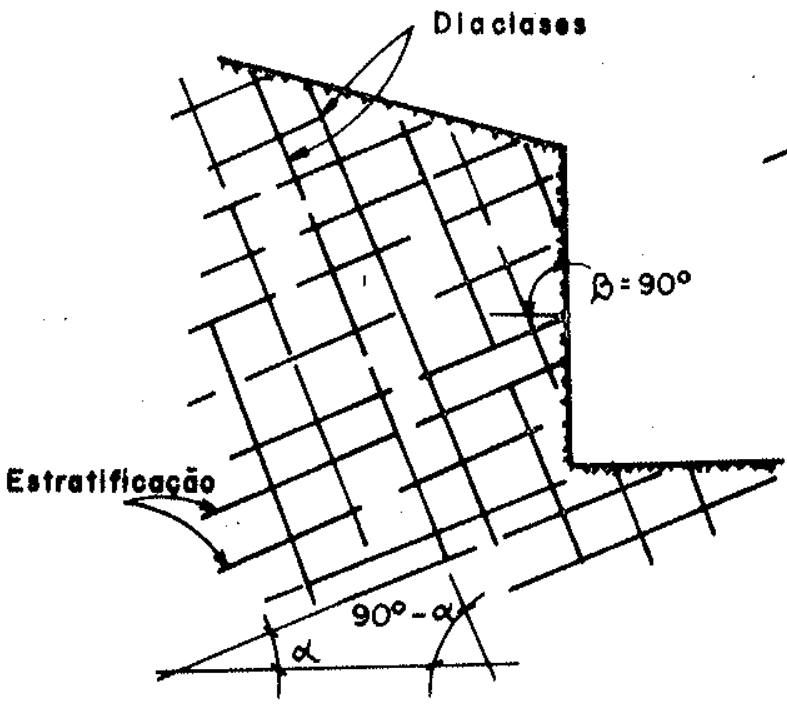

(a)

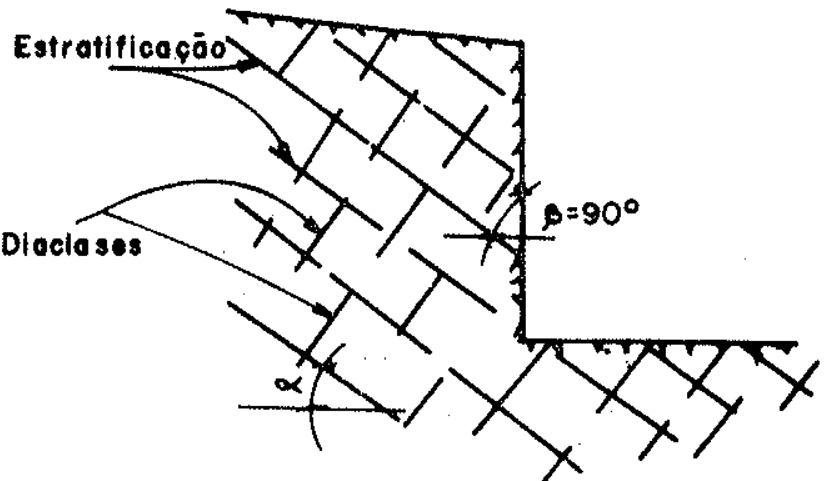

(c)
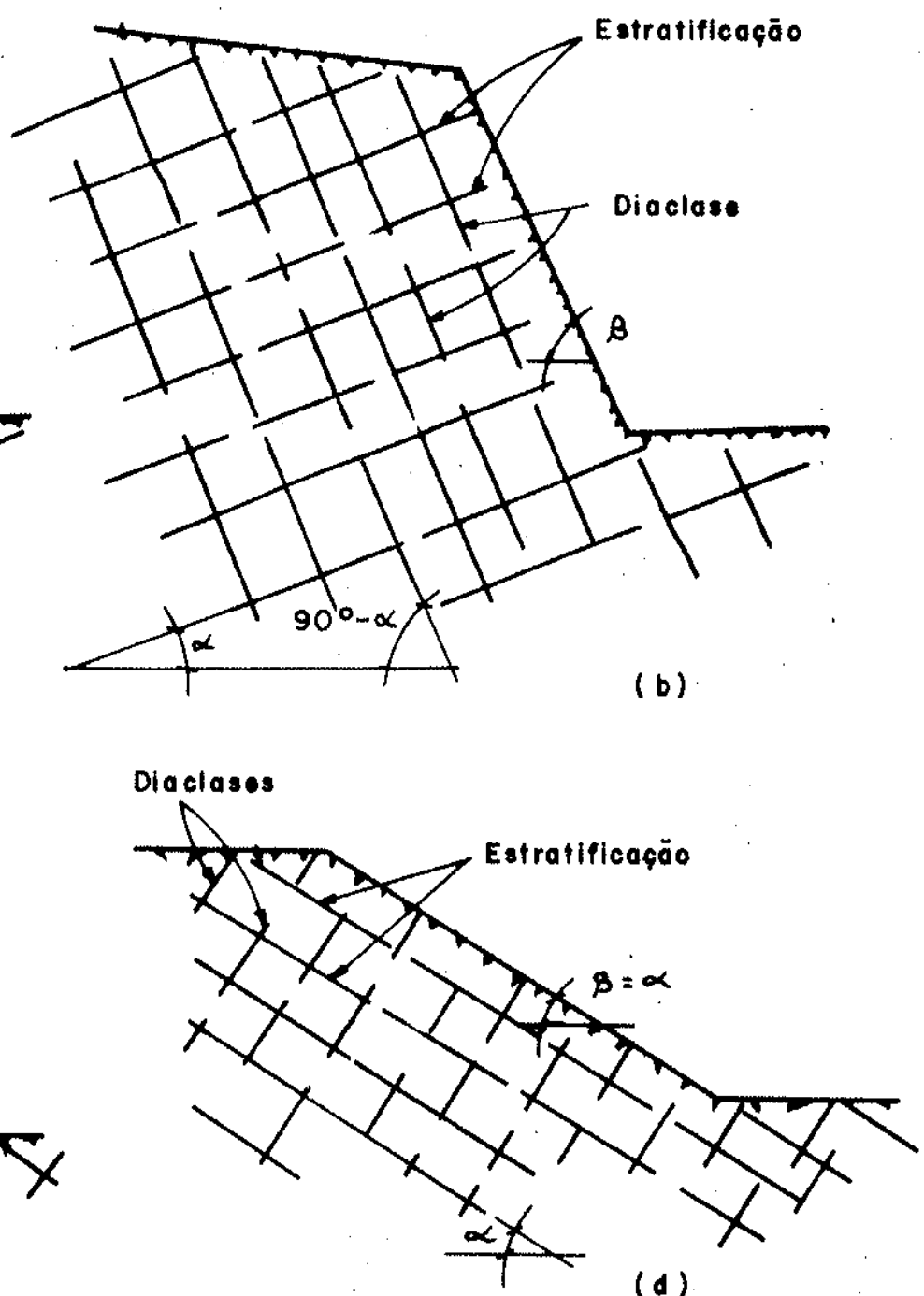

(d)

FIG. 69 - CONDIÇÕES PARA A ESTABILIDADE DE TALUdES EM ROCHAS ESTRATIFICAS E DIACLASADAS (SEG. MELLO E TEIXEIRA - 1969 ) 
Os autores citados examinam värịos casos típicos onde os padrões geométricos do dịclasamento relatịamente aos taludes, são considerados à luz de suas varịações, Os padróes geomëtricos referidos são representa dos por:
a) Imbricamento, i
b) Angulo dos estratos com a horizontàl, a
c) Angulo de talude critico estâvel $\beta$;
d) Angulo de atrito ao longo dos planos de fratura, $\phi_{1}$.

A estabilidade do talude em rocha dependerä, essencialmente, da orientação dos planos de estratificação em relação à superfície do talude, ilustrado atravës de modelos como os que se seguem (Figura nümero 69:) 0 primeiro deles sugere planos de estratificação com o mergulho para den tro do maciço e imbricamento nulo. Nesse caso, se o ângulo $90-\alpha<\phi_{1}$, os blocos de rocha não deslizam ao longo do plano das fraturas, resultando num talude crítico estävel vertical, $\beta=90^{\circ}$ (Figura nümero 69,a). Por outro lado, se $90-\alpha>\phi_{1}$, haverä deslizamentos, ao longo dos planos de fra turas transversais aos planos de estratificação, tendo um ângulo de talude estävel $\beta=90-\alpha$ (Figura nümero 69 , b).

No segundo modelo, os planos de estratificação têm mergulho pa ra o talude, sendo $\alpha_{2}$ o ângulo de atrito entre as superfícies dos planos de estratificação. Nesse caso, se $\alpha>\phi_{2}$, não ocorre o deslizamento ao longo da estratificação, e resultarä um ângulo de talude crítico vertical $\beta=90^{\circ}$ (Figura número $69, c$ ). Por outro lado, se $\alpha>\phi_{2}$, ocorre o desliza mento dos blocos ao longo da estratificação, sendo o ângulo de talude crítico estâvel $\beta=\alpha$ (Figura nümero $69, \mathrm{~d}$ ).

Do exposto, e a partir das observações na escavação no local 11 (Fotos nümeros 2, 3, 4, 5 e 6) e outros taludes naturais, é lícito esperar que taludes escavados em Arenitos Caiuä, tenham o seguinte comportamento, de maneira geral:

1) O tipo de ruptura que se estabelecerä ë aquele que cruz(1969) chama de ruptura local, e que jä fol referido no texto. Isto se explica pelo fato de que os colapsos provāvels serão governados pelos planos de acamamento, estratificação e diaclasamento. Evidentemente, a conjunção des ses fatores, forçosamente vinculada à sua configuração espacial, resultarā em condiçōes propicias ao estabelecimento da ruptura. Naturalmente, as si tuações mais propícias serão: 
a) As direçốes das estruturas e planos de diaclasamento cịtados são paralelas ou quase, ao talude, em associação com outros sistemas de disjunção cujas direçôes sejam quase normais às primeiras;

b) Os mergulhos dos referidos planos do diaclasamento e estruturas fazem ângulos acentuados com a horizontal e são truncados pela escavação.

As situações descritas tendem a originar cunhas de material potencialmente instävel. Evidentemente que esta potencial instabilidade torna-se real quando as resistências ao cisalhamento nos planos que delimitam as cunhas seja menor que a componente de força peso que tenderã a movimentar o bloco.

As condições mais proximas às dos itens citados, por exemplo na escavação mostrada nas fotos nümeros $2,3,4,5$ e 6 , são aquelas representadas pela combinação das diaclases $N 70^{\circ} \mathrm{W}$ e $N 11^{\circ} \mathrm{W}$ de mergulhos $89^{\circ} \mathrm{NE}$ e $87^{\circ} \mathrm{NE}$, com a $\mathrm{N} 43^{\circ} \mathrm{E}$ e $\mathrm{N} 59^{\circ} \mathrm{E}$, de mergulhos vertical e $77^{\circ} \mathrm{SE}$ (tabela nümero 1). A incidência das duas primeiras ê muito maior, relativamente às outras, o que sugere que tais condições de instabllidade não são muito fäceis de ocorrer, o que aliäs se comprovou naquele local,

2) Poder-se-ä contar, nas considerações relativas ã estabilidade, com uma parcela de coesão, nos planos das estruturas e dos diaclasamentos, devida ã deposição de limonita nos mesmos.

3) Hipöteses relativas ã ruptura do maciço em si são menos viäveis, dado que a resistência ao cisalhamento mobilizada serä bastante elevada (ângulo de atrito interno iguais a 52 e $55^{\circ}$; tabela nümero 57 ), muito embora os valores da coesão sejam anormalmente altos $(3,6 ; 6,1 ; 11,1$ e $14,6 \mathrm{~kg} / \mathrm{cm}^{2}$, tabela nủmero 57 ) para o material em questão, ainda que se admita que tais valores tenham sido obtidos a partir de ensaios onde as tensões normals tenham sido aplicadas normalmente à estratificação.

4) Pode ser esperada uma maior desagregação do material, sobretu do em superficie, onde normalmente a tendência é a presença de maior incidência de fendilhamento, e de material jä desagregado. Este fato reforça as idëias de Guidicini e Nleble (1976) de enfraquecimento gradual dos maci ços rochosos pelo intemperismo, porêm não se pode esquecer que, a limoniti zação secundåria atribui ã rocha melhorias que devem ser consideradas, e influentes na sua resistência.

5) Os efeitos da estratificação cruzada certamente irão se sobre por aos causados pelos diaclasamentos, particularmente nos aspectos de ré 
sistência da rocha. Desta maneira hâ que se ponderar as parcelas relativas a tais estratificações na estabilidade de taludes.

6) A ägua poderä influenciar a estabilidade desde que percole 11 vremente pelos planos de estratificação, diminuindo os valores da coesão c e da tensăo normal na equação da resistência $Z_{=}=c+(\sigma-\mu) \operatorname{tg} \phi$ (Terzaghi, 1952). Vê-se na foto nümero 4, , um plano preferencial de perco lação onde a influência da ägua poderä se fazer sentir.

7) A disposição espacial das estratificações cruzadas na escavação das fotos nümeros $2,3,4,5$ e 6 ê algo variável, de forma a não facilitar a plena adoção de modelos como os de Mello e Teixeira (1969) jä comentados. Pode-se admitir, no entanto, que não hä imbricamento e que poderão ser satisfeitas as condições de estabilidade $90-\alpha<\phi_{1}$ (1) e $\alpha<\phi_{2}$ (2). Assim è que, admitindo-se valores de $30^{\circ}$ a $35^{\circ}$ para $\phi_{1}$, a partir de ensaios apös ruptura (sliding tests) com Arenitos Bauru (Celeri e Paes de Barros, 1969). Ter-se-ã satisfeita, para ângulo $\alpha$ de, no mäximo $40^{\circ}$, medi do no local da citada escavação, e alguma coesão, a condição de equilíbrio (1). A condição (2) tambëm ë satisfeita com o valor $\phi_{2}=40^{\circ}$.

8) Os taludes mëdios (ângulo $\beta$ ) recomendados para cortes típicos no Canal de ligação Rio Tietê-Rio São José dos Dourados (Celeri e Paes de Barros), em Arenitos Bauru, foram de $80^{\circ}, 70^{\circ}$ e $60^{\circ}$, para alturas de corte iguais a, respectivamente 10,20 e $30 \mathrm{~m}$, sendo previstas bermas e patamares de 5 metros de largura para cada uma dessas alternativas. Observando-se alguma similaridade entre os dois Arenitos, Caiuä e Bauru considera dos, do ponto de vista de resistência, poder-se-áadmitir as mesmas inclinações para o Caiuã, como ponto de partida para uma determinação mais precisa, vindo-se então a manipular dados que ainda agora não se dispõem.

\section{Conclusões e recomendações finais}

Com este trabalho, objetivou-se, uma primeira ingressão ao estudo e compreensão das propriedades geotêcnicas dos Arenitos Caiuä. Muase que naturalmente uma proposta desse tipo conduz a considerações outras que levam a conjecturas sobre o seu comportamento como material aplicado em obras civís, como decorrência da quase impossibilidade de separação entre a anälise dos dados e a aplicação, em termos präticos.

Quer-se crer que os Arenitos Caiuä representam uma fonte potencial de materlais de construção de boa rentabilidade técnica e econômica, 
pelas sua grande ärea de ocorrência e particularmente em regiōes onde : o progresso estä por se instalar atravës da provävel construção de grandes obras hidrelêtricas.

Evidentemente pelo que foi possivel concluir neste trabalho, não é uma rocha que possa ser enquadrada na categoria dos materiais absoluta mente nobres como materiais de construção, Isto pelo fato de que tem sido muito frequente entre nös a sistemätica de empregarmos para aquelas finali dades, rochas igneas e sempre que possivel, sãs. Ainda mais, procura-se nor malizar a aplicação dos materiais atravēs de especificações, em grande par te, inadequadas às nossas realidades.

A aplicabilidade dos frenitos Caiuä dependerä evidentemente, da adoção de critērios adequados às suas particularidades físicas, alēm de muito bom sendo, procurando sempre sua aplicação seletiva, e em zonas das obras, onde o seu comportamento não comprometerä a viabilidade tëcnica do projeto; assim em obras de represamento, poderä ser usado como ensecadeiras de caräter temporärio ou em partes internas de enrocamentos subjacente a materiais de qualidades mais aceitäveis.

A propösito deste momentoso problema, de Mello (1972) fez uma abordagem extremamente oportuna da qual se reproduz parte, a seguir: "Um dos problemas que merece a nossa maior atenção è o do aprovei tamento de ma teriais pedregosos menos sãos. Por outro lado, tal aproveitamento tem encontrado uma certa resistência, porque não encontra muito apoio de literatura técnica, não tendo constituído preocupação comum dos países mais desenvolvidos nördicos: por outro lado, o problema compreende inescapavelmen te um programa de investigação a longo prazo, Não se entende, porēm, que por um programa ser de longo prazo, automaticamente se adie o seu inicio; a atitude öbvia seria a conträria, de começar o quanto antes. Acresce que perante problemas de desintegração e decomposição, as observaçöes visuais são sempre desfavoravelmente exageradas por corresponderem sö à superfície exposta; também os ensaios laboratoriais sem a confirmação da experiência "in natura" não chegam a merecer muita fë. Assim, a ünica sugestão que se pode fazer è de se começar imediatamente a empregar os materiais menos sãos, porëm restringindo o seu emprego a situações de menor responsabilida de, de observação fácil e programadamente sistemătica, e de manutenção ou eventual substituição economicamente aceitävel, 0 ponto fundamental ẽ que em materiais desagregäveis e alteräveis a pesquisa de sua qualidade e condição "in situ" tem muito pouco sentido considerando as acentuadas alterações que se produzem no desmonte, no manuseio e na compactação. Exigem-se 
ensaios de campo: mas estes tambểm sô têm sentido quando procedidos nas condições (equipamentos, etc) que realmente a Empreịteira aplicarä na obra; assim, ë imprescindivel que se crlem no projeto condiçōes para colocar materiais suspeịtos em zonas de compactação experịmental aproveitäveis sem maiores riscos para a constituị̧ão do maciço".

Por outro lado, ê certo que os arenitos Caiuá sofrem processos de limonitização que thes conferem um comportamento particular, e parameIhor, relativamente ao original.

Como jä o afirma Farjallat (1972), podem acontecer situações onde as propriedades mecânicas das rochas alteradas sejam melhores do que as respetivas menos alteradas, graças a uma limonitização secundäria que pode reforçar as ligações cristalinas de uma rocha mais alterada mineralogicamente, tornando-a mais resistente que a alterada, fenômeno parecido, mas em outra escala, com a petrificação dos solos. Ainda com relação a este assunto, segundo Gidigagu (1976), a experiência de campo demonstra que as caracteristicas geotëcnicas e o comportamento de campo dos solos laterí ticos são consideravelmente influenciadas pela sua gênese, características morfolögicas, grau de intemperismo e composição química e mineralógica, ca da um desses fatores sendo correlacionävel ao sistema de intemperismo de terminado pelo efeito conjunto dos fatores pedogenéticos (rocha original, clima, vegetação, etc.). Ainda mais, as características geotẻcnicas, o com portamento em obras de engenharia, bem como sua reação a diferentes agentes estabilizantes da maioria dos solos formados em condições tropicais, podem ser previstos por informações disponiveis a respeito do sistema de intemperização, gênese e mineralogia, ao invës das deduções ortodoxas dedu zidas a partir de dados isolados, de natureza empirica; por tal razão, os ensaios devem ser restritos a apenas estudos comprobatörios. Desta maneira, o equacionamento da questão relativa ao conhecimento das propriedades geotêcnicas dos Arenitos Caiuä deve ser necessariamente estruturado em fun ção da evolução pedogenètica dos mesmos com a participação da geoquímica superficial e físico química, tendo os processos climâticos como pano de fundo. Assim, será possivel estabelecer um zoneamento adequado dos maciços areniticos, orientativo para a sua aplicação. 
Aires-Barros, L. Alteração e alterabilidade de rochas ígneas. Laboratörio Nacional de Engenharia Civil. Lisboa, 1971.

Aires-Barros, L. \& Graça, R.C. Test on accelerate abrasion and chemical mo bilization of rocks. Bull, of the Intern. Ass. Eng. Geology, n? 3, Paris, 1971.

Aires-Barros, L. Comparative Study between Rates of Experimental Laboratory Weathering of Rocks and Their Natural Environmental Weathering Decay. Bull. of the Intern. Assoc. of Engineering Geology, ne 18, pp. $168-174,1978$.

Almeida, Fernando F.M. Botucatu, um deserto triássico da Amërica do Sul. D.N.P.M. D.G.M. n? $86,1-21,1954$.

Almeida, Fernando F.M. Fundamentos geolögicos do relevo paulista, Bol. do Instituto Geogräfico e Geolögico, p. 167-274, São Paulo, 1964.

Araujo, Jesus S. E Silva, Ricardo F. da. Consideraçōes sobre uma boçoroca em terreno basáltico. In: Congresso Brasileiro de Geologia, 27, Araca ju, 1973.

Associação Brasileira de Cimento Portland. Solo-cimento: métodos para ensaios de laboratörio, São Paulo, 1956.

Azevedo, A.A., Oliveira, A.M.S. E Soares, L. Injeções de vellação em fundacões basálticas de barragens gravidade, Anais do 2 ? Cong. Bras. de Geol. Eng., vol. 1, São Paulo, 1978.

Ayrapetyan, R.A. Modern Rock Fill Dams, Israel Program for Scientific Translation, Jerusalëm, 1970.

Bagolini, Bernardo. Notte sulla geologia del basalto dell'Al to Bacino del Fiume Paranä, Nel Brasile Meridionale, Rel. Themag Engenharia, São Pau $10,1964$. 
Bagolini, Bernando \& Guidicini, Guido. Barragem de Bariri, aspectos geolögicos da rocha de fundação, Rel. CHERP, São Paulo, 1964.

Barata, F.E. Landslides in the Tropical Region of Region of Rio de Janeiro, 79 Int. Congr. Soil Mec, Found. Eng., Mexico, vol, 2, pp. 507-516, 1969.

Barton, M.E. Soft Sandstones: Geotechnical Properties and Sensitivity to Moisture Changes. Proceedings of the Second International Congress of the International Association of Engineering Geology, vol. I, IV-7.1 a IV-7.6, São Paulo, 1974.

Baynes, F.J. \& Dearman, W.R. The relationship between the microfrabric and the engineering properties of weathered granite. Bull. of the $1 \mathrm{n}$ tern. Assoc. of Eng. Geol., ne 18, pp. 191-197, 1978.

Bell, F.G. The physical and mechanical properties of the Fell Sandstones, Northumberland, England, Engineering geology, vol. 12 n. 1, pp. 1-29, 1978.

Bigarella, J.J. Contribuição à petrologia dos arenitos da Sërie São Bento: Arq. Biol. Tec., $4: 141-214,1949$.

Bjornberg, Alfredo J.S., Gandolfi, Nilson \& Paraguassu, Antenor B. Novas observações sobre a tectônica rígida do leste do Estado de São Paulo, Rev. Eng. Mineração e Metalurgia, v. XII, n 224, p. 137-140, 1965.

Bjornberg, Alfredo J.S. Sismogênese e Neotectônica do Sul do Brasil (Estado de São Paulo). 8\% Seminärio Nacional de Grandes Barragens, São Pau10,1972 .

Bjornberg, Alfredo J.S. \& Meismith, C.J. Problemas geolögicos de fundação de barragens sobre basaltos, An. 10 \% Sem. Bras. de Grandes Barragens, Curitiba, 1975.

Bordeaux, Guij H.R.M. Mëtodos construtivos de barragens de enrocamento. $6 \%$ Seminärio Brasileiro de Grandes Barragens, Rio de Janeiro, 1970.

Bösio, Nivaldo J. \& Landim, Paulo M.B. Formação Caiuả: sedimentologia e estratigrafia, In: Congresso Brasileiro de Geologia, 23, Salvador, 1969. 
Bösio, Nivaldo J. \& Landim, Paulo M. B, Um estudo sedimentolögico sobre a Formação Caiuä. Bol, Paran. Geoc, nos 28-29:145-157, 1971.

British Standard Institution. Especification for Rolled Asphalt (hot process) for roads and others paved areas. B.S, 554, London, 1973.

Brito, S.A.A, de. Feições geológicas no basalto da barragem de Volta Grande. An. 7\% Sem. Bras, de Grandes Barragens, Rio de Janeiro, 1971.

Camargo, Fernando P. de. Geologia Aplicada à barragem de llha Solteira, Sis tema Urubupungä. An. Assoc. Paul. Geol, Aplic., vol. IIl, São Paulo. 1969.

Camargo, Wander M. de. Escoramentos e revestimentos definitivos para obras subterrâneas: hipóteses de carga - critërios de cãlculo - Relato sobre o tema. Anais da 3 a Semana Paulista de Geologia Aplicada, vol. 11 , São Paulo, 1971.

Carvalho, Osnyr S. Escoramento provisörio nas escavações subterrâneas. II Semana Paulista de Geologia Aplicada, da Associação Paulista de Geologia Aplicada, São Paulo, 1971.

Cedergreen, H.R. Drainage of Highway and Avifield Pavenents. John Wi ley $\varepsilon$ Sons, New York, 1974.

Celeri, Roberto 0. E Paes de Barros, Fernão. Taludes do canal de ligação Rio Tietê-Rio São Josê dos Dourados. Anais da $1 \stackrel{\text { a }}{\text { Semana Paulista de }}$ Geologia Aplicada, vol. I, Associação Paulista de Geologia Aplicada, São Paulo, agosto 1969.

Cordani, Umberto G. \& Vandoros, P. Basaltic rocks of the Parana Basin. In: International Symposium on the Gondwana Stratigraphy and Paleontology, 19, Mar del Plata, e Proceedings "Problems in Brazilian Gondwana Geolo gy", Curitiba, Instituto de Geologia da Universidade Federal do Paranä, pg $207-231,1967$.

Costa Nunes, A.J. da. Uso da protensão em barragens e estruturas auxiliares. Revista Saneamento, Rio de Janeiro, DNOS, (28): 41-49, Jan. Mar. 1966.

Costa Nunes, A.J. da \& Bogossian, Franciss. Ensaio de cisalhamento de gran des dimensões em enrocamentos de barragens. VI Seminärio Nacional de Grandes Barragens, Rio de Janeiro, 1970. 
Christofoletti, A, Os derrames de basalto da Serra de Santana. Bol, da S, B. G, , n: $12(1 / 2): 65-73,1963$.

Cruz, Paulo T. da, Geologia de Taludes. Anais da $1 \stackrel{\text { a }}{\text { Semana Paulista de }}$ Geologia Aplicada, da Associação Paulista de Geologia Aplicada, vol. 1, São Paulo, 1969.

Cruz, Paulo T. da. Solos residuais compactados de arenitos e basaltos. Ins tituto de Pesquisas Rodoviärias, publicação n? 438, Rio de Janeiro. 1970 ,

Cruz, Paulo T. da. Materiais de Construção: sua utilização racional em aterros de estradas e barragens. Revista Construçäo Pesada, São Paulo (39): 36 , Abril 1974.

Dearman, W.R. Weathering classification in the characterization of rock for engineering purposes in British practice. Bull. of the Intern. Assoc. of Engin. Geol., n? 9, pp. 33-42.

Dearman, W.R. Weathering classification in the characterization of rock: a revision. Bull, of the Intern. Assoc. Of Engin. Geol, n? 13, pp. 123-127.

Deere, D.U. \& Patton, E.D. Slope stability in residual soils. State-of-the -Art Paper, 4: Panam. Cong. Soil Mec. Found. Engin., Porto Rico.

Delgado Rodrigues, J.V. Previsão da alterabilidade de materiais rochosos naturais. Revista Geotecnia, ne 20, Lisboa.

Farjallat, Josë E.S. E Suguio, Kenitiro, Observações sobre a zeolitização em basalto e arenito em Nioaque, Mato Grosso. Bol. Soc. Bras. Geol., vol. 15, no 3, São Paulo, 1966.

Farjallat, Josẽ E.S. Estudos experimentais sobre a degradação de rochas ba sajticas - basaltos da barragem de Capivara, rio Paranapanema. Tese de Doutoramento, Inst. de Geociências, U.S.P., São Paulo, 1971.

Farjallat, Josë E.S. Desagregabilidade de rochas e problemas relativos ã sua aplicabilidade - Relato sobre o tema - 4⿳亠口冋- Semana Paulista de Geolo gia Aplicada, São Paulo, 1972.

Farjallat, Josẻ E.S., Tatamyia, Carlos T. E Yoshida, Riuiti. An experimental evaluation of rock weatherability. II Int. Congr. IAEG, São Paulo, 1974 . 
Farjallat, Josẻ E.S. Algunas implicaçóes tecnolỏgịcas de medịdas da permea bilidade ao ar: amostras confinadas e năo confinadas. X Seminärio Brasileiro de Grandes Barragens, Curitiba, 1975.

Ferro, J,G. de 0, Oliveira, J,E, de E Azevedo, L.C.R. de. Alguns tipos petrolögicos sedimentares da região de Sầo Luiz e seus usos como agregado em concreto de cimento Portland. Anais do 2\% Congresso Brasileiro de Geologia de Engenharia, vol. 2, São Paulo, 1978.

Folk, R.L. A review of grain size parameters. Sedimentology, 6:73-93, 1966.

Folk, R.L. \& Ward, W.C. Brazos river bar: A study in the significance of grain size parameters. Journal of Sed. Petrol., $27: 3-27,1957$.

Frangipani, Alcides. Mapa da superficie superior do basalto subjacente aos arenitos cretäceos no estado de São Paulo. Revista do Instituto Geogrä fico e Geolögico, no 67-72, 1961-1962.

Franklin, J.A. \& Chandra, R. The Slake durability test. Int. Journal of Rock Mechanics and Mining Sciences, vol. 9, pp. 325-341, 1972.

Franklin, J.A. Rock quality in relation to the quarrying and performance of rock construction materials. II Congresso International de Geologia de Engenharia, vol. I, São Paulo, 1974.

Freitas, Rui 0. de. Sedimentação, estratigrafia e tectônica da Sërie Bauru. Bol. F.F.C.L. U.S.P. ne 194, geol. ne 14: 185 pp., 1955.

Freitas, Rui 0. de. Geologia e petrologia da Formação Caiuá no Estado de São Paulo. Inst. Geogr. Geol. Bol. no $50: 122$ pp., 1973.

Fujimura, Fernando, Midéa, Nilson F., E Nieble, Carlos M. A influência do fenômeno da desagregação na resistência ao cisalhamento e compressibilidade de materiais basälticos granulares utilizados em barragens de enrocamento. 79 Seminärio Brasileiro de Grandes Barragens, Rio de Janeiro, 1971.

Fülfaro, Vicente J. E Suguio, Kenitiro. O Cenozóico Paulista: gênese e ida de. An. XXVIII Cong. Bras. Geol., Porto Alegre, 1974.

Fülfaro, Vicente J. E Suguio, Kenitiro. Problemas estratigráficos e evolução tectônica do Mesozóico da bacia sedimentar do Paranả. Noticias Geo morfolögicas, Campinas, 14 (27/28) : 113-116, 1974. 
Fumagalli, E. Test on cohesionless materials for rockfill dams. Journal of the Soll Mechanles and Foundations Division, vol. 95 NO, SM. 1.

Gidigasu, M.D. Laterite soil Engineering. Elsevier Scientific Publishing Co, 1976 .

Gitahy, Heraldo de S. O problema dos agregados para os concretos da barragem de Jupiã. Instituto de Pesquisas Tecnolögicas, São Paulo, 1963.

Golzê, A.R, Handbook of Dam Engineering, Van Nostrand Reinhold Company, 1977.

Gregs, S.A. \& Vergara, W. A ocorrência de arenitos interträpicos e rochas mistas na ärea de vulcanismo basältico do Rio Grande do Sul - ambiente de deposição, significado geotẻcnico e agrogeológico. An. 22 ? Cong. Bras. Geol., Belo Horizonte, 1968.

Guidicini, Guido, Geologia da barragem de lbitinga, rio Tietê, são Paulo. Cia. Hidrelêtrica do rio Pardo (CHERP), rel. interno, São Paulo, 1964.

Guidicini, Guido \& Campos, Jayme de 0 . Notas sobre a morfogênese de derrames basälticos. Bol. Soc. Bras. Geol., vol. 17, n: 1, São Paulo, 1968.

Guidicini, Guido \& Nieble, Carlos M. Estabilidade de taludes naturais e de escavação. Editora Edgard Blucher Ltda, Editora da Universidade de São Paulo, São Paulo, 1976.

Guidicini, Guido. Derrames secundärios em basaltos. Bol. Soc. Bras. Geol., vol. 19, ne 1, 1970.

Guidicini, Guido. Juntas horizontais de grande continuidade em derrames basälticos da bacia do Paranä. 20 Simpósio Regional de Geologia, Rio Claro, 1979.

Hamrol, A. A quantitative classification of the weathering and weatherabi lity of rocks. Proc, 5 th int. Cong. Soil Mech. and Foundation Engineering, vol. II, Paris, 1961.

Hasui, Yociteru, Hennies, Wildor \& Iwanucj, W. Idade do magmatismo bäsico Mesozöico do Brasil Central, In: Congresso Brasileiro de Geologia, 29\% Belo Horizonte, 1976. 
Hsu, J.C. Diretrizes para projeto e construção de barragens de terra e enrocamento. VIII Seminärio Brasileiro de Grandes Barragens, 1972.

Hypolito, R. \& Valarelli, J.V. Alteraçäo experimental de diabäsios. Anais 4⿳⺈ Sem. Paulista de Geologia Aplicada, São Paulo, 1972.

John, K.W. An approach to Rock Mechanics, Journal of the Soil Mechanics and Foundation Division, SM. 4, agosto 1962.

Kaji, N. Geologia da barragem de Promissão, rio Tietê, estado de São Paulo. An. Assoc. Paul. Geol. Aplic,, vol. 111, São Paulo, 1969.

Kanji, Milton A. Resistência ao cisalhamento de interfaces solo-rocha. 1a Sem. Paul. de Geol. Aplic,, vol. Ill, São Paulo, 1969.

Kanji, Milton A. Propriedades mecânicas dos materiais de transição. $V$ Con gresso Panamericano de Mecānica dos Solos e Engenharia de Fundações, Buenos Aires, 1975.

Kowalski, W.C. L'Influence des variations de teneur en eau sur la resisten ce mecanique et la deformation des roches dans la zone d'alteration. Bull. of the Intern. Assoc, of Engin. Geology, no 12, pp. 37-43, 1975.

Landim, Paulo M.B. \& Fülfaro, Vicente J, Notas sobre a gênese da Formação Caiuä. An, XXV Congr. Bras, Geol. 2: 277-280, 1971.

Landim, Paulo M.B., Soares, Paulo C., Fülfaro, Vicente J. Cenozoic deposits in South-Central Brazil and the Engineering geology. 2\% Congr. Intern. Geol, de Eng. Vol, 1 : $111-11.1,111-11.7,1974$.

Landim, Paulo M.B. E Soares, Paulo C. Estratigrafia da Formação Caiuä. An. XIX Congr. Bras. Geol, 1976.

Leal Gomes, M.J. Critërios de dimensionamento de ancoragens em escavações subterrâneas. Revista Geotecnia n? 25, Lisboa, 1979.

Leinz, V. Contribuição à geologia dos derrames basälticos no sul do Brasil. Bol. Fac. Fil. Ciências e Letras USP, n: 58, Geol, 5, São Paulo, 1949.

Leinz, V. et alli. Sobre o comportamento espacial do trap basältico da Bacia do Paranả. Bol. Soc. Bras. de Geologia, vol, 15 no 4, São Paulo, 1966. 
Leinz, V., Bartorelli, A. E Isotta, C,A, Contribuição do estudo magmätico basältico mesozöico da Bacia do Paranã. Anais da Academia Brasileira de Ciências, Rio de Janeiro, 40 (supl.) 167-81, 1968.

Leonards, G, A. Shearing resistance of granular soils, em Foundation Engineering. McGraw-Hill Book Company, 1962.

Leslie, D.D. Large-scale triaxial tests on gravelly soils. II Congresso Pa namericano de Mecânica dos Solos e Engenharia de Fundaçōes, vol. I, São Paulo, 1963.

Londe, P. The Mechanics of Rock Slopes and Foundations. Imperial College, Rock Mechanics Research Report, ne 17, Londres, 1972.

Louis, C. Etude des ëcoulements d'eau dans les roches fissurẻes e leurs in fluences sur la estabilitê des massifs rocheaux. Thèse, Karlsrwhe, 1968.

Maack, R. Algumas observações a respeito da existência e da extensão do arenito superior São Bento ou Caiuä no Estado do Paraná. Arq. Mus. Para nä 1: 107-129, 1941 .

Madureira, C.J. A utilização de cascalho de terraço na barragem de são simão. Revista Geotecnia, ne 20, Lisboa junho-julho, 1977.

Marques Filho, Pedro L, \& Levis, Paulo. Aspectos geolögicos de barragens de enrocamento com face de concreto. A experiência de Foz do Areia. 2 ? Congresso Brasileiro de Geologia de Engenharia, São Paulo, 1978.

Martines, $0 . C$. Sustentação e revestimento em tüneis e galerias. Tradução de artigo original apresentado pela revista da Association Française Des Travaux Souterrains, no 1, jan/fev/1974. Associação Brasilleira de Geologia de Engenharia, Tradução n: 10, 1980.

Marsal, R.J. Large scale testing of rockfill materials. Journal of the Soil Mechanics and Foundation Division, vol, 93, N0.SM.2, março 1967.

Marsal, R.J. Comportamento de suelos granulares. Curso Panamericano de Suelos, Depto. de Ing, de Suelos, Univ. Cat. Andrēs Bello, Caracas, 1967.

Marsal, R.J. Presas de Tierra y enrocamento. Editorial Limusa, Mëxico,1975. 
Martin, G, R. E Millar, P,J. Joint strength characteristics of a weathered rock. Proceedings of the thire Congress of International Society of Rock Mechanics-thimes 1-2, vol, 11, part A, pg. 241-247, Denver, 1974.

Mast, R.F. \& Potter, P.E. Sedimentary structures, sand shape fabrics, and permeability, pt, 2, Jour. Geology 71, 548-565, 1963.

Mello, V.F.B. de E Teixeira, A.H. Mecânica das Rochas. Escola de Engenharia de São Carlos, U.S.P.

Mello, Victor F.B. de. Recomendacōes referentes a estudos geolögicos e geotëcnicos para barragens. VIII Seminärio Nacional de Grandes Barragens, São Paulo, SP, 1972.

Mello, Victor F.B. de. Apreciações sobre a Engenharia de Solos aplicävel a solos residuais. $3^{\text {a }}$ Conferencia Sul Asiätica de Engenharia de Solos, Hong Kong. Trad. n? 9, Assoc. Bras. de Geol. de Eng., 1972.

Mello Mendes, Fernando de. Mecânica das Rochas. Instituto Superior Tëcnico, Lisboa, 1968.

Mezzalira, S. E Arruda, M.R. Observações geolögicas na região do Pontal do Paranapanema, Estado de São Paulo. An. Acad. Bras. Ciências, 37 (1) : 69-67, 1965 .

Mezzalira, S. Contribuição ao conhecimento da Estratigrafia e Paleontologia do arenito Bauru, Inst. Geogr, Geol. Bol. n? 51, 163 pp., 1974.

Midëa, Nilson F. Considerações sobre tëcnicas de ensaios de cisalhamento direto em enrocamento. Anais da $2 \stackrel{\text { a }}{\text { Semana Paulista de Geologia Aplica }}$ da, Vol. II, São Paulo, 1970.

Midëa, Nilson F., Fujimura, Fernando \& Paula, Luiz C, de. Observações sobre a necessidade de ensalos "in situ" para a caracterização da resistência ao cisalhamento de estruturas tipo junta, em derrames basäl ticos. 10\% Sem, Bras, de Grandes Barragens, Curitiba, 1975.

Minioli, B, Ponçano, W.L. \& Oliveira, S,M.B. Extensão geogrä́fica do vulcanismo basältico do Brasil Meridional. Anais da Academia Brasileira de Ciências, Rio de Janeiro, 43 (2) : 443-448, 1971,

Moler, W,A, E Cabrera, J,G. Caracteristicas de fundacöes sobre rochas ba-

- sälticas, Anais do 19 Cong. Bras, Geol. Eng. vol. 2, Rio de Janeiro. 1976. 
Moniz, A.C., Nascimento, A.C. E Paiva Neto, J.E: Mobilidade dos constituintes de rochas basảlticas de Säo Paulo durante o intemperismo. Revista Brasileira de Geociências, São Paulo, 3 (3) : 201-223, 1973.

Nascimento, UIpio. Oproblema da alterabilidade das rochas em Engenharia Civil. Laboratörio Nacional de Engeriharia Civil, Memöria no 363, Lisboa, 1970 .

Nogami, J.S. A tecnologia rodoviäria e as peculariedades dos nossos solos. 2: Congresso Brasileiro de Geologia de Engenharia da ABGE, São Paulo, novembro 1978 .

Oliveira, Antonio M.S. Aspectos geolögicos do derrame da barragem de Ilha Solteira, Rio Paranä. Anais do 1\% Sem. Paul. Geol. Eng., vol. 11, São Paulo, 1969.

Oliveira, Antonio M.S., Silva, Ricardo F. da E Guidicini, Guido. Comportamento hidrogeotécnico dos basaltos em fundações de barragens. Anais do 1: Cong. Bras. Geol. Eng., vol. 2, Rio de Janeiro, 1976.

Onodera, T., Yoshimaka, R. \& Noda, M. Weathering and its relation with mechanical properties of granite. Proceedings of the third Congress of the International Society for Rock Mechanics. Vol. II, part A, The mes 1-2, Denver, 1975.

Paraguassu, Antenor B. et alii. Arenito Botucatu como material de constru ção. Ciência e Cultura, São Paulo, 18 (2): 214.

Pettijohn, F.J., Potter, P.E. E Siever, R. Sand and sandsione. Springer-Verlag, 1972.

Pichler, E. Diques de arenito em Salto Grande, rio Paranapanema. Bol.Soc. Bras. Geol., vol. 1, ne 1, São Paulo, 1952.

Pichler, E. Rock characteristics of the basaltic formation of Maia FiIho dan site, Brazil. Proc. of the 6 th Congress on Large dams, New York, 1958.

Queiróz, Lincoln de A. Geotechnical Properties of Weathered Rock and Behavior of Furnas Rock Fill Dam. 8\% International Congress on Large Dams, Vol. 1, pp. 877-890. Edimburgh, England, 1964. 
Ramos, A.N, E Medeiros, R, A, Mapas de isöpacas e estruturas da Bacia Sedimentar do Paranä. Petrobräs, Rio de Janeiro, 1965.

Raymond, G.P., Gaskin, P.N., Davies, J.R. \& Van Dalen, K. Laboratory performance of railroad ballast, New Zealand Conference on Geomechanics, Ausiralian Geomechanics Society, pg. 238-242, Brisbane, 1975.

Roberts, A. Geotechnology - An Introductory Text for students and Enginetrs. Pergamon Press Ltd, , 1977.

Rocha, Maruel da, Mecânica das Rochas, Laboratörio Nacional de Engenharia Civil, Lisboa, 1971.

Rocha, Manuel da. Alguns problemas relativos à Mecânica das Rochas dos materiais de baixa resistência. Laboratörio Nacional de Engenharia Civil, memöria no 491, Lisboa, 1977.

Ruiz, Murillo D. Mecanismo de desagregação de rochas basälticas semi-alte radas. Anais do 2: Congresso Pan-Americano de Mecânica dos Solos e En genharia de Fundações, São Paulo, 1963.

Ruiz, Murillo D. Caracteristicas tecnolögicas de rochas do estado de São Paulo. Instituto de Pesquisas Tecnológicas do estado de São Paulo,bol. n! 50, São Paulo, 1966 ,

Ruiz, Murillo D., Camargo, Fernando, P., Midea, Nilson F. E Nieble, Carlos M. Some considerations regarding the shear strengh of rock masses.

Proc. Int. Symp, on Rock Mechanics, Madrid, 1968.

Ruiz, Murillo D. Problemas relacionados com a Geologia da barragem de Bar ra Bonita, rio Tietê, São Paulo. Instituto de Pesquisas Tecnológicas; Centrais Elêtricas de São Paulo, São Paulo, 1969.

Ruiz, Murillo D., Rë, Giäcomo, Celestino, T,B. E Buosi, C. Sintese das caracteristicas geomecânicas de macicos basälticos como fundações de barragens. 1 Cong. Bras, de Geol. de Eng., vol, 3, Rio de Janeiro. 1976.

Sartori, P.L., Maciel Filho, C. E Menegotto, E. Contribuição ao estudo das rochas vulcânicas de bacia do Paraná, na região de Santa Maria, RS. Revista Bras, de Geociências, vol. 5, n: 3, São Paulo, 1975. 
Schneider, A.W.V. Vulcanismo basältico da Bacla do Paranä. In: Congresso Brasileiro de Geologia, 24\%, Brasilia, 1970 .

Scorza, E. Consideraçoes sobre o arenito Cailuä. D, N, P, M. Bol. n: $139: 62$ pp, , 1952.

Sherard, J.L., Woodward, M.S., Gizlenski, M.S, \& Clevenger, B.S. Earth-Rock Dams. John Wiley \& Sons inc., 1963.

Soares, Paulo C., Landim, Paulo M.B. E Fülfaro, Vicente J. Avaliação preliminar da evolução geotectônica das bacias intracratônicas brasilleiras. An. XXVIII Cong. Bras, Geol, , 4: 61-84, 1974.

Soares, Paulo C. \& Landim, Paulo M.B. Depósitos Cenozöicos na região centro-sul do Brasil. Not. Geomorf. Campinas, 16 (31) : 17-39, 1976.

Soares, Paulo C. E Landim, Paulo M.B. Comparison between the tectonic evo lution of the inatracratonic and marginal basins in South Brazil. An. Acad. Bras. Ciênc. 48 (supl.) : 313-324, 1976.

Soares, Paulo C., Landim, Paulo M.B., Fülfaro, Vicente J. E Sobreiro Neto, Agostinho F. Ensajo de caracterização estratigräfica do cretáceo no Estado de São Paulo. 20 Simpósio Regional de Geologia, Rio Claro, 1979.

Souza, M.L.V. de. Mëtodo de projeto de pavimentos flexiveis. Departamento Nacional de Estradas de Rodagem, Rio de Janeiro, 1966.

Sowers, G.F. Engineering properties of residual soils derived from igneons and metamorfic rocks, 2\% Cong. Panam. Mec. Solos e Eng. Fund. (Brasil) vol. 1, pp. 39-62, 1963.

Spence, I.M., Ramsey, D.M. E Dhir, R.K. A Conspectus of Aggregate Strength and the Relevance of This Factor as the Basis for a physicial classification of crushed rock aggregate. Proceedings of the Third Congress of International Society of Rock Mechanics, thenies 1-2, vol. 11 , part A, pg, 71-78, Denver, 1974.

Stagg, K.G. \& Zienciewicz, 0.C. Rock Mechanics in Engineering Practice. John Wiley \& Sons, 1968.

Struillou, R. Prevision de l'alterabilité des materiaux employëes en gënie civil. Bull. Liaison lab, Routiers Ponts et Chaussës, n? 42, pp. $35-46,1969$. 
Suarez, J.M. Contribuição à geología do extremo oeste do estado de são Paulo. Tese de doutoramento apresentada à Faculdade de Filosofla, Ci ên cias e Letras de Presidente Prudente, 1973.

Sugulo, Kenitiro. Introdução à Sedimentologia. Editora Edgard Blucher Ltd. Editora da U,S.P. Säo Paulo, 1973.

Szëchy, K. Approximate Determination of Rock Pressure on Basis of a Statical Analogy. International Symposium of Rock Mechanics, of International Society of Rock Mechanics, Lisboa, 1966.

Terzaghi, K. Geologia aspects of soft ground tunneling, "Applied sedimentation", John Wiley \& Sons Inc., New York, 1950.

Terzaghi, K. Mecanismo dos escorregamentos de Terra. Traduzido por E. Pichler, Revista Politécnica, no 167, São Paulo, 1952.

Terzaghi, K. \& Peck, R. Soil Mechanics in Engineering Practice. John Wiley $\varepsilon$ Sons Inc., 1967.

Tourenc, C. Proprietes et Classification des Materiaux Naturels de Construction. Proceedings of the Second International Congress of the International Association of Engineering Geology, vol, 1, IV-GR-1 a IV-GR-35, São Paulo, 1974.

Utiyama, H. et al. Pavimentação econômica: Solo Arenoso Fino. Revista $D$. E.R., n: 124, Departamento de Estradas de Rodagem do Estado de São Paulo, São Paulo, 1977.

Vargas, Milton. Engineering propertis of residual soils from South Central Region of Brazil. II Congresso Internacional de Geologia de Engenharia, vol. 1, São Paulo, 1974.

Villibor, D.F., et al, Os Solos Arenosos Finos - Estado atual de sua utili zação em bases rodoviärias paulistas. Anais $V$ Congresso Brasileiro de Mecânica dos Solos e Engenharia de Fundação, São Paulo, 1974.

Yoshida, Riuiti. Contribuicão ao conhecimento de caracteristicas tecnolögicas de materiais rochosos. Tese de Doutoramento, Instituto de Geociências da USP, São Paulo, 1972.

Yoshida, Riuiti. Technology of natural construction materials. 11 Congres so Internacional de Geologia de Engenharia, vol. I, São Paulo, 1974. 
Washburne, C,W. Petroleum geology of the State of São Paulo, Brasil. Com. Geogräfica Geolögica Estado de São Paulo, Bol. 22, 282 pp., (1929), 1930.

Williams, W., Turner, F.J, \& Gilbert, C.M. Petrography. An. Introduction to the study of rocks in thin sections. Trad. para o portugues por Rui Ribeiro Franco, Ed. Poligono S.A., e Ed. da Universidade de São Paulo. 